\title{
LOCAL ENTREPRENEURIALISM, STATE RE-SCALING AND SCALAR STRATEGIES OF REPRESENTATION: \\ The Case of the City of Gaziantep, Turkey
}

\author{
by \\ Mustafa Kemal Bayırbağ
}

\author{
A thesis submitted to \\ The Faculty of Graduate Studies and Research \\ in partial fulfillment of \\ the requirements for the degree of \\ Doctor of Philosophy
}
School of Public Policy and Administration
Carleton University
Ottawa, Canada
February 2007
C Mustafa Kemal Bayırbağ




$\begin{array}{ll}\begin{array}{l}\text { Library and } \\ \text { Archives Canada }\end{array} & \begin{array}{l}\text { Bibliothèque et } \\ \text { Archives Canada }\end{array} \\ \begin{array}{l}\text { Published Heritage } \\ \text { Branch }\end{array} & \begin{array}{l}\text { Direction du } \\ \text { Patrimoine de l'édition }\end{array} \\ \begin{array}{l}\text { 395 Wellington Street } \\ \text { Ottawa ON K1A ON4 }\end{array} & \begin{array}{l}\text { 395, rue Wellington } \\ \text { Ottawa ON K1A ON4 } \\ \text { Canada }\end{array}\end{array}$

Your file Votre référence ISBN: 978-0-494-27088-2 Our file Notre référence ISBN: 978-0-494-27088-2

NOTICE:

The author has granted a nonexclusive license allowing Library and Archives Canada to reproduce, publish, archive, preserve, conserve, communicate to the public by telecommunication or on the Internet, loan, distribute and sell theses worldwide, for commercial or noncommercial purposes, in microform, paper, electronic and/or any other formats.

The author retains copyright ownership and moral rights in this thesis. Neither the thesis nor substantial extracts from it may be printed or otherwise reproduced without the author's permission.
AVIS:

L'auteur a accordé une licence non exclusive permettant à la Bibliothèque et Archives Canada de reproduire, publier, archiver, sauvegarder, conserver, transmettre au public par télécommunication ou par l'Internet, prêter, distribuer et vendre des thèses partout dans le monde, à des fins commerciales ou autres, sur support microforme, papier, électronique et/ou autres formats.

L'auteur conserve la propriété du droit d'auteur et des droits moraux qui protège cette thèse. $\mathrm{Ni}$ la thèse ni des extraits substantiels de celle-ci ne doivent être imprimés ou autrement reproduits sans son autorisation.
In compliance with the Canadian

Privacy Act some supporting forms may have been removed from this thesis.

While these forms may be included in the document page count, their removal does not represent any loss of content from the thesis.
Conformément à la loi canadienne sur la protection de la vie privée, quelques formulaires secondaires ont été enlevés de cette thèse.

Bien que ces formulaires aient inclus dans la pagination, il n'y aura aucun contenu manquant.

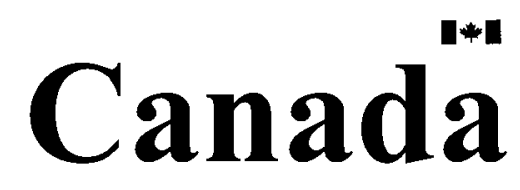




\begin{abstract}
This study examines the links between the recent rise of localities as significant and strategic loci of policy-making and the changing place of the capitalist state in political economy and its spatiality. The city of Gaziantep, located in the Southeastern part of Turkey, constitutes its empirical focus. Gaziantep started to industrialise rapidly from the 1980s onwards, a period during which neoliberal policy reforms began to be implemented in Turkey. This led many scholars and policy-makers to see Gaziantep, and similar cities called Anatolian Tigers, as a successful model of local entrepreneurialism, which replaced the state's active involvement in economic development.

Benefiting from the scale literature, urban regime theory, and studies on business associations, this study offers an alternative explanation, especially emphasizing the political dimension to local entrepreneurialism. Neil Brenner's conclusion, that entrepreneurial local governance is a medium and expression of the rescaling of the capitalist state constitutes the departure point. The thesis argues, however, Brenner's emphasis on the changing spatiality of the state has to be supplemented by investigating the emerging forms of representation of this re-scaled state. Thus, the concept "scalar strategies of representation" is introduced to examine in what ways the broader state re-scaling process contributes to the formation of local agency and how this agency influences the state re-scaling.

It is shown that the roots of the current local bourgeois activism go deeper into the Keynesian pre-1980 period. State re-scaling in Turkey during the post-1980 era, at best, facilitated the emergence of Gaziantep as an entrepreneurial city. The study also indicates that the growth in the local policy-making capacity comes about also as a result of scalar strategies of representation employed by the local business associations to overcome the obstacles to the local accumulation strategy posed by the national accumulation strategy and the associated state re-scaling. Here, the main concern of these business associations is not simply to bypass these obstacles. They, indeed, seek to re-shape and mould the scalar strategies of intervention and internal organisation of the state to their advantage, and thus are actively involved in the state re-scaling process as state-builders.
\end{abstract}




\section{ACKNOWLEDGEMENTS}

Dear Reader,

The work you are about to read is the product of a collective effort. Although I did the writing part (the reason for potential factual and theoretical errors or misunderstandings you might come up with), the peer review process I have gone through was a teaching one. The rich and insightful feedbacks I received from my thesis committee, and my dear colleagues from the Ottawa-Carleton Scale Reading Group, helped me to make it to this stage. For me it has been a process of growing up, as a scholar. Professor P. Rianne Mahon (my 'super'visor), Professor Fran Klodawsky and Professor Lisa Mills were my guiding light. My words would fail to express how much I appreciate the labour they have put into my thesis. Professor Mahon has been my guardian angel, my mentor. A true example to follow as a teacher, and a scholar!

Professor Neil Brenner served as the external examiner to this dissertation. His constructive and challenging review of this work will definitely set the path of my future studies. In fact, as an exciting scholar, he ignited the thinking process that eventually turned into this work. Professor Wallace Clement served as the internal examiner to my dissertation. His positive and encouraging comments will help me to build a more careful approach to the analytical categories I deal with. Professor Manfred Bienefeld made very helpful comments on the first two chapters and the introduction chapter of this study.

School of Public Policy and Administration, where I have always felt at home since day one, and the Faculty of Graduate Studies and Research, have been "very supportive" all the way, in every respect. Professor Donald Swartz and Professor Leslie Pal (graduate coordinators, for consecutive terms), and Iris Taylor (our wonderful graduate program secretary) were incredibly helpful during my studies in SPPA.

Department of Political Science and Public Administration, of Middle East Technical University (METU), and the Higher Education Council in Turkey provided me with a financial support that made it possible for me to concentrate on my work without worrying much about its financial aspects, during the first four years of my study. My colleagues from METU, and especially Professor Sinasi Aksoy and Professor Tarik Sengul were always there for me, whenever I needed their support.

And, I humbly kneel before those wonderful people, "my beautiful friends" (and you know who you are) and my beloved family, who made my life complete, and made me feel good about myself during the ups and downs of this dissertation writing process. 
They became my wings whenever I faced the storm. With their help, with the moral support they gave, I was able to turn the wind, which would otherwise take me down, to a magical force that pushed me to do my best.

One last word goes to my beloved Dilek; my wife, the source of my life, whose love and affection, whose beautiful smile has refreshed my soul, has rejuvenated my heart at every moment since the day we met. Whenever I fell down, she was right beside me to hold my hand, to put me back to work. She deserves the most of the credit for the energy that was put into this work. I sincerely dedicate this work to my precious Dilek. 


\section{TABLE OF CONTENTS}

INTRODUCTION

CHAPTER - I: "Theoretical Foundations" 13

$\begin{array}{ll}\text { Mainstream accounts } & 14\end{array}$

$\begin{array}{lr}\text { Contributions of the scale literature } & 20\end{array}$

Re-scaling of the capitalist state and the emergence of local 26 entrepreneurialism

The agency of capital and the changing face of local politics 40

Business associations, local politics and the state: Emergence of "scalar 54 strategies of representation"

$\begin{array}{ll}\text { Conclusion } & 65\end{array}$

$\begin{array}{lr}\text { CHAPTER - II: “The historical context” } & 68\end{array}$

$\begin{array}{ll}\text { In search of a national bourgeoisie (1923-1960) } & 71\end{array}$

The rise of planning ideology and the Import Substituting Industrialisation $\quad 91$ period (1960-1980)

Rise of neoliberalism and Gaziantep's bourgeoisie (the post-1980 era) $\quad 110$

$\begin{array}{ll}\text { Conclusion } & 117\end{array}$ 
CHAPTER - III: "The case of Gaziantep: Roots of Gaziantep's local entrepreneurialism"

Gaziantep: An examplary achievement of the new economic model?

The national accumulation strategy change, re-scaled forms of state intervention, and the roots of the current local bourgeoisie activism in Gaziantep

The state re-scaling, emphasised agency of local business associations, and 148 the birth of the scalar strategies of representation

Conclusion

CHAPTER - IV: "Gaziantep's Local Corporate Regime"

Political mobilisation of the local bourgeoisie

The role played by other key local actors in Gaziantep's corporate regime

Conclusion

CHAPTER - V: "The scalar strategies of representation: Institutional strategies"

The state bureaucracy

$\begin{array}{ll}\text { Political parties } & 216\end{array}$

$\begin{array}{ll}\text { The Prime Minister and the cabinet } & 221\end{array}$

$\begin{array}{ll}\text { The umbrella organisations } & 231\end{array}$

Discourses of re-scaling: Reterritorialisation of the "national" 237

$\begin{array}{ll}\text { Conclusion } & 241\end{array}$ 
CHAPTER - VI: "The scalar strategies of representation: Territorial strategies"

Gaziantep and Southeastern Anatolia: Regional policy of the state, regional policy of the local corporate regime, and the territorial strategies of representation

Gaziantep and the International actors: Jumping scales for 'compensation' and 'domination'

Gaziantep and other Anatolian Tigers: Re-making the historical-geography 281 of capitalist accumulation in Turkey

Conclusion

CONCLUSION

BIBLIOGRAPHY 


\section{LIST OF TABLES}

Table 2.1: Distribution of industrial enterprises in selected provinces (top 12

+ Adana, Ankara, Diyarbakır and Kayseri) according to the industrial census of 1927 (in a descending order).

Table 2.2: Changing geographical distribution of industrial enterprises employing >10 workers in Turkey between 1950 and 1963

Table 2.3: Central Governments in Turkey between 1960 and 1980

Table 3.1: Manufacturing workplaces established in Gaziantep since 1960s (firms of all sizes)

Table 3.2: Gaziantep's industrialisation process during the post-1980 period: The changing accumulation strategy

Table 3.3: The export structure of Gaziantep and Denizli as of the early $2000 \mathrm{~s}$

Table 3.4: Export incentives - distribution of the export incentives according to the firm's area of activity (legally defined)

Table 3.5: Number of KOBİ incentive certificates given by the KOSGEB

Table 3.6: Amount of KOBİ incentive per certificate (million Turkish Liras

Table 4.1: The industrial enterprises in Gaziantep and the membership 167 Structure of the GSO

Table 4.2: Pattern of Institutional Membership of the Executives of Industrial Enterprises in the GAP region

Table 5.1: Gaziantep's export and the export incentive certificates received by Gaziantep

Table 5.2: Changes in the government and the allocation pattern of state incentives to Gaziantep based firms 


\section{LIST OF ILLUSTRATIONS}

Schema 1.1: The diverse (and sometimes competing) logics of associability $\quad 56$

Map 2.1: The geographical regions in Turkey 76

$\begin{array}{ll}\text { Chart 3.1: Gaziantep's economy vs Turkish economy } & 123\end{array}$

Chart 3.2: Number of workplaces established in Gaziantep (employing >10 140 worker) from 1940 to 1996

Chart 3.3: Number of export incentive certificates and invesment incentive 141 certificates given to the firms in Gaziantep

Chart 3.4: Total amount of KOBİ incentive given by the KOSGEB in 146 selected, industrialised provinces

Schema 4.1: The (intra)organisational tensions that led to the emergence of 166 the GSO

Schema 4.2: The current institutional landscape of local business associations in Gaziantep

Chart 5.1. Comparison between the public investments received by the provinces of Gaziantep, Diyarbakır, Şanlıurfa (Gaziantep taken as basis)

Map 6.1: Anatolian Tigers and the uneven development in Turkey 


\section{GLOSSARY OF ABBREVIATIONS}

AKP

ANAP

AP

CHP

DEİK

DİE (now

TÜİK)

DP

DPT

DSO

DSP

DTP

DYP

EGEV

EGSD

EU

GAGEV
Adalet ve Kalkınma Partisi - the Justice and Development Party

Anavatan Partisi - the Motherland Party

Adalet Partisi - the Justice Party

Cumhuriyet Halk Partisi - the Republican People's Party

Dış Ekonomik İlişkiler Konseyi - the Council of Foreign Economic Relations

Devlet İstatistik Enstitüsü - the State Institute of Statistics (now) Türkiye İstatistik Kurumu - Turkish Statistical Institute

Demokrat Parti - the Democratic Party

Devlet Planlama Teşkilatı - the State Planning Organisation

Denizli Sanayi Odas1 - the Denizli Chamber of Industry

Demokratik Sol Parti - the Democratic Left Party

Demokrat Türkiye Partisi - the Democratic Turkey Party

Doğru Yol Partisi - the True Path Party

Ege Ekonomi Vakfı - the Aegean Economy Foundation

Ege Giyim Sanayicileri Derneği - the Aegean Clothing Manufacturers' Association

The European Union

Gaziantep Ekonomisini Geliştirme Vakfı - the Foundation for the Development of Gaziantep's Economy 


\begin{tabular}{|c|c|}
\hline GAGİAD & $\begin{array}{l}\text { Gaziantep Genç İşadamları Derneği - the Gaziantep Young } \\
\text { Businessmen's Association }\end{array}$ \\
\hline GAP & Güneydoğu Anadolu Projesi - the Southeastern Anatolia Project \\
\hline GAP-BKİ & $\begin{array}{l}\text { GAP Bölge Kalkınma İdaresi - the GAP Regional Development } \\
\text { Administration. }\end{array}$ \\
\hline GAPGİAD & $\begin{array}{l}\text { Gaziantep Paylaşımcı Genç İsadamları Derneği - the Gaziantep } \\
\text { Sharing Young Businessmen's Association }\end{array}$ \\
\hline $\begin{array}{l}\text { GAP- } \\
\text { GIDEM }\end{array}$ & $\begin{array}{l}\text { GAP Girişimci Destekleme Merkezi - the GAP Entrepreneur } \\
\text { Support Centre }\end{array}$ \\
\hline GATEM & $\begin{array}{l}\text { Gaziantep Ticaret ve Endüstri Merkezi - the Gaziantep Trade and } \\
\text { Industry Centre }\end{array}$ \\
\hline GAZÜ & Gaziantep Üniversitesi - Gaziantep University \\
\hline GESOB & $\begin{array}{l}\text { Gaziantep Esnaf ve Sanatkar Odaları Birliği - the Gaziantep Union } \\
\text { of Chambers of Petty Traders and Artisans }\end{array}$ \\
\hline GİADs & Genç İşadamları Dernekleri - Young Businessmen's Associations \\
\hline GIB & Güneydoğu İhracatçılar Birliği - the Southeast Exporters Union \\
\hline GSO & Gaziantep Sanayi Odas1 - the Gaziantep Chamber of Industry \\
\hline GTO & Gaziantep Ticaret Odası - the Gaziantep Chamber of Commerce \\
\hline GTSO & $\begin{array}{l}\text { Gaziantep Ticaret ve Sanayi Odas1 - the Gaziantep Chamber of } \\
\text { Commerce and Industry }\end{array}$ \\
\hline GTZ & $\begin{array}{l}\text { Alman Teknikl İşbirliği Kurumu - the German Technical } \\
\text { Collaboration Institution }\end{array}$ \\
\hline HÜRSİAD & $\begin{array}{l}\text { Hür Sanayici ve İşadamları Derneği - The Free Industrialists and } \\
\text { Businessmen's Association }\end{array}$ \\
\hline ICC & International Chamber of Commerce - ICC \\
\hline IM & Monetary Fun \\
\hline
\end{tabular}


İstanbul Sanayi Odası - the İstanbul Chamber of Industry

İTF Ittihat ve Terakki Fırkası - the Union and Progress Party

KOBİ Küçük ve Orta Boy İşletme - Small and Medium Enterprise

KOSGEB Küçük ve Orta Ölçekli Sanayi Geliştirme ve Destekleme İdaresi Başkanlığı - Small and Medium Industry Development Organization

KÖY Kalkınmada Öncelikli Yöreler programı - the "Areas Privileged in Development" program

MHP Milliyetçi Hareket Partisi - the Nationalist Action Party

MP Member of Parliament

MPM Milli Prodüktivite Merkezi - the National Productivity Centre

MSP Milli Selamet Partisi - the National Salvation Party

MÜSİAD Müstakil Sanayici ve İşadamları Derneği - Independent Industrialists and Businessmen's Association

OECD Organisation for Economic Co-operation and Development

OID Organised Industrial District

OSB Organize Sanayi Bölgesi - OID

RP Refah Partisi - the Welfare Party

SHP Sosyal Demokrat Halkçı Parti - the Social Democratic Populist Party

SİADs Sanayici ve İşadamları Dernekleri - Industrialists and Businessmen's Associations

SODEP Sosyal Demokrat Parti - the Social Democratic Party

TESK Türkiye Esnaf ve Sanatkarlar Konfederasyonu - The Confederation of Tradesmen and Artisans of Turkey 
TİSK Türkiye İşveren Sendikaları Konfederasyonu - The Confederation of Employers' Unions of Turkey

TOB (later Türkiye Odalar (ve Borsalar) Birliği - the Turkish Union of

TOBB) Chambers (and Stock Exchanges)

TSKB Türkiye Sanayi Kalkınma Bankası - the Turkish Industrial Development Bank

TÜRK-İŞ Türkiye İşçi Sendikaları Konfederasyonu - the Confederation of Turkish Trade Unions

TÜSİAD Türkiye Sanayici ve İşadamları Dernegi - the Industrialists' and Businessmen's Association of Turkey

UNDP The United Nations Development Program

UNESCO The United Nations Educational, Scientific and Cultural Organization

USA The United States of America

VAT Value Added Tax

WCF The World Chambers Federation 


\section{INTRODUCTION}

Since the mid-1980s, Turkey has witnessed the surge of a new wave of industrialisation spearheaded by a number of cities called the Anatolian Tigers. Cities such as Gaziantep, Denizli, Çorum, Kayseri and Konya rapidly industrialised during this period. This was reflected in the increasing number of small and medium sized industrial enterprises, the increased level of domestic and international exports, and a heightened "spirit of entrepreneurship". Their geographical distribution indicates that industrialisation in Turkey gained a new spatial momentum with the emergence of the Anatolian Tigers. The pre-1980 industrialisation in Turkey had been characterised by the concentration of industrial production and wealth in the İstanbul-centred Marmara region, and the İzmircentred Western Aegean region. With the rapid industrialisation of these cities, however, this geographical unevenness of economic development was challenged. Industrialisation began to spread across Anatolia, or Asia Minor, a term which is frequently employed to refer to the rest of the country versus İstanbul. ${ }^{1}$

The timing of this development coincided with a major shift in national economic policies, from the active pursuit of state-led industrialisation to neoliberalism. According to many policy-makers and scholars in Turkey, the Anatolian Tigers, thus,

\footnotetext{
${ }^{1}$ Of these cities, Gaziantep is located in Southeastern Anatolia, one of the most underdeveloped regions in Turkey. Others are located in Southern-Inner Anatolia (Kayseri, Konya), Northern-Inner Anatolia (Çorum) and Inner-Agean Region, or Western Anatolia, (Denizli).
} 
proved that neoliberal economic policies of the post-1980 era was a cure to the problem of uneven development, which had been poorly handled by the Keynesian policy interventions of the pre-1980 era. This has increased the popularity of the Anatolian Tigers, now seen as the successful examples of Turkey's new path of economic development. They have been widely hailed as living proof of how local entrepreneurship can achieve economic development, without the help of the state, within an increasingly 'free market' globally integrated economy.

The city of Gaziantep ${ }^{2}$ constituted one of the most remarkable examples, in this regard. Domestic politicians, national opinion leaders and big economic players even called Gaziantep the 'capital of the Anatolian Tigers'. The city's experience in industrialisation was seen as a model to be adopted by other cities in Turkey (including Anatolian Tigers like Denizli) and the national policy-makers. The significance attached to Gaziantep's experience was not simply due to the extent of its economic achievement. Indeed, cities like Kayseri and Denizli fared relatively better, or at least showed a similar degree of success. What is of interest to us here, and indeed the main reason why Gaziantep was labeled by some as a national model, is the way in which the economic development was handled by the entrepreneurs of Gaziantep, and their effectiveness in turning Gaziantep into an entrepreneurial city par excellence.

\footnotetext{
${ }^{2}$ With a population of 853,513 , Gaziantep is the largest metropolitan centre of Southeastern Anatolia, and functions as the economic centre of its region. The province of Gaziantep, whose administrative centre is the city of Gaziantep, houses the $7^{\text {th }}$ largest urban population in Turkey: $1,009,126$, with $78,52 \%$ urbanisation rate and an urban population growth rate of $3.125 \%$ (http://www.gaziantep.gov.tr/GAZIANTEP.php?page id=152). Gaziantep contributes to around $1.5 \%$ of the national GDP, and as of 2001, the income per capita of the province of Gaziantep is 1,593 US Dollars (The national average being 2,146 US Dollars in 2001) (http://ekutup.dpt.gov.tr/bolgesel/gosterge/1997$\underline{11 /}$.
} 
This study investigates the roots of this development within the context of the changing spatiality of the capitalist state and political-economy. The argument that is developed questions the neoliberal view that the Tigers' performance represents "spontaneous" local response to global market forces, as this ignores the critical role of state policies and of domestic political processes in the emergence of these success stories. The main axis of the debate in question is constructed around a binary opposition between the local and the national state, seen as two separate entities with alternative logics, and acting as alternative sites for policy-making and implementation. Neil Brenner offers an alternative, explaining the rise of these cities and regions as significant loci of policy-making in terms of the spatial re-scaling of the state linked to a shift in national accumulation strategy. What is missing in Brenner's approach is the role of local agency in re-scaling the state. My argument is that we also need to pay close attention to the political strategies pursued by the local bourgeoisie. More specifically, my thesis is that the rise of these cities and regions can be understood as the political re-inscription of changes in the balance of power within the bourgeoisie onto the spatial structure of the capitalist state. It argues that the agency of localities, increasingly manifested in the form of local entrepreneurialism, emerges through the political activism of a local bourgeoisie mobilised in support of a specific local accumulation strategy. In this respect, the formulation and implementation of such a strategy, within the context of state re-scaling, involves a challenge to the inter/intraclass balance of forces underpinning the existing national accumulation strategies. 
This research question and thesis will be explored in six chapters, whose content and outlines are given below:

\section{Chapter 1: Theoretical foundations}

The first chapter is devoted to the construction of a theoretical framework to identify the conceptual tools of analysis to be used in the thesis. Drawing especially on the literature of scale, the chapter starts with a critical analysis of the current accounts of the increasing political-economic significance of localities. It is suggested that Brenner's account of state re-scaling, which highlights spatial forms of intervention and internal organisation, provides a fruitful starting point to overcoming some of the shortcomings of previous analyses. It does not, however, address the ways in which local agency is involved in the re-scaling process. To deal with this problem, the chapter goes back to the theoretical roots of Brenner's analysis, drawing on Jessop's form analysis of the state, and focuses on spatial "form(s) of representation". For this purpose, the chapter introduces the concept of "scalar strategies of representation" as a key concept. Scalar strategies of representation are defined as discourses and strategies oriented to building contact and collaborations among actors and institutions operating at different scales, with the aim of developing interscalar arrangements favourable to the representers' interests and/or institutionalizing an improved access/power position. Thus, scalar strategies of representation pursued by local actors not only serve to transmit their demands to existing interlocutors. They are also adopted to establish new mechanisms to coordinate and link re-scaled sites of decision-making, while drawing new 
interlocutors into the local and national political economy, thus re-producing the "capitalist state as a condensed form of re-scaled social/class relations" (cf. Poulantzas 1978). To understand the emergence of local entrepreneurialism as an expression of local agency, the chapter investigates the changing place of the bourgeoisie in local politics, and discusses how its concerns are translated into a local agenda through the creation of a local corporate regime, a concept which refers to governance arrangements created under the local bourgeoisie's leadership. Finally, to make sense of the motives behind this political mobilisation of the local bourgeoisie, and to appreciate the dynamics influencing their agenda formation - to be pursued through scalar strategies of representation, the chapter examines the role of business associations as representatives of the bourgeoisie. The chapter identifies two axes of tensions that determine the mobilisation agenda of of these associations: the one between the logic of membership (their needs and demands) and the logic of influence (the priorities and expectations of the interlocutors); and the one between the logic of implementation (service provision) and the logic of goal formation (determination and promotion of the association's agenda).

\section{Chapter 2: The historical context}

This chapter provides the historical context for Gaziantep's industrialisation, paying special attention to the way in which the relations between the state and bourgeoisie evolved in Turkey since the establishment of the republic. The main argument is that the history of the Turkish bourgeoisie can not be understood separately from the history 
of the state. In this respect, the current re-scaling of the (nation) state implies critical changes in the nature of the Turkish bourgeoisie and the way it has engaged with the state. The birth of politically conscious local bourgeoisies needs to be understood in this context. The chapter introduces the key institutions and developments that have shaped the political mobilisation of Turkey's local bourgeoisies. It deals with four key issues: a) the historico-geographical roots of the bourgeoisie in Turkey; b) the changing forms of political representation of the bourgeoisie; c) changing relations amongst different fractions of the bourgeoisie; and d) capital accumulation strategies followed by the Turkish state, with particular emphasis on industrialisation. These issues are examined by concentrating on three important historic phases of the Turkish political economy: the periods of $1923-1960,1960-1980$, and 1980-present. The chapter indicates that the roots of the (political) local bourgeois activism, i.e, the driving force behind current local entrepreneurialism, can be traced back to intra-bourgeoisie struggles of the 19601980 period. Once the story of (local) business associations in Turkey is taken into account, the chapter indicates, it becomes rather difficult to explain the rise of local entrepreneurialism in Turkey as the product of a neoliberal rupture, or as the product of a grand-scale transformation set in motion by a post-Keynesian state.

\section{Chapter 3: The case of Gaziantep: Roots of Gaziantep's local entrepreneurialism}

This chapter makes the case for Gaziantep as the empirical focus of this study, by outlining the national policy significance of Gaziantep's experience, and the dynamics of its economic development especially during the post-1980 period. Then, the chapter 
proceeds to examine how the changing national accumulation strategy and the associated re-scaling of the state intervention and its internal organisation facilitated the agency of local business associations, and the birth of the scalar strategies of representation. In particular, it is shown that decentralisation of policy-making and implementation powers to the local governments; promotion of a general pro-business political atmosphere in the country; and the opening up of the domestic and local economies through introduction of an export-oriented economic policy and the associated support schemes, enhanced the local policy-making capacity during the post1980 period. Yet, the chapter suggests that the state re-scaling process also introduced a number of obstacles to the local business associations' pursuit of an industry-oriented accumulation strategy in Gaziantep. In particular, the changes in the forms and channels of representation preferred by the government, and the political-economic instabilities of the 1990 s, constituted these negative stimuli. As the following chapters indicate, these latter developments played a more important role in the political mobilisation of the local bourgeoisie in Gaziantep. Finally, the chapter concludes that there is a need to concentrate on local political processes if one is to understand how local bourgeois activism transformed into local entrepreneurialism in relation to the national accumulation strategy shift and the associated state re-scaling.

\section{Chapter 4: Gaziantep's Local Corporate Regime}

This chapter builds upon the research focus suggested by the preceding chapter. The aim of this chapter is to describe how local agency and scalar strategies of political 
representation were formed around the current local accumulation strategy. The focus is, therefore, on local politics. The chapter concentrates on the mobilisation of the local bourgeoisie through the construction of a local corporate regime. The institutional dynamics of this mobilisation is examined by focusing on the case of the business associations in Gaziantep. In particular, the chapter indicates that the split of the older Gaziantep Chamber of Commerce and Industry marked the watershed in the construction of the local corporate regime. It is shown that the post-1980 shift in the national accumulation regime contributed to this development by accelerating the industrialisation in Gaziantep, thereby giving birth to a stronger and self-conscious industrial bourgeoisie there. In other words, the logics of membership and goal formation made their weight felt in the intra- and inter-organisational dynamics of local business associations. This was especially the case with the younger Gaziantep Chamber of Industry (GSO), which began to determine the local political agenda, and the private business associations, which, in fact, emerged in the 1990 s to provide the local bourgeoisie with fresh venues for political mobilisation and improved representational capacity. The Gaziantep Chamber of Commerce (GTO) functioned as a source of cohesion in the business community, and the cross-membership between GTO and GSO considerably contributed to this. The chapter indicates that the agenda of the local corporate regime was shaped by a concern to support a multi-scalar local accumulation strategy, and to protect the local political concensus around the local corporate regime. The local corporate regime was based on active cooperation between the GSO, the GTO, the Greater Gaziantep Municipality, the Governor's office and the 
local media. The unstable political-economic atmosphere of the 1990s, and the changing political opportunity structure for the representation of local business interests, the chapter argues, compelled the local corporate regime to develop scalar strategies of representation to pursue a pro-industry local agenda.

\section{Chapter 5: Scalar strategies of representation: Institutional strategies}

This chapter explores the scalar strategies of representation that target the nerve centres of the integral state where the national scale is (re)produced and decisions shaping the national political-economy are taken. It examines how the re-scaling of the intervention schemes and internal organisation of the state affected the agenda of Gaziantep's corporate regime. It concentrates on four institutional locales, namely the state bureaucracy, political parties, the Prime Minister and the Cabinet, and the umbrella organisations of the business associations, as sites and/or channels of representation. The section on the state bureaucracy gives an account of the expectations of the local entrepreneurs from the state. Here, the state bureaucracy is not taken as an interlocutor, but as an instrument of policy implementation. The chapter also discusses the role of political parties, as a significant channel of representation in a parliamentary regime, and indicates that such traditional channels of representation can remain insufficient in a re-scaled and centralised policy-making process. The chapter underlines the significance of the Prime Minister and the Cabinet as the major target of representation strategies, especially with the re-scaling of the decision-making powers during the post1980 era. It is shown that Gaziantep was quite successful in getting state benefits and 
investments, and thus it is suggested that the motto of 'succeeding without the help of the (national) state' is an unwarranted one. The presence of Gaziantep-oriented MPs in the Cabinet made the decisive difference. Yet, Gaziantep's success in getting state benefits and investments was also the product of an organised effort and lobbying undertaken by Gaziantep's corporate regime and the MPs, who succeeded in challenging very definition of national interest, through construction of Gaziantep's image as a national champion. In this regard, the umbrella organisations of the business associations constituted the key site of representation, and the GSO and the GTO have worked hard to capture the leadership of these organisations, and eventually became successful. This endeavour of the local corporate leaders also supports the conclusion that, while the state re-scaling forces the local actors to develop new forms of representation, it also alters the significance of available channels of representation. Nonetheless, the chapter also indicates that party-political concerns can make a major come-back any time, especially during the current single party rule of the AKP (Adalet ve Kalkınma Partisi - the Justice and Development Party), which can insert tensions into the local corporate regime, subsuming certain local interests into the party's broader agenda, and thus increasing the weight of the logic of influence for Gaziantep's local business associations and the local corporate regime.

\section{Chapter 6: Scalar strategies of representation: Territorial strategies}

The chapter looks at territorial strategies of representation pursued by Gaziantep's corporate regime. The main concern of these strategies is to increase the bargaining 
power of the local corporate regime in their dealings with the national state and their region, and to sustain an increasingly multi-scalar local accumulation strategy. These strategies have targeted three scales: the regional scale, the supra/international and/or global scale, and the national scale. An important point to make here is that the corporate regime does not employ territorial re-scaling strategies to find an alternative to the national state. To the contrary, these strategies are pursued to strengthen the corporate regime's representation at these various scales, and were also employed to shape the re-scaling process of the state. For instance, the local corporate regime worked hard to develop strong relations with the EU, and did this by promoting a national project, that of integrating Turkey into the EU. Thus, they effectively turned Gaziantep into a site of experimentation where an early round of state re-scaling takes place as part of a nationally pursued state re-scaling agenda. In the case of Southeastern Anatolia, there was a similar attempt to influence the state re-scaling process. The local corporate regime's strategy was not restricted to getting the lion's share of the shortterm benefits distributed by the state in the region. There was a broader aim of transforming the local-national relations in the region which can effect long-term changes in the regional policies of the state in the favour of Gaziantep, especially by locating the city at the top of an inter-local hierarchy in the region. Establishment of political-economic alliances with other Anatolian Tigers was another important strategy, in this regard. This strategy came as part of an attempt to challenge the position of İstanbul, and the İstanbul-based large scale capital, as the national hegemon, which enjoys the monopoly of access to the global political-economy and strongly 
influences the priorities of the state's economic policies. The chapter, however, also notes that this alliance-building strategy can face serious obstacles given the fact that certain Anatolian Tigers compete for the same markets. Finally, the chapter suggests that local corporate regimes established around a political-economic re-scaling agenda, pursued through both institutional and territorial strategies, are much more fragile than those whose focus is merely local. This is mainly because the scalar strategies of representation employed by the regime, and thus the economic re-scaling strategy, led to the fragmentation of the local bourgeoisie on the basis of their differing levels of spatial mobility, and imported a number of non-local actors and political-economic dynamics to Gaziantep's political economy, thereby threatening the power balance that underlied the local corporate regime. 


\section{CHAPTER - I}

\section{"Theoretical Foundations"}

This chapter outlines the theoretical framework. It starts with a critical summary of existing mainstream accounts of the increasing significance of cities and regions as new loci of policy-making. This section emphasizes the need to locate the growing policy significance of localities within a broader spatio-temporal context. This allows one to link the rise of localities to the changing spatiality of the capitalist state in Turkey. Section two focuses attention on the potential contribution of the "scale" literature, and especially on Neil Brenner's work, which sees the rise of cities and regions as an expression of the current spatial re-scaling of the capitalist state. Section three moves to incorporate agency into Brenner's framework. For this purpose I turn to Bob Jessop's form analysis of the state, and emphasise the need to concentrate on "forms of representation". In this regard, the concept of "scalar strategies of representation" forms a key concept for investigating the links between the current re-scaling of the capitalist state and the rise of cities and regions. To indicate how the scalar strategies of representation are shaped and become operational, the last two sections reflect on the changing role of the bourgeoisie in local politics, the institutional form of local entrepreneurialism, and the role played by (local) business associations as strategic sites and agents of the bourgeoisie's interest representation. 


\section{Mainstream Accounts}

In the existing literature, we can identify two competing accounts of the changing relations between the state and localities, both of which are based on the same conception of the state as an entity made up of a number of formal institutions and organisations, with the capacity to act on its society and economy. Thus understood, the state has its own separate existence and logic, behaving as a strategising actor. Here, the term "state" actually refers to the nation state, not the "capitalist state". The first approach argues that national borders have lost their significance and the nation state's policy-making capacity has been eroded by the increasing volume and pace of global capital flows, the globalisation of market relations and of production. According to this interpretation, the nation state has become largely redundant with regard to the regulation of social and economic affairs, and cities and regions emerge as substitutes for the declining nation state, acting as the facilitators and engines of a more global economy (Ohmae 1995). In contrast, the other view claims that the nation state is as strong as ever. The globalisation process - and the altered role of cities and regions in the changing system of economic relations - is a product of the conscious strategies of the (nation) states as autonomous actors standing above society and economy (Weiss

\footnotetext{
3 In fact, the term "capitalist state" denotes a specific form of state that belongs to a specific social formation. Its political, institutional and spatial logic is shaped by the "capitalist social formation" it is "embedded into". The ontological independence designated to the state in these views however, deny us the possibility of establishing of this connection.
} 
1998; cf. Skocpol 1986). From this perspective, the rise of cities and regions is understood as the product of conscious strategies designed and implemented by nation states in response to changing (global) economic conditions.

The recent literature on urban and regional studies ${ }^{4}$ avoids macro explanations based on dualistic analyses of the sort described above, while elaborating empirically grounded explanations of why and how localities have become prominent sites and agents of economic coordination and policy-making. ${ }^{5}$ In these studies, the spatial, technological and organisational restructuring of industrial production process remains a central concern, explored using such concepts as "flexible production", "postfordism" etc. From this perspective cities and regions are understood to constitute a new spatial framework of capitalist production and accumulation that has been transformed by changing technologies of production (Cooke 1997; Cooke and Morgan 1998; Hirst 1993; Piore and Sabel 1984). ${ }^{6}$

\footnotetext{
${ }^{4}$ The following set of studies provide a good example of the literature: Amin and Thrift (1999); Barnes (1999); Cooke (1997); Cooke and Morgan (1998); Gertler (1999); Storper (1999); Wolfe (1997, 2002); Hirst (1993); Putnam (1993); Sabel (1990); Piore (1990); Storper (1990); Storper and Walker (1989); Piore and Sabel (1984); Holbrook and Wolfe (2002). A number of authors such as Lovering (1999), MacLeod and Goodwin (1999), MacLeod (2001), Leibowitz (2003), and Jonas and Ward (2004) provide us with an extensive and critical analysis of the main features of this "new orthodoxy", if we are to borrow Lovering's term.

${ }^{5}$ The literature is enriched by the insights of different disciplines such as economic-sociology of the newinstitutionalist school, the regulation school (divergence/convergence theses), industrial-relations, political science, more generic studies looking at the impacts of the "process of globalisation", ethnicity studies, and to a lesser degree, geopolitics and international relations.

${ }^{6}$ Here, we should note that a number of studies, concentrating on new modes of industrial production and regional innovation, do not restrict their analyses to local and/or regional scale. Authors like Gertler and Wolfe (Gertler 1992; Wolfe and Gertler 2001; Wolfe and Gertler 2002) problematise the relation and interactions between the nation state, national policy regimes and institutional structures (including national innovation regimes), and the emerging regional dynamism (as in the case of regional innovation regimes). Such studies examine the ways in which various policy schemes and sectoral policies
} 
Regions have historically accumulated unique socio-cultural capacities, captured by such notions as 'social capital' (Putnam 1993), 'trust' (Putnam 2000; Fukuyama 1995), 'institutional thickness' (Amin and Thrift 1999), 'untraded interdependencies' (Storper 1999). These are widely seen as the source of their strength in accommodating the challenges posed by the current re-structuring process of industrial production. At times, these can lead to "superior forms of coordination of production increasing the competitiveness of the regions" (cf. Soskice 1999; Wood 2000). In this framework, the "firm" appears as the most significant social actor and its agency becomes the centre of attention. Firms' interactions, their engagements with the global production networks, and their internal dynamics, are brought into the spot-light. Factors such as social capital and institutional thickness are thus seen as factors potentially conducive to the success of 'local firms'. Concepts like (firm) network(s) and regional clusters are also critical in making sense of this new logic of industrial production. Yet, the concept of network, as generally employed by these approaches, is not of much help in allowing us to understand how these changing production relations interact with the organisational and political forms of the rising local entrepreneurialism (cf. Goodwin and Painter $1996,644)$ that constitutes a vital driving force behind this transformation.

It is important to examine the socio-political framework within which localities come to acquire the power of agency. The new mainstream literature deals with this issue by focusing on local socio-economic particularities, expressed in notions such as

implemented by the national state - including education, training, R\&D, regional development policies, etc - influence the regional innovation process. 
"social capital" and "community". The success stories of certain regions like Emilia Romagna and Baden-Württenberg ${ }^{7}$ have been depicted as examples of the possibility of "social cohesion within market economy." Here, community is introduced not only as a new ontological category of economic analysis - other than the individual or the firmbut also as a political entity. ${ }^{8}$ Such accounts are based on the "civil capacity of regions to take care of themselves", i.e, their capacity to act independently from the state. ${ }^{9}$ According to this view, localities can provide an alternative to "hierarchy", i.e, bureaucracy, and "market", as forms of economic and political coordination. The local provides a natural middle ground, a "third way" between competition and cooperation, as a form of coordination across different local agents, transforming them into a coherent and cohesive supra actor (Hirst 1993; for a critical analysis see Şengül 2001; and Güler 2003). ${ }^{10}$

\footnotetext{
${ }^{7}$ Harvie (1994) provides a nice short description of such city-regions, in the case of Europe.

8 This economic model has been supported by an intellectual re-interpretation of the meaning of "economy", linking the "economic" to the "social", by defining economy as an act of the community, thus incorporating the notion of "cooperation" to the defition of economy along with the notion of competition (see Polanyi [1957] 1992).

9 Emphasis on the notions like social capital, trust, and institutional thickness tells us that regional success, to a great extent, depends on endogenous factors/policy inputs, which cannot be imported from somewhere else, and whose formation would take decades, even centuries. Then, despite the best intentions, it might prove to be difficult to employ the models of associative governance (cf. Bradford 1998; Leibowitz 2003; Geddes 2000, 797; cf. Jones and Ward 2002; cf. Eisenschitz and Gough 1996) imported from successful examples to initiate regional economic development or to improve social cohesion.

${ }^{10}$ Such an understanding of the state also sees the rise of localities as the triumph of civil society over the state, designating this phenomenon a normative value. See Amin and Robins' (1990) critique of Piore and Sabel (1984) as well as MacLeod (2001)'s discussion on Lovering (1999).
} 
In this framework, the notion of "governance" is employed to describe the new dynamics of local politics and policy-making. The term refers to "self-organizing, interorganizational networks [where there is a] significant degree of autonomy from the state. Networks are not accountable to the state; they are self-organizing. Although the state does not occupy a priviliged, sovereign position, it can indirectly and imperfectly steer networks" (Rhodes 2000, 346, emphasis original). In particular, governance stands for close collaboration between the private (business) sector, the public (national/local state) sector and the voluntary sector (Rhodes 2000, 346; Harvey [1989] 2001; Şengül 2001, 53; Mayer 1995; cf. Jones and Ward 2002, 19; Martin et al. 2003). Such collaboration is not institutionalised, but exists rather as a process (Şengül 2001; Güler 2003). Thus understood, the notion of governance indicates how the boundaries of the state as a social relation are redefined. Yet, as Lowndes and Wilson (2001) note, the questions of how, and through what mechanisms, a community translates into a collaborative policy environment and increased policy-making capacity, remain unanswered. We still need to know how different local actors join forces to establish their locality as an autonomous decision maker, while still pursuing their own particular interests. Moreover, as Goodwin and Painter indicate, "the concept of 'localness' is itself problematic. Geographical spaces, irrespective of size and scale, are far from homogeneous. There is rarely, if ever, a unified 'local interest' in politics, even if the term is a frequent rhetorical figure in political discourse" $(1996,637)$.

There is thus a need for a closer look at the local political processes behind the rise of local entrepreneurialism, set in relation to the changes in the broader political- 
economic context (cf. Painter 1998, 265). In fact, the empirical research on single case studies lead to a preoccupation with the local, even in the urban regime literature concentrating on dimensions of local politics (Lauria 1997). As MacLeod argues, this literature displays "a reluctance to place regional change within a wider political economy that is increasingly characterised by fiscal restraint and welfare retrenchment"11 (2001, 805). This effectively leaves external factors ${ }^{12}$ largely out of the picture. As Painter and Goodwin suggest,

The new local governance involves more power being exercised by a very varied range of institutions which operate at a range of spatial scales. At one extreme there are institutions which operate, at least in part, at a spatial scale lower than that of elected local government; examples include 'self-governing' schools and some voluntary organizations. By contrast, at the 'highest' spatial scale, global corporations may play a role in local governance by, for example, obtaining financial concessions associated with inward investment or negotiating a customized curriculum for workforce training with a local educational institution $(1996,636-637)$.

In addition, the processes or forces which influence changing production relations and the course of socio-economic development of a locality, including those existing prior to the rise of local entrepreneurialism, have to be taken into account if we

\footnotetext{
${ }^{11}$ Indeed, Hirst (1993) touches upon the issues of welfare state and welfare entrenchment, yet does not much focus on the relation between this re-entrenchment and the rise of the region as the new core of economic development.

${ }^{12}$ Here, the term external is used provisionally. As we shall see later, the arguments elaborated in this study rely upon a dialectical view of space elaborated by authors like David Harvey (1996, Chapter 2). Also see Peet (1998, 98-99). The dialectical approach sees external and internal as two instances of spatial dynamics of capitalism; capitalism which tends to create and destroy simultaneously. The ontological distinction between internal and external would presume the existence of cities and regions as 'things' independent from the social and economic processes they are embedded into in the real world. This is, obviously, a claim that my study is critical of.
} 
are to make sense of the increasing policy significance of cities and regions. As Ward and Jonas suggest, "much of the actual struggles around the scalar reorganisation of capitalism, competition, and the state do involve and indeed cannot easily avoid substantive relations of connection between pregiven places, spaces, and scales in the state, not least being those of the 'city', 'region', and 'nation' " $(2004,2126)$. The uneven nature of the capitalist accumulation process (Soja 1985; Harvey 1985; Duncan and Goodwin 1988; Smith 1991), the nation state's involvement in the creation and management of those differences ${ }^{13}$, and the political dynamics behind these processes have to move to the centre of our discussion. And here the recent literature on spatial "scale" offers fruitful insights that can be of help while addressing these issues.

\section{Contributions of the scale literature}

The scale literature aims at understanding the spatial construction of social relations. It attempts to see how these relations are constructed and challenged at different spatial scales (from the global, to the national, to the regional, to the local, to the community, to the family etc), and how those relations find their expression in socio-spatial forms. Three different, yet interrelated, concerns run through this literature:

1) Scale as a means for knowledge production and abstraction: (scale as an analytical category: epistemological and methodological concerns) (Smith 1992, 75; Miller

${ }^{13}$ See Amin and Robins' (1990) critique of Piore and Sabel (1984). 
1994; 1997; Delaney and Leitner 1997; Jones 1997; Peck 2002, 340-341; Harvey [1989] 2001, 351; Brenner 2001; Paasi 2004).

2) Scale as the product and site of (political-economic) decision-making: (scale as an operational category: structure-centred analysis) (Jessop 2000, 355; Swyngedouw 1997a; 1997b; Brenner 1999; 2000; 2001; Collinge 1999; Taylor 1982; cf. Hadjimichalis and Vaiou 1990, 21-22; cf. Mayer 1995)

3) Scale as a (political-economic) strategy: (scale as an operational category: agencycentred analysis) (Smith 1996; Rousseau 2000; Masson 2005; 2006; Agnew 1997; Jenson 1995; Şengül 2001; Cox 1998; Mahon 2003; Swyngedouw 1997a, 147; Herod 1997; Herod and Wright 2002b; Marston 2000; Marston and Smith 2001 vs Brenner 2001; McCann 2003, 162).

The first set of studies approach the concept of scale as a means for knowledge production and abstraction, and conceive objects, processes, and actors established at a certain spatial scale in relation to those established at other scales (Mahon and Keil 2006). Instead of dividing social reality into ontologically fixed spatial objects or layers of territory, it recognises the complexity of political-economic processes by referring to the interactions between structures and actors established at different spatial scales. Scale as "a produced societal metric .... differentiates space" (Marston and Smith 2001, 615), and as 'a means of abstraction' renders complex empirical processes theoretically visible (Paasi 2004, 539). In other words, the notion of scale offers a meaningful comprehensive picture that can be employed to explain seemingly unique, particular events (cf. Peck 2002, 340). Thus, a scalar approach can help us locate the question of 
local political-economy in relation to the broader processes of capitalist re-structuring (cf. Harvey [1989] 2001, 351), and therefore to comprehend 'local (political-economy)' as the site and end-result of the relations, tensions, conflicts and compromises between different actors and structures constituted at different spatial scales (McDowell 2001, 229; cf. Hadjimichalis 1987). It also helps to escape dichotomies such as 'local versus global' or 'local versus national' that posit these different instances of politicaleconomy as competing ontological categories ${ }^{14}$ (cf. Peck and Tickell 2002, 383).

The second set of studies employ a structure-centred perspective which defines 'scales' as 'socio-spatial products and sites of political-economic decision-making'. Here the notion of 're-scaling' is central and refers to a shift of power, resources and authority between different scales of political-economy. Allen introduces an important caveat, however, regarding the conceptualisation of power and re-scaling. Power, is not something "more or less exchanged intact between scales" $(2004,22)$. On the contrary, power becomes visible when the boundaries are re-drawn in terms of the inclusion/exclusion of various actors to a decision-making process (at the local scale or national scale). Thus authors employing the notion of scale 'as a site of decisionmaking' caution that any re-scaling of sites of political-economic decision making goes hand in hand with a re-definition of the boundaries between the state and civil society (Jessop 2000; cf. 1997; Swyngedouw 1997a; 1997b; cf. Mayer 1995; Hadjimichalis and Vaiou 1990, 21-22). Thus, in the neoliberal context, which privileges capital's priorities

\footnotetext{
${ }^{14}$ or worse, identifying local with the concrete and the global with the abstract, thus offering locality as a the prioritised scale of analysis, while the nature of the global left untouched, or just assumed away.
} 
and promotes the state's active collaboration with capital, local bourgeoisie's organisational connections with the state assume special importance. In other words, neoliberal state re-scaling re-arranges institutional mechanisms of inclusion/exclusion of various social classes and groups, and thus effective forms of representation, thereby altering their access to sites of decision making - mainly to the advantage of the bourgeoisie.

As Mahon and Keil argue "Rather than assuming set dimensions of social reality and the structuring of the human condition, scales are socially produced and reproduced through myriad, sometimes purposeful, sometimes erratic social, economic, political and cultural actions" (2006, 5). Social and political structures once established at different scales are constantly (re)produced and challenged by various actors. They are not ontological givens (Dicken et al. 2001; cf. Herod and Wright 2002a, 11; Peck 2002, 340; cf. Amin 2002), but are actively produced and reproduced by the political actions of various actors, local and non-local. In this regard, neither globalisation nor re-scaling of the state can be seen as an automatic response to certain external factors. The redrawing of the boundaries between the state and civil society - in other words, the passage from 'government' to 'governance' is not an automatic outcome of "uncontrollable supralocal transformations, such as globalization, the financialization of capital, the erosion of the national state, and the intensification of interspatial competition" (Brenner and Theodore 2002, 341, emphasis original). Instead, the rise of cities and regions as political-economic actors must be understood as a matter of local 
political mobilisation, which produces an uneven geography of state re-scaling. As Hamel et al suggest,

Globalization processes lead to uneven rescaling of municipal and regional governments, because each case is unique in many ways as waves of neoliberalization are met by iverse activity of accommodation and resistance in the urban region. .... Rescaled policy-making capacities and the development of a collective actor at the city-regional scale are developed not only through institutional building, but also in relationship with social and economic mobilization $(2006,35)$.

In this regard, the rise of cities and regions is not a universal phenomenon to be explained by 'models', but is rather a product of agency (Cabus 2001). ${ }^{15}$ It occurs when local actors are able to manage their relations with the nation state, and with other nonlocal actors, so as to establish the locality as an actor and a scale of decision-making. This involves political struggle that necessarily cuts across more than one scale of political-economy, effectively stretching the boundaries of local governance towards non-local scales. As McGuirk notes,

Conceiving of urban governance as part of a wider system of political-economic interdependencies requires a multiscalar perspective. Such a perspective needs to be cognizant of the operation of social processes across scales and of the dynamic, co-constituting relations between scales. In other words, it requires a relational view of scale that understands the scalar organization of governance as an outcome of scale politics (2003, 203-204).

\footnotetext{
15 In the cases of Birmingham and Sheffield (England) and Detroit (Michigan, USA), Digaetano and Lawless $(1999,569)$ indicate that large scale economic transformations do not produce homogenous responses in terms of the emergent form of urban governance. In other words, responses of different cities to common experiences originating from neoliberal oriented policy reforms can be fundamentally different.
} 
The agency centred approach makes an important contribution in understanding the dynamics of "scale politics", by identifying various spatial strategies of local political-economic actors. In particular, the concept of 'jumping scales' (Smith 1992; Rousseau 2000) refers to situations in which political-economic actors constituted at a certain scale establish contact with actors from other scales: a) to find new allies for cooperation; b) to escape competition and/or control; c) to stretch (cf. Whatmore and Thorne 1997$)^{16}$ their spatial reach of influence; d) to legitimise certain politicaleconomic claims; and e) to form and mobilise a new collective political actor. In other words, political actors may respond to the threat of exclusion by jumping scales through establishing partnerships with actors operating at other scales, by re-defining the discourse of the struggle, thereby inviting other actors into the arena of struggle to give them the upper hand (Rousseau 2000). Such scalar strategies of representation, by altering the scalar reach of the actors both shape and reflect the political strength and identity of the actors (Swyngedouw 1997a, 168; cf. Genieys 2004). Thus, if we are to understand the process through which localities emerge as actors, it becomes crucial to examine the scalar strategies that various local actors have pursued as they formulate their own particular interests as the local interest.

In the proposed framework of analysis, local political-economic actors, then, can be understood as 'mindful, embedded boundary-spanners' negotiating the thin line between what is internal and what is external (cf. Crouch and Farrell 2002) including

\footnotetext{
16 Although Whatmore and Thorne reject the notion of scale (as a hierarchical construct) their understanding of "stretching" relations comes close to the use of "scale" as a strategy.
} 
the boundaries between the state and civil society. Thus, while the second strand of the scale literature shows the re-scaling of the capitalist state to involve a re-drawing of the boundaries between the state and civil society, the agency centred perspective focuses on the conflictual nature of this process, which involves challenging the power balances between established political-economic actors that were condensed into the spatiality and temporality of the capitalist nation state (Poulantzas 1978; Mahon 1984). Hence, to

explain how the increasing prominence of localities as strategic loci and actors of policy-making is related to the re-scaling process of the capitalist state, it is necessary to investigate the interest representation strategies pursued by the local actors who come to challenge power balances that were crystallised in the spatiality of the pre-existing capitalist state. These actors will inevitably include those with a keen interest in the establisment of their locality as an entrepreneurial actor, especially including certain fractions of the local bourgeoisie.

\section{Re-scaling of the capitalist state and the emergence of local entrepreneurialism}

Neil Brenner's account of the scalar transformation of the capitalist state's spatiality sheds light on the conditions for the emergence of localities as significant loci and agents of policy-making. Brenner (1999) defines cities and the state as "forms of territorial organisation", and argues that 
processes of reterritorialisation - the reconfiguration and re-scaling of forms of territorial organisation such as cities and states - constitute an intrinsic moment of the current round of globalisation. ... The territorial organisation of contemporary urban spaces and state institutions must be viewed at once as a presupposition, a medium and an outcome of this highly conflictual dynamic of global spatial restructuring $(1999,431)$.

Following Brenner, the rise of cities and regions can be understood as part of the same process that transforms the spatial logic of the state. In New State Spaces (2004), Brenner elaborates on this insight by adopting Jessop's (1990) strategic-relational approach to identify "state spatial projects" and "state spatial strategies" that are then used to illuminate the dynamics behind the emergence of local entrepreneurialism across Western Europe. "State spatial projects" produce the "state space in narrow sense"17 and "state spatial strategies" generate the "state space in integral sense". Especially important for this analysis is Brenner's emphasis on the "state space in integral sense" which problematises how the institutional and regulatory re-structuring of the capitalist state intermingles with the corresponding social and economic transformations triggered by changing capitalist accumulation processes.

This "integral" understanding, based on the spatial strategies of the state, involves the coupling of two parallel processes, the transformation of the capitalist accumulation processes and the evolution of the state form. Here, Brenner makes a striking observation: the rise of cities and regions as the new strategic scales and actors of capitalist accumulation is in fact part and parcel of the re-scaling of the capitalist

\footnotetext{
${ }^{17}$ State spatial strategies refer to the institutional re-scaling of the state, especially de-centralisation of the state structure, and the mechanisms introduced to provide the internal coherence of the re-scaled state structure.
} 
state. Cities and regions serve as the arena of the current re-scaling of the state, which is a product of the transition from spatial Keynasianism to the Competitive state, inscribing new spatial selectivities onto the fabric of urbanisation and accumulation processes. This line of argument, backed by an extensive empirical survey of the changing pattern of Western Europe's urban / regional fabric, makes three essential contributions to our discussion:

a) Brenner's analysis shows that the "disappearance of the national" state has to do with a strategy shift on the part of the capitalist state, which denounced the Keynesian concern to intervene in every corner of its territory, with the aim of achieving spatial equity. Rules and regulations are defined and implemented in local terms, based on the strategic selectivies of the state (Brenner 2004, 172). Thus, Brenner's analysis goes beyond the simplistic interpretations equating the rise of cities and regions with the nation state's loss of power.

b) By challenging the empirical focus of studies which tend to concentrate exclusively on local dynamics, Brenner's framework encourages us to investigate the links between the emergence of urban regimes or growth coalitions (in the case of Western Europe) and the macro (non-local) processes:

the proliferation of entrepreneurial approaches to urban governance represents a key expression and outcome of the place- and scale-specific types of state spatial projects and state spatial strategies that have been mobilized by postKeynesian competition states. As such, entrepreneurial urban policies have been closely intertwined with contemporary processes of state rescaling (Brenner 2004, 177, emphases added). 
c) Brenner's argument, that "urban governance has served as a major catalyst, medium, and arena of state rescaling processes" (2004, 174), brings urban governance to the centre of attention. As a result of this, the epistemological focus of the investigation is redefined, thus giving us a chance to problematise the local "political" processes in relation to the re-scaling of the state:

the increasingly widespread demand for place-specific regulatory, institutional, and infrastructural arrangements is to be interpreted less as the reflection of inexorable economic requirements than as the expression of newly emergent political strategies intended to position particular subnational economic spaces within supranational circuits of capital accumulation $(2004,166$, emphasis original).

To sum up, state spatial projects and state spatial strategies are two key analytical categories that can be used to analyse the rise of localities as new sites of regulation and decision making. State spatial projects can be understood as schemes designed and implemented by central governments to further rationalise the capitalist state's politico-institutitonal and legal structure in order to better monitor the changing capital accumulation processes. In this regard, the decentralisation of policy-making capacities and resources to local governments and the establishment of new placespecific governance structures like regional development agencies can be understood as instances of spatial state projects seeking to facilitate new state strategies, shaped by the post-Keynesian concerns regarding the "competitive state" (Brenner 2004). State spatial strategies thus involve the introduction of locational strategies that are more selective and prudent in distribution of state resources, increasingly on the basis of 
inter-local competition. As we will later see, the post-1980 state benefit schemes in Turkey reflected a similar pattern of change in the state intervention.

These new state spatial projects encourage local interests, especially the local bourgeoisie, to play a more active role in the policy process by institutionalising their traditionally informal participation in local politics. Selective resource distribution schemes, as part of these new state spatial strategies, have provided further incentives for those local interests to mobilise in order to represent their interests as localities better. Thus, Brenner's framework captures the context which influences the emerging "political strategies intended to position particular subnational economic spaces within supranational circuits of capital accumulation" $(2004,166)$. But, there is still another brick to put on top of this theoretical edifice. Although Brenner alludes to the role of political strategies in the rise of local entrepreneurialism, and recognises that "the role of diverse social forces ... in shaping state spatial projects and state spatial strategies, as well as the ways in which the resultant configurations of state spatial organization in turn mold the geographies of territorial alliance formation, sociopolitical mobilization, and contention" $(2004,112)$ should constitute one of the future research questions, these concerns remain unexplored in his book. An important analytical challenge that has to be met in dealing with this research question is to establish the analytical link between the broader changes Brenner examines in his book and the rising local agency. At this point, Brenner's framework has to be re-constructed, because, according to Brenner, 
the variation of state spatial selectivities cannot be explained entirely with reference to the divergent political agendas and geographical orientations of the various social forces acting in and through the state. For such agendas and orientations have in turn been circumscribed within certain determinate institutional parameters associated with (a) the distinctively territorial form of statehood under modern capitalism; and (b) the endemic problem of regulating uneven spatial development within a capitalist space-economy $(2004,95)$.

Once the problem is defined in this way, we see the actors and the structures as ontologically separate pillars of analysis, in which structures shape and limit the behaviour of social actors. Moreover, the state's spatial projects and strategies appear largely as moments of the current structural transformation of the capitalist accumulation process and its regulation. Thus, the rise of local entrepreneurialism appears as an unavoidable local reaction to, and consequence of, these broader structural changes. There remains, however, a need to investigate: a) how these forces affect the process that leads to greater local agency; b) how they shape the resulting political strategies; and c) the ways in which these local interests are ultimately integrated into the spatiality of the reconfigured state.

To address this problem it is necessary to go back to Jessop's form analysis of the state, on which Brenner (2004) draws his analytical framework. While Jessop (1990) identifies 'form(s) of representation', 'form(s) of intervention', and 'form(s) of internal organisation' as three facets of the 'state as form', Brenner deals only with the last two of these. His notion of "state spatial projects" stands for "spatial forms of internal organisation", while his "state spatial strategies" correspond with "spatial forms of intervention". What still needs to be elaborated is the "spatial forms of 
representation" to show how the agency of cities and regions is linked to, and interact with, the changing spatiality of the capitalist state (Bayırbağ 2005). This thesis will develop the term "scalar strategies of representation" to examine the spatial forms of representation, and to refer to the strategies that different local and non-local actors adopt as they seek to promote and inscribe their own interests into the changing spatiality of the capitalist state.

The formation of agency can not be considered or understood independently of the interests that promote the formation and mobilisation of a newly assertive particular political-economic agent at the local scale. As Jessop argues, "Interests are not pregiven but must be defined within the context of specific accumulation strategies" (1990, 160). While Brenner's account of the current state re-scaling is built with reference to a broader accumulation strategy shift (from the Keynesian Welfare State to the Competitive State), the implications of this contextual change for the forms of representation do not receive enough attention. Yet, as Jessop notes,

the changing imperatives of capital accumulation in the field of intervention entail changing requirements in the field of representation. ... a reorganization of this balance [between capital and labour] may become a prerequisite to restoring the conditions favourable to accumulation. Changes in the articulation of different state apparatuses, in the organization of access to such apparatuses, in the forms of political mobilization, in the character of state intervention and in political strategies and political alliances can prove significant in this respect $(1990,122)$.

Accordingly, this thesis argues that the "scalar strategies of representation" adopted by various local groups must be understood if one is to operationalise the 
concepts of "state spatial projects and strategies" by looking at how they materialise through new dynamics of local governance. But, what is the contribution of this emphasis on "scalar" strategies of representation? It is not a new way of describing a pre-existing empirical phenomenon which simply adds a spatial dimension to it by explaining the forms of representation from a scalar perspective. The importance of this new perspective can be understood only in light of certain empirically constituted and observable changes in the role and place of the capitalist state in political-economy. In this regard, Jessop highlights three developments,

[1] A dialectic of de-territorialization and re-territorialization of specific powers in the political system, hence a reshaping of national states qua mutually exclusive, formally sovereign, spatially segmented instantiations of the Westphalian order, the transfer of powers previously located at this territorial level upwards, downwards or sideways, and the allocation of new powers to different scales; [2] A dialectic of de-statization and re-statization as the internal demarcation within the institutional ensemble of political power is redefined and activities are reallocated across this division; ... [3] A reordering of political hierarchies associated with the relativization of scale ... - with implications for the restructuring of international relations, domestic relations and the interrelations between them $(2000,351)$.

In fact, in State Theory, Jessop is explicitly concerned with the form of the nation state, and the forms of representation he focuses on in his book - parliamentarism, corporatism and clientelism - are those whose sole target is the nation state, as the only institutional site where 'interlocutors' for a mobilised social group could be found. His later work, however, and especially his above emphasis on 'de-territorialization and reterritorialization of specific powers in the political system', 'de-statization and restatization', and 're-ordering of political hierarchies' suggest that the re-scaling process 
of the capitalist state has diversified the potential interlocutors for a mobilised social group, in scalar and institutional terms. Thus, we should expect to see the emergence of new (scalar) forms of political representation.

In this study, political representation will be defined as 'the sum of strategies and discourses developed by political-economic actors to promote the interests of certain social groups in relation to those interlocutors who are in a position to influence the conditions of capitalist accumulation, distribution and re-distribution'. The ultimate goal of these representational efforts is to develop new interscalar arrangements favourable to the representer's interests and to institutionalize their (enhanced) access/power position.

In this framework, an 'interlocutor' is an institution and/or agent to which mobilised groups look because they possess the authority and (financial and/or organisational) capacity to achieve the groups' interests. An interlocutor could contribute to the cause of a mobilised group in three ways: a) by direct provision of the financial and/or organisational resources sought by the group; b) by lifting legal and/or other obstacles currently blocking the demands of a mobilised group, sometimes by legitimising these demands via legislation or other forms of explicit political support; c) or by linking up with the mobilised group in the pursuit of mutual interests that could be better achieved via active cooperation.

Interlocutors no longer reside only within the institutional boundaries of the national state. As a result, national parliaments, national political parties, and the personal networks surrounding national political figures no longer necessarily constitute 
the most significant interlocutors. In Turkey, the policy significance of these various institutional sites of representation has changed over time, especially with the gradual centralisation of decision-making power within government - in the Prime Minister's or the top executive's hands - to facilitate the process of neoliberal transformation. These changes have compelled social actors, intent on pursuing their interests, a) to seek out new interlocutors capable of meeting their demands, or helping them to raise those demands before the multiplicity of decision-making centres; b) to search for new mechanisms such as long-term partnerships with state and non-state actors, whose territorial foci are strectched across different spatial scales.

Beyond these considerations, scalar strategies of representation, as distinct from traditional representation strategies, refer to different social actors' efforts to re-organise and to coordinate emerging sites and schemes of policy-making so as to render them more favourable to their interests. As Jessop puts it "as new scales and temporalities emerge and/or existing ones gain in institutional thickness, social forces also tend to develop new mechanisms to link or coordinate them" (Jessop 2002, 99). Scalar strategies of representation can thus be understood as instruments for shaping, coordinating and linking newly emerging structures, re-producing the "capitalist state as a condensed form of re-scaled social/class relations" that can no longer be constituted solely within the spatio-temporal matrix of the nation state (cf. Poulantzas 1978). Another important contribution of "scalar strategies of representation" has to do with Jessop's insight that the form of representation has an important bearing on the process of interest definition, since an emphasis on scalar aspects of the interest representation 
process also reminds us that the variables taken into account by the social actors have become diversified, thus rendering the process of interest formulation a more delicate task. Moreover, these actors can improve their bargaining position considerably by pursuing scalar strategies of representation. Expansion of the interlocutor portfolio and the increasing availability of resources to meet their demands make these actors less dependent on the priorities and constraints set by their traditional interlocutors, helping them bolden their claims.

If we are to understand how the scalar strategies of representation pursued by local actors articulate with the re-scaling of the capitalist state,

a) first, we need to look at what kind of scalar strategies of representation are developed to influence and constrain the evolving state spatial strategies. Here, in particular, we are talking about the establishment of new ties with politicaleconomic actors at other scales, which expand the portfolio of financial and organisational resources that can be used to stimulate local economic development. Such strategies also serve to strengthen the bargaining power of local actors vis a vis the national government by locating particular local interests at the core of re-scaled state strategies. Similarly, localities can attempt to by-pass existing (national) territorial distribution schemes that serve against the interests of the locality, while seeking to promote the particular city's or region's place within a wider network, or hierarchy of, localities, thereby re-framing the territorial focus of state spatial strategies and projects. Therefore, by pursuing scalar strategies of representation local actors aim at re-defining the territorial basis of coalition building and 
searching for new interlocutors and/or sites of interest representation. We will call these strategies "territorial strategies of representation".

b) Second, we need to investigate representation strategies pursued intra-nationally in response to internal changes in the organisation of the state, namely "institutional strategies of representation". Here, various institutions and authorities which make up the state apparatus constitute the target of these strategies. Their main concern is to control or to capture the re-scaled sites of decision-making, and to establish new channels of communication with them in order to gain more influence in shaping the priorities of state spatial strategies and projects. In effect, this involves a redefinition of the meaning of "national", "regional" and "local", but does not necessarily imply the formulation of new coherent state projects or strategies. At this point, we have to note that these strategies also contribute towards re-definition of the territorial framework of state spatial strategies and projects, thus complementing territorial strategies of representation pursued by local actors.

We will elaborate on these two strategies in the remainder of this chapter. Before we proceed, however, we need to discuss the forms of representation and how the re-scaling process of the state has transformed their significance in the case of Turkey. As noted earlier, Jessop highlights three important forms of representation: clientelism, corporatism and parliamentarism. He compares these in terms of their strategic selectivity, i.e, how well they contribute to the articulation of particular interests and reproduction of capital; and how well they protect an accumulation strategy from the potential disruptions caused by anti-capitalist concerns. While all 
three forms have self-destructive features, Jessop argues that parliamentarism constitutes a superior form of representation since it separates policy-making from implementation, thereby ensuring the continuity of state strategies and policies even in times of political crisis due to intra/inter-class conflicts. In parliamentarism,

Any advantages accruing to capital must be found in the legitimating effects that might stem from a popular mandate for a government whose activities are otherwise restrained by 'business interests as functional constraints' and/or in the individuating or at least pluralizing impact of citizenship on dominated classes. Beyond this the advantages of parliamentary representation for capital depend on the nature of parties elected to office $(1990,165-166)$.

In Turkey, as we shall see in Chapter 2, the pre-1980 period was characterised by numerous failed attempts to establish a corporatist policy-making structure ${ }^{18}$, starting in the 1960 s and ending with an explosion of intra-bourgeois struggles. These struggles changed the picture of party politics in Turkey by further fragmenting the party system and contributing to the birth of the coalition governments of the 1970s. These developments produced a policy paralysis which resulted in the Coup d'Etat of 1980, thereby confirming Jessop's concerns about the deep problems with corporatism as a form of representation. The post- 1980 period witnessed the launching of a new state

\footnotetext{
${ }^{18}$ Here, let me quote the classic definition of corporatism as a system of interest intermediation, as given by Philippe Schmitter: "Corporatism can be defined as a system of interest representation in which the constituent units are organized into a limited number of singular, compulsory, noncompetitive, hierarchically ordered and functionally differentiated categories, recognized or licensed (if not created) by the state and granted a deliberate representational monopoly within their respective categories in exchange for observing certain controls on their selection of leaders and articulation of demands and supports" (1974, 93-94). For additional discussion on corporatist theory see Schmitter and Grote (1997).
} 
project and strategy that has brought parliamentarism and clientelism ${ }^{19}$ to the fore as dominant forms of representation, especially for the bourgeoisie. Thus the strong oneparty governments of the early 1980s fostered a clientelistic form of representation and encouraged individual members of the bourgeoisie to get directly involved in party politics, through the pro-business Motherland party which mainly represented big capital. Yet, this clientelism soon lost ground with the onset of serious financial and economic crises, partly resulting from the economic policies of the Motherland Government. Parliamentarism re-gained importance in the 1990s, but the resulting shaky coalition governments led the bourgeoisie to distance itself from party politics, once more in favour of a more careful approach towards the political parties. Thus, political parties (including their local branches) lost significance as sites of representation. In a context characterised by the centralisation of national decisionmaking power, the local bourgeoisie was compelled to find alternative channels of representation and access to the cabinet and the prime minister. An important scalar strategy of representation thus emerged was to capture control of the national umbrella organisations of local business associations as these offered more direct access to the government.

${ }^{19}$ According to Lemarchand and Legg, "Political clientelism ... may be viewed as a more or less personalized, affective and reciprocal relationship between actors, or sets of actors, commanding unequal resources and involving mutually beneficial transactions that have political ramifications beyond the immediate sphere of dyadic relationships" $(1972,151-152)$. 
The agency of capital and the changing face of local politics

In order to understand local actors' scalar strategies of representation we also need to investigate how these strategies are formulated, and by whom. As McCann observes,

The reconfiguration of urban governance in recent decades has, among other things, entailed a reshuffling of the locations of power among the institutions of the state, capital, and civil society and the opening up of the urban policymaking process. An important aspect of this has been capital's increased degree of direct control over the formulation of urban policy $(2003,159)$.

In other words, the re-scaling of the state deeply affected and transformed the nature of local politics, re-drawing the boundary between the state and civil society in favour of business interests and emphasising the role of capital as a political agent. Thus it becomes necessary to understand how capital turns into a political agent, and, in particular, how the changing interest definition of capital triggered by a national accumulation strategy shift is reflected upon the forms of strategies adopted by capital.

Again, Jessop's framework is of help in developing the argument. According to Jessop, the interest of capital in general can be defined at an abstract level as sustenance of the circuit of capital, in "the reproduction of the value-form along with its various conditions of existence such as law, money and state" (1990). At the same time, Jessop also draws our attention to the tensions between "capital in general" and "particular capitals": 
since capital in general is not an economic agency, it cannot represent its own interests. This can only be accomplished through particular capitals whose interests happen to coincide with those of capital in general and/or through representative organs which attempt to articulate these interests and defend them against particular capitals whose interests happen to be inconsistent therewith ... In the present context, analyses of capitalist organisations often reduce the problem of representation to one of how accurately they represent the economic interests of capital in the political system. This ignores two crucial difficulties. Interests are not pre-given but must be defined within the context of specific accumulation strategies. In addition the means of representation affect the definition of economic interests and are not merely passive or neutral channels for relaying these interests. ... This involves the question of state form and state power $(1990,155,160$, emphasis added).

Once we reject the idea that 'capital in general' is an agent, then we can explain the interactions and tensions between certain state policies (meaning the state spatial strategies and projects formulated around "different strategies of accumulation" such as export-oriented regimes or import-substituting industrialisation strategies) and the immediate needs/short term interests of certain fractions of the bourgeoisie. Second, once we recognise the heterogeneity of capitalist interests, then we can start to look for empirical instances of how that heterogeneity becomes visible in the political sphere.

Yet, there is also the question of interest formation. While Jessop's emphasis on form(s) of representation offers some insight, it is not enough to rely on broad categorisations like parliamentarism, corporatism, etc. We have to investigate by whom the interests are defined and defended, in what institutional/organisational form, and by what means. In this context it is crucial to evaluate the role of business organisations. King suggests that capital can employ three different modes of collective action: a) the "firm itself"; b) "informal cooperation"; c) the "business association". Of these options, 
the first one - i.e, that of individually responding to, and seizing upon, the constraints and opportunities that the market offers - appears to be the politically safer option (1983, 110-111). Yet, King continues, "If it is accepted that organised political representation is a less preferred source of influence for capital than individual action in the market, this suggests that formal association occur when economic power is weakened and is no longer sufficient for controlling the political process" $(1983,111)$.

King thus offers a good way to start unpacking the research problem set by Jessop's observations. ${ }^{20}$ As we shall see, the fact that organisations can influence the ways in which collective interests are defined, supports Jessop's above conclusion that "the means of representation affect the definition of economic interests and are not merely passive or neutral channels for relaying these interests". From this perspective, we can see business organisations as a means of representation, being established in response to the threat of losing power, or of being excluded from the policy-making process (also see Langille 1987, 46-47; Silva and Durand 1998; Carroll and Shaw 2001, 196-197).

David Harvey's account of local politics in the context of the spatial dynamics of accumulation processes ${ }^{21}$ provides a good basis for understanding the role of business associations. Here, Harvey puts the question of locality at the centre of

\footnotetext{
${ }^{20}$ Ironically, the tendency of the new orthodoxy in urban and regional studies is to narrow the focus to the first two modes of collective action: the firm's behaviour and the role played by local specificities, such as regions' socio-cultural capacities, captured by the notions as 'social capital' (Putnam 1993), 'trust' (Putnam 2000; Fukuyama 1995), and 'untraded interdependencies' (Storper 1999), rather than to this third mode of collective action we are concerned with.

${ }^{21}$ (1985, 125-164; [1989] 2001, Chapter 16).
} 
capitalist accumulation via his concept of 'structured coherence'. Capitalist production and consumption processes tend to form a territorially defined structured coherence, within which the local economy and social relations can be reproduced and sustained. According to Harvey,

This structured coherence ... embraces the forms and technologies of production ... the technologies, quantities, and qualities of consumption ...., patterns of labor demand and supply ... and of physical and social infrastructures ... The territory within which this structured coherence prevails is loosely defined as that space within which capital can circulate without the limits of profit within sociallynecessary turnover time being exceeded by the cost and time of movement (Harvey [1985] 2001, 328).

In an increasingly global, and neoliberal, economy, the need to protect this structured coherence is emphasised. Here, local politics appear as a site of the geopolitical defence of such "structured coherences" within the context of the creative destruction that is so characteristic of capitalism, and that tends to destroy the very landscapes it has once created to make way for new landscapes of accumulation. In this struggle local actors try, through class alliances, to sustain/defend existing spatial fixes (also see Duncan and Goodwin 1988; cf. Cox 1998) that were constituted by certain social/physical infrastructures reflecting some technology of production. In this context, the local bourgeoisie's concern with the sustainability of local accumulation process places an important responsibility on the shoulders of local business associations in developing a collective, coordinated and pro-business effort to maintain this stability, and compels them to be more actively involved in local politics. 
Changes in local politics thus should not be understood simply as a reaction to something happening "outside", nor can local politics and local governance structures be defined simply in terms of its functionality at the national level (cf. Cockburn 1977). Rather, changes in the dynamics of local governance need to be understood as part of the shift in capitalist accumulation from a Fordist-Keynesian Regime to one of 'flexible accumulation' ([1989] 2001, 348) ${ }^{22}$ in which local governance is forced to change while also shaping the new regime through local actors' response. And that response will be largely shaped by the nature of the urban coalitions that emerge in this context. As Harvey reminds us, "Within a metropolitan region as a whole, we have to look to the formation of coalition politics, to class alliance formation as the basis for any kind of urban entrepreneurialism" ([1989] 2001, 351, emphasis added) where entrepreneurialism is a code for local activism within a more competitive environment.

The actors that are likely to be more active in this process of alliance formation are those who held power and those who have a lot to lose from the dissolution of the pre-existing structured coherence. ${ }^{23}$ Yet, we should note that alliance formation is not only about conservation of the status quo. It is also a part of the local actors' search for (new) alternatives to the existing local agendas of capitalist accumulation. For Harvey,

\footnotetext{
${ }^{22}$ Brenner (2004) builds upon this observation to explain the role of cities and regions in the passage from spatial Keynesianism (and its corresponding Fordist regime of accumulation) to Locational policies (and its corresponding Post-Fordist regime of accumulation).

${ }^{23}$ Of course, the organisational capacity of those potential actors will be critically important for their ability to mobilise. Some social groups will be unable to respond constructively to such changes, even though they might be the ones who will suffer most.
} 
Each coalition will seek out its distinctive version of what Jessop (1983) calls 'accumulation strategies and hegemonic projects'. From the standpoint of longrun capital accumulation, it is essential that different paths and different packages of political, social, and entrepreneurial endeavours get explored. Only in this way is it possible for a dynamic and revolutionary social system, such as capitalism, to discover new forms and modes of social and political regulation suited to new forms and paths of capital accumulation ([1989] 2001, 366, emphasis added).

To reiterate, 'local coalition' is a key concept for analysing the rising activism of the local bourgeoisie in the context of the re-scaling of the capitalist state. Yet, formation of a local coalition is not an automatic response to broader capitalist regime shifts. To better understand how local actors, and particularly the local bourgeoisie, mobilise to protect a pre-existing local accumulation strategy, or to formulate and implement a new one, we need to examine local politics and coalition building. Castells makes an important observation, in this regard: "Sometimes it is through city politics that substantial changes are produced in the power relationships between classes. ... [and] ...Municipal and regional politics, as institutional expression of urban policy, is becoming one of the major axes of the political confrontation of classes in advanced capitalism" $(1978,175,179)$. Hence in analysing the experience of particular places, it is necessary to pay close attention to how compromises are reached between different groups and (fractions of) classes at the local scale.

The urban regime (U.R.) literature offers a number of useful insights into how long-term, relatively stable local coalitions including various local actors and local governments are established around certain broad goals. According to Stone (2005, $329)$ and Davies (2003, 256-257) urban regimes can be seen as governing arrangements 
producing coherent policy-constellations with an agenda to address a distinct set of problems. This agenda is promoted by "a governing coalition formed around the agenda" whose mission "concerns itself with the economic development of the city although it addresses other issues, depending on who succeeds in grasping the levers of power". ${ }^{24}$

Current analyses developed from this perspective can help us to understand the dynamics of local governance in the context of state re-scaling. According to those studies, it is important to investigate changes in local governance arrangements by locating them "in the achitecture of governmental complexity", and to pay attention to how urban regime construction takes place through active institution building at the local scale with reference to broader (supra-national, national, regional, etc) government structures (cf. Leibowitz 2003, 2618, 2619). Furthermore, the UR framework goes beyond structural-institutional explanations, by emphasising the role of local agency in the context of broader re-scaling processes. Clarence Stone (2005) notes that in urban regime analysis

structures do not form a tight-fitting system and explanation does not take the form of showing how the macrosystem brings about conforming actions. Because structures both constrain and enable, details of how they mix assume importance. .... Urban Regime Analysis thus concerns how local agency fits into the play of larger forces $(2005,323-324)$.

\footnotetext{
24 Various authors identify different temporal and/or spatial categorisations of urban regimes like the 'directive' (1950-1964), 'concessionary' (1965-1974), and 'conserving' (1975 - ) regimes of Fainstein and Fainstein; or the 'pluralist' (1950 - early 1960s, in Northeast and Midwest USA), 'federalist' (mid1960s - late 1970s, in Northeast and Midwest USA), and 'entrepreneurial' (post-World War Two, SouthWest USA) regimes of Elkin; or Stone's 'corporate', 'progressive', and 'caretaker' regimes. As noted, such typologies generally refer to rather stable periods of policy-making in which certain identifiable social groups are favoured (Lauria 1997, 3-4).
} 
The UR framework also indicates that, in general, the local bourgeoisie tends to play a more active role in construction of urban regimes in collaboration with local governments. Logan and Molotch, focusing on the political economy of American cities in the 1980s, contend that "Business people's continuous interaction with public officials (including supporting them through substantial campaign contributions) gives them systemic power" $(1990,62)$, with the result that the collaboration schemes in which the local business community plays a central role tend to be longer lasting arrangements (cf. Davies 2003). Moreover, authors like Clark et al. note that in the present context the adoption of neoliberal agendas by most nation states have led them to promote or favour market dominated urban regimes over other alternatives, thereby strongly skewing local political processes in favour of "corporate regimes" whose “overriding philosophy ... is that the first priority of government should be to promote the expansion and profitability of business firms, thereby elevating industrial and commercial development to the top of the community agenda" (Clark et al. 2001, 51). And, as we shall see, those tendencies have been clearly evident in Gaziantep, especially since 1980 .

Nevertheless, neither acknowledging this systemic power, nor emphasising the influence of neoliberal agendas is sufficient to explain why, how or to what degree business interests have come to the centre of local politics. To answer those questions, first, it is necessary to recall Jessop's reminder that capital in general is not an agent in itself, and neither is the local bourgeoisie, as such. This means that in order to 
understand the dynamics of local corporate regime formation it is necessary to ask who "the bourgeoisie, as a social category" consists of, and how the local bourgeoisie can turn into an "agent" in the re-scaling process. To begin with the former concern, we need to recognise that there are usually different competing priorities favouring particular fractions of the bourgeoisie ${ }^{25}$, and these usually have significant distributive and re-distributive consequences (Clark et al. 2001) as locally established power balances change. ${ }^{26}$ Here, the way in which a certain fraction of the local bourgeoisie is linked to the (new) accumulation strategies will increasingly determine its bargaining power and the degree of its involvement in the formation of a local corporate regime. Of course, for such a fraction to be influential in local governance, its changing economic position has to be translated into a political capacity via effective institutional mobilisation and active lobbying.

Indeed, the UR framework also indicates that urban regime formation is not a smooth process because "Building and enlisting institutional partners proved to be a long term process" (Stone 2005, 312) ${ }^{27}$, and a conflictual one. In this regard, neither the

\footnotetext{
${ }^{25}$ now further fragmented and pitted against each other by a neoliberal competition scheme, and/or fractions of other classes within a locality.

${ }^{26}$ In fact in convential UR analyses, the active involvement of the bourgeoisie in local politics and the discussion of public-private cooperation are almost exclusively focused on land development issues (Lauria 1997; Feldman 1997; Davies 2003), even though in many instances the local bourgeoisie's longterm goals and strategies regarding the economic future of their locality are not only focused on land development (See Clark et al. 2001). Apparently, this earlier conception is built on a narrower view of urban economy, equating 'urban' with 'place' and 'territory', trying to carve out some theoretical room for the ontological autonomy of the urban. The relational-scalar view I adopt in this thesis takes a careful stance against this proposition.
}

${ }^{27}$ What is more, sustaining the arrangements and restriction of the attention to the main agenda, avoiding individual specific issues constitute an important aspect of urban regime efforts: "It not only takes an 
pre-existence of local cooperation (Cox 1997, 100; also see Stone 2004), nor the coherence of local governance systems can be taken for granted. This has to do with the fact that social reality in general, and local political-economic processes in particular, are always in flux, and even more so in a context characterised by national accumulation regime shifts and the associated state re-scaling process. ${ }^{28}$ Within such a context, construction of an urban regime as a relatively stable local governance arrangement can become possible only through effective political mobilisation of those local actors with sizeable stakes in the re-scaling processes. This is also true for the potential role that certain fractions of the local bourgeoisie can play in the formation of urban regimes. These actors have to organise a governing coalition concerned with responding to the changes that increasingly open local political-economies to non-local influences, and that effectively re-constitute local governance as a political process with a multi-scalar focus (Cox 1998; cf. Keil 1998, 640; cf. Genieys 2004). To maintain the coherence of an urban regime constructed with explicit reference to those changes, the leading group(s) has to co-ordinate: a) the presence and actions of other (local and nonlocal) actors in its locality; $b$ ) the continuous process of fragmentation of local interests, especially in cities and regions experiencing waves of economic change; and c) the entry into, or exit from, its local political-economy. Here, it is also important to note institutional infrastructure to develop an agenda in the first place and give it a concrete, workable form, sustained agendas (and purposes within these agendas) need ongoing protection against attention shift" (Stone 2005, 319).

${ }^{28}$ This process is more conflictual and dynamic in the Turkish context where de-centralisation of government and the emergence of the local bourgeoisie as an influential actor in local politics are relatively recent developments. 
that urban regimes formed around a re-scaling agenda can have de-stabilising consequences for the coherence and future of such urban regimes. As various authors observe (McGuirk 2003, 212; Hamel et al. 2006, 4), the re-scaling process of the state, and the associated increasing level of economic openness, render local coalition building and maintenance quite difficult, and can prepare the ground for the dissolution of established urban regimes.

Of course, the local bourgeoisie is not the only player in local politics. Construction of a corporate regime is a delicate task in which the leading fraction(s) have to work to bring together key local actors in support of a viable local agenda. This invariably includes a number of actors and institutions, including the local opinion leaders, local newspapers, elected and appointed local government officials, local civil society organisations, as well as the local branches of political parties, all of whom can contribute to the formation and defence of a locality discourse. In this process certain relatively permanent actors or institutions with links to many local actors can contribute greatly to the formulation and promotion of such a discourse. Long serving mayors (McGuirk 2003) and/or local journalists and media bosses (Logan and Molotch 1990) can play significant roles in formulating such a local vision. Indeed, as we shall see later, in Gaziantep the media played a significant role in the formation of a new governing coalition by helping to achieve a compromise that validated the re-scaling strategy adopted by the most influential local interests.

McCann, who defines the concept of scale as a discursive frame employed by local actors in representation of their interests, argues that 
A major question in urban politics is how each coalition of political actors constructs a relatively consistent discourse, or discursive frame, on the future of the city that resonates with their own political ideology and is persuasive to a wider constituency. These discourses strategically and instrumentally highlight certain aspects of the place and its political, economic, and social context (2003, 162).

At the level of discourse, this establishes the place of the city within the hierarchy of localities, within the regional and national political-economy, as well as its relationship with other political-economic actors at supranational (like the EU), international (other nation states) and global scales. Construction and pursuit of a local accumulation strategy in the context of state re-scaling involves struggling against the hegemonic influence of the localities whose bourgeoisie dominates the agenda of the national accumulation strategy. This amounts to a re-definition of the very meaning 'national' and 'local'. Thus, local actors have to negotiate the scalar nexus they are embedded into as 'boundary spanners', challenging the boundary between the exogenous and the endogenous (cf. Crouch and Farrell 2002), thus negotiating the power relations inscribed into the spatiality of the capitalist state. As they do so, they have to take into account the opportunities and constraints posed by the new politicaleconomic actors and institutions that are being established at various scales simultaneously.

It will be argued that Gaziantep's bourgeoisie responded to state re-scaling by pursuing scalar strategies of representation, which became possible with the organisation of a corporate urban regime, turning Gaziantep into a collective actor. The regime's success has been largely determined by how well these strategies were 
articulated with the transforming global, regional and national political opportunity structures. At the national level these pressures are clearly manifested in Turkey's efforts to become a member of the EU, which has far reaching implications for domestic political and constitutional structures and relationships. In this regard, our investigation of the local politics in Gaziantep has to pay special attention to the priorities of the scalar strategies of representation pursued by (different fractions of) the local bourgeoisie, and how these strategies are constructed with reference to the changing political opportunity structure.

To summarise, especially the recent studies employing an UR perspective make important contributions to our analysis. They indicate that if we are to understand the dynamics of currently rising local agency, we need to investigate: a) why, and when, certain local actors mobilise in political terms to influence the local governance process; b) what sort of an institutional form their mobilisation takes; c) how a governing coalition is established; and d) how non-local developments influence the coalition's composition, its agenda, and the regime promotion strategies. This last question is particularly important to consider in a neoliberal context, which emphasises uncertainity in economic processes and public policy-making, thereby effectively altering the nature of various local actors, their interests and the local power balance. Hence, local actors mobilised to establish an urban regime are compelled to take those broader changes as their frame of reference in an attempt to capture the potential benefits that will flow from broader accumulation regime changes and the state re-scaling process, while avoiding the potential costs to be incurred by such changes on the locality. In this 
regard, urban regimes and the associated scalar political strategies adopted by their governing coalitions effectively serve to contain and shape those changes, ultimately creating an uneven pattern of state re-scaling.

In order to understand how its local bourgeoisie turned Gaziantep into a collective actor in the context of the state re-scaling, we need to investigate how different fractions of Gaziantep's local bourgeoisie mobilised as political agents, and how the local governance structure has changed in response to these developments. According to McCann,

processes of rescaling necessarily entail a disruption and recomposition of the networks of power that tie political actors together within and across scales. The development of a new scalar fix means that new opportunities emerge for political action as others are curtailed. As established political opportunity structures open up, the relative influence of the state in policy formation declines. Under these circumstances, restructuring cannot be assumed to wholly benefit any one interest group. Its outcomes are contingent on the political strategies and opportunities acted upon in certain situations within a larger context. As a result, the study of urban politics needs to investigate these strategies and the use of scale as a framework for political persuasion (2003, 163-164).

In this context, the role of local business associations as representatives of the bourgeoisie assumes importance. In fact, as shown in Chapter 4, local business associations became the institutional core of new local governance arrangements in Gaziantep with the re-scaling of the state during the post-1980 era. Then, how can we conceptualise this increasing significance of local business associations in the context of the state re-scaling? 


\section{Business associations, local politics and the state: Emergence of "scalar strategies of representation"}

The literature on business associations tells us that these institutions serve as sites of interest definition for fractions of bourgeoisie specialised in different areas of production and/or service provision in the economy. Their effectiveness as representatives of those interests is generally thought to depend on the heterogeneity of their membership (in terms of size, geographical location, range of activities, etc); on their formal institutional status as "the interface between the private enterprises and public authorities' or as 'professional organisations'; as well as on the strategies of representation they adopt (Greenwood and Webster 2000; Lehmkul 2000). In general, they often serve as an important institutional contact point between the state and civil society, and therefore constitute a crucial site and/or agent for interest representation in a capitalist society.

In so far as their intermediary role between the public and private spheres is important, this creates a basic tension between the 'logic of influence' and the 'logic of membership' for such institutions (Grant 1983; Streeck 1989; Schmitter and Lanzalaco 1989; Williamson 1989; Lanzalaco 1992; Schaede 2000). Here, the 'logic of influence' refers to the need for business organisations to negotiate with public authorities and other interlocutors in the 'common interests' of their memberships, which may require revision and modification of their original demands and strategies to allow compromises to be reached. Inevitably, this process can create tensions between 
interests as perceived by the membership, and those actually promoted by the association's actions. This is where the 'logic of membership' enters the picture, since it refers to the association's responsiveness to the varying interests and demands of its members.

Drawing upon the insights of earlier studies, Streeck (1989) argues that there is a second source and axis of intra-organisational tension: between the logic of 'goal formation' and the logic of 'effective implementation' - or what Weber calls 'substantive' rationality and 'formal' rationality, respectively. According to Streeck, these organisational logics

operate independently from, and can in fact be seen as running orthogonal to, the logics of intermediation [ie those of 'membership' and 'influence']. The Logic of Goal Formation informs the process by which, both through membership participation and through consultation with, or imposition by, external interlocutors, an intermediary organization selects its manifest and latent objectives. The Logic of Efficient Implementation, on the other hand, relates to the way 'that specified tasks or outcomes', both vis a vis institutional targets and the membership, 'are attained with certainty and economy' (1989, $60)$.

The tensions along those two different axes can be understood as determinants of the interest formation process and can, therefore affect the forms of representation that a fraction of capital would choose to adopt. Indeed, it is through such choices that $a$ class in itself turns into a class for itself (cf. Lanzalaco 1992, 173-174). In this context, Schmitter and Lanzalaco $(1989,214)$ provide us with a heuristic schema of the types of business associations and representation strategies that can emerge out of such processes (Schema 1.1). 
Schema 1.1: The diverse (and sometimes competing) logics of associability

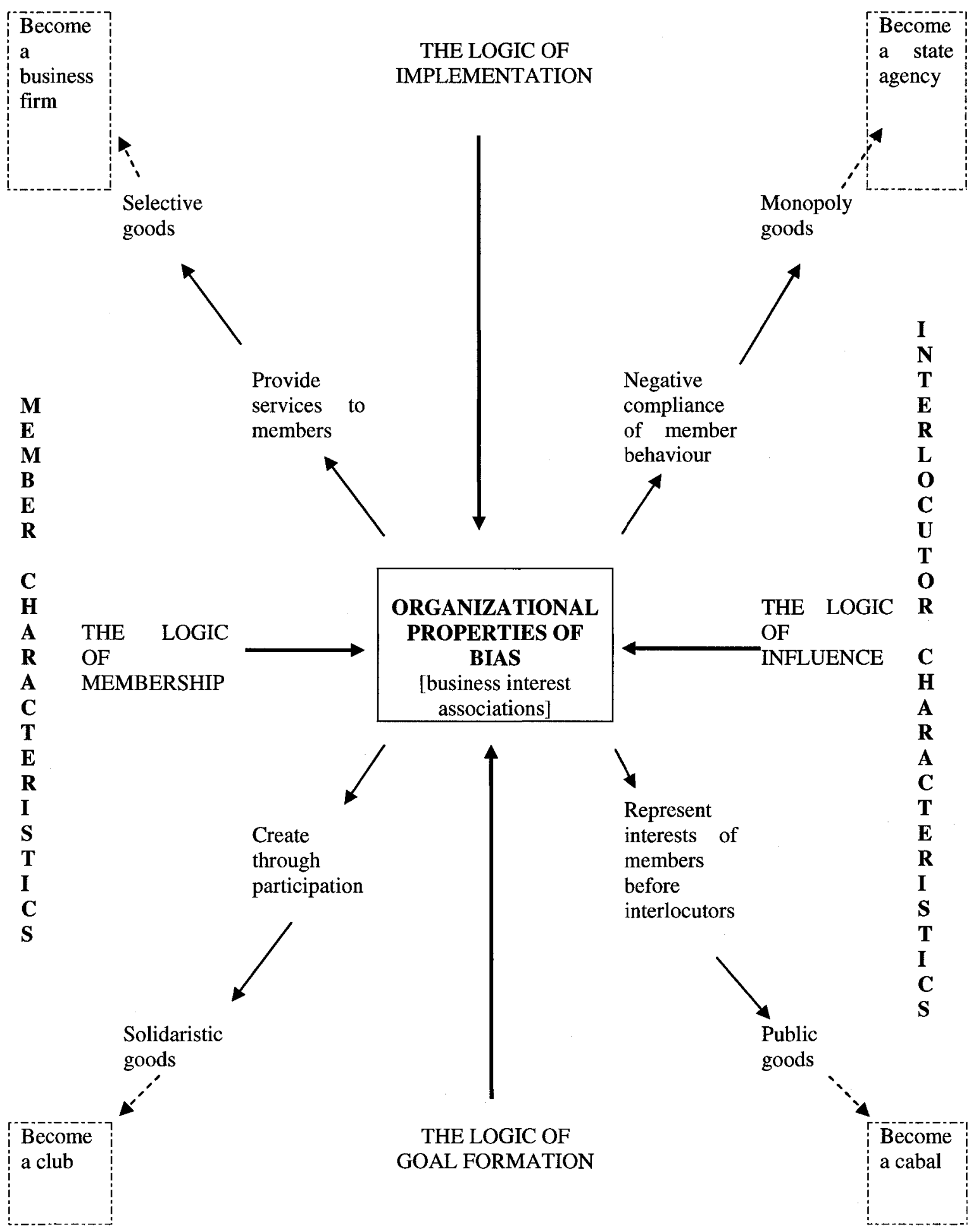


According to this schema, if a business organisation's public status assigns it a considerable number of administrative functions (such as the monopoly for providing certain state services to firms) and if the management of that business organisation becomes preoccupied with the provision of those services and tends to alienate its membership, then, it is effectively transformed into a state agency, or a part of the bureacratic apparatus of the state. As such, it clearly ceases to be a true representative of business interests - even as a simple transmitter of business concerns. At the other extreme, in the upper section of the schema, such associations can become mere service providers effectively acting as private agents, just like any firm producing certain services to customers for an annual fee. In such cases, there is no longer any concern for political mobilisation in defence of a constituency's interests.

The lower part of the schema looks more interesting in terms of the ability of such associations to define and represent various bourgeoisie interests. In cases where the association is in direct contact with - and has direct official access to - important interlocutors (especially the state) it can function as an effective representative of its members' concerns and interests. Yet, as we noted earlier, those interests and concerns as formulated by the leaders of the association may not precisely reflect those of their membership, in part because the leaders have to find a middle ground between the membership's demands and the expectations, limits and demands brought to the table by the state officials and politicians with whom they are negotiating. Here of course, it is important to pin down the locus of the interlocutor inside the state apparatus. One can list a number of levels of the bureaucratic and political pillars of the state: the 
parliament and its committees, the government, the ministry (of industry/trade), the regional offices of various ministries, the local government, etc. It can be suggested that the business association has to deal with all of them simultaneously, meeting the priorities of each or colloborating with some while conflicting with others, as certain demands brought to the table by these interlocutors may also represent the interests of other groups they are supposed to, or elected to, serve.

Ultimately, the schema suggests the possibility that in extreme cases the leaders of such business associations can co-opt the representatives of the state or other interlocutors, especially in situations where a powerful actor, like a holding company or business group, dominates a local economy. In such cases, business associations can be used to serve the interests of a few strong firms within them. Yet, as Laothomatas (1992) notes, such domination can be challenged if the other constituent firms grow and become more actively involved in the organisation, thus lessening the dominance of the founder or influential names, groups, etc. Such challenges usually come following the changes threatening the status quo, such as broader accumulation regime changes. It may be argued that when such moments are associated with increased political consciousness among the association's wider constituency these newly mobilised elements could use their voting power to facilitate the transformation of their political representation, thereby moving from being a class (fraction) in itself to becoming a class (fraction) for itself. In terms of the schema, the situation would shift to a middle point in the continuum between the logic of membership and the logic of influence as increased intra-organisational democracy challenged both the hierarchical relations 
within the associations as well as the clientelistic relations between the association and their interlocutors (mainly state actors) (Laothomatas 1992).

If that kind of a challenge is not successful in bringing about such changes, then, depending on the institutional flexibility of the umbrella business association, new specialised sectoral or territorial sub-units that break away from the original representative organisation can achieve an increased capacity to represent their sectors or locality as independent actors. Such an organisational split will invitably force the splinter group to seek new interlocutors as there will not be much tangible benefit, i.e, 'solidaristic goods', to be directly gained by its interaction with older interlocutors. New interlocutors have to be those whose requirements and expectations would approximate the interests of this new business association's membership. As we shall in Chapters 4, 5 and 6, a previously un-influential level of the government, for example local governments, can gain significance as an interlocutor following certain politicoadministrative reforms. Or, in other cases, the focus could shift from the bureaucracy to political parties, or vice versa, or even to new international/supra-national actors, like the EU, etc or certain international corporations.

In effect, one is dealing with a double-edged re-scaling process: (a) the rescaling of the main business associations in response to intra-organisational restructuring processes reflecting the conflicts and compromises of intra-business struggles triggered by the need to face new challenges; and (b) the re-scaling of the field of action for those business associations as the locus and nature of their interlocutors change. Both processes are best understood as part of a dialectical process of 
fragmentation of, and co-ordination across, different fractions of the bourgeoisie as they adapt their strategies of representation to the shift from a Fordist to a flexible, neoliberal accumulation regime. As long as we are concerned with the first dimension to this rescaling process, the forces of economic globalisation encourage rapid change, fragmentation and diversification among the members of each business association. This forces the leaders of such organisations to seek out new intra-organisational compromises and means of coordination among the membership in a move to avoid potential splits that would damage the credibility and the financial basis of their associations (Schaede 2000, 67; cf. Keil 1998, 640). This dialectical tension inside the business associations increasingly turns the class formation process into a hotly contested one. Although it is difficult to label Turkey's recent economic transformation as a passage from a well established Keynesian Fordist economic regime to postFordism, its pre-1980 Import Substituting Industrialisation strategy clearly had some important Keynesian features, which ultimately created the basis for a flourishing and diversified industrial bourgeoisie in Turkey, and especially in Gaziantep, during the neoliberal post-1980 period.

As for the re-scaling of the field of action for business organisations, this has to be seen as an integral part of the political and institutional re-scaling of the state that is changing the nature and locus of the main interlocutors for business associations and business interests. In response, business associations are forced to expand the range of their formal partners, and to lessen the pressure of the logic of influence over the logic of membership in order to protect the organisation's cohesion and integrity. At the same 
time, this expanded range of interlocutors tends to increase the bargaining power of these organisations vis a vis the state, by increasing their political and economic room for maneuver. Ultimately, this double-edged re-scaling process is crucial for understanding the changing relationship between increasingly 'active' localities and the capitalist state. And, as this thesis shows the outcomes of this change are substantially shaped by the scalar strategies of representation that are pursued by local business associations.

The questions that remain are how does this double-edged re-scaling process contribute to increased local agency and how does it shape the scalar strategies of representation adopted by local business associations? To begin this discussion, it is necessary to note that territoriality constitutes one of the most important dimensions of differentiation inside the bourgeoisie (Coleman and Jacek 1989). Local and urban civil society existed long before the establishment of the nation state, and as members of local civil society, business associations have long played a significant role in the social life and in the political-economy of cities. Thus, the seeds and institutions of local bourgeois rule go back a long way, and local business associations can be seen as the prototypes of later national business organisations (cf. King 1983). Of course it is true that over time their regulatory and coordination functions have been re-scaled with most responsibilities transferred to their national umbrella organisations, when they were not transferred to the state itself. In this context, these national umbrella organisations assumed vital importance as key channels of communication with the apex of the state and with representatives of the working class, providing significant scope for planning, 
coordination, and compromise between nationally organised political-economic actors. Within this context, local business associations were increasingly assigned the role of implementing and rationalising nationally determined policies.

Within the context of the rescaling of the dissolution of the Keynesian national state, there is a simultaneous organisational and political rescaling of the representative institutions of the bourgeoisie, and of their strategies of representation. Moreover, in the Turkish case, the roots of this development can be traced back to the increased conflicts between different fractions of capital within the business community's national umbrella organisations. As noted earlier, the logic of influence becomes more important if business associations work closely with the state. In a context characterised by such close collaboration between the political and bureaucratic apparatus of the state and various fractions of the bourgeoisie, these increasing intra-class struggles of the bourgeoisie were directly imported into the political sphere, and became more explosive as a result. The dissolution of Turkey's Keynesian welfare state, and of spatial Keynesianism, should therefore be understood in large part as a result of intra-class tensions within the Turkish bourgeoisie that reached its height in the 1970s. These intrabourgeoisie struggles contributed to the country's political instability, which eventually invited the 1980 Coup and paved the way for the introduction of neoliberal policies.

The dissolution of this close collaboration between business and the state, as a result of the increasing contradiction between the 'logic of membership' and the 'logic of influence', can eventually push the increasingly resentful and excluded fractions of the bourgeoisie, and "their" representative business associations, to look for new 
institutions or actors through whom they can further their particular interests while building new links to a re-scaled state. Within an organisational context characterised by the weakening of national representative institutions, some increase in the autonomy of local and regional actors including business associations would seem all but inevitable, allowing them to emphasise their 'locality', especially given that territoriality is often a strategic dimension of organisation, especially for the (challenger) smaller business communities (Grote 1992, 122). In this sense, such an organisational re-scaling process can increase the control and influence of local business associations over their members and over the fate of their own local economies. This is so because of the fact that the re-scaling of the state increases the stakes to be (re)distributed to or from the local scale, thus strengthening the hand of local business associations, increasing their significance in local politics and in the eyes of the local constituency, which was the case in Gaziantep.

To fully capture the impact of the re-scaling of business associations on local politics, it is necessary to consider how the changing logic of membership is linked to the increasing significance of those local business associations in local politics. Here, Harvey's emphasis on local accumulation strategies, combined with the insights of the scale literature, can help to elaborate on this link and to explain the local bourgeoisie's adoption of certain scalar strategies of representation in response to these challenges. Although causation runs both ways to a degree, there is no doubt that the local balance of power between classes and class fractions is always vulnerable to major power shifts in the accumulation strategy at non-local scales. In our case, the Keynesian economic 
strategy pursued by Turkey during the $1960-1980$ period initiated a transformation of the bourgeoisie, while heating up an intense rivalry between its industrial and commercial fractions, as well as between small scale capital and big capital. These tensions surfaced with the challenge of the relatively small scale industrial capital from Anatolian cities. As we will see in Chapters 2, 3 and 4, this introduced fractures inside the local bourgeoisies. Changing intra/inter-class balances ${ }^{29}$ re-determined the priorities of local accumulation strategies ${ }^{30}$, as well as the way non-local political-economic actors were articulated with the local accumulation process. Given the fact that Gaziantep's economic articulation with the national and the global economy is a recent phenomenon, we can expect to see a lower level of engagement on the part of the nonlocal political actors in local politics. In fact, the non-local actors who are currently developing an interest in Gaziantep's political-economy are those invited by Gaziantep's business associations via establishment of new alliances and partnership regimes.

Localities necessarily respond to broader developments in ways that seek to maximise their benefits, while minimising risks and costs and, of course, each interest group has a different way of calculating those risks, benefits and costs. In times of rapid change when the non-local regimes of accumulation are in flux, and when most existing institutional, political and economic linkages are suddenly called into question, there is

29 and the "internal hierarchy of groups and their monopoly of representation" (cf. Anderson 1992, 28).

${ }^{30}$ This, to be sure, has been a slow process. In the case of Gaziantep, for example, the industrial capital in Gaziantep emerged as a political power especially from the mid-1990s onwards, although the political mobilisation and transformation of the local bourgeoisie started in the late 1970s. 
an increased urgency for local actors to find new representational strategies capable of protecting them to a degree against potentially devastating losses, while at the same time improving their political bargaining power and chances of capturing some of the gains that are invariably also associated with such moments of transformation. In other words, the scalar strategies of representation pursued by these local actors are informed by the concerns of compensation and/or domination, depending on their relative position vis a vis the accumulation regime changes. This is the context within which to understand the ability of some local bourgeoisies to develop successful new strategies of representation in response to the threats and opportunities associated with the rescaling of the Turkish national state. Given that this transformation has tended to enhance the power of market actors, it is not surprising that the resulting opportunity structure (Miller 1994) has allowed certain fractions of the bourgeoisie to enhance their position of power within the local political sphere, and then to use that power to develop new linkages with national and supra-national actors through which they have gained access to additional resources (cf. Weiss 1988, 204), thereby further entrenching their power at the local level.

\section{Conclusion}

This discussion of theory suggests that the increasing significance of many cities and regions as loci of political-economic decision-making is best understood as a part and expression of the spatial re-scaling of the capitalist state. The concrete manifestations of 
these tendencies are the product of local agency, and cannot be understood merely as automatic responses to broader structural changes labelled as 'globalisation' or the 'hollowing-out of the state'. This first chapter argued that this agency is produced through the creation of local governance arrangements around a coherent policy agenda with (re)distributive consequences, called 'urban regimes'.

We noted that both the historical role of local business communities in their local political-economies, and the recent shift to a post-Keynesian accumulation regime facilitated by neoliberal policies, increasingly favour pro-business urban regimes, namely "local corporate regimes". Nevertheless, if they are to translate their enhanced economic power into a local policy-making capacity and/or to produce local governing arrangements that can be functional to protect their established particular interests, (fractions of) local bourgeoisies have to organise themselves as collective political actors. Here, local business associations play a central role. Local corporate regimes, thus understood, are local governing arrangements based on the leadership of local business associations, in cooperation with a number of key local actors, seeking to promote specific local accumulation strategies in the context of broader accumulation regime changes and the associated scale re-scaling process.

To be able to implement a local accumulation strategy it is necessary for local corporate regimes to develop strategies to intervene in, and to contain, the state rescaling process to some degree. Our theoretical discussions indicated that this agenda is pursued through "scalar strategies of representation" which can be understood as discourses, strategies and efforts, a) to develop interscalar arrangements favourable to 
the representers' interests; b) to institutionalize their access and power position; and c) to benefit from the broader accumulation regime changes while minimising the potential costs that may flow from such changes. In the chapter I identified two types of scalar strategies of representation: territorial strategies and institutional strategies. The former aim at expanding the locality's sphere of influence by establishing partnerships with new interlocutors that allow one to open up new markets and areas of accumulation, and to escape domestic (national) and local threats to local accumulation, while also striving to enhance the credibility of local actors in the eyes of the national state and other national actors. Institutional strategies aim at actively re-shaping and controlling the power relations already institutionalised at the national scale, while targeting the benefits provided by the state through these arrangements. The re-scaling of the internal form of organisation of the national state (and other national organisations constituting part of the integral state, such as the umbrella organisations of the local business associations) provides an altered opportunity structure, encouraging and facilitating institutional re-scaling strategies.

The chapter also indicated that re-scaling strategies pursued by corporate local regimes have a potential to destabilise the basis upon which they are established. Especially, the increasing openness of the economy to non-local influences and the stretching of the local political arena across non-local scales leads to fragmentation of the interests at the local level and increases the number of political-economic actors who develop an active interest in that locality, thus rendering the maintenance of a regime's coherence more difficult than ever. 


\section{CHAPTER - II}

\section{"The historical context"}

Our theoretical discussion indicates that the recent rise of local agency and entrepreneurialism has to be understood as a part of the current capitalist state re-scaling process that has been informed by a neoliberal agenda. Our preceding analysis also emphasised the need to locate our analysis in its spatio-historical context. This includes the period marked by the reign of the nation state as the prevalent politico-institutional form of the capitalist state. Here, we need to pay close attention to the changing relations between the state and local actors, and especially the local bourgeoisie, to avoid producing simplistic accounts of 'local particularism' and seeing the rise of cities and regions as a brand-new development, the product of neoliberal 'market liberation'.

Our discussion builds on the view that the state's active engagement in laying and maintaining the foundations of market economy ${ }^{31}$ has been critical for the continuation and success of capitalist accumulation. Even though neoliberal policies have increasingly curbed direct and active state involvement in these areas, as this chapter will show, this has not weakened the political interest of the bourgeoisie in the state's potential contribution to the conditions of its success. On the contrary, the

\footnotetext{
31 through provision of the physical and institutional infrastructure, investment in skills and technological capabilities, and provision of political stability, economic regulation etc.
} 
increasing scarcity of resources to be directly provided by the state, as well as the need for a strong ally in an uncertain economic environment, have highligted the state's significance as a site of representation for the bourgeoisie. Institutional re-scaling of the capitalist state, along with the re-scaled forms of distribution and re-distribution, pushed different fractions of the bourgeoisie - divided along sectoral and/or territorial lines - to respond to these changes, and in particular, triggered an active search for mechanisms of compensation for the active support that used to be provided by the Keynesian national state.

The rise of the local bourgeois activism has to be understood not as an evidence of the withering away of the national state, but as a part of a struggle to redefine the meaning of "national" in the re-scaling process of the "capitalist" state. This involves re-territorialisation of the scope of state interventions and support. Employing the analytical insights of the scale literature I have argued that the very notions of "national" and "local" should be understood as mutually constituting instances of a territorially-delimited political-economic entity whose relationship is always open to contention. Demarcation of the boundary between the "national" and the "local" bears a clear reference to a hierarchy of localities, which reflects a spatial crystalisation of intraand inter-class power balances, as suggested by the uneven development literature. Hence, the challenge to the scope of action of the state, i.e, redefinition of territoriality of the "national", and the response to its re-scaling, takes the form of local entrepreneurialism. This is also true for our case where the rise of Gaziantep's entrepreneurialism reflects a redefinition of the boundaries between the national and the 
local in the process of re-scaling of the Turkish state. It is important to note that this recent transformation of the Turkish capitalist state that facilitated the emergence of Gaziantep's local entrepreneurialism has been associated with a change in the composition of the bourgeoisie and intra-bourgeoisie power balances, as well as with a change of logic in the state-bourgeoisie relations, whose roots can be traced back to the Keynesian economic policies of the pre-1980 period in our case.

This chapter will develop the above arguments in three sections. The first section concentrates on the period from 1923, when the republic was established, to 1960, when the Import Substituting Industrialisation strategy was put into effect. The section shows that seeds of the current divide between the İstanbul-based bourgeoisie and the Anatolian "local" bourgeoisies can be found in the way in which the broader relations between the state and the bourgeoisie were structed, in line with the long-term economic strategy of the new republic. Section two develops the argument that current local bourgeoisie activism and the associated struggles around the definition of "national" bourgeoisie and "national interest" are indeed products of an accumulation strategy shift, i.e, the adoption of the Keynesian Import Substituting Industrialisation strategy, and the associated changes in the form of state intervention. The last section focuses on the post-1980 period, which witnessed another accumulation strategy shift, following, yet, another Coup D'état: transition to a neoliberal, open, and export-oriented economic regime. It was during this period that Gaziantep's local bourgeoisie activism took the form of local entrepreneurialism as the interests of Gaziantep's local 
bourgeoisie were re-defined and re-scaled in response to the national accumulation strategy shift.

\section{In search of a national bourgeoisie (1923-1960)}

The creation of a national bourgeoisie was considered an important means of establishing the Turkish Republic as an independent nation state. ${ }^{32}$ As Köker (1990) notes, the war of independence had been led by a coalition of (modernist) military and civilian bureaucrats, notables, traders and big land-lords, and their dominance was institutionalised in the Republican People's Party (CHP) as the single ruler of the republic. Small farmers, artisans, workers and the self-employed were marginalised (Tekeli and İlkin 1982, 326). This main economic policy of the new republic reflected the concerns of this coalition (Ramazanoğlu 1985a, 52; Mardin 1980, 35; Lewis 2002, 459-460; İnsel 1984, 138). ${ }^{33}$ While the representatives of the new Turkish state were negotiating the terms of independence with the Allies in Lausanne, the first economic

\footnotetext{
${ }^{32}$ The fall of the Ottoman Empire was marked by the Allied invasion of Anatolia (1918-1922), the last fortress of the empire mainly populated by Turkish Muslim population. The invasion sparked sporadic and autonomous local resistance movements, eventually unified by Mustafa Kemal (Atatürk) and his cadre under the umbrella of the national resistance organisation, "Kuvva-i Milliye". Local elites, including those of Gaziantep, played an important part in the organisation of those movements. The War of Independence lasted three years leading to the withdrawal of the Allies in 1922, followed by the declaration of the independence of the Republic of Turkey in 1923.

${ }^{33}$ The intertwined nature of the ideals of 'political nationalism' and 'economic nationalism' found their expression in the early figures of the Turkish bourgeoisie: They were all members of the "Union and Progress Party" (Ittihat ve Terakki Firkası - ITF), founded by the Young Turks. Bugra maintains that the role played by the members of the ITF went beyond that of a state authority encouraging national industry and trade. They became entrepreneurs, thus initiating the development of a Muslim bourgeoisie (1994, 73-74, 83).
} 
congress of Turkey was convened in İzmir in $1923^{34}$, where the creation of a national bourgeoisie was formulated as a state strategy (Mardin 1980, 38; İnsel 1984, 136-143; Ramazanoğlu 1985a, 49-53; Keyder 1989, Chapter 4; Başkaya 1991; Buğra 1994, 6483; Ahmad 1995, 137; Yalman 2002, 26).

There were two factors that rendered this task difficult. First, the Ottoman economy had been under the control of the non-Muslim minorities, and Turkish elements of the Ottoman bourgeoisie inhereted by the new republic were few in numbers. ${ }^{35}$ Second, from the early 1910 s to the mid-1920s the ethnic structure of Anatolia radically changed with the vacating of Anatolia by non-Muslim minorities ${ }^{36}$ (Mardin 1980, 38). This meant substantial loss of social capital and technical knowledge, along with financial sources that would be needed to initiate an economic renaissance. These factors further emphasised the role of the state in establishing a functioning capitalist economy and the creation of a national bourgeoisie, which could

\footnotetext{
${ }^{34}$ For a detailed, first hand account of the story of the congress, including the concerns raised, discussions held and decisions taken at the congress, see Karabekir (2001). This book, edited by O. Hulagu and O.H. Özalp, brings together the congress notes, and memoirs and other documents about the congress written by the president of the congress, Kazım Karabekir, one of the leading members of the Kemalist cadre and a prominent general of the army.

35 They were especially influential in the cities like Aleppo (Masters 1999), Ízmir (Goffman 1999), and İstanbul, where they had established strong economic relations with the colonial trading powers and the capitalist world economy (Çavdar 2000). Bugra, referring to the ownership records (of the late Ottoman era) notes that only $19,6 \%$ of the privately owned factories were controlled by Muslims (including those other than Turks), while the non-Muslim minorities enjoyed the ownership of the 80.4\% (Bugra 1994, 68). Nevertheless, Lewis observes that, despite their economic status and political immunity, the nonMuslim minority "had never been able to rise to the social and political role played by the new middle classes elsewhere. However great their economic power, it was to a large extent neutralized by the Ottoman system of communal organization, which effectively prevented them from exercising much influence on Turkish society and Turkish state" $(2002,473)$.

${ }^{36}$ The Armenian tragedy of 1915 created by the nationalist policies of the ITF's (İttihat ve Terakki Firkas1) Young Turk governments, the War of Independence, and subsequent population exchange between Greece and Turkey in 1925 contributed to this development.
} 
contribute to initiating and spreading (capitalist) economic development across a wartorn country.

In this early economic vision of the republic, the state's role was originally limited to laying the foundations of a capitalist economy through large scale infrastructure investments and institutional reforms. The national pact reached at the end of the İzmir congress in 1923 envisaged a rather liberal economic system based on private property and enterprise. In addition, according to the decisions of the İzmir Congress, foreign investment was not rejected, although it was not to be given preferential treatment (Zürcher 1993, 203; also see the quote from Mustafa Kemal [Atatürk] in Köker 1990, 182). Interventionism and protectionism characteristic of a nationalist economic strategy emerged slowly. ${ }^{37}$ Nationalist measures such as the restriction of sea trade to Turkish companies and the abolition of foreign chambers of commerce in Turkey came later, in 1927 , in a response to active lobbying of Turkish entrepreneurs who were willing to assume the role previously played by the nonMuslim minorities (Keyder 1980). ${ }^{38}$ Not surprisingly, this development coincided with the establishment of the Higher Economy Council as a venue of close cooperation

\footnotetext{
${ }^{37}$ In fact, certain articles of the Lausanne treaty signed between the new republic and the allies in 1923 , whereby the independence of Turkey had been recognised, had specifically obliged the republican governments not to implement protectionist economic policies before 1929.

${ }^{38}$ The gap created by the widthdrawal of minorities from the economy, however, was initially filled in by foreign firms. The Turkish bourgeoisie moved in later, to assume the leadership in national economy, and effectively lobbied for this purpose through the new Turkish chambers of commerce which had been granted semi-official status in 1925 (Keyder 1980).
} 
between the state and business ${ }^{39}$, which allowed elements of the early Turkish bourgeoisie to be more vocal in the formulation and implementation of economic policies. ${ }^{40}$ The world economic crisis of 1929 also worked well for this emerging national bourgeoisie in that the range and degree of state protectionism increased to their favour.

Yet, the scope of this second phase of state interventionism was still framed so that private entrepreneurship would not be harmed, and state investments would complement private investments. The statist economic policy of the post-1929 period was formulated in two reports: a) The National Union of Industry's (Milli Sanayi Birliği) report to the General Secretariat of the Higher Economy Council (Ali İktisat Meclisi Umumi Katipliği) dated 27.12.1932 (Tekeli and İlkin 1982, E301-E321); and b) The Higher Economy Council's 1933 report entitled "How industry can be established and develop(ed) in Turkey" (Türkiye'de Sanayi Nasıl Teessüs ve İnkişaf Edebilir) (Tekeli and İlkin 1982, E323-E342). The Union's report argued that, for the entrepreneurs, industrial investment was riskier than trade. Therefore, the state should

\footnotetext{
39 Another important step taken in that direction was the law of "Encouragement of Industry" (Law \#1055) in 1927, which had been adopted after modifying an earlier law passed by the Young Turk government in 1913. The law offered significant decreases in transportation costs, free land provision for factory building and lower tariffs for the imports made to establish/sustain industrial enterprises. According to a report prepared by the National Union of Industry in 1932, between 1913 (when the first version of the law was introduced) and 1923, only 189 factories were established. This number reached a total of 400 by 1927 when the republican law of encouragement was introduced. In the report, it is mentioned that in a 5 year period (1927-1932) this total passed 2,000 (Tekeli and Ilkin 1982, E314). This indicates that the law had a considerable impact, despite all its deficiencies.
}

40 The council was established following the examples of European countries like France and Italy. Half of its members were members (ministers) of the government, and the other half were drawn from the chambers of commerce, industry and professional organizations. Workers were not represented (İnsel 1984, 150). 
take an active role in the establishment and promotion of especially heavy industries (Tekeli and İlkin 1982, E314). In the Union report, two types of large-scale investment were singled out: 1) industries that derived their raw materials from the agricultural sector, available within the boundaries of the country (in the sectors of food, furprocessing, wood-processing, etc.); and 2) industries that required imported inputs or needed large scale investment, such as mining and metal processing (iron, chemical, electricity). In the former the initiative should be left to the private sector, while the latter should be the responsibility of the state (E308). The report prepared by the Higher Economy Council (1933) echoed the policy suggestions of the Union's report, but protection was not to be applied universally. It had to be sector-specific. In addition, big enterprises were favoured against small enterprises (E330 - E331, E338).

This industrialisation strategy delayed the birth of local bourgeoisies in Anatolia, who would later join the league of powerful entrepreneurs making up the national bourgeoisie. It was especially the İstanbul- and İzmir-based capital (cf. Ramazanoğlu 1985a, 56) who acted as the representatives of the "national" bourgeoisie (cf. Okçuoğlu $1999,287)^{41}$ in the council. The role designated to this mainly İstanbul-based national bourgeoisie in the industrialisation strategy was to invest in the sectors that would use the natural and agricultural resources in Anatolia (Okçuoğlu 1996, 694). Yet, these capitalists were reluctant to invest in the Anatolian cities (Avcığlu 1979). It was only the state's large scale industrial investments, made with a territorially sensitive

${ }^{41}$ Some of the planned sugar factories whose construction was prevented via active lobbying of the importers (Avcioğlu 1979, 384-387) constitute a good example in this sense. 
approach, which reached Anatolian cities (Günçe 1981, 121; Ahmad 1995, 140). Although these investments contributed to the economic vitality of various Anatolian cities, their spin-off effects were initially restricted to creation of employment, as their production did not rely on local inputs. In the case of Gaziantep, there was virtually no state investment, with the exception of two small factories whose impact on the local economy was almost too small to be felt. ${ }^{42}$

Map 2.1: The geographical regions in Turkey

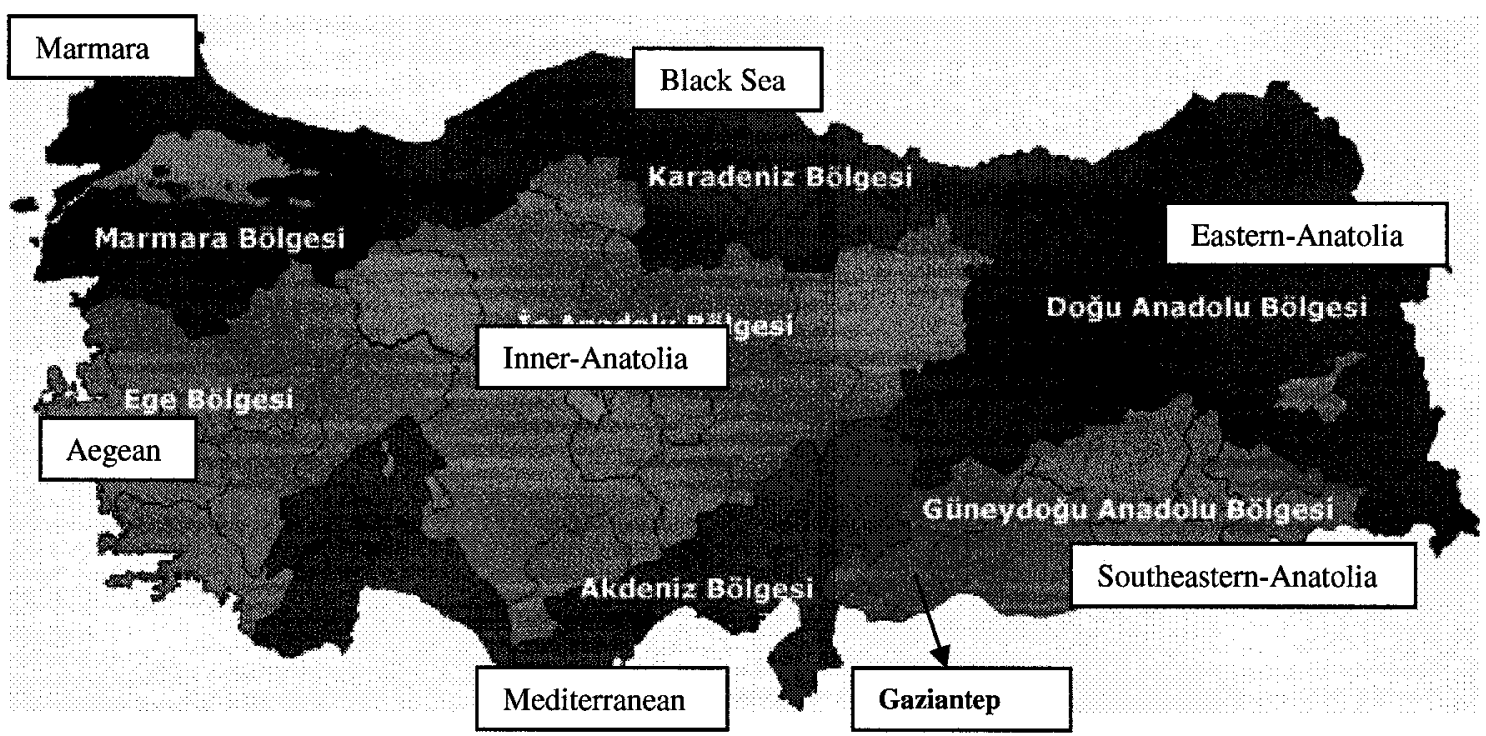

Source: http://www.dpt.gov.tr/bgyu/biid/cog bolge.html

In fact, certain Anatolian cities, including Gaziantep, could have experienced industrialisation much earlier, given the presence of smaller scale labour-intensive industrial enterprises (Okçuoğlu 1999; Table 2.1 and Map 2.1). For example, as of

\footnotetext{
${ }^{42}$ A point proudly raised by Gaziantep's entrepreneurs today.
} 
1927, Gaziantep ranked $7^{\text {th }}$ in the country in terms of the number of enterprises, and these enterprises had a relatively large employment potential. Nevertheless, as noted, the post-1929 industrialisation strategy favoured large-scale enterprises, leaving smaller ones to face their own fate (cf. Kepenek and Yentürk 1997, 38-39). International economic turbulances proved disastrous for these unprotected small enterprises, which further contributed to the delay of industrialisation across Anatolia.

Table 2.1: Distribution of industrial enterprises in selected provinces (top $12+$ Adana, Ankara, Diyarbakır and Kayseri) according to the industrial census of 1927 (in a descending order).

\begin{tabular}{|l|l|l|l|l|l|}
\hline Province & $\begin{array}{l}\text { Geographical } \\
\text { Region } \\
\text { (see Map 2.1) }\end{array}$ & $\begin{array}{l}\text { Number of } \\
\text { enterprises }\end{array}$ & $\begin{array}{l}\text { As \% } \\
\text { of } \\
\text { country } \\
\text { total }\end{array}$ & $\begin{array}{l}\text { Total } \\
\text { number of } \\
\text { workers }\end{array}$ & $\begin{array}{l}\text { Size of the } \\
\text { workforce as } \\
\text { \% of country } \\
\text { total }\end{array}$ \\
\hline İstanbul & Marmara & $\mathbf{8 , 6 3 4}$ & $\mathbf{1 3 . 2}$ & $\mathbf{4 2 , 5 8 2}$ & $\mathbf{1 6 . 6}$ \\
\hline Izmir & Aegean & $\mathbf{3 , 5 2 2}$ & $\mathbf{5 . 4}$ & $\mathbf{2 7 , 8 2 1}$ & $\mathbf{1 0 . 8}$ \\
\hline Bursa & Marmara & 3,209 & 4.9 & 9,886 & 3.8 \\
\hline Balıksir & Marmara/Aegean & 2,597 & 4.0 & 11,102 & 4.2 \\
\hline Konya & Inner-Anatolia & 2,245 & 3.4 & 5,327 & 2.0 \\
\hline Manisa & Aegean & 2,122 & 3.2 & 5,338 & 2.0 \\
\hline Gaziantep & Southeastern-A. & $\mathbf{2 , 0 1 6}$ & $\mathbf{3 . 0}$ & $\mathbf{7 , 8 8 7}$ & $\mathbf{3 . 0}$ \\
\hline Kastamonu & Blacksea & 1,882 & 2.9 & 4,867 & 1.9 \\
\hline Kütahya & Aegean & 1,812 & 2.8 & 5,451 & 2.0 \\
\hline Denizli & Aegean & 1,581 & 2.4 & 3,801 & 1.5 \\
\hline Zonguldak & Blacksea & 1,341 & 2.0 & 11,325 & 4.4 \\
\hline Aydin & Aegean & 1,285 & 2.0 & 10,259 & 4.0 \\
\hline Ankara & Inner-Anatolia & 1,276 & 1.9 & 4,243 & 1.6 \\
\hline Kayseri & Inner-Anatolia & 1,096 & 1.7 & 6,747 & 2.6 \\
\hline Adana* & Mediterranean & 970 & 1.48 & 6,119 & 2.38 \\
\hline $\begin{array}{l}\text { Diyarbakı** } \\
\text { 43 }\end{array}$ & Southeastern-A. & $\mathbf{7 7 3}$ & 1.18 & 3,276 & 1.28 \\
\hline Country & & 65,245 & 100 & 256,885 & 100 \\
\hline Total & & & & & \\
\hline
\end{tabular}

Source: Adapted from Okçuoğlu (1999, 264-266).

${ }^{43}$ Percentage values for those provinces $(*)$ were calculated and added to the table by the author. 
One could argue that capture of the international-domestic trade connections previously controlled by minorities contributed to the capital accumulation of Turkish entrepreneurs, and thus to the formation of local bourgeoisies across Anatolia, who were mainly occupied with commerce. Yet, this replacement did not instigate a widespread capital accumulation process that could ultimately contribute to the emergence of stronger local bourgeoisies in Anatolia. There were two reasons: First, Anatolian entrepreneurs did not have a say in the determination of the national economic policy, and thus the terms and sectors of protection, which would ultimately influence the prospects of a local accumulation based on trade. ${ }^{44}$ Second, the politicoadministrative centralisation of the state ${ }^{45}$ under the single party rule of the Republican People's Party (CHP) had effectively restricted the opportunity of a state-supported capital accumulation to a narrower set of local actors. Being a local notable was not sufficient to secure the support needed to become a local capitalist. ${ }^{46}$ To establish close ties with the state and the CHP was a strategic necessity for those local actors (cf. Güneş-Ayata 1994) who sought to become entrepreneurs, and for the existing local entrepreneurs who wanted to broaden the horizons of their business. ${ }^{47}$ Nevertheless, the

\footnotetext{
${ }^{44}$ Especially given that industrialisation based on small local enterprises was not an option.

${ }^{45}$ As Karpat states, "[t]he creation of a territorial Turkish nation-state was the chief task entrusted to CHP" (1991, 43). To achieve this goal, a centralised administrative system was established emulating the French provincial system. In addition, after 1935 the party representatives became the state officials with the merger of the party and the state into one (cf. Karpat 1959).

${ }^{46}$ Mardin argues that rival groups of local notables tended to associate themselves with the political centre to gain some advantage over the other group(s) $(1990,66)$.
} 
early economic policies of the republic and the reluctance of the İstanbul-based capital to go to Anatolia kept İstanbul's bourgeoisie at arms length from Anatolia, leaving an opportunity for local entrepreneurs to develop as a local bourgeoisie. As we shall see later, the approach of the bureaucratic-political apex of the state to the question of business representation also contributed to this lack of interest and communication between the İstanbul-based capital and the local entrepreneurs in Anatolia.

In sum, despite the fact that the state had assumed full responsibility and leadership in reviving the country's economy, and had pursued a geographically balanced industrial investment strategy, the imbalanced geographical representation of the emerging national bourgeoisie in economic policy-making - based on the existing hierarchy of localities - influenced the territoriality of capitalist accumulation in Turkey, by maintaining and deepening the distinction between the İstanbul-based capital and Anatolian capital. This sowed the seeds of the later struggles regarding the definition of "national interests", which surfaced in the 1970s. Why and how did this tension blossom in the 1970 s, but not earlier? There were a number of reasons: First, local bourgeoisies in Anatolia were neither strong economically nor politically. Under the heavy surveillance of the CHP, there was not much room to develop a separate political identity as a local bourgeoisie capable of dominating the local political scene. Second,

\footnotetext{
${ }^{47}$ The building of Ankara as the capital of a new republic was a good example of this. The creation of a new national capital was one of the main projects of the government. The urbanisation of Ankara meant the undertaking of major construction projects. This created an important source of rent and speculation (Şengül 2001), leading also to the creation of an entrepreneurial group close to the state. For instance, between 1933 and 1939, 311 million Turkish Liras (TL) were spent on public work projects (including the construction of the capital city, Ankara), while the total of industrial investments, combining the public and private enterprises, was not more than 145 million TL (Insel 1984, 157).
} 
given the obstacles to the local industrialisation, local business interests relied mainly on commerce as the source of accumulation. Thus, sectoral differentiation between the İstanbul-based capital - also dominated by commercial interests - and Anatolian capital, which could have instigated sector-based clashes, did not emerge. During the period following WW2, it became clear that both parties' interest lay in promoting an economic strategy prioritising the commercial sector. This was true especially during the 1950s when both the İstanbul-based bourgeoisie and local bourgeoisies in Anatolia were unified under an umbrella organisation and threw their support behind an open economic policy promoted by the Democratic Party, which ended the single party rule of the CHP in 1950.

Despite the adoption of a capitalist economic model, and the significance attached to the concerns of the early elements of the Turkish bourgeosie in formulation of economic policies, until the end of WW2, members of this new national bourgeoisie were not completely independent of the political patronage of the state officials and bureaucrats who had founded the republic. This was true for the entrepeneurs from İstanbul and İzmir, who were directly represented in the state councils, as well as the emerging local traders in Anatolia replacing the minorities, who had to rely on their connections with Ankara. In fact, as Lewis (2002) notes, a class-based conception of society was rejected at the congress, and "[t]he Republican Party, 'the synthesis of the people', was the sole representative of all these groups ${ }^{48}$, the uniting link among them"

\footnotetext{
48 There were four main social groups represented at the congress: artisans, farmers, traders and workers. But their interests were not to be antagonistic. Lewis quotes Mustafa Kemal (Atatürk) on this: "At this moment, my listeners are farmers, artisans, merchants and workers. Any of these can become the
} 
(Karpat 1959, 51-52; also see İnsel 1984, 124-125). In this regard, business people were not to be seen as a separate group that could be represented outside the institutional boundaries of the state.

Indeed, the founding bureaucratic-political cadre of the republic was made up of two competing groups, the liberal wing and what I would call the communitarian wing. The liberal wing was represented by Celal Bayar, an economist and the president of $\dot{I}_{\xi}$ Bankast $^{49}$, who had replaced İsmet İnönü as the prime minister with the support of president Atatürk. The communitarian wing was represented by İsmet İnönü, the second most powerful man of the republic. The disagreement between the İnönü camp and the Bayar camp was not over whether or not the capitalist path of development should be taken, but about the relative positioning of the government policies vis a vis the economically significant groups and economic development efforts (Karpat 1959; Tekeli and İlkin 1982, 339-340). ${ }^{50}$ Decisions from the İzmir Congress had reflected a

antagonist of another. But who can deny that the farmer needs the artisan, the artisan the farmer, the farmer the merchant, and all of them need one another and the worker" (cited in Lewis 2002, 467). As Köker $(1990,185)$ indicates, Mustafa Kemal (Atatürk) was well aware of the disruptive potential of capitalist individualism on society and the tension between the notions of public interest and private interest, which could lead to dissolution of a society already linked weakly in territorial and political terms (İnsel 1984, 126-127; also see Karpat 1959).

${ }^{49}$ A national bank established by Atatürk to support the business sector.

50 The best example of this tension could be found in the conflicts between the laws introduced by CHP governments in different years, sometimes cancelling out the benefits and uses of the previous ones. The conflict between Law \#1055 and Law \#2064 in the case of importing privileges, as well as the reversal of the decisions concerning the legal status (and autonomy) of the state enterprises vis a vis the Bank of Industry and Mining (from a close relationship as set up in the founding law to an autonomous one introduced with the Law of the Office of Industry, which is critisized in the Council's report) (E334 E335), indicate that the policy-making process did not present a coherent picture. Why were there such conflicting laws following each other, even under the rule of a single party, that of the CHP? It can be argued that the struggle between the competing views of those two main groups inside the CHP was the reason behind this. 
more balanced view, alluding to the concerns of both wings. An entrepreneur would be the person with a public responsibility, while national economic policies were to be defined in line with the entrepreneur's interest (İnsel 1984, 182; Yalman 2002, 30). Yet, the balance of power between these two groups was shifted in favour of the communitarian wing at the CHP party congress in 1931 (İnsel 1984, 179) in a context marked by the world economic crisis of 1929 (cf. Günçe 1981, 118-121). The communitarian wing remained in power until 1950.

Under the communitarian wing, the national bourgeoisie was not allowed to organise outside the institutional boundaries of the state. Despite the existence of local chambers of commerce and industry across the country, these elements were not allowed to unify under a separate umbrella organisation. The only activity of national scale that they could undertake was to have annual national congresses. They were not allowed to have standing committees between the congresses. The chambers were under direct control of the ministry of trade (Insel 1984, 150). These restrictions sustained the representational divide between the İstanbul-based capital and the emerging local bourgeoisies in Anatolia by forcing them to use different channels and forms of representation, thereby also cutting off the lines of effective communication and dialogue between these different elements of the national bourgeoisie. While İstanbuland İzmir-based capital were in direct contact with the apex of the state, emerging elements of the Anatolian capital had to communicate through the local branches of the CHP. 
The post WW2 era witnessed significant changes in the relations between the bourgeoisie and the state, as well as between the İstanbul based capital and the local bourgeoisies in Anatolia. There were three important factors behind these changes: a) transition to multi-party rule in 1946 with the establishment of the Democratic Party (Demokrat Parti - DP); b) establishment of the TOB (Türkiye Odalar Birliği - the Turkish Union of Chambers; later the TOBB) as the umbrella organisation of the national bourgeoisie; and c) economic policies pursued by the DP.

The seeds of a multi-party rule were already contained within the CHP, in the form of the tension between the communitarian wing and the liberal wing supported by the İstanbul-based bourgeoisie. Yet, it took two decades for this tension to take politicoinstitutional form, with the split of the liberal wing from the CHP under the leadership of Celal Bayar and Adnan Menderes - another ex-CHP deputy and a wealthy landlord from the Aegean region. A series of domestic and international developments ripened the conditions necessary for such a transition.

On the domestic front, widespread social opposition to the single-party rule of the CHP had been emerging across the country. Despite the fact the landlords were part of the ruling coalition that won the War of Independence the statist policies had inflicted part of the cost of state-led industrialisation policy on the landlords through taxation, while politically marginalising them. This deepened the opposition to the CHP especially in rural parts of the country. In addition, the modernising approach of the CHP had increased the discontent with their secular, top-down approach, on the side of the rather conservative rural population. Second, although Turkey did not actively 
participate in the WW 2, it felt the economic impact. Black markets in certain consumption goods and the extremely high profit margins offered by the war economy led to the emergence of rich merchants across Anatolia, who did not enjoy political influence despite their increasing economic power. Now, there was the nouveau-riche beside the local notables marginalised by the CHP, who sought to enhance their political power. The election results of 1950,1954 and 1957 indicate that the support for the DP came from the wealthier urban sector of the society where the bourgeoisie had started to emerge as a distinct social group (Özbudun 1976, 219; 1980, 60; Çakmak 1985, 251-265; Zürcher 1993, 224-225). Third, there was an increasingly strong İstanbul-based bourgeoisie whose interests increasingly lay with the pursuit of an open economic policy prioritising commercial interests (cf. Dodd 1979), and whose influence over the CHP governments was not enough to initiate radical economic policy changes that would work for them.

Certain international developments provided the final push for the institutionalisation of this social opposition in the form of a political party, and thus for the birth of multi-party rule (Tekeli 1980, 295). Turkey's alignment with the capitalist Western countries against the Communist bloc was the most critical turn in this regard. Turkey's economic strategies were to be re-determined according to the division of labour between the capitalist countries. This involved an increased emphasis on antistatist, open economic policies, and the CHP was already under pressure to implement these changes sought by Turkey's new allies (Karpat 1959; Tekeli 1980; Kepenek and Yentürk 1997, 85; Ahmad 1995, 1554-156; Yalman 2002, 32). Yet, it was the DP that 
wholeheartedly followed this new economic agenda. ${ }^{51}$ According to this new scheme, the role designated to Turkey, with regards to the broader division of labour among the capitalist countries, was to serve as an exporter of agricultural products. Turkey was not to be industrialised. The Marshall plan gave momentum to the modernisation of the agricultural sector, while the Democratic Party heavily invested in major infrastructure including road networks, irrigation projects, etc. to enhance the integration of rural areas to the domestic economy (cf. Önder 2003, 270). The integration process with the Western world also required a radical transformation in the political system as single party rule was the most significant characteristic of the capitalist West's arch enemies, namely Nazism and Communism. This pressure also quickened the transition to the multi-party system, which began with the establishment of the DP in 1946. The DP's political-economic agenda clearly reflected the anti-communist, liberal tendencies of the Western Bloc.

\footnotetext{
${ }^{51}$ As Yalman argues, "the anti-elitist and/or anti-statist discourse of the Democratic Party could be much better understood as being instrumental in the development of a new hegemonic project which attempted to link various particularistic interests under the leadership of an emerging bourgeoisie which had no intention of weakening its ties to the state" (2002: 34). For example, before they came to power, the DP had declared that it would privatize the state enterprises, using the slogan that they would return state enterprises to the nation/people. Yet, this promise was quickly forgetten as soon as they came to power because, now, they were controlling those enterprises on behalf of the nation/the commercial bourgeoisie (cf. İnsel 1984, 192). In addition, the DP followed an active intervention strategy to support the private sector. Following Avcıoğlu, we can discern a variety of intervention strategies pursued by the state during this period: a) provision of cheaper credits, using the financial sources received from foreign sources, which were loaned at rates below the interests rates at which this money capital borrowed from international sources; b) major investment in infrastructure, especially for the creation of a network of roads, which eased the creation of a national domestic market, the building of dams, and the provision of cheap energy to the private sector; c) the training of engineers and managers and transfer of trained, experienced public servants to the private sector; and d) the creation of public-private partnerships (over a hundred) in the industrial sector, where the state was either the senior partner or a stakeholder $(1975,717$ 721; also see Kepenek and Yentïrk 1997, 89-90, 100-101).
} 
Tachau notes that multi-party rule made it possible for parties to organise on the basis of class $(1991,99)$, and the DP represented a coalition of rural landlords, the İstanbul-based bourgeoisie and the slowly emerging local commercial bourgeoisies in Anatolia. This compromise was partly institutionalised under the umbrella of the TOB. As Öncü explains, "the leading Chambers of Commerce, in cooperation with the Ministry of Economy and Commerce, drafted Law 5590, which went into effect on March 15, 1950, about two months before the Democratic Party won the elections. ... the Union ... was instituted and grew in significance during the Democratic Party (DP) rule and became identified with it" $(1980,465)$.

The İstanbul-based commercial bourgeoisie played an active part in establishing TOB as the representative of the national bourgeoisie, and this gave it a chance to establish itself as the spokesperson of the local bourgeoisies of Anatolia. It aimed to legitimise its claims to form and sustain the implementation of an open economic strategy based on commerce and agriculture, while postponing the spread of industrialisation into different corners of Anatolia. It is precisely in this context that we can understand how the İstanbul-based commercial capital influenced the geography of industrialisation in the country. In fact, law \# 5590 allowed the establishment of independent chambers of industry, and: 
as soon as the law [5590] was passed, the existing Association of Industrialists called for an extraordinary meeting of its General Assembly. The debates of this meeting indicate that there existed a clash between the dominating import-export merchants in the İstanbul Chamber of Commerce and the industrialists. Not only did the commercial interests advocate a liberalization of the import regime, but also they favored a predominant place for agriculture as against industry in the strategy of economic development. ... Despite the creation of two Chambers of Industry in 1952, one in İstanbul and one in İzmir, existing private industry at the time was too weak essentially to make its voice heard in the political arena. And 'the laissez-faire economic policies of the DP government made importing such a lucrative business that no one was willing to invest in industry' (Öncü $1980,465) .^{52}$

The following table (2.2.), adapted from Avcioğlu (1975), lends support to our claim that this accumulation strategy almost froze the broader geographical distribution of industrial enterprises across the country, and had regressive effects on certain provinces, thus postponing the emergence of industrial local bourgeoisies across Anatolia.

Based on the 1964 census, the table indicates that the total number of enterprises employing more than 10 workers quatrapled between 1950 and 1963 . This was the case with 8 provinces (including Gaziantep) out of the top18 provinces. Six provinces experienced increase rates lower than the national average. Only 4 provinces experienced faster growth, including Ankara (the capital) and Zonguldak (the mining and steel production centre created by the state investments). İstanbul housed half of those enterprises both in 1950 and in 1963, which indicates that large scale enterprises

\footnotetext{
52 As Kepenek and Yentürk argue, the structure of industrial production began to be oriented towards consumption goods. Another significant feature of the era was the declining level of total industrial investment, especially from 1956 onwards. Kepenek and Yentürk's explanation is that inflated price levels and associated increases in profit margins in trade diverted the capital to those sectors, rendering industry relatively unprofitable (1997: 103).
} 
continued to be concentrated in İstanbul during the reign of the DP governments. And, even this concentration of large scale industrial enterprises in İstanbul was not sufficient to form an industrial bourgeoisie that could oppose the open-market policies of the DP and the İstanbul-based commercial bourgeoisie.

Table 2.2: Changing geographical distribution of industrial enterprises employing $>10$ workers in Turkey between 1950 and 1963

\begin{tabular}{|c|c|c|c|}
\hline Province & Geographical Region & 1963 & 1950 \\
\hline İstanbul & Marmara & $(\sim) 1,264$ & 321 \\
\hline Bursa & Marmara & $(\sim) 213$ & 51 \\
\hline İzmir & Aegean & (b) 209 & 74 \\
\hline Ankara & Inner-Anatolia & (a) 154 & 24 \\
\hline Adana & Mediterranean & $(\sim) 80$ & 23 \\
\hline Balıkesir & Marmara/Aegean & (b) 68 & 25 \\
\hline Aydin & Aegean & $(\sim) 57$ & 14 \\
\hline Eskişehir & Inner-Anatolia & $(\sim) 46$ & 12 \\
\hline Konya & Inner-Anatolia & (a) 46 & 4 \\
\hline Manisa & Aegean & (b) 42 & 16 \\
\hline Gaziantep & Southeastern-A. & $(\sim) 39$ & 10 \\
\hline Zonguldak & Blacksea & (a) 38 & 5 \\
\hline Kayseri & Inner-Anatolia & $(\sim) 37$ & 9 \\
\hline İçel & Mediterrranean & (b) 36 & 13 \\
\hline Samsun & Blacksea & (b) 33 & 14 \\
\hline Ordu & Blacksea & $(\sim) 29$ & 7 \\
\hline Uşak & Aegean & (a) 27 & 2 \\
\hline Sakarya & Marmara & (b) 26 & 8 \\
\hline TOTAL* & & 2,444 & 632 \\
\hline The rest & & 331 & 80 \\
\hline
\end{tabular}

- Average Increase (national): Total 1963/Total 1950 = 4

- (a) = increase is above the average

- (b) = increase is below the average

- $(\sim)=$ increase is the same with the country average

Source: Adapted from Avcığlu (1975, 730). 
The fourfold increase in the number of industrial enterprises across the country came mainly with the transfer of commercial capital to industrial activity. In other words, the fourfold increase in the national average in 13 years does not express the birth of independent local industrial bourgeoisies that could develop a separate identity as industrialists. A study dated 1961, which covered half of the industrial enterprises employing more than 10 workers in Turkey, found that $43 \%$ of the entrepreneurs had previously been involved in commercial activies. Another $13 \%$ had started their industrial businesses by working with their fathers (Avc1oğlu, 1975). The share of those who were ex-workers and thus had knowledge in those sectors was low (20\%). 16\% came from fields other than industry and trade.

To summarise, the accumulation strategy as formulated and implemented by the DP retarded the spreading of industrialisation to Anatolia, which served to protect the compromise between the İstanbul based bourgeoisie and the local business communities in Anatolia, effectively preventing the formation of interests that would oppose the established accumulation strategy. Nevertheless, although the TOB gave the İstanbulbased capital an opportunity to legitimise its claims, it is hard to argue that this development ultimately led to the emergence of the İstanbul-based commercial bourgeoisie as the political leader. Although the TOB was established by the central government in a top-down manner, it was designed as an umbrella organisation which respected the autonomy of local chambers. The central decision-making organs of the TOB were to be elected by all member chambers. In fact, this flexible innerrepresentation structure of the TOB prepared the institutional ground for future clashes 
between the İstanbul-based capital and local bourgeoisies in Anatolia. As indicated, however, sectoral fragmentation of the bourgeoisie was still at a primitive stage. In fact, that sort of a diversification could become possible only with an accumulation strategy change, which began in 1960 and bore fruit in the 1970s, confirming Jessop's insight that interests are defined and crystalised in the context of an accumulation strategy, and thus they are subject to redefinition with accumulation strategy changes.

An important point to emphasise here is that the way in which the DP and the TOB were articulated also influenced the dynamics of future splits and tensions inside the TOB. The TOB also served as an institutional venue where an important part of the social support base of the DP was politically organised, whereby the DP was able to control and organise the actions of local business communities. This connection persisted even after the Coup D'état of 1960 , which led to the overthrow of the DP government. As we shall see later, Adalet Partisi (the Justice Party - AP) inhereted the mission of the DP by reviving organic ties with the TOB and pursuing an aggressive policy of intervention that targeted the intra-organisational politics of the TOB. The end-result of this intensified connection was the increasing vulnerability of party politics to intra-bourgeoisie conflicts and vice versa.

To conclude, the economic problems of 1958 (devaluation of Turkish lira); and the DP's increasing emphasis on the Islamist discourse pitted the DP against the army, university students as well as Kemalist intellectuals. This conflict brought the end of DP rule in with the Coup D'etat of 27 May 1960. 
The rise of planning ideology and the Import Substituting Industrialisation period (1960-1980)

The Coup D'état of 1960 marked a critical turning point in the history of Turkish political economy, altering the nature of the state-bourgeoisie relations and sowing the seeds of future intra-bourgeois struggles that would ultimately led to the emergence of local entrepreneurialism in the post-1980 era. The most significant development was the introduction of a new accumulation strategy that re-determined the axes of interest definition for different elements of the Turkish bourgeoisie. The post-1960 era witnessed the emergence of a protected economic regime, in which industrialisation was explicitly adopted as a state strategy, i.e, the Import Substituting Industrialisation (ISI) strategy, and "planning" as a form of state intervention (Önder 2003, 271). The ideological emphasis on planning located bureaucracy at a more central position in decision-making processes and in implementation of the economic policies. In this regard, the changing form of intervention was associated with significant changes in the internal organisation of the state. A key development was establishment of the State Planning Organisation (Devlet Planlama Teşkilatı - DPT), which was placed directly under the Prime Minister's office, by-passing the existing bureaucratic apparatus of the state. $^{53}$

\footnotetext{
${ }^{53}$ Its responsibilities included preparing and implementing 5-year economic development plans, making public investment decisions, and distribution of state benefits and incentives to the private sector to promote industrialisation (Şaylan 1981; Küçük 1981; Günçe 1981; Tekeli 1981, Barkey 1990, 64).
} 
The roots of this strategy shift could be traced back to the late 1950 s when the DP government had been exposed to pressures from international organisations like the OECD and developed countries to follow a measured state investment strategy. The aggressive, yet unplanned ${ }^{54}$, infrastructural investment strategy of the DP governments and the increasing number of state economic enterprises they established had already started to create huge debts. In the context of an open economic regime, this resulted in a balance of payment crisis, culminating in the crisis of 1958 and the subsequent devaluation of the Turkish Lira (Bulutay 1981; Barkey 1990; Ceyhun 1992; Çilingiroğlu 2003, 22-24; Karaosmanoğlu 2003, 12). As Nejat Erder ${ }^{55}$ affirms, during that period, planning was regarded as an effective approach to the question of economic development by international policy circles $(2003,7-8,10)$. Adoption of economic planning was explicitly demanded by the OECD and Western countries, if the financial aid they provided Turkey with was to continue. Both the CHP and the AP, the heir of the DP, adopted this strategy during the post-1960 period. $^{56}$

\footnotetext{
${ }^{54}$ Çilingiroğlu's account of the difficulties met by the first planning team in gathering the information related to the state investments - in fact the lack of information about those investments - provides a strong testimony to the unplanned and haphazard character of state investment strategy during the $1950 \mathrm{~s}$ (2003, 23-36).

${ }^{55}$ Erder was a member of the team of planners who prepared the first national economic plan between 1960 and 1962, and who founded the State Planning Organisation. Other prominent names were Ayhan Çilingiroğlu, Attila Karaosmanoğlu, and Attila Sönmez who had been involved in the earlier, albeit failed, attempts to prepare a plan during the DP period in collaboration with famous economist Tinbergen.

${ }^{56}$ According to a survey conducted among the MPs, which was published in October 1962 in the national newpaper Cumhuriyet, $67 \%$ of the AP MPs and $75 \%$ of the CHP MPs asserted that "mixed economy" strategy was preferrable to other alternatives. $33 \%$ of AP MPs expressed their support for a liberal economy while 25\% of CHP MPs favoured a socialist economic model (Karaosmanoğlu 2003, 16).
} 
The Import Substituting Industrialisation ${ }^{57}$ (ISI) strategy had its roots in the basic premise that in an environment characterised by unequal terms of international trade, poor countries could develop by developing their own industries. An export strategy relying on natural sources and agricultural products tends to put these countries into a vicious circle as developed countries implement protectionist measures against these products, while their own industrial products can easily find their way to the unprotected markets of these underdeveloped countries. The ISI strategy is offered as a way out of this vicious circle. According to Bruton,

The idea is that by replacing the imports of certain commodities by domestic production, the economy will be so modified that it will begin to be more independent, more resilient, more diversified, and better able to generate increasing welfare as a matter of routine. Replacing the imports of certain individual products by their domestic production is a means to end, not an end itself $(1989,1604)$

In this regard, protection is not to be universally implemented. The restrictions on imports and the sectors are to be carefully selected and framed (cf. 1989, 1605-1604). The ultimate aim is to help industries that could contribute to the spread of industrialisation in other sectors flourish, especially in those sectors producing "producer goods", and to start exporting when domestic industries reach a certain level of maturity, thus balancing out the position of that specific country in international trade.

\footnotetext{
${ }^{57}$ As Bruton summarises, "Import substitution is often 'measured' by a change in the ratio of imports to the total availability (imports plus domestic output) of a single product or category of products. If this ratio falls over time, then import substitution is said to take place in that particular sector" $(1989,1604)$.
} 
In fact, this was the scheme that the first Turkish planning team had in mind. Protection was intended for a few, strategically selected sectors and was to be ended after 8 years. Yet, the economic policies and the 5 -year development plans ${ }^{58}$ followed a different course that ended with a number of policy failures. The most dangerous mistake was to implement a rather universal protection regime, which turned state protection into a considerable source of rent, eventually igniting heated fights inside the bourgeoisie over this source (Sönmez 2003, 39-40). In addition, the strategic producer goods industries remained relatively underdeveloped. The consumer good industries that produced for the domestic market constituted the core of the emerging national industrial structure. This meant a failure to develop an export-oriented industrial structure. As a result, the export-import ratio fell to $30 \%$ in 1977 , worsening the balance of payment problems that already existed (Boratav 2003, 119-121, 134, 140). When combined with an atmosphere of political stalemate, this ultimately led to an economic crisis that paved the way for the Coup D'état of 1980. Thus, the ISI regime did not come as the political project of a strong and conscious industrialist class (Zürcher 1993, 278; Erder 2003, 48), or of a bourgeoisie whose survival depended on industrial production. International pressures and the economic crises of the late 1950s paved the way for this accumulation strategy shift, which was rationalised by reference to the "collective capitalist" role (Öngen 2003, 174) of the state. Thus, although the ISI regime was marked by the hegemonic significance of "industry" (cf. Keyder 1989, 200-203) it

\footnotetext{
${ }^{58}$ In fact, the team that prepared the first plan resigned in 1962.
} 
would take some time before an industrial bourgeoisie, whose survival depended on the promotion of a consciously pursued industrialisation strategy, would emerge.

This shift in the economic regime, and the way in which the ISI strategy was implemented, gave rise to significant changes in the organisational structure and the profit making strategies of the bourgeoisie in general, which in turn would give rise to tensions between the metropolitan large scale capital and the newly emerging Anatolian bourgeoisie in the 1970s. "Industry as a field of economic activity" gained significance and became a major source of profit, thereby paving the way for the rise of industrial capitalists. Yet, the increasing significance of industrial production also created a fragmentation inside the bourgeoisie, ultimately paving the grounds for the current dual structure: smaller scale local industrialists mainly located in the Anatolian cities like Çorum, Kayseri, Denizli, Konya and Gaziantep, and the large scale multi-sectoral holding companies largely concentrated in the İstanbul-Marmara Region.

Especially after the foreign exchange crisis of 1958, mainly İstanbul-based large scale commercial capital turned their previous international trade partnerships into domestic industrial collaborations by establishing factories that undertook final assembly of products that they have used to import (Eralp 1981; Sönmez 1992; Buğra 1994). This meant increased profit rates on the side of large scale capital as they benefited from lower labour costs (cf. Ercan and Tuna 2006) and the protected domestic market. In addition, the multi-sectoral nature of these enterprises gave them superiority in the domestic market, as they could sell what they produced without having to deal with intermediaries, using their existing domestic marketing networks (Ercan and Tuna 
2006). The increasingly multi-sectoral nature of these large scale enterprises also gave them flexibility in responding to economic crises, and a chance to adapt to likely accumulation strategy changes (Avcıoğlu 1976; Sönmez 1992; Buğra 1990; 1994).

The general re-orientation in the national accumulation strategy and the subsequent increase in the profitability of industrial production resulted in the emergence of local industrialists in the Anatolian cities. Their relationship to the accumulation regime was not as flexible as the multi-sectoral İstanbul-based capital, as their livelihood depended upon industrial production. They faced a number of challenges, which could only be overcome with active state support and protection. First, there was not a properly planned division of labour between the large scale capital and these local industrialists. Local industrialists were forced to compete with large scale İstanbul-based capital in their local consumer good markets. Second, unlike their İstanbul counterparts, local industrialists in Anatolian cities did not have international connections. Thus, establishing assembly-based factories was not an option, and there was no available technological support that could contribute to product development. Third, local industrialists also had to compete with the large scale capital over the rents created by the import controls and the scarce resources provided by the state in the form of incentives.

As Barkey states, the ISI regime was constructed using a number of policy instruments: "the import regime, with its complicated [import] 'lists' ${ }^{59}$, overvalued

\footnotetext{
${ }^{59}$ Namely, liberalised list of uncontrolled goods; the Quota list of restricted imports; bilateral trade
} imports, and self-trade imports as alternative arrangements to the Quota list. 
exhange rates, and low interest rates for industry. These features were of great importance to all participants. They represented the source of the economic rents over which private sector groups struggled" $(1990,74)$. In this struggle, too, Anatolian industrialists had a weaker hand, especially in reaching the nodes of economic decision making. As previously noted, the decision-making mechanism had been centralised after the 1960 Coup, through the creation of the DPT. The cautious approach of the central bureaucrats to the individual demands of local entrepreneurs - mainly transmitted through the channel of local politicians and MPs, a characteristic of the DP era - created a representational barrier. In addition, unlike multi-sectoral large scale capital, they did not enjoy visibility and direct access to the political nodes of decision making, namely the government and the Prime Minister (cf. Şaylan 1981; Barkey 1990; Zürcher 1993). ${ }^{60}$

In this context, it became a strategic priority for these local industrialists to bring the problems of Anatolian industrialists to the attention of the state, and to have a say in the formulation and implementation of economic policies, in order to enhance the conditions of local accumulation. The increasing centralisation of decision-making, narrower room for maneuver in domestic markets and the lack of social capital that could have led to informal arrangements between newly emerging industrial

\footnotetext{
${ }^{60}$ Ercan and Tuna (2006) cite two striking instances of this direct access. The first one is the threemonthly meetings between the post-coup government and the representatives of the business community, namely prominent business people, which began in 1962 to shape industrial policy. The second instance is the appointment of the minister of industry. The president Cemal Gürsel called upon TOB to give the names of three candidates for the ministership, and appointed one of them, Şahap Kocatopçu, as the minister.
} 
entrepreneurs forced them to adopt organised political action as a form of representation (cf. King 1983). In particular, business associations constituted a strategic venue of collective action and site of representation. Local industrialists had to wage their struggles at two scales. At the local scale, they had to establish themselves as the dominant voice in their local chambers of "commerce and industry". This meant challenging the superiority of the commercial fraction. As we shall see later, this struggle, which was waged in the Gaziantep Chamber of Commerce and Industry during the 1970s (Öncü 1980), was settled in favour of the industrialists in the 1980s. The second struggle had to be waged at the national scale against the İstanbul-based capital $^{61}$ (Barkey 1990; Öncü 1980, 458-461).

The TOB defined the institutitonal battleground of this struggle, as it was the sole representative of the national bourgeoisie officially recognised by the state. This uprising of the Anatolian capital aimed to redefine the political and territorial reference points of "national" bourgeoisie and national economic interest, in their favour. Thus, the accumulation strategy had to prioritise the demands and concerns of local industrialists who were located in the Anatolian cities, and had to fully operationalise the ISI regime, which was being slowly corrupted, by redressing the geographical unevenness of economic development and industrialisation. ${ }^{62}$

\footnotetext{
${ }^{61}$ In fact, the tension between local industrial bourgeoisies and local commercial bourgeoisies were not independent from the struggle between the İstanbul based capital and the local industrial bourgeoisies. The local commercial bourgeoisies' interest mainly lied in maintaining good relations with the İstanbul based large scale capital, as their commercial activity relied on selling the consumer goods produced by this large scale capital (cf. Ercan and Tuna, 2006), which were sold at the local markets.
} 
To make better sense of the political dynamics behind the implementation of the ISI strategy, and the intra-bourgeoisie struggles it gave rise to, we need to discuss who implemented those policies, and with what sort of considerations in mind. A brief look at the political scene of the era indicates that it was mainly the Justice Party of Süleyman Demirel - Adalet Partisi (AP), which held the upper hand in forming national governments (Table 2.3). The AP, as the ideological successor of the DP, came to office in 1965. It was able to garner the support of all fractions of the bourgeoisie during its first term in office (1965-1969). In addition, via its connections with Türk-İş (the largest umbrella organization of trade unions in the country) and by having workers in both the party's representative structure and in the parliament caucus, the party was able to present itself as the hegemonic leader of the country for a short while. As Levi notes,

${ }^{62}$ One striking instance of this concern was the removal of the term "regional planning" from the implementation plans of the DPT in 1966 (Keles 2002), the year after Demirel's AP, the heir of the DP, came to power. According to the AP, the perceived danger had two aspects: First, official recognition of "regions" could give a stronger hand to the contending political-economic groups as a source of identity that could eventually create another axis of political struggle (a nightmare which Demirel eventually faced in the case of the TOB regardless); secondly, the notion of "planning" was the ideological boogeyman of the AP, as the inheritor of the DP.

The state planning organisation's response to uneven development was to give priority to the underdeveloped parts of the country while location decisions for direct public investments were made. Yet, it is not possible to argue that these decisions were of help in remedying the problem. Tekeli (1981), employing empirical evidence, finds that even the public investments tended to be concentrated in developed regions, like the İstanbul-centred Marmara region, even despite the decisions to privilige the underdeveloped regions in that regard. The decisions concerning regional development were incorporated into the national plans after they were prepared, to be able to respond to the criticisms of MPs (Tekeli 1980). The national development plans were macro decisions in nature, and the spatial dimensions of these main economic decisions (other than public investments) were not taken into consideration (Günçe 1981, 124). 
The JP [AP] was for social justice but, in the words of Demirel, this did not mean equality in poverty, hostility to capital or equal distribution of income. The way to achieve social justice did not pass through class struggle but through a real increase in the national income. ... Thus, it was imperative to have economic growth first. This required collaboration and harmony among different social groups. Such harmony could be provided by melting particular interests into the national one $(1991,140)$.

In other words, Demirel tried to establish this harmony by prioritising a corporatist scheme of representation, and he benefited from the advantages of controlling a centralised decision-making process. ${ }^{63} \mathrm{He}$ worked in close collaboration with the national representatives of various social groups, and thereby aimed to maintain their loyalty, while also using populist distribution schemes (Boratav 2003, 123-126). In this respect, the TOB constituted an important target of intervention for Demirel's Justice Party. To control the TOB, and other representative organisations of different sectors of the economy, Demirel's Justice Party adopted a number of measures, which involved

a significant expansion of the already substantial privileges and economic activities of the public associations, including new provisions for their direct participation in industrial production. [In addition] ... important new restrictions were placed on the political activities of voluntary associations in order to inhibit uncooperative and dissatisfied interest group leaders from exploiting noncorporatist channels of representation and forming alliances with opposition parties (Bianchi 1984, 142).

\footnotetext{
${ }^{63}$ Here, we have to note that the use of this centralised decision-making powers partially through the DPT, did not mean adoption of a planned approach to economy. In fact, the AP was able to curb the power of the DPT during its rule, and the potential resistance that could come from its experts to the AP's populist policies (Şaylan 1981; Levi 1991). According to Yalman, what was aimed at was "de-link[ing] planning from its étatiste heritage" (2002, 36; cf. Turan 2003, 138).
} 
By controlling the TOB, and distributing import quotas through the TOB and the local chambers under its umbrella, Demirel acquired an important bargaining power over the local industrialists and the business people in general. The implication of this approach was the increasing dominance of the logics of influence and implementation. This tended to lessen the significance of local chambers and the opposing forces within the TOB, creating a pressure on them to remain in line with the AP's policies. Yet, this scheme eventually collapsed, mainly because of the changing profile of the membership.

The foundational law had made it compulsory for every trader and industrialist to become a member of its local chamber in order to be recognised as a legal enterprise. This meant that any socio-economic transformation taking place in the country would inevitably find its reflection in the membership structure of those local chambers, and thus the TOB. This profile change was characterised by the rise of local industrialists and the emergence of an ever stronger large scale capital that would soon be able to assert itself as a unified and independent political power. ${ }^{64}$ This meant the rise of the logic of membership within TOB, and within the local chambers, by defying the superiority of the logic of influence.

\footnotetext{
${ }^{64}$ In fact, Demirel's AP had maintained good ties with the local commercial bourgeoisie and the farmers. Initially, the large scale was also part of this front. As already noted, the large scale multi-sectoral capital had relied on local traders to sell their industrial goods. Moreover, as Ercan and Tuna (2006) notes, this local commercial bourgeoisie who served as the middle-man of İstanbul based producers, such as Koç, were also serving as the top names of the local branches of the Justice Party. According to the authors, it was usually the traders selling the products of Arçelik - the durable goods brandname of the KOÇ group who served as the leaders of the local party branches.
} 
The end result of the clash between these two logics, and the intra-bourgeoisie struggles it was intertwined with, was organisational splits ${ }^{65}$, and displacement of the intra-bourgeoisie struggles to the arena of party-politics. An institutional design aiming for a hierarchical and corporatist system of representation logically requires a stable political power capable of co-ordinating the demands and compromises. Once relations with this single authority are severed, or when this overseer authority weakens or becomes multi-headed (as was the case with the coalition governments of the post-1971 era) then transmission of the tensions from the sphere of party politics to the business world (or vice versa) becomes easier. This was precisely the case during the 1970 s in Turkey when the state itself constituted the greatest source of uncertainity for the firms (Buğra 1990). According to Ramazanoğlu,

\footnotetext{
${ }^{65}$ As of 1977 , "there were 8 chambers of Industry within the rubric of the union [TOB], 131 Chambers of Commerce and Industry, 50 chambers of commerce, and finally 52 commodity exchanges" (Öncü 1980, 458) in Turkey. Yet, establihment of independent local chambers of industry was not welcome. As long as the local commercial bourgeoisies were concerned, the weakening of their credibility as the sole representative of the 'local bourgeoisie', and the loss of considerable financial sources and the state benefits in case of a split, made the establishment of an independent local chamber of industry a very delicate and conflictual matter. The leading cadre of TOB working closely with Demirel also resisted the establishment of independent chambers of industry. In fact, as Barkey observes, out of their opposition to Demirel's policies, the chambers of industry even considered the leftist CHP of Ecevit, despite the likely dangers they perceived from the working class supporting this party (Barkey 1990).
} 
the internal contradictions of the Turkish bourgeoisie were ... sharp and intractable [and] The crux of the problem was that the uneven development of capitalism had given undisputed economic power to the dominant fractions of the bourgeoisie, i.e. monopoly/industrial and financial capital, but this power was being challenged, and challenged effectively, by those who were not going to benefit from an outward-looking economy. The parliamentary system ... became the most important factor for perpetuation of this non-correspondance between the economic and political levels. Demirel found himself caught between promoting the interests of monopoly/industrial and financial capital and retaining his electoral base, of landed interests and small businesses, where capitalist production was much less highly developed (1985b, 86-87).

The rise of Necmettin Erbakan's National Order Party - Milli Nizam Partisi ${ }^{66}$ was an expression and end-result of this fight (see Barkey 1990; Levi 1991). Erbakan has been an ardent promoter of Anatolian capital, with a vision of 'heavy industrialisation movement'. His discourse had a political Islamist tone, accusing big capital of being in collaboration with the 'Capitalist West', while seeing Anatolian capital as the real actors of 'National Development'. ${ }^{67}$ Erbakan seized upon the gap between the expectations created by the ISI and the demands of the Anatolian industrialists. Erbakan benefited from two tensions inside the TOB: 1) the perceived representational weakness and discontent of the industrialists: especially given the gap between the discursive significance of industrialisation strategy and the industrialists' lack of voice in the shaping and implementation of this strategy; and 2) Anatolian capital's discontent (Barkey 1990, 150-151): In the 1969 TOB elections, Erbakan was

\footnotetext{
${ }^{66}$ After the 1971 military memorandum, it was replaced by National Salvation Party - Milli Selamet Partisi - MSP.

${ }^{67}$ The MSP - and its successors - called themselves as the 'National Vision Movement' (Milli Görïşs Hareketi).
} 
elected as the general secretary of the TOB by the rebelling TOB members. In response, Demirel withdrew the import quota allocation privileges previously assigned to the TOB. Demirel's government also changed the semi-public status of the TOB, delegitimising it as a representative of business. This move frustrated the Anatolian industrialists, and eventually pushed Erbakan into the political arena, first as an independent MP in the 1969 national elections, and then as the leader of the National Order Party in 1970 (Barkey 1990, 152-153).

Just like the DP's earlier separation from the CHP, Erbakan's MSP emerged from within the ranks of the Justice Party, as a result of the changing political power of the bourgeoisie in Turkey. Erbakan's movement was never able to capture the control of the government as the governing party. Indeed, Erbakan's radical Islamist discourse restricted the ranks of his movement to the industrialists of conservative Anatolian cities, such as Konya and Kayseri, thereby preventing the emergence of his party as a true, national representative of all Anatolian industrialists. ${ }^{68}$ Nevertheless, seizing upon the opportunities created by an unstable political atmosphere, Erbakan's party played a key role various coalition governments and had a considerable influence on implementation of economic policies. ${ }^{69}$ The posts his MSP controlled included

\footnotetext{
${ }^{68}$ For example, Gaziantep was a stronghold of the CHP, which was a secular party. Indeed, industrialists were symphatetic with Ecevit's CHP, whose approach to economic policies resonated with the demands of the small industrialists, and with Erbakan's national view approach, for the protection of Anatolian industry and for fair implementation of the ISI strategy. In fact, the first organised industrial district in Turkey was established by the state in Gaziantep when Ecevit's CHP was in power.

${ }^{69}$ Caught by the parliamentary principle of majority rule, two major parties of the country, Demirel's AP and Ecevit's CHP -arch enemies- had to turn to Erbakan's MSP to form a coalition. Enjoying the strong bargaining power, Erbakan was able to collaborate with both parties at different times, and thus stayed in power for a considerable period of time during the 1970s.
} 
ministries of industry and trade, finance and state ministries responsible for economic coordination: "Erbakan and the NSP [MSP] used the Ministry of Industry to deny state incentive certificates to projects in the West, specifically in the Marmara region [which includes İstanbul]. After two years of co-existence within the same government, the JP and NSP failed to agree on the location of a single project" (Barkey 1990, 157, 160, emphasis original).

Indeed, along with the Anatolian industrialists, the İstanbul-based capital was also frustrated by Demirel's move to use the state benefits as a means of punishment. Disappointment with Demirel, the rise of worker activism, and the opposition coming from the Anatolian industrialists forced the İstanbul-based large scale capital to unify under a new business association that would defend its collective interests, the TÜSİAD (Türkiye Sanayici ve İşadamları Dernegi - The Industrialists' and Businessmen's Association of Turkey). The TÜSİAD was established by the leading holding companies of the country in 1971 following the military intervention, which forced the AP government to resign. Large scale capital chose to support the military rule in the hope of maintaining political stability (Levi 1991). Unlike the TOB, the TÜSİAD's legal status was not public, although it would gain a semi-public status after the Coup of 1980. It was a private lobbying association whose actions were informed by the 'logic of membership'. The creation of the TÜSİAD helped large scale capital to define its own interests as above political conflicts and beyond politics, by emphasising the TÜSİAD's role as a true representative of 'national interests' that cannot be promoted 
through political factionalism or partisan politics ${ }^{70}$ (Sönmez 1992, 150-153; Bianchi 1984, 259-271; Barkey 1990, 112). This was an explicit political move by large scale capital to produce and dictate a hegemonic economic vision, outside the political and institutional boundaries of the state for the first time in the history of the republic. Due to legal obligations, TÜSİAD members retained membership in the TOB. Nevertheless, the TOB had lost its significance for large capital as a channel of representation, and it became the site of representation of smaller scale capital of Anatolia. It is, however, hard to argue that the TOB was under the complete control of the Anatolian industrialists. Erbakan's move to establish a political party to promote their cause, under the banner of an Islamist discourse, indicates that the TOB was also losing its significance as a site of representation for the Anatolian industrialists. ${ }^{71}$

Political mobilisation remained the only option for emergent local bourgeoisies in a context characterised by severed relations with the apex of the state, the reign of unstable coalition-governments during the $1970 \mathrm{~s}^{72}$ (Table 2.3), and the continuing

${ }^{70}$ Its involvement in politics reached an apex in 1979 when it helped to bring down the third Ecevit (CHP) government

${ }^{71}$ In fact, founders of TÜSİAD, too, established a second representative association outside the institutional boundaries of TOB, specifically to defend their interests in the industrial sector, namely the TiSK (Türkiye İşveren Sendikalari Konfederasyonu - The Confederation of Employers' Unions of Turkey). As an employers' organisation, its class character was more pronounced. According to Sönmez, after the late 1970s, however, the group dominating the TÜSİAD lost control over the TISK especially after the coming of medium-scale industrialists. Contradictions between the TÜSİAD and the TISK emerged around the strategies to be pursued in the face of rising demands from the workers, with the former adopting a more positive and compromising stance, while the latter took a more combative approach $(1992,161)$. Unlike the Anatolian industrialists, members of the TISK adopted the national, rather than the local, as the scale of organisation and representation. Local employers' associations (in İstanbul, for example) were dissolved and unified into the TISK as a national organisation in 1962, following the proposals of an OECD representative, Lennart Landquist, previously serving under the Swedish Confederation of Employers (Sönmez 1992, 160). 
significance of the state as the most important provider of benefits that the Anatolian

industrialists needed.

Table 2.3: Central Governments in Turkey between 1960 and 1980

\begin{tabular}{|l|l|}
\hline Service Periods & Cabinets formed \\
\hline $30.05 .1960-05.01 .1961$ & I. Gürsel Government (military-transition) \\
\hline $05.01 .1961-20.11 .1961$ & II. Gürsel Government (military transition) \\
\hline $20.11 .1961-25.06 .1962$ & VIII. İnönü Government \\
\hline $25.06 .1962-25.12 .1963$ & IX. Inönü Government \\
\hline $25.12 .1963-20.02 .1965$ & X. Innönü Government \\
\hline $20.02 .1965-27.10 .1965$ & Ürgüplü Government (technocrat) \\
\hline $\mathbf{2 7 . 1 0 . 1 9 6 5 - 0 3 . 1 1 . 1 9 6 9}$ & I. Demirel Government \\
\hline $\mathbf{0 3 . 1 1 . 1 9 6 9 - 0 6 . 0 3 . 1 9 7 0}$ & II. Demirel Government \\
\hline $\mathbf{0 6 . 0 3 . 1 9 7 0 - 1 2 . 0 3 . 1 9 7 1}$ & III. Demirel Government \\
\hline 12.03 .1971 & Military Memorandum \\
\hline $26.03 .1971-11.12 .1971$ & I. Erim Government (technocrat) \\
\hline $11.12 .1971-22.05 .1972$ & II. Erim Government (technocrat) \\
\hline $22.05 .1972-15.04 .1973$ & Melen Government (technocrat) \\
\hline $15.04 .1973-26.01 .1974$ & Talu Government (technocrat) \\
\hline $26.01 .1974-17.11 .1974$ & I. Ecevit Government \\
\hline $17.11 .1974-31.03 .1975$ & Irmak Government (technocrat) \\
\hline $\mathbf{3 1 . 0 3 . 1 9 7 5 - 2 1 . 0 6 . 1 9 7 7}$ & IV. Demirel Government \\
\hline $21.06 .1977-21.07 .1977$ & II. Ecevit Government \\
\hline $\mathbf{2 1 . 0 7 . 1 9 7 7 - 0 5 . 0 1 . 1 9 7 8}$ & V. Demirel Government \\
\hline $05.01 .1978-12.11 .1979$ & III. Ecevit Government \\
\hline $\mathbf{1 2 . 1 1 . 1 9 7 9 - 1 2 . 0 9 . 1 9 8 0}$ & VI. Demirel Government \\
\hline 12.09 .1980 & Coup D'état \\
\hline
\end{tabular}

Source: Erim (1990, 391-392) and www.tbmm.gov.tr/hukumetler.htm .

\footnotetext{
${ }^{72}$ A striking evidence of this instability is the technocratic governments formed under the pressure of the military, which led to resignation of elected governments. Twenty different governments were established during the twenty year period (1960-1980), whose beginning and end were marked by two coups. It was Demirel and his AP that ruled the country for almost 9 years, almost half of the period. Here, we should stress that the technocratic governments and the military transtion governments ruled the country for around 5 years, and İnönü's CHP for 4 years (again still serving as a transition government backed by the support of other parties), leaving around three years for Ecevit's CHP (Table 2.3). Levi (1991) maintains that the weight of the military, as well as the increased role of the bureaucracy and the constitutional court, created a dispersed decision-making structure, especially during the $1970 \mathrm{~s}$, or in Demirel's terms: 'government by the many', in which the elected government was just one of the actors.
} 
Yet, party-politics was not the best channel and form of political mobilisation. In this regard, the logic of membership led the local industrialists ${ }^{73}$, to turn their attention to their local chambers as sites of representation and vehicles of interest promotion, especially towards the end of the 1970 s. As we shall later see, 1977 was the year when the group that turned the Gaziantep Chamber of Commerce and Industry (later split into separate chambers of commerce and industry) into a powerful and politically motivated representative of Gaziantep's bourgeoisie came to the office.

Here, however, we should note that the local chambers did not represent all entrepreneurs of their locality. Despite the fact that they slowly came to dominate the local policy-making scene and emerged as the major representatives of their local business communities, the petty bourgeoisie, or "Esnaf" ${ }^{74}$, were marginalised during this re-scaling of the local bourgeoisie's representation. Esnaf has had a mobilisation potential due to the historically solidaristic informal networks they possess, and to their size as a social group. Nevertheless, from the 1970s, they remained silent, and were thus increasingly marginalised in both national and local politics. There are four factors that

\footnotetext{
${ }^{73}$ Especially those fractions of local bourgeoisie whose interests lay in promoting their own local accumulation strategies outside the influence and control of the İstanbul-based large scale capital i.e, not as the retailers of the İstanbul based industries' products, or as their sub-contractors.

${ }^{74}$ In Turkish, the term 'Esnaf' is employed in two ways: First as a rather generic term, especially in daily language, to refer to the owners of micro-enterprises, be in trade, service sector or artisanry; and secondly specifically to refer to those involved in trade and service sectors, excluding artisanry. In the initials of the TESK, it bears its second meaning. In the text, I will be using with its first meaning in mind, main reason being theoretical though. Their legal definition as 'enterprises mainly relying on the entrepreneur's labour' and their flexibility in shifting their area of activity allow us to use the term Esnaf to refer to both tradesmen and artisans.
} 
have kept Esnaf at the margins of the intra-bourgeoisie conflicts: a) Given their economic insecurities, they have constituted the section of the bourgeoise most vulnerable to political intervention ${ }^{75}$ (Bianchi 1984, 248; Weiss 1988) ${ }^{76}$; b) The institutional and legal separation of Esnaf (micro entrepreneurs, be artisan or pettytrader) from other sections of the bourgeoisie especially through the creation of a separate umbrella organisation for Esnaf, the TESK (Türkiye Esnaf ve Sanatkarlar Konfederasyonu - The Confederation of Tradesmen and Artisans of Turkey); c) The dominance of informal relations as a form of collective action over formal (and political) organisation; and d) The representational structure of Esnaf associations, which has created a rather dispersed organisational setting characterised by the dominance of the "logic of membership", thereby hindering the formation of the local

\footnotetext{
${ }^{75}$ Moreover, individual SMEs rarely possess a capacity to communicate with the state or to benefit from the resources supplied thereby. This is true even when universally applied - and equally open incentive/subsidy schemes are implemented by the state, as Abdullah's $(1999,89)$ empirical investigation of Malaysian SMEs indicates.

${ }^{76}$ Having a conservative background as members of the middle class, their support would mainly go to the right-oriented parties like Demirel's Justice Party (Bianchi 1984, 248-251; cf. Yalkın 1999), which, benefiting from the Esnaf's economic vulnerability, established their relations with the Esnaf on paternalistic grounds. This weakness has structural roots in legal definition of Esnaf. The first attempt to define Esnaf and to distinguish them from traders was made by article 17 of Turkish Trade Law \# 6762 passed in 1956 where it was ruled that "be [they] mobile or permanent in a shop or on a certain location of a street, owners of art and trade whose economic activity relies upon bodily work rather than cash capital, and whose income is small only as to suffice for them to live on are not merchant" (quoted in Altuğ 1999, 30-31, emphasis added). The foundational law of the TOB, Law \# 5590 dated 1950 also emphasised the distinction between Esnaf, and Traders-Industrialists, in a similar manner: Having described who 'Traders' and 'Industrialists' are in articles 3 and 4, it is prescribed that those who do not fit in those descriptions are to be considered as Esnaf $(1999,31)$. Ironically, both laws defined Esnaf not on the basis of who they are, but "who they are not", with an aim to restrict the constituency of the TOB to relatively stronger section of the bourgeoisie. In fact, if an entrepreneur became successful in her/his business, then, her/his status could be upgraded from Esnaf to Trader/Industrialist. In that respect, there is one thing to add: legally, an entrepreneur can not become a member of both the TOBB and the TESK. If there is disagreement over the status of an entrepreneur, a local board formed under the provincial prefect's office decides under which institution an entrepreneur has to be registered (Altuğ 1999).
} 
Esnaf into a unified political front. As we will see, these factors kept the local Esnaf from being vocal in formulation of local policies in the case of Gaziantep, too, despite the fact that they contributed to the employment and economic dynamism of the city and served as a buffer mechanism against social and economic crises.

The military coup of 1980 and the subsequent accumulation strategy shift further contributed to the emergence of local business associations as powerful players in local political-economy, and as political representatives of the local bourgeoisies and their localities. The first important move, in this regard, was de-politicisation of the TOB, by prohibiting the official representation of the TOB's leaders (and of other civil society organisations) in the Turkish parliament and outlawing the intervention of political parties in elections of the TOB (cf. İsbir 2003, 197). In addition, withdrawal of the state benefits earlier provided through the channel of the TOB, decreased its significance as a site of representation.

\section{Rise of neoliberalism and Gaziantep's bourgeoisie (the post-1980 era)}

1980 marked a critical turning point in Turkey's political-economic history. First, a new economic regime was introduced, replacing the Import Subsituting Industrialisation (ISI) strategy. Known as the "measures of January 24", this set of "roll-back" (Peck and Tickell 2002) measures imposed by the IMF envisaged a liberalised, open market economy. Privatisation and New Public Management became dominant discourses of public sector reforms (Aksoy 2003; Güler 1996). Protection of domestic industries 
ended and the currency regime was liberalised. The balance of payments crisis, the product of an improperly implemented the ISI strategy (Boratav 2003), had made Turkey vulnerable in financial terms, and increased its dependency on the IMF. Thus, prescriptions of the IMF were translated into the policy measures of January $24 .^{77}$ At the same time, the unstable political atmosphere of the country made it quite difficult to implement these measures. Not surprisingly, approximately 8 months later the second coup was staged. The Coup D'état overthrew the government, and brought the end of leftist mobilisations that had taken root within a growing proleteriat and the squatter areas of rapidly industrialising cities, as well as the middle class. The early 1980s witnessed the suppression of labour's rights as well as the de-politicisation of society via denial of the political rights of organisation, demonstration, strike, etc. This greatly served the interests of the capital in general by removing a major ideological rival and by considerably suppressing real wages between 1980 and 1988 .

The military junta banished the active political parties and introduced a 'technocratic' government led by a former army general, Bülent Ulusu. Military rule lasted for three years. Most important of all, the government established by the military regime immediately put the economic measures of January 24 into effect. Turgut Özal, who had devised the measures of January 24 as the top bureaucrat of the economy, later served, first, as the minister of economy in the transition government, and then as the Prime Minister, after the elections of 1983. Özal himself established a new right-

\footnotetext{
${ }^{77}$ For a rich and in-depth account of this transformation, especially for the 1981-1992 period see Boratav et al. (1995).
} 
oriented party (the Motherland Party) that introduced liberal reforms in economy, promoting a pro-business, anti-labour political atmosphere in the country, strengthening the ideological pillars of the new neoliberal hegemony. ${ }^{78}$

These tectonic changes have been felt in all aspects of the state (as form) in Turkey, i.e, forms of representation, intervention, and internal organisation, and left strong imprints on the fate of Gaziantep's political economy. In this section, we mainly focus on the economic picture of the transition, and thus, the changing form of state intervention. The first thing to note here is that such a radical change in the national accumulation strategy could not be accomplished without an enhanced capacity for making decisions and implementing them. The military government paved the way by bringing political stability to the country. The next step was to re-scale the decisionmaking powers, especially in economic policy, to the post of the prime minister. Not surprisingly, Prime Minister Özal, an old bureaucrat with a DPT background, further centralised the decision-making powers, while creating new and specialised agencies to implement his government's economic policies. We will discuss the implications of this re-scaling for the representation of the Gaziantep's bourgeoisie in subsequent chapters.

Boratav et al. identify three sub-periods regarding the post-1980 transformation of the Turkish economy, which influenced the prospects of economic development of Gaziantep:

\footnotetext{
${ }^{78}$ The party stayed in power from 1983 to 1991
} 
The first phase [1981-1983] is the 'military' phase characterized by anti-labour income policies enforced by wage suppression, emphasis on stabilization following on the footsteps of the 1980 shock-treatment, deregulation of of internal commodity markets and premature moves into financial liberalization leading to financial scandals.

The second phase [1984-1988] - perhaps excluding the year 1988 - can be labeled as the 'golden years of MP'. The institutional and legal instruments inherited from the military period for controlling labour incomes were used effectively. Expansionary fiscal and monetary policies starting in 1985 with a public investment boom led to the virtual neglect of stability objectives. On the other hand, decisive moves towards trade and financial liberalization were taken.

The third phase [1989-1992] can be labeled as 'return to conventional populism plus external financial liberalization'. A wage explosion accompanied by higher agricultural prices lead to further detoriation of public sector accounts. Privatization is seen as a substitute for fiscal reform. Short-term capital movements in response to relations between exchange and interest rates create erratic changes in balance of payments $(1995,3-4)$.

Of these sub-periods, the first two prepared the ground for the rapid industrialisation of Gaziantep. In fact, as we shall see later, Gaziantep's industrialists confirm that the 1980s were their golden years. This process led to the birth of a stronger industrial bourgeoisie in Gaziantep, which, by 1989, was mature enough to establish itself under the umbrella of a separate chamber of industry.

In particular, two important policy choices of Özal's ANAP (Motherland Party) influenced the post-1980 local accumulation strategy in Gaziantep: the export orientation and, to support this strategy, the use of state incentives, subsidies and credits given to the entrepreneurs on individual basis, rather than Keynesian-oriented and territorially defined state programs. Export-based economic development was the 
'motto' of Özal's ANAP (or Motherland Party) (Şenses 1990). ${ }^{79}$ The export strategy was based upon labour intensive sectors, such as textiles. This strategy, and the suppressed wage levels, worked to the benefit of Gaziantep where the small and medium enterprises had dominated the scene of industrial production. In addition, the strong trade relations (including smuggling) that Gaziantep had with Middle Eastern countries helped the city to adapt to the export regime quickly. Of course, this open economy policy had some drawbacks for the local commercial sector, which also started to transfer capital into the industrial sector. State incentives, subsidies and credits gave a further momentum to the post-1980 industrialisation of Gaziantep, especially from the late 1980 s onwards (see Chapter 3).

The political mobilisation of Gaziantep's bourgeoisie, which will be analysed in detail in later chapters, came in the 1990 s, when the local accumulation process started to be seriously threatened by an unstable national political-economy. Yeldan (2001) indicates that the following years (post-1992) were marked by crises (also see Peck and Tickell 2002, 391). The bubble burst in 1994. The period from 1995 to 1997 saw a return to growth financed by short-termed capital sources. Then, the Turkish economy was hit by the contraction of demand due to the world financial crisis in $1998 .^{80} 2001$ was the year of a domestic economic crisis, this time ignited by a political tension (the

\footnotetext{
${ }^{79}$ There were a number of problems with this strategy. Despite the increasing share of industrial goods in export, to the disadvantage of the agricultural sector, this drive was an unsustainable one (Taşkın and Yeldan 1996, 155). Senses and Kırım (1991) observe that the export boom was mainly due to the revitalisation of idle capacities, rather than industrial investments (cf. Taylor 1990, 270).

80 Yeldan's analysis stops in 2000 with an analysis of the stabilization program of 2000 where he observes that the program would not work, as examplified by the harbinger crisis of November 2000 .
} 
tension between the president and members of the government), which created a political-economic deadlock. This deadlock was eventually overcome with the defeat of all parties previously residing in the parliament, and by the coming to power of a new party, the AKP and the re-shuffling of all members of the parliament.

Suppression of the labour activism, as well as the pro-business political atmosphere of the post-1980 era, turned business associations into one of the few legitimate channels of representation of local concerns to the state. Thus, local business associations' credibility in local politics was considerably increased. Yet, it was the crisis-ridden atmosphere of the 1990s and early 2000s which defined the context of mobilisation of business associations in Gaziantep, as key local political actors. This atmosphere pushed Gaziantep's bourgeoisie to pursue more proactive strategies of representation. The openness and export orientation of the new economic policies, along with the crises mentioned above, led Gaziantep's bourgeoisie to re-scale the local accumulation strategy and pushed the local business associations in search of new interlocutors to facilitate this re-scaling process. Gaziantep's industrialists and traders turned towards the Middle East, first, in an attempt that ended with frustration following the Gulf War. Their attention then turned to the old Soviet Republics, which emerged as a new market in 1991. This market, however, collapsed with the Asian crisis of 1998. We claim that such instabilities compelled Gaziantep's business associations to seek stable markets and politically stronger interlocutors. In this respect, the European Union provided one of the best extra-local (and supra-national) actors and sites for collaboration and interest representation. In fact, Turkey's Customs Union agreement 
with the EU, signed in 1995, paved the way for construction and activation of this strategy of the business associations. In this re-scaling strategy, the national-political agenda promoting the goal of integration with the EU (as a national strategy) played a supportive role in this re-scaling strategy of Gaziantep's business associations.

Nevertheless, national politics and domestic economic strategies pursued by different post-1980 governments were not conducive to the emergence of a coherent and healthy industrialisation process in Turkey and in Gaziantep. In fact, during the period from 1980 to 1996 , the manufacturing investments at the national level declined. Public and private investments targeted the sectors of energy, communication, housing and construction, which initiated the urbanisation of capital in Turkey (Şengül 2001; Altıok 1998, 262). Indeed, as Öniş (1995) suggests, the party system would not allow the establishment of a conscious export strategy favouring specific sectors. The populist orientation in politics, and the lack of an explicitly defined policy preference encouraged various sectors to get more involved in politics, to put more presssure on politicians, and to search for new ways of political representation. As we shall see in detail in the following chapters, organised business lobbying, and especially large scale national business associations, was not favourable to the neoliberal heir of the military government, Özal governments, as a form of representation either.

Özal's negative approach to organised business representation, along with the structural changes in the economy including further centralisation of decision-making in economic policies, resulted in a re-balancing of the power relations between different fractions of capital, once again, to the disadvantage of the industrial capital, while 
favouring commercial and financial capital (or rather the rent-seeking capital) (Öngen 2003, 185; Boratav et al. 1995, 5-6; İlkin 1992). In addition, the increased profit margins in rent-seeking economic activities, such as land-development and banking, decreased the popularity of "industry", making it as a rather risky field of investment, given the lowered profit margins caused by the abolishment of the "ISI regime". As Boratav suggests

\begin{abstract}
A bird's eye view of the policies during the 1980s demonstrates clearly that almost in all these areas the new economic measures have favoured commerce vis a vis industry and agriculture. ... even when compared with the exceptional crisis year of 1979 and disregarding major subsidy elements and so forth, the 1980 s show a distinct improvement in the relative economic position of commercial capital in Turkey $(1990,223)$.
\end{abstract}

These domestic conditions pushed Gaziantep's bourgeoisie, and especially the industrial capital, to pursue a more active and re-scaled representation strategy, and to attach increased significance to national politics. This involved, as we shall see later, a revitalised attempt to re-define what "national interest" means and who constitutes the "national bourgeoisie" at the level of discourse, and organising an Anatolian coalition against this dominance.

\title{
Conclusion
}

In this chapter, following the insights from our theoretical discussions, we explored the roots of the current rise of local entrepreneurialism (under the leadership of the local 
bourgeoisie) in the pre-neoliberal era, during which the national capitalist state has been the most important site and actor of regulation and coordination of the politicaleconomy. We saw that the economic vision of the early republic, and the associated state policies, sustained the uneven geography of capitalist accumulation as inhereted from the Ottoman Empire, and slowed down the spread of industrialisation to the rest of Turkey, thereby creating the basis for a future divide between the İstanbul-based capital and the Anatolian capital. The influence of the İstanbul-based bourgeoisie in the formation of national economic policies was an important factor behind this. Yet, a national accumulation strategy shift, namely the introduction of the Keynesian Import Substituting Industrialisation strategy, implemented between 1960 and 1980, actually fleshed out and translated this divide into an intra-bourgeois struggle, and thus to the activism of local bourgeoisies in Anatolia. In this regard, we problematised the fragmentations this national accumulation strategy change created inside the bourgeoisie, as well as the challenges it posed for the - then - existing forms and channels of representation.

An important lesson that could be derived from the analysis of these dynamics was that accumulation strategy changes and the associated re-structuring and re-scaling of the state forms of intervention and internal organisation compelled different social actors, and in our case the local industrialists and bourgeoisie of Anatolia, to seek new forms and sites of representations, and to develop representation strategies, accordingly. Here, the transformation of the local bourgeoisie activism of the 1970s into local entrepreneurialism during the late 1980s and early 1990s should be understood in this 
sense. In this chapter, especially of interest to us was the changing role and place of the business associations in the representation of the local bourgeoisie, and especially for its industrial fraction. We saw that the intra-bourgeoisie struggles of the 1970s, and the associated political and economic crises, increased the significance of local chambers for the local bourgeoisie, and especially the industrialists, as a means of defending their interests and redressing the injustices they suffered in benefiting from ISI strategy, and the related state benefits and support. But for the local business associations to be fully operationalised, and for the local bourgeoisie activism to turn into local entrepreneurialism, they had to wait for the transition to another accumulation regime: an open, export oriented and free-market based economic strategy. This transition, from the 1980s onwards, brought in an altered political opportunity structure for the representation of Gaziantep's local bourgeoisie. This shift was associated with changes in interest definition for the local bourgeoisies due to the increasing range of opportunities and risks to the local accumulation process. Those factors have pushed them to search for new forms and sites of representation, and thus enter the scalar strategies of representation.

As the following chapters will show, in the case of Gaziantep this mobilisation of local business associations, and the claims they raised before the state and other interlocutors, gained legitemacy and credibility through construction of a local corporate regime aiming to promote a particular local accumulation strategy. In this regard, an important novelty of the local bourgeoisie activism is that, beside (local) business associations, it also has to invent its own locality as a political actor. It has to 
invest in its own institutional policy-making capacity, and then has to use this capacity to organise the actions of other key local actors according to its priorities. We will discuss the formation of Gaziantep's new accumulation strategy in Chapter 3. In Chapter 4 we shall discuss the implications of this strategy shift and the political developments at the national scale for Gaziantep's local politics, including the formation of the local corporate regime and the changing axes of interest definition. Chapters 5 and 6 concentrate on the scalar strategies of representation developed and pursued by the local corporate regime of Gaziantep led by the local chambers of industry and commerce. 


\section{CHAPTER - III}

\section{"The case of Gaziantep: Roots of Gaziantep's local entrepreneurialism"}

This chapter has two main objectives. First, it aims to explain the theoretical significance of Gaziantep as a case study. Second, it aims to explain the emergence of Gaziantep's entrepeneurialism in relation to the post-1980 national accumulation strategy change and the associated re-scaling of the state. To meet the first objective, the chapter gives a brief account of the recent economic success of Gaziantep. This has been used by many policy-makers and scholars to make the case that a neoliberal economic regime can produce successful results, and that cities and regions can act as substitutes for the national state in economic policy-making. To deal with the second objective, the chapter proceeds to question these claims in the case of Gaziantep, and introduces the thesis that success comes through the political mobilisation of the local bourgeoisie, and that this mobilisation is influenced by and responds to the re-scaling process of the state.

The thesis is developed in the following sections. First, the question of how the introduction of a liberal oriented economic regime, and the associated changes in the functioning and logic of the state actions, stimulated the industrialisation process in Gaziantep is discussed. In particular, the political implications of these changes for Gaziantep's local bourgeoisie are analysed. The following section takes a closer look at 
the re-scaling of the state, involving a series of changes in the forms of intervention, internal organisation and representation. These moulded the agency of Gaziantep's local bourgeoisie, and especially its industrial fraction, by turning the local business associations into strategic venues and agents of political representation for them. The section also explains why and how the scalar strategies of representation were adopted by Gaziantep's local business associations. Finally, the chapter suggests that we have to investigate the dynamics of Gaziantep's local politics so as to understand how and through what mechanisms this local bourgeoisie activism has been transformed into local entrepreneurialism.

\section{Gaziantep: An examplary achievement of the new economic model?}

\section{Why Gaziantep?}

As mentioned in the introduction, a number of cities in Anatolia, including Gaziantep, emerged as dynamic nodes of industrialisation and economic development during the late 1980s and 1990s, following the accumulation strategy shift that came in 1980 (Chart 3.1). ${ }^{81}$

\footnotetext{
${ }^{81}$ Source: Adapted from "Structure of provinces of Denizli and Gaziantep's manufacturing industry", DPT: 2002: 4 and DIE - website, for figures of net domestic product by provinces, 1997 onwards (note that DIE numbers and DPT numbers are slightly different: for example, in DIE sources, the share of Gaziantep in total national domestic product is $1.5 \%$, not 1.4). The chart was produced by the author.
} 


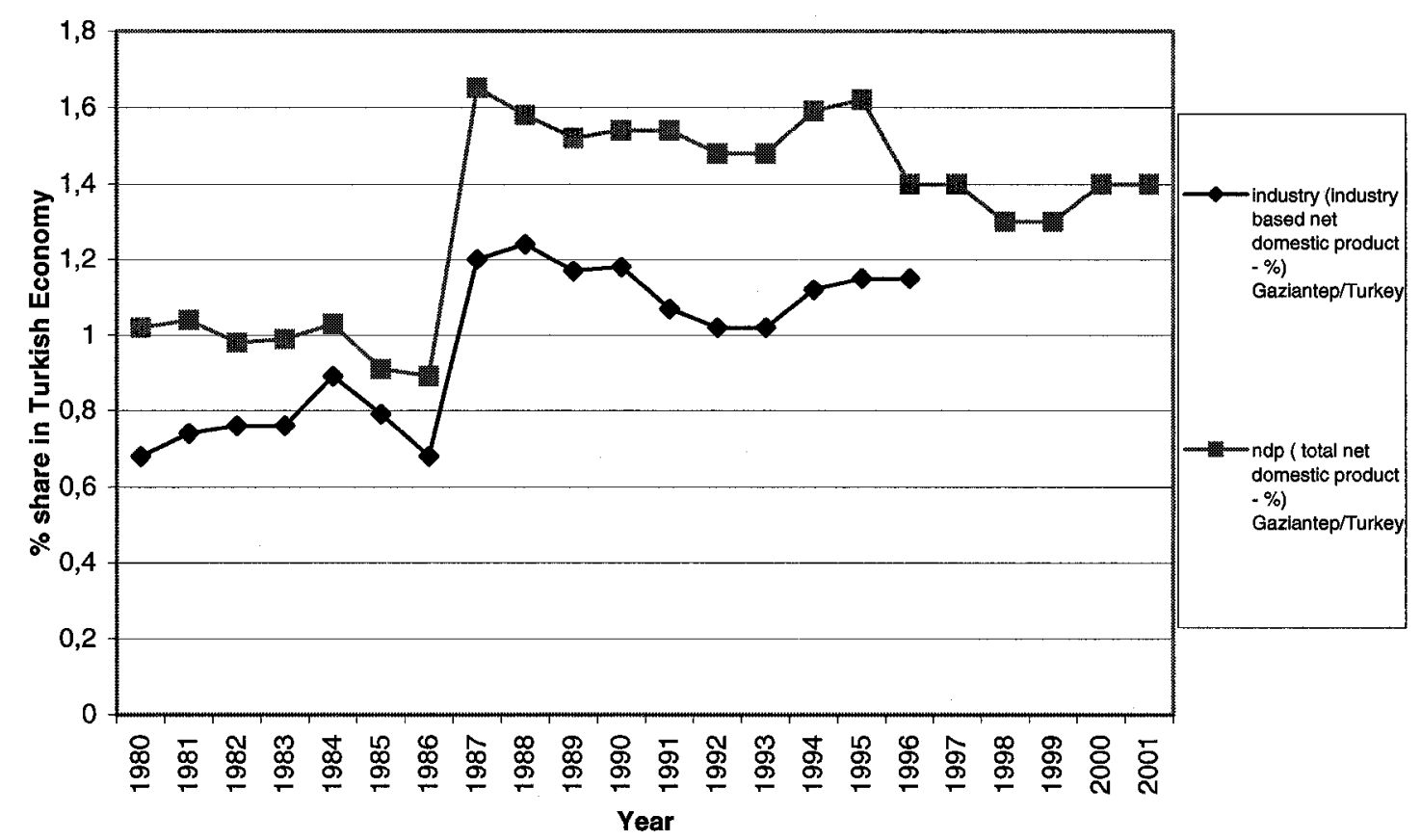

Thus, Gaziantep's weight in the Turkish economy has increased both in terms of industrial net domestic product (NDP) and total net domestic product, especially since the late 1980s. Gaziantep's share of the total net domestic product has been influenced by the development of its industrial sector, as Gaziantep's share of total NDP runs parallel to that of industry. Even when the total NDP decreased after 1995, the industrial sector stayed at the same level in terms of industrial NDP. Moreover, Gaziantep's share in the gross domestic product of its own region (Southeastern Anatolia) rose to around $50 \%$, in 1988. 
The economies of Anatolian Tigers were characterised by an increasing number of small and medium sized industrial enterprises involved in industrial production, a 'spirit of entrepreneurship', increased export production and intensified links with international markets. This development came after the introduction of a new accumulation strategy based on the principles of open, export-oriented and liberal economy, and the Tigers emerged in the regions of the country that used to be underdeveloped and/or stagnant in economic terms. Thus, they were increasingly seen as the proof of success of the new economic order, and perceived as examples that confirm the insights of the mainstream approaches to the recent rise of cities and regions.

As Chapter 2 indicated, however, the roots of the current industrialisation process of these Anatolian cities and the associated local bourgeoisie activism can be traced back to the accumulation strategy preferences, state interventions and the intrabourgeoisie struggles of the pre-1980 period. In this chapter, I argue that the accumulation strategy shift and the associated state re-scaling process of the post-1980 period, which included changes in the state forms of intervention, internal organisation and representation, paved the way for the transformation of the pre-1980 local bourgeoisie activism into local entrepreneurialism, and shaped the agenda of local accumulation strategies, by effectively stretching, or re-scaling the focus of local accumulation strategies. In the preceding chapters I argued that the emergence of local entrepreneurialism in the form of a local corporate regime, and the formulation and implementation of a multi-scalar local accumulation strategy can become possible only 
through the political mobilisation of the local bourgeoisie. In this regard, Gaziantep stands out as a rich example through which we are able to analyse these dynamics.

In fact, the politically motivated local claims regarding the role of Gaziantep as a national "pioneer" and "model" in this new economic development model, which has been aggressively promoted by Gaziantep's local corporate regime and is widely accepted by the national politicians and business people from other cities, ${ }^{82}$ further encourage us to take a closer look at the case of Gaziantep. For example, an excommissioner of the EU to Turkey, Michael Leigh, declared that integration with the EU would not work anywhere if it does not in Gaziantep. Similarly, in 1998, Süleyman Demirel, the then-president of Turkey, commented that "if you want to understand what is going on in Turkey, go and see Gaziantep" (Gözlem 1998). Here, Gaziantep rises up as a 'smaller scale model of the country' or as the 'scale of the country' (Nejat Koçer, editorial, Değişim March -April 2003, 18) ${ }^{83}$, a model that the nation should follow. In this regard, the entrepreneurs of Gaziantep bear a national responsibility. See, for

\footnotetext{
${ }^{82}$ Because of this perception, special attention is paid by the national politicians to the city. For example, within two months of coming to power, the the current AKP (Adalet ve Kalkınma Partisi - Justice and Development Party) government sent three ministers to visit Gaziantep - Ali Coşkun, the Minister of Industry and Trade; Kürşat Tüzmen, the Minister of State responsible for Foreign Trade; Sami Güçlü, the Minister of Agriculture (Değişim May-June 2003. Also see Gaziantep'te Sabah 30 May 2002; 13 June 2002). And given this attention, Gaziantep naturally became the place for many pilot projects. The most recent instance of these projects is the restructuring of the KOSGEB (Küçük ve Orta Ölçekli Sanayi Geliştirme ve Destekleme İdaresi Başkanlığ - Small and Medium Industry Development Organization), whose first national pilot project was the small industrial estate built in Gaziantep, in 1973. Erkan Gürkan, its new director, states that the KOSGEB was born in Gaziantep, and its second-birth will happen in Gaziantep, too (Değissim May-June 2003, 34-35). Similarly, the representative of the largest holding in Turkey (the KOÇ group), Ali Koç, declares that they will start a new information infrastructure service targeting the SMEs in Turkey (KOBILINE), in the capital of Anatolian Tigers, Gaziantep (Genç Çizgi 4 $(8), 25)$.
}

${ }^{83}$ Also, INTERVIEW WITH KÜRŞAT GÖNCÜ 
example, the following comment of the current president of the TOBB on Anatolian

Tigers:

The pioneering role of these cities ... places a big responsibility on the shoulders of their entrepreneurs. Let's not forget that the eyes of Turkey, and even the world, are on these provinces. People got used to always remember these provinces with [their economic] success. A smallest hesitation, a pause [in their economic development], no matter what the reason may be, will have a great echo and surprise [everyone]. For this reason, the entrepreneurs of [these] provinces have to sustain their dynami[sm] (Interview with Rifat Hisarcıklığlu, in Değişim July-August 2001, 15). ${ }^{84}$

To summarise, the success of Gaziantep is the success of the country; failure of Gaziantep is the failure of the country. Or, as the motto of the Gaziantep Chamber of Industry reads: it is "Turkey in the World, Gaziantep in Turkey".

\section{To what extent can the mainstream accounts explain the success of Gaziantep?}

Given this emphasis on Gaziantep as a national model to be followed, and the attention attached to its entrepreneurialism by policy-makers, it becomes crucial to discuss to what extent the potential explanations raised by the mainstream accounts of the rise of cities and regions outlined in the theory chapter make sense in the case of Gaziantep. In fact, when asked what makes Gaziantep a model city, many entrepreneurs and local opinion leaders made statements which included phrases such as 'entrepreneurialism', 'competitive, hard-working people', 'successful without direct help of the state', 'standing on their own feet', and 'cooperation and solidarity'. Of course, when we talk

\footnotetext{
84 Translated from Turkish by the author.
} 
about a model, we should ask the purpose of the model and who(m) it is for. For its proponents, the answer would be formulated as 'a model of how a city should act and work so that it will develop in the era of economic globalisation and neoliberalism', and that it is 'a model for both other cities in Turkey and in the world.' As noted, the mainstream accounts provide us with an explanation regarding the main features of this entrepreneurial city/region by alluding to the new and innovative patterns of industrial production, and/or local particularities captured by the terms such as social capital, etc. Yet, to what extent can these factors help us to understand the experience of Gaziantep? According to Akif Ekici ${ }^{85}$, who claims to have coined the term "model city" for Gaziantep, what makes Gaziantep a model city is the priority given to production, and the industrialists' will to produce even in the midst of national and/or global economic and political crises. Another important factor is the competitive atmosphere of the city. Yet, Ekici also observes that there is still a need for the "logic of industry" to be established and settled in Gaziantep. He mentions three elements in that regard: institutionalisation; adoption and use of technology; and striking a balance in the relations between the employers and workers. ${ }^{86}$ In other words, in Gaziantep, the emergence of a unique industrial production pattern similar to those of Emilio-Romagna or Baden-Württenberg will take time. Thus, the unique face of Gaziantep's experience does not stem from the way the industrial production process is organised there.

\footnotetext{
${ }^{85}$ The ex-president of Gaziantep OSB (organised industrial district) before the election of the MÜSİADoriented candidate (between 1999 - 2003).

${ }^{86}$ INTERVIEW WITH AKIF EKICI.
} 
Could it be trust, or 'social capital' given the history of the city? The nature of the trust one can observe in Gaziantep is 'thin trust', to borrow the term introduced by Putnam (2000), where the relations are based on the mutuality principle of "do unto others", which in fact works as an important source of financing the enterprises, especially given the unreliable attitudes of the banking sector. According to Mustafa Geylani $^{87}$ the solidarity which exists in Gaziantep "is a solidarity which competition brings, caused by the [fact] that everyone is in competition. Gaziantep is not a city [which] thinks, acts collectively... Maybe the secret of success is there". ${ }^{88}$ As an outsider, Soren Hjorth, the ex-EU coordinator of the Business Centre Project hosted by the GTO, observed that the relations between the entrepreneurs were "love and hate relations" (as in the case of the Gaziantep flour industries). He maintained that it is really difficult to bring them together for projects. Similarly, Eyüboğlu (2000) argues that, the competitive structure of the economy and the cut-throat cost/price competition in Gaziantep does not leave much room for initiatives of economic cooperation. Competition, she argues, sustains the status quo characterised by small family firms, and a low level of trust and solidarity between them $(2000,54$; also see Müftüoğlu 1992).

Then what is there to be transferred as a policy lesson from Gaziantep, the pioneer city, to other localities? The answer, this study argues, lies in the political

\footnotetext{
${ }^{87}$ The ex-president of the Gaziantep Chamber of Commerce (and Industry), and the ex-president of the Assembly of Gaziantep Chamber of Commerce.

${ }^{88}$ INTERVIEW WITH MUSTAFA GEYLANI. Another interviewee, Muharrem Balat also made a similar point.
} 
activism of the representatives of Gaziantep's bourgeoisie, the level of political cooperation displayed by forming a corporate regime, and the representation strategies they pursue to implement a local accumulation strategy. Özcan, who conducted a comparative case study on the industrialising, 'medium-sized' cities of Gaziantep, Denizli and Kayseri, lends support to this argument by observing that "Gaziantep appears to have one of the few examples of a local consensus platform among different groups as well as between its municipality and governorate for economic development projects" $(2000,228) .{ }^{89}$ In other words, if there is a model, it is a political one, rather than an economic or social one. The emergence of local bourgeoisie activism and local entrepreneurialism have to be understood in relation to the accumulation strategies (and strategy changes) and the associated state re-scaling process. In the following section, we will take a closer look at how this recent accumulation strategy shift, and in particular the associated changes in the state forms of intervention, shaped the path of the local bourgeoisie activism by increasing the influence of the industrialists in Gaziantep's economy.

The national accumulation strategy change, re-scaled forms of state intervention, and the roots of the current local bourgeoisie activism in Gaziantep

As noted in Chapter 2, the Anatolian cities, including Gaziantep, had housed small industrial enterprises that could have initiated a widespread industrialisation during the

${ }^{89}$ Yet, her study does not elaborate on the dynamics of the concensus building process. 
early Republican period, if the small artisanal enterprises (and households) had been incorporated into a national industrialisation strategy. ${ }^{90}$ Yet, this did not happen. In the case of Gaziantep, until the late 1970s the city's economy did not perform as well as it might have. Tables 2.1 and 2.2 (in Chapter 2) indicate that, if anything, it just survived. Indeed, Table 2.1 shows that, in terms of the number of industrial enterprises registered by the state, Gaziantep ranked $7^{\text {th }}$ amongst the country's 'provinces' in 1927 . Table 2.2 shows that, at least as of 1950 , Gaziantep did not fare that well in terms of the number of the enterprises employing more than 10 workers, with its ranking of the $12^{\text {th }} .91$

Roots of the current round of industrialisation in Gaziantep can be traced back to the early 1970s. Özsağır argues that inclusion of the province of Gaziantep into the K.Ö.Y regime (Kalkınmada Öncelikli Yöreler programı - the "Areas Privileged in Development" program) ${ }^{92}$ in 1968, and the establishment of KÜSGEM (Small Industry

\footnotetext{
${ }^{90}$ Gaziantep's textile sector was very competitive during late 1890 s and early 1900 s, and it started to challenge Aleppo not simply in the regional markets of the Empire, but also in international markets. Okçuoğlu (1999) also notes that capitalist production had already diffused into Anatolia, albeit in rather primitive forms, especially in the cities where the sectors like textile or carpet making were dominant. In such cities, including Gaziantep, merchants organised this process, subcontracting different parts of the production to households. The merchants provided the households with the necessary raw materials, and marketed the finished goods, thus controlling the links between the households. This led to the eventual subordination and proletarianisation of these artisans. These production networks were not transformed into manufacturing arrangements in workshops, which would constitute the roots of higher forms of industrial production with the introduction of machinery (Okçuoğlu 1999, 271, 288-292).
}

${ }^{91}$ Between 1950 and 1963, this number increased four times. Yet, as this is also true for the country average Gaziantep did not experience a big break-through during this period, and this increase was rather based upon the growth of existing enterprises.

${ }^{92}$ In this program, a list of underdeveloped areas was determined by the state planning organisation, the DPT. The KÖY provinces (and districts) were subject to lower taxes or tax-exemptions in investments, lower labour-insurance premiums, and lower energy pricing. The list was re-determined on a two year (sometimes yearly) basis. This provided the KÖY provinces with important privileges in taxation, energy prices, etc (see Doğruel and Doğruel 2003,300). This review process was influenced by party-political considerations, not necessarily by "technical" considerations. 
Development Centre) in $1970^{93}$ as part of a UN related development project ${ }^{94}$ initiated the industrialisation process in Gaziantep (1999, 65; also see Eraydın 2002, 153-157). This confirms Brenner's insight regarding the spatiality of the Keynesian state interventions, which targeted regional equalisation. Between 1968 and 1973, and between 1978 and 1980, the province of Gaziantep benefited from the KÖY Program (www.dpt.gov.tr/bgyu/KÖY68-99.html\#KOY68-73). The number of industrial enterprises began to increase in the 1970 s especially with the positive impact of the KÖY program (Table 3.1).

Table 3.1: Manufacturing workplaces established in Gaziantep since 1960s (firms of all sizes)

\begin{tabular}{|l|l|l|l|l|l|}
\hline $\begin{array}{l}\text { Year } \\
\text { established }\end{array}$ & $\begin{array}{l}\text { Number } \\
\text { of } \\
\text { workplaces }\end{array}$ & $\begin{array}{l}\text { \% of } \\
\text { workplaces }\end{array}$ & $\begin{array}{l}\text { Employment } \\
\text { created }\end{array}$ & $\begin{array}{l}\text { \% in total } \\
\text { employment }\end{array}$ & $\begin{array}{l}\text { Average size } \\
\text { (employment } \\
\text { created/number of } \\
\text { workplaces) }\end{array}$ \\
\hline-1960 & 96 & 1.40 & 595 & 1.29 & 6.20 \\
\hline $1961-1970$ & 176 & 2.57 & 1332 & 2.89 & 7.57 \\
\hline $1971-1980$ & 556 & 8.11 & 4719 & 10.25 & 8.49 \\
\hline $1981-1992$ & 2775 & 40.48 & 23264 & 50.53 & 8.38 \\
\hline $1993-1996$ & 3253 & 47.45 & 16132 & 35.04 & 4.96 \\
\hline Total & 6856 & 100.00 & 46042 & 100.00 & 6.72 \\
\hline
\end{tabular}

Source: Özsağır $(1999,63)^{95}$

\footnotetext{
${ }^{93}$ KÜSGEM became operational in 1973.

${ }^{94}$ as a collaboration between the United National Industrial development organisation and the ministry of industry and commerce.

${ }^{95}$ I have calculated and added the values in the last column.
} 
Yet, for this industrialisation process to gain full momentum, and for Gaziantep's local industrialists to dominate the local economic scene, they had to wait for the post-1980 capital accumulation strategy shift. Despite the emergence of a local bourgeoisie activism in Gaziantep in the 1970s, the local industrialists were not strong enough to institutionalise their activism. Öncü argues that, as of 1980, among the chambers of industry in Turkey "[n]otably absent are the Bursa and Gaziantep chambers, which have been in the process of organization since the early 1970s but have yet to be established. The difficulties encountered in the organization of these two chambers, in part, stem from the ongoing struggle between commercial and industrial interests" $(1980,460)$. Establishment of a separate chamber of industry became possible only in 1989, which indicates that, by then the local intra-bourgeoisie struggles had been settled in favour of the local industrial bourgeoisie as "industrialisation" became the main economic activity informing the priorities of the local accumulation strategy. In fact, as we shall see in chapter 4 , the establishment of the Gaziantep Chamber of Industry marked the birth of the local corporate regime in Gaziantep as the politicoinstitutional form of this local bourgeoisie activism. In what ways then did the national accumulation strategy shift, and the associated state re-scaling process, promote industrialisation in Gaziantep, and lead to the emergence of industrialists as the dominant fraction of the local bourgeoise?

First, the national accumulation strategy shift changed the priorities of the local bourgeoisie by altering the sources of profit-making. The local commercial bourgeoisie were induced to transfer sources to an already budding industrial sector, thereby giving 
the first momentum to the industrialisation of Gaziantep. This was especially true for the 1980s. Second, the state interventions that included direct benefits, incentives and credits given to the individual entrepreneurs helped them to expand the territorial reach of a local accumulation strategy that relied on industrial production. These state interventions proved effective especially from the 1990s onwards. Now, let's take a closer at how these dynamics unfolded (Table 3.2).

Table 3.2: Gaziantep's industrialisation process during the post- 1980 period: The changing accumulation strategy

\begin{tabular}{|c|c|c|c|c|}
\hline Phase & $\begin{array}{l}\text { Accumulation } \\
\text { strategy and } \\
\text { the dominant } \\
\text { fraction of } \\
\text { bourgeoisie }\end{array}$ & $\begin{array}{l}\text { Financial source of } \\
\text { industrialisation }\end{array}$ & $\begin{array}{l}\text { Dominant } \\
\text { form of } \\
\text { enterprise }\end{array}$ & Spatial loci of accumulation \\
\hline $\begin{array}{c} \\
1980- \\
1990\end{array}$ & $\begin{array}{l}\text { Led by the } \\
\text { commercial } \\
\text { bourgeoisie } \\
\text { Unplanned } \\
\text { (As a reaction to } \\
\text { the national } \\
\text { economic policy } \\
\text { change) }\end{array}$ & $\begin{array}{l}\text { Locally accumulated } \\
\text { commercial capital } \\
\text { Informal, local ties are } \\
\text { central }\end{array}$ & $\begin{array}{l}\text { Small and } \\
\text { medium- } \\
\text { sized } \\
\text { enterprises }\end{array}$ & $\begin{array}{l}\text { Regional markets (national markets and } \\
\text { international markets are secondary - } \\
\text { border trade) }\end{array}$ \\
\hline $\begin{array}{c}\text { II } \\
1990- \\
2000 \mathrm{~s}\end{array}$ & $\begin{array}{l}\text { Led by the } \\
\text { industrial } \\
\text { bourgeoisie } \\
\text { Institutionalised, } \\
\text { consciously } \\
\text { formulated } \\
\text { (Birth of the } \\
\text { GSO) }\end{array}$ & $\begin{array}{l}\text { Capital accumulated } \\
\text { during the first phase }+ \\
\text { private bank credits } \\
\text { (failed) + the state } \\
\text { incentives and credits } \\
\text { The state becomes the } \\
\text { reliable source of } \\
\text { financing the second } \\
\text { phase, especially for the } \\
\text { large enterprises }\end{array}$ & $\begin{array}{l}\text { Large scale } \\
\text { enterprises }\end{array}$ & $\begin{array}{l}\text { Multi-scalar } \\
\text { Regional + National (establisment of } \\
\text { links with other Anatolian tigers such as } \\
\text { Denizli, and with İstanbul in certain } \\
\text { sectors) + International (focus shifted } \\
\text { often, due to the international and } \\
\text { domestic crises, now finally towards } \\
\text { fixed supra-national markets such as the } \\
\text { EU - sub-contracting is not the main } \\
\text { form of articulation, unlike in Denizli) }\end{array}$ \\
\hline
\end{tabular}


The spontaneous response of individual entrepreneurs to the national accumulation strategy change provided the initial impetus for Gaziantep's industrialisation, and commercial capital started to be transferred to the industrial sector in the 1980s, sparking a locally financed industrialisation process (Milli Prodüktivite Merkezi-Gaziantep 1997). In fact, in the broader economic context of the 1980s, the returns to industrial investment would not be as sizeable as the returns to other sectors of the economy. Why, then, did the entrepreneurs bother to deal with the industrial sector? This had to do with the size of commercial capital invested in industry. The scale of capital initially invested in industry was not large enough to capture the benefits of a risky-rent economy, were it to be transferred to the financial sector or to international trade. ${ }^{96}$ In addition, as a border province, Gaziantep had benefited from (illegal) border-trade before 1980. The transition to an open-economy, and disappearance of trade barriers reduced the rents that the local merchants could capture through commerce. This forced the local merchants to look for new fields of profitmaking. The presence of an already budding industrial sector based on small and medium enterprises and the availability of skilled cheap labour encouraged a spontaneous shift of capital from commerce to industry.

At this point, however, we should not rush to conclude that the introduction of an export oriented, open-economy strategy automatically turned Gaziantep into an effective competitor in the national market, or articulated Gaziantep's industry with the

\footnotetext{
96 As we shall later see later, international trade was organised by, and legally restricted to, big companies.
} 
global economy. Unlike some other industrialised/industrialising cities in Anatolia, the industrialists of Gaziantep did not follow the easier path of establishing subcontracting relations with the large scale industrial enterprises controlled by Istanbul (as in the case of Bursa), or with international companies (like in Denizli) (Eraydın 2002, 169), that could let them quickly integrate into the national and global economy. Economic development in the region was to rely on the performance of local entrepreneurs as it was very difficult to attract investers, and non-local capital to the region (Mutlu 1993, 16; Tuncer 1990, 17). ${ }^{97}$ Eraydın (2002) observes that Gaziantep long remained a regional production centre that served the domestic market and that only recently has its economy begun to be transformed into a production centre working for international markets (see Table 3.3). In other words, only now is the integration of Gaziantep's economy and global economic processes becoming more direct and visible.

Table 3.3: The export structure of Gaziantep and Denizli as of the early 2000s

\begin{tabular}{|l|l|l|}
\hline & Gaziantep & Denizli \\
\hline Share of exports (\%) (foreign demand) & 14.7 & 37.2 \\
\hline Domestic demand - intra-regional & 49.7 & 29.8 \\
\hline Domestic demand - extra-regional (national) & 35.6 & 33 \\
\hline
\end{tabular}

Source: Adapted from "Structure of provinces of Denizli and Gaziantep's manufacturing industry" (DPT 2002, 59).

\footnotetext{
${ }^{97}$ INTERVIEW WITH AYNUR ATAY.
} 
In this process, the industrialists of Gaziantep had to forge ahead by adopting a carefully drafted strategy to re-scale the scope of their local accumulation. This involved an active search for new interlocutors who could help them strengthen the position of Gaziantep in the national and international hierarchy of localities. At the same time, they also pursued an aggressive engagement strategy with the critical nodes of decision making within the institutional boundaries of that national state. There were two types of such policy instruments and programs that had a capacity to influence the dynamics of local economic development in Turkey: a) Territorially-framed policy instruments which provided a package of benefits specific to the region or locality; and b) The measures and incentives that targeted individual entrepreneurs and/or sectors. An extensive list of these instruments is provided in a report prepared by the Turkish Industrial Development Bank (Türkiye Sanayi Kalkınma Bankas1 - TSKB) in 1991, which can be arranged according to the above distinction as follows:

\section{Territorially framed policy instruments (spatially sensitive)}

a) National 5-Year Development Plans, emphasising the significance of promoting underdeveloped regions of Turkey (the first one prepared in 1963, by the DPT - the state planning organisation).

b) The policy of "Areas Privileged in Development” (Kalkınmada Öncelikli Yöreler KÖY): A list of underdeveloped areas determined by the State Planning Organisation (see our earlier discussions on the KÖY program in this chapter). 
c) Regional plans prepared for specific regions (not for every region - prepared when needed).

d) Rural development projects (indeed few have been developed).

e) Direct Public investments: infrastructure investments; public economic enterprises geared towards industrial production.

f) Organised Industrial Districts (OIDs) (could be instituted by the state, upon request of the locals).

Non-territorial (spatially insensitive - targeting individual entrepreneurs or sectors)

g) Universally provided state and international credits provided via different (national or international) funds.

h) Foreign and domestic credits provided by public and private banks.

i) Other, non-spatial, especially industrial export policies followed by the government (TSKB 1991).

In fact, despite the recognition of regional imbalances in economic development, the 5-year development plans of the pre-1980 period had failed to develop a comprehensive and integrated approach to local/regional development. In terms of discourse, state action was framed as making public investments in a geographically balanced way (Günçe 1981, 124; Tekeli 1980, 1981). Ironically, despite the fact that the neoliberal policies of the post-1980 era paralysed the 5-year development plans, ignored the question of uneven development, and completely ruled out the ideological emphasis 
of spatially planned accumulation, territorially sensitive policy instruments gained significance as a form of intervention. Özal's Motherland Party (ANAP) government initiated the largest and most integrated regional development project (including Gaziantep) that Turkey has ever had. The Southeastern Anatolia ${ }^{98}$ project (Güneydoğu Anadolu Projesi - GAP) became a landmark project of the post-1980 era in Turkey. In addition, the KÖY program also gained vitality after the mid-1990s, albeit on populist grounds. Unfortunately, the territorially-framed state interventions of the post-1980 era largely bypassed Gaziantep. In particular, Gaziantep was left outside the scope of GAP and KÖY-related incentive and subsidy schemes ${ }^{99}$, which continues to provoke harsh criticism from the business associations in Gaziantep. Thus, their potential contribution to Gaziantep's industrialisation was, at best, indirect, if not obstructive. We will later

\footnotetext{
${ }^{98}$ In fact, certain provinces in Eastern Anatolia and Southeastern Anatolia (like Hakkari and Şrnak) have an average per capita annual income which is close to that of Senegal and Sudan, while the Western industrialised provinces, like Kocaeli, enjoy an average which is in the same category with Ireland (in dollar terms, 1995 values). This is also the case in terms of the socio-economic indicators like life expectancy, infant mortality, etc (Şenesen 1999; Sönmez 1999, also see Ataay 2001 - For a detailed socio-economic, as well as physical and demographic description of the GAP region refer to Bağış 1989).

This gap has been seen by the military as the root cause of the rising Kurdish nationalism in the region. Although GAP's roots as a collection of individual water-works projects can be traced back to 1938 , it was the late 1950s and early $1960 \mathrm{~s}$ when the idea of initiating a regionally integrated irrigation and energy project was seriously considered, helped by the active lobbying of the MPs from the region (Turgut 1995; www.gap.gov.tr). A series of dam and irrigation projects was under way, when ANAP turned it into a comprehensive regional development project, which assigned this responsibility to the State Planning Organization in 1986. Establishment of the GAP Administration Agency in 1989 was the second step taken (www.gap.gov.tr) with broader socio-economic aims in mind. The logic of such a comprehensive project could be related both to the political concerns of the nation state (to contain the emerging ethnic regionalism in Southeastern Anatolia); and to the economic recovery strategy of the ANAP governments relying on sectors such as construction, energy and housing. Thus, the project was seen as a means of cementing the unity of the Turkish state. What is more, as a huge infrastructure project, GAP has offered the Motherland Party and its successors in government a chance to transfer state sources to infrastructure and energy sectors.
}

${ }^{99}$ This happened despite the fact that, unlike other Southeastern provinces, it was only Gaziantep and Mardin where the private sector dominated the local economy (Kasnakoğlu 1990, 9). 
return to the reasons behind the exclusion of Gaziantep from the territorial programs, and its implications for the representation strategies of Gaziantep's local bourgeoisie.

The most important form of state intervention that contributed to Gaziantep's industrialisation, therefore, was the non-territorial state instruments (Özsabuncuoğlu et al. 1999, 44). They included universal export and investment credits, incentives and subsidies, as well as the insurance given by the state when entrepreneurs borrowed from international financial sources. As Table 3.1 and Chart $3.2^{100}$ suggest, these state programs made an important difference in the industrialisation of Gaziantep, especially from the 1990s onwards. Yet, for the industrialists of Gaziantep to benefit from these resources, they had to grow stronger in both economic and political terms, and had to directly engage with the strategic nodes of decision-making within the political apparatus of the state. Hence it is not surprising to see that the industrialists of Gaziantep began to receive these state benefits after they finally succeeded in establishing themselves as a politically motivated and institutionalised force under the umbrella of an independent local chamber of industry.

${ }^{100}$ Adapted from "Structure of the manufacturing industry of provinces of Denizli and Gaziantep", DPT: 2002: 10 


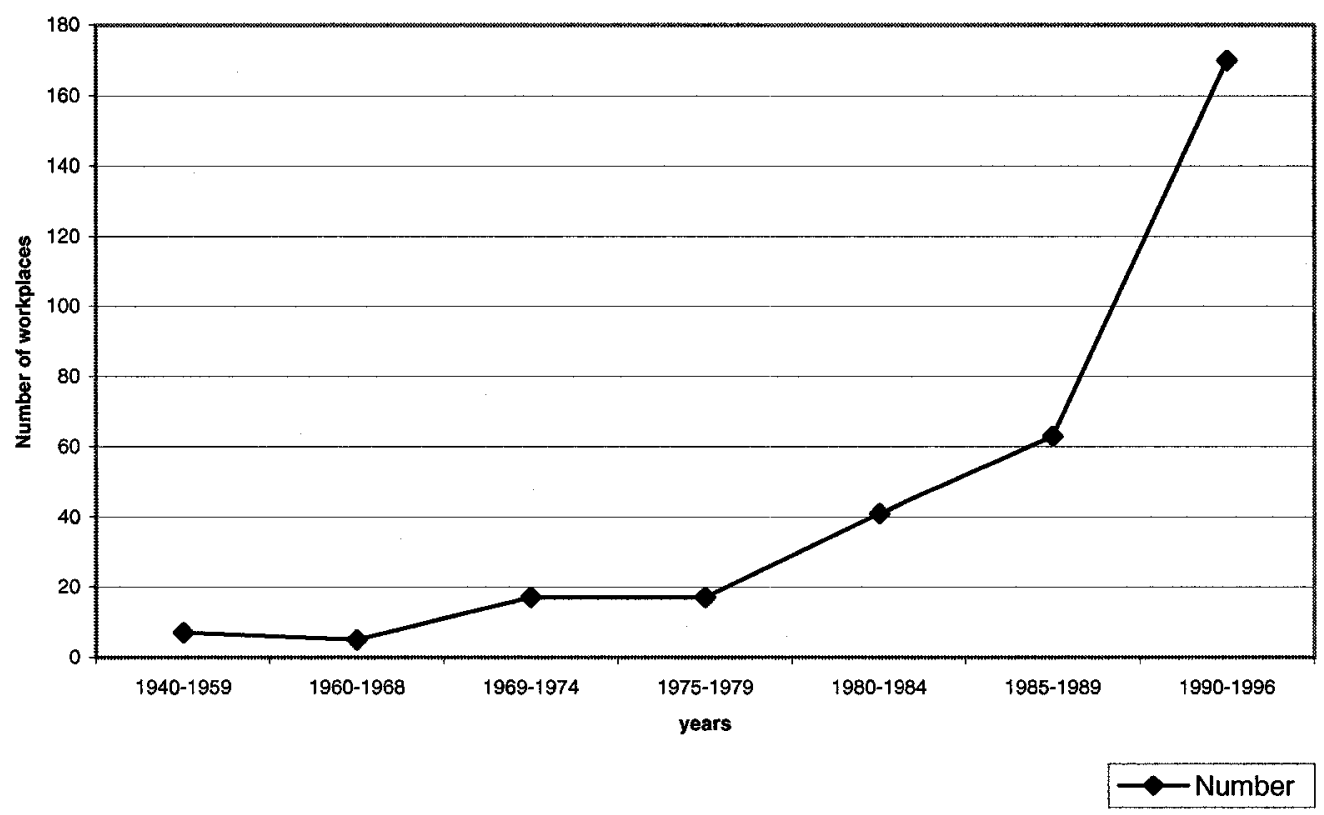

We can identify three main sorts of incentive provided by the undersecratariat of treasury and foreign trade (later split into two): 1) 'export incentives' that were introduced as part of the export-orientation of the economic policy; 2) the 'investment incentives'; and 3) KOBI ${ }^{101}$ (Small and Medium Enterprises) incentives. The export and investment incentives were introduced by Özal's Motherland Party to support the new national economic strategy. To analyse the trends in use of export and investment incentives Chart $3.3^{102}$ has been created.

\footnotetext{
${ }^{101}$ Here KOBİ as such does not stand for Esnaf, who are truly small enterprises.

${ }^{102}$ Source: Printed data received from the Undersecretariat of Foreign Commerce (the directorate of incentives implementation-the branch of monitoring).

Note: These values refer to the number of export and investment incentive certificates received by the firms in Gaziantep. For export incentives, 2002 refers only to the mid-year value.
} 
Chart 3.3. Number of export incentive certificates and investment incentive certificates given to the firms in Gaziantep

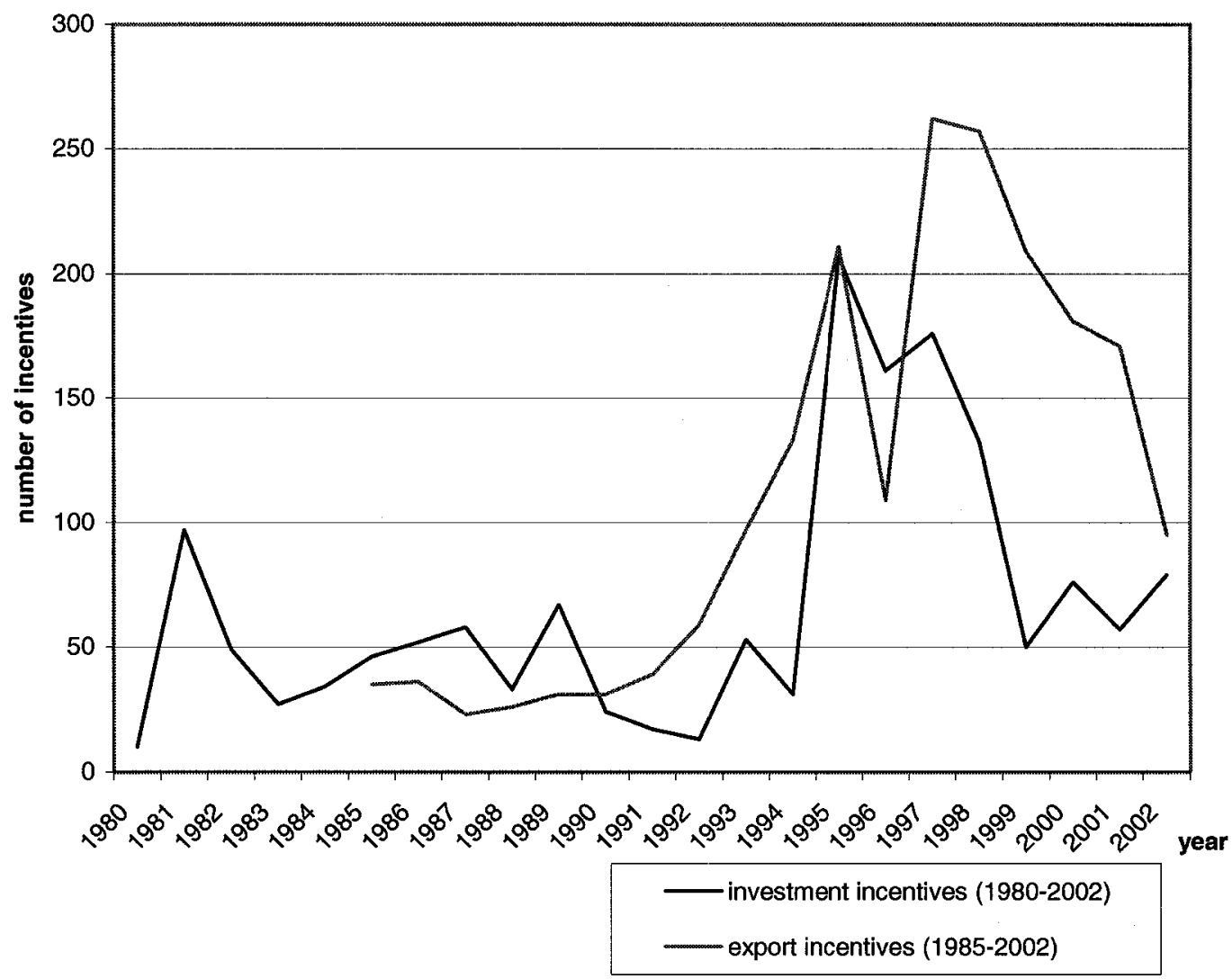

As Chart 3.3 shows, it was only in the early 1990s (especially from 1992 onwards) that the firms in Gaziantep started to apply for export incentives. There is a striking parallel between this trend and the growth trend of the large scale enterprises in Gaziantep. It could be argued that large scale enterprises in Gaziantep used these incentives to jump the league and to re-scale their field of action ${ }^{103}$, and as Table 3.4

\footnotetext{
${ }^{103}$ It is also worth noting that the export credits have been used mainly by the firms in textile and food, the most important two sectors of Gaziantep, along with metal works and machinery, and chemicals. The last two sectors, it seems, have been less interested in export incentives. It could be argued that, textile and food sectors have taken more decisive steps in articulating themselves with the global economy, than metal works, machinery and chemicals.
} 
indicates, it was actually the manufacturers themselves who used these incentives, rather than the intermediary export and import firms (unlike the case in the rest of Turkey - see İlkin 1992). In other words, in this re-scaling process of Gaziantep's industry, commercial sector did not play an intermediary role. Industrialists have preferred to play it alone, and export incentives mainly contributed to the flourishing of the industrial sector in Gaziantep.

Table 3.4: Export incentives - distribution of the export incentives according to the firm's area of activity (legally defined)

\begin{tabular}{|l|c|}
\hline Firm type & Number of certificates \\
\hline Foreign trade & 1 \\
\hline Exporter & 49 \\
\hline Manufacturer & 1011 \\
\hline Exporter and Manufacturer & 674 \\
\hline Sectoral Foreign Trade & 5 \\
\hline
\end{tabular}

Source: Printed data received from the Undersecretariat of Foreign Commerce.

Note: This table includes the period from 1990 onwards. There is no available data for the pre-1990 period.

Export incentives - sectoral distribution of the export incentives given to the firms from Gaziantep (19852002 , number of incentives)

\begin{tabular}{|l|l|}
\hline Sector & Number of incentive certificates given \\
\hline Weawing and textile & 1032 \\
\hline Food and Alcoholic drinks & 629 \\
\hline Plastic & 68 \\
\hline Chemicals & 85 \\
\hline Leather & 20 \\
\hline Others & 171 \\
\hline Total & 2005 \\
\hline
\end{tabular}

Source: Printed data received from the Undersecretariat of Foreign Commerce

Note: the original data sheet involves numerous sectors, but those using less than 10 (inclusive) are included into the others category. 
If we return to Chart 3.3, we see that the rise in the use of export incentives during the 1990s has been associated with a sharp increase in the use of investment incentives. During this phase, state incentives constituted an important source of financial support for the local industry, which had come to the limits of its reliance on local sources. The financial sector was not of much help, either. In fact, the period from the 1990 s and to the early 2000 s was characterised by an unstable financial atmosphere that gave rise to major troubles for the industrialists of Gaziantep. A good example of this was confrontation between the banks and industrialists in Gaziantep, following the national financial crisis of 2001 . To finance their growth - in the context of articulating themselves with the national and global economy - Gaziantep's industrialists had to borrow from private banks, as local sources had come to their limits to support the second phase of industrialisation. Yet, they paid a high price for this. Following the national financial crisis of 2001, the banks forced those who got credits to pay early, and confiscated the machinery and the workplaces of the enterprises who failed to repay their loans in time. ${ }^{104}$ In the middle of all this, the investment incentives provided by the state constituted a reliable financial source and provided a considerable

\footnotetext{
${ }^{104}$ The entrepreneurs themselves, Gaziantep Chamber of Commerce (GTO), and Gaziantep Chamber of Industry (GSO) and other institutional representatives, as well as the local media - Gaziantep'te Sabah in particular - fiercely resisted this pressure. The social tension heightened to such an extent that a lawyer representing a bank was killed. The tension receded after the banks' decision to stop the legal procedure. Local branches of the banks were in the forefront of the dispute, and the decision to stop the procedure was taken by their headquarters, in recognition of the urgency of the situation and tension in the city (INTERVIEW WITH AYKUT TUZCU).
} 
contribution towards the financing of the growth of large scale enterprises ${ }^{105}$ while rescaling Gaziantep's local accumulation strategy.

This also true for the KOBİ incentives that were introduced as a result of the post-1980 goverments' efforts to support small and medium enterprises, which were believed to contribute to the export-based economic growth strategy. As noted earlier, Esnaf enterprises are not understood to be KOBİs. KOBİs, in our case, refer to rather larger enterprises. The measures of the KOBİ program involved creation of a national agency for SMEs, namely the KOSGEB, which also has a branch in Gaziantep. The KOSGEB's main responsibility is to provide SMEs with necessary technological, financial and organisational support. The financial dimension of this support was organised by the undersecretariat of treasure and foreign trade. There are two lessons from the story of KOBİ incentives in Gaziantep: 1) that entrepreneurs in Gaziantep fared much better than the entrepreneurs of other industrialised localities in receiving the state benefits (Table 3.5 and Chart $3.4^{106}$ ); and 2) that larger scale enterprises were at the forefront in receiving such benefits (Table 3.6).

\footnotetext{
105 And it is highly likely that the same firms used both type of incentives, simultaneously.

106 (in Turkish Liras)

Source: adapted from

http://www.kosgeb.gov.tr/Ekler/Dosyalar/BilgiBankası/13/Tesvik\%20istatistikleri.xls

the list has been sorted according to the last column
} 
Table 3.5: Number of KOBİ incentive certificates given by the KOSGEB

\begin{tabular}{|l|r|r|r|r|r|r|r|}
\hline & $\mathbf{1 9 9 7}$ & $\mathbf{1 9 9 8}$ & $\mathbf{1 9 9}$ & $\mathbf{2 0 0 0}$ & $\mathbf{2 0 0 1}$ & $\mathbf{2 0 0 2}$ & Total \\
\hline İSTANBUL & 198 & $\mathbf{1 8 2}$ & 94 & 110 & $\mathbf{1 0}$ & $\mathbf{3 8}$ & $\mathbf{6 3 2}$ \\
\hline GAZİANTEP & $\mathbf{3 6}$ & $\mathbf{6 6}$ & $\mathbf{8 6}$ & $\mathbf{9 8}$ & $\mathbf{1 0}$ & $\mathbf{1 0}$ & $\mathbf{3 0 6}$ \\
\hline BURSA & 97 & 34 & $\mathbf{4 5}$ & $\mathbf{3 5}$ & 4 & 14 & $\mathbf{2 2 9}$ \\
\hline İZMir & 101 & 43 & 38 & 20 & 3 & 15 & 220 \\
\hline ÇORUM & 31 & 40 & 48 & 29 & 10 & 16 & 174 \\
\hline KAYSERI & 37 & 23 & 27 & 16 & 3 & 14 & 120 \\
\hline ADANA & 42 & 18 & 18 & 28 & 1 & 11 & $\mathbf{1 1 8}$ \\
\hline DENİLI & $\mathbf{1 1}$ & 5 & 4 & 4 & & 10 & 34 \\
\hline
\end{tabular}

Source: adapted from

http://www.kosgeb.gov.tr/Ekler/Dosyalar/BilgiBankas1/13/Tesvik\%20istatistikleri.xls

Note: The list has been sorted according to the last column.

The number and amount of KOBİ incentive certificates received by Gaziantepbased enterprises constantly, and sharply, rose during the late 1990s. The sudden fall that took place in 2001 has to do with the financial crisis that occurred in the same year, almost bringing the state's financial activities to a halt. Nevertheless, a comparison of Chart 3.4 and Table 3.6 indicates that while in the context of crisis fewer firms were able to receive KOBİ incentives, the average amount of incentives received by the firms in Gaziantep considerably increased the year following the crisis (2002), surpassing the averages of İstanbul and Çorum that were around the same level with that of Gaziantep during the 2000-2001 period. This suggests that larger firms in Gaziantep had recourse to the KOBI incentives meant to be provided to the "smaller" enterprises. Here, it can be argued that the nature of KOBİ incentives as "state resources distributed on 
relatively technical grounds", away from the reach of political pressure ${ }^{107}$, made them a more reliable source of state support in a context characterised by political crisis.

Chart 3.4. Total Amount of KOBI incentive given by the KOSGEB in selected, industrialised provinces

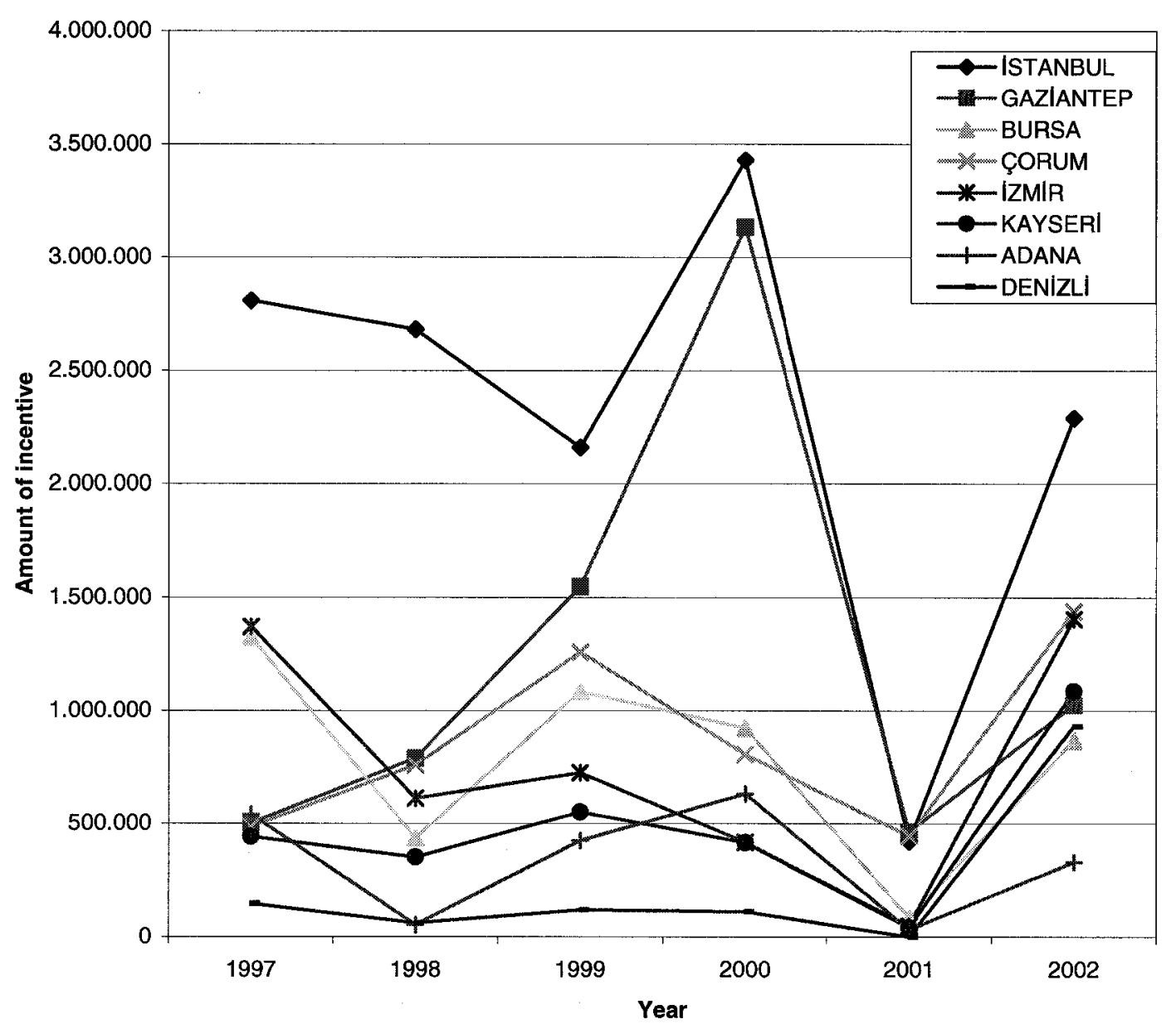

${ }^{107}$ The KOSGEB is controlled by a council/consortium whose membership is made up by numerous public, private and semi-public institutions and organisations. This organisational/management structure of the KOSGEB makes it appear as an institution where it is difficult to establish the dominance of a group, or member institution. 
The example of KOBİ incentives, along with the examples from other incentives, supports the claim that the state support schemes played a critical role in the pursuit of the local accumulation strategy of Gaziantep, and that this strategy has increasingly been shaped and led by larger scale enterprises whose owners comprise the stronger section of the industrial bourgeoisie of Gaziantep. The KOBİ example also indicates that larger enterprises of Gaziantep do not give up on the resources provided by the state, even at times of crisis. Depending on the political situation, they just change the site of engagement with the state.

Table 3.6: Amount of KOBİ incentive per certificate (million Turkish Liras) ${ }^{108}$

\begin{tabular}{|c|c|c|c|c|c|c|c|}
\hline & 1997 & 1998 & 1999 & 2000 & 2001 & 2002 & Average \\
\hline ÇORUM & $15,674.03$ & $18,953.75$ & $26,204.06$ & $27,729.31$ & $44,462.50$ & $89,908.06$ & $21,555.26$ \\
\hline GAZIANTEP & \begin{tabular}{|l|}
$13,959.67$ \\
\end{tabular} & $11,932.45$ & $18,005.23$ & 31,958.62 & $46,455.00$ & $102,498.00$ & $21,029.53$ \\
\hline ISTANBUL & $14,180.18$ & $14,731.15$ & $22,968.83$ & $31,169.09$ & $42,070.00$ & $60,260.95$ & $18,191.64$ \\
\hline BURSA & $13,639.76$ & $12,812.94$ & $24,050.00$ & $26,337,14$ & $20,750.00$ & $61,964.29$ & $16,793.66$ \\
\hline KAYSERI & $11,913.11$ & $15,305.43$ & $20,368.52$ & $25,946.88$ & $13,800.00$ & $77,507.14$ & $14,994.25$ \\
\hline IZMIR & $13,575.10$ & $14,235.40$ & $19,047.37$ & $20,815.00$ & $16,233.33$ & $93,723.07$ & $14,418.21$ \\
\hline ADANA & $12,842.86$ & $29,955.56$ & $23,550.00$ & $22,564.29$ & $32,000.00$ & $30,009.09$ & $14,245.93$ \\
\hline DENIZLII & $13,285.91$ & $12,045.00$ & $29,600.00$ & $27,625.00$ & 0 & $92,870.00$ & $12,802.06$ \\
\hline
\end{tabular}

Source: adapted from

http://www.kosgeb.gov.tr/Ekler/Dosyalar/BilgiBankas1/13/Tesvik\%20istatistikleri.xls

Note: The list has been sorted according to the last column.

108 Please note that when the GAP provinces, such as Adiyaman, Şanlıurfa, Diyarbakır and Kahramanmaraş are added to the list as the provinces of the region, they occupy the first four places in the above table. Initially, they were included when we first constructed the tables. But, having realised that they are GAP provinces, thus having an extra source of incentive priority, and that their level of industrialisation is not close to that of Gaziantep, they have been left out of the comparison. 
Despite the fact that all these benefits are provided on an individual and/or sectoral basis, the entrepeneurs of Gaziantep appear particularly active and successful in getting the state resources and benefits, when compared with many other industrialised provinces. Following the insights of our theoretical discussions we can say that the success of Gaziantep's entrepreneurs in capturing these scarce resources has to be understood as a result of "collective action", rather than as a reflection of the entrepreneurial spirit of individual entrepreneurs of Gaziantep. In a crisis-ridden political atmosphere, and within a context characterised by the concentration of decision-making powers, success could not come without some form of organised and conscious collective effort. Below, we will investigate the context that produced this "collective effort" by concentrating on the consequences of the post-1980 national accumulation strategy change, and the associated state re-scaling process for the mobilisation of Gaziantep's local bourgeoisie.

The state re-scaling, emphasised agency of local business associations, and the birth of the scalar strategies of representation

The post-1980 national accumulation strategy shift and the associated changes in the forms of intervention greatly influenced and shaped the path of industrialisation in Gaziantep and contributed to its emergence as an entrepreneurial city. This happened in two ways. First, the accumulation strategy shift and the associated re-scaling of the forms of intervention and representation contributed to the alteration of intra- 
bourgeoisie balances at the local scale, while also further emphasising the significance of local business chambers as strategic sites and vehicles of local bourgeoisie activism. Second, the strategies and sites of political representation of Gaziantep's bourgeoisie were also re-defined due to the shift in the institutional and territorial loci of distribution of state oriented benefits, along with the increasing intensity of relations with the national economy and the international economy.

To start with the first, by triggering a rapid industrialisation process, the national accumulation strategy shift contributed to the emergence of a stronger industrial bourgeoisie in Gaziantep during the 1980s, thereby sowing the seeds for local bourgeois activism around a local industrialisation strategy. Yet, a decade had to pass for this potential to bring forth an organised political mobilisation, despite the fact that the post1980 governments promoted a business-friendly political climate. The changes in the political opportunity structure during the 1980 s played an important part in this delay. ${ }^{109}$ Despite its pro-business attitude, the Motherland Party of Özal (in power from 1984 to 1991) was not pleased to see the rise of organised business representation, including the big business associations, like the TÜSİAD. The Motherland Party preferred clientelist relations over the organised institutional representation of business interests (Buğra 1994; Barkey 1990, 184; cf. Ergüder 1991, 165). In this process, the centralisation of decision-making powers in the hands of the Prime Minister enhanced his bargaining

\footnotetext{
109 The most important political gain on the part of Gaziantep's bourgeoisie during the 1980s was the political defeat of the Left, which left local industrialists without a credible rival. One of the interviewees, a labour activist and local politician (INTERVIEW WITH MECIT BOZKURT), emphasised that there had actually been a lively atmosphere of labour activism in Gaziantep before the Coup. The power of Ecevit's pre-1980 CHP in Gaziantep lends support to this statement.
} 
power, and helped him and his party to impose the rules of the game as the major interlocutor of the business interests in Turkey. In fact, the national umbrella organisations had already been de-politicised, soon after the 1980 Coup. The increasing difficulty of reaching the Prime Minister and the government via institutional channels further discredited the national umbrella representative organisations in the eyes of the bourgeoisie (cf. Buğra 1994, 349) ${ }^{110}$ especially during the 1980 s.

Ironically, the opportunity structure that emerged in the 1980s, and the dominance of clientelism as a form of representation during this period, had significant repercussions for the political mobilisation of Gaziantep's local bourgeoisie. The 1982 constitution had prohibited official representation of the TOBB and the TESK in the parliament, as well as establishment of direct contacts between such business organisations and the political parties (Yalkın 1999, 45). Consequently, in the 1980s, such umbrella organisations lost their significance as sites and channels of representation, ultimately leading to the re-scaling of the institutional channel of representation to the local level. This was especially true for the firms other than the holding companies, who had already re-scaled their site of representation to the national and international scales during the 1970 s by turning themselves into a more unified block under the TÜSİAD. ${ }^{111}$ In other words, the significance of local business

\footnotetext{
${ }^{110}$ As Ergüder indicates, "the MP [the Motherland Party] appears to have derived its support from a coalition of groups in the cities and towns who were adversely affected by the politics of 1970 s ... The MP has yet to show evidence of institutionalization in terms of party organization. It seems to be leaderdominated like the pre-1980 political parties and lately shows growing dependence on patronage to build party organization and establish itself in power" $(1991,165)$
} 
associations as the defenders of bourgeoisie interests considerably increased. ${ }^{112}$ Local chambers had to assume a more proactive role as agents of representation, which included searching for new institutional sites and interlocutors of representation, given the difficulty in finding access to the critical nodes within the state that were responsible for the new incentive and support schemes.

As our theoretical discussions indicate, at times of dissolution of a representative organisation, the "logic of membership" tends to dominate the formation process of new, or splinter, associations. This was also the case with the landscape of business associations in Turkey and in Gaziantep. The most important example of this development in Gaziantep was the creation of a specialised chamber of industry in 1989. Given the earlier political superiority of the commercial bourgeoisie over the industrial bourgeoisie, the internal politics of the TOBB had served to re-produce this superiority at the local scale until the 1980s. Using their political contacts at the national level (especially in the case of the TOBB), the commercial fraction of the local bourgeoisie had been able to prevent the establishment of independent chambers of industry. Once this intra-organisational superiority at the national level disappeared, the now powerful local industrial capital found a chance to organise into a separate chamber of industry. The 1989 split of the Gaziantep chamber of commerce and

${ }^{111}$ Especially after the late 1980 s, the TÜSIAD has grown in political influence, defining a new institutional ground for representation of big capital located in Istanbul, diminishing the institutional significance and utility of TOBB for their representation. The official consultant of TOBB presidency, Prof. Sariaslan, openly criticises this by referring to the close relations between the governments and the TÜSİAD $(1999,36-37)$.

${ }^{112}$ Yet, as we shall later see, umbrella organisations such as the TOBB made an important come back during the 1990s with the involvement of its (ex)-leaders in national politics and the increasing significance of local business associations - and industrialists in particular - inside the TOBB. 
industry into two specialised chambers can be understood in this sense. ${ }^{113}$ In addition, the promotion of organised industrial districts (OID) by post-1980 governments as a means of stimulating local industrialisation attempts was also important. ${ }^{114}$ The spatial concentration and institutionalisation of local industrial enterprises under the roof of the OID gave them a chance to identify themselves as a "community of local industrialists'. ${ }^{115}$ Gaziantep's OID, as we shall see later, has also constituted one of the most important nodes of agency formation and local political confrontation.

Another important expression of this growing significance of the logic of membership was the emergence of business associations that did not have a public status. These associations proliferated during the 1990s in Gaziantep, and have tended to act as private business clubs. As we shall discuss in detail in chapter 4 , they tend to

\footnotetext{
${ }^{113}$ Yet this did not happen in Bursa, the car-manufacturing centre of Turkey and an industrial workshop for Istanbul. One could argue that Gaziantep has a stronger local industrial bourgeoisie than that of Bursa, although Bursa's economy is apparently more dependent on industry than Gaziantep's. The locally owned industry in Bursa mainly working as subcontractors for the İstanbul-based companies could be considered weak in political terms. Besides, given the close economic relations between Bursa and Istanbul, the big local bosses of Bursa might well have preferred to act as member of the Istanbul Chamber of Industry.

114 Yet, the role of the state in initiation of Gaziantep's OID has been quite limited. Gaziantep's OID is the only privately established and self-financed OID in Turkey.

${ }^{115}$ The first Organised Industrial district of Gaziantep was planned in 1963 by the national government, when the post-coup CHP government was in power. Implementation of this project started in 1969 and the district started to serve in 1973. Now, the fourth phase of the OID is under construction. These districts house medium and large scale enterprises. Unlike its counterparts in other cities, however, establishment and organisation of the OID in Gaziantep has been undertaken by the local businessmen, without getting finance from the government (establishment of a $4^{\text {th }}$ zone is a rare occurrence in other examples).

Small scale enterprises are also organised into separate districts, or traditionally concentrated into the following districts: Örnek Sanayi and Küçük Sanayi Sitesi, Nizip Avenue and its surroundings, Ünald1-Şehreküstü Region. Of these the first two are institutionally organised: The first one was established by a UN project (it literally translated as 'Examplary Industry') (Özsağır 1999: 66-67, Eraydin 2002, 161).
} 
act as the extensions of the local chambers (of commerce and industry) in the civil society of Gaziantep. They not only contributed to the enhancement of the legitimacy of business interests in the city, but also functioned as the political voice of different business interests. In fact, given the official status of the local chambers, the logic of influence inevitably balances out the logic of membership to a certain degree, even in the case of the Gaziantep Chamber of Industry, thereby compelling different business interests to get organised under these private associations to more explicitly express their views, and to pursue their own political agenda.

As mentioned earlier, the post-1980 national accumulation strategy shift and the associated re-scaling of the forms of intervention - and internal organisation - shaped the path of entrepreneurialism in Gaziantep by re-defining the strategies and sites of political representation of Gaziantep's bourgeoisie. The re-scaling of the state interventions, (i) through the introduction of selective, territorially specific support programs, and (ii) through further centralisation of the distribution of individual benefits/incentives was crucial in this respect. Özal's government created new, specialised public bureaucracies ${ }^{116}$ (Güler 1996; Aksoy 2003), alongside the DPT, to be directly controlled by the Prime Minister. The aim was to ease the task of implementing a comprehensive neoliberal transformation. This centralisation process made it more difficult for Gaziantep's local bourgeoisie to make their voices heard in the 'higher

\footnotetext{
${ }^{116}$ These included the institutions like the undersecretariat of treasury and foreign trade. Later on, this undersecretariat was split into two separate undersecretariats of foreign trade and treasury.
} 
bureaucracies of economy'117, thereby pushing them to develop and pursue an aggressive representation strategy targeting these critical nodes of decision-making. At the same time, they were compelled to find ways to compensate for the benefits that could have been captured had Gaziantep been subject to direct state interventions, especially via territorial state schemes. In addition, the ineffectiveness of the available state support ${ }^{118}$ designed to enhance the competitiveness of local industries in the national and international markets, also emphasised the need to formulate compensation strategies. ${ }^{119}$ This, to be sure, required an active strategy of searching for new interlocutors, and establishing connections or alliances with these institutions/actors established at different scales.

To summarise, the local business associations in Gaziantep started to develop "scalar strategies of representation" in the 1990 s as a response to the representational barriers of Özal's clientelism, and to the perceived failure of the 1990s' parliamentarism. Indeed, the clientelism of Özal's Motherland Party came to an end with the party's electoral loss in 1991, which marked the beginning of the period of coalition governments (1991-2002). Despite the fact that the end of the Motherland

\footnotetext{
${ }^{117}$ See, for example, the critisisms of the current presidents of the GTO and the GSO (Aslan 2002; Koçer 2000), as well as the ex-president of the GSO Şerbetçi's annual message in the local journal, Yorum (1996).

${ }^{118}$ Such as R\&D, organisational development, improvement of marketing skills, etc

119 Although there are certain state agencies specifically established to provide such support, their performance falls short of expectancies. In fact, the awareness of SMEs of these non-monetary state benefits is considerably low. According to many interviewees (especially the Esnaf leaders) a good part of the problem is the weakness of such agencies in directly reaching out the local producers, despite the fact that they have local branches in industrialised/industrialising cities including Gaziantep. As we shall later see, only now are such agencies being reformed to enhance their effectiveness in reaching producers.
} 
Party's single party rule brought back parliamentarism, hyphothetically more favourable to the bourgeoisie ${ }^{120}$ (Jessop 1990), the instability of the coalition governments and party-politics (Sayarı 2002, 17; Kalaycıŏglu 2002) prevented it from serving as an effective channel of representation. This political instability fueled economic instability (unstable foreign-exchange rates, high inflation rates, etc), while also rendering the state impotent in taking long-termed policy decisions. The result was an increased pressure on Gaziantep's business associations to search for sites of stability where they could collaborate with different non-(nation) state actors for "long-term" projects that would help them implement their multi-scalar local accumulation strategy. Ironically, due to the earlier centralisation of distribution, the Prime Minister's office continued to bear its significance as a node of distribution of "short-term" benefits in the midst of such a dispersed political structure, and once Özal left the political scene, organised representation of business interests to the Prime Ministers office gained importance.

\section{Conclusion}

This chapter showed that by studying the case of Gaziantep we can gain rich insights into the dynamics behind the rise of the Anatolian Tigers, and can develop a critical perspective that goes beyond the claim that these cities epitomise the success of a new

\footnotetext{
${ }^{120}$ For example, an ex-president of the TOBB, Yalım Erez, also an MP (first from ranks of the True Path Party - the heir of Demirel's Justice Party; later as an independent MP), became the minister of industry and trade in a coalition government. Moreover, when that government dissolved, Erez was given the mission to form a new government by President Demirel. Yet, Erez's attempt was unsuccessful.
} 
economic order where they came to replace the nation state as the new loci of policymaking. In this chapter, I introduced my approach by arguing that we should look closer into the political processes that produced the example of Gaziantep, rather than framing and examining its rise as a purely economic phenomenon. I also claimed that we can understand the increasing political-economic significance and visibility of cities and regions as a product of local agency that emerge as a response to, and to contain, a broader accumulation strategy shift and the associated state re-scaling proces. In the subsequent sections, following my main thesis, I traced the roots of the political activism of Gaziantep's bourgeoisie back to the post-1980 national accumulation strategy shift and the associated state re-scaling process. In particular, I argued that the parallel changes in the political opportunity structure and the forms of representation gave the final push for the political mobilisation of Gaziantep's local bourgeoisie, which is led by its industrial fraction. We saw that the local business association gained significance in this process as strategic venues and agents of representation, whose focus of activity has been re-scaled so as to stretch the territorial reach of local accumulation in Gaziantep, and to respond to the re-scaling of state interventions.

The analytical findings of this chapter indicated that we have to concentrate on the local political processes if we are to understand how the local bourgeoisie activism transformed into local entrepreneurialism in relation to the national accumulation strategy shift and the associated state re-scaling. In particular, it becomes crucial to investigate the changing role and place of local business associations in local politics. Benefiting from the insights provided by literature on the topics of scale and business 
associations, I argued that local business associations have to be actively engaged in coalition-building and lobbying at various scales to strengthen their hand in bargaining with various interlocutors. At this point, the concept of "local corporate regime", which problematises the politico-institutional form of a local entrepeneurialism led by the local bourgeoisie, is of great help in understanding the changing place and role of the local business associations in local politics, and the nature of the (scalar) strategies of representation they adopt. In Chapter 4 , we will concentrate on these dynamics in the case of Gaziantep, and will see that the formation of the local corporate regime in Gaziantep became possible with the second wave of industrialisation earlier depicted in this chapter. Accordingly, the chapter concentrates on the late 1980s and 1990s when the basis of the local corporate regime was laid, and its multi-scalar agenda was formed. Chapters 5 and 6 concentrate on the late 1990s and 2000s when the scalar strategies of representation started to be implemented by Gaziantep's local business associations and the local corporate regime. 


\section{CHAPTER - IV}

\section{"Gaziantep's Local Corporate Regime"}

This chapter focuses on the dynamics of creation of local agency in Gaziantep with a special focus on the post-1980 era. The transition from the first of phase of industrialisation to the second constitutes the context of our analysis. The chapter investigates how the activism of the local bourgeoisie in Gaziantep came about. More broadly, I argue that the local entrepreneurialism in Gaziantep has been organised in the form of a local corporate regime, which can be understood as a set of local governing arrangements based on the leadership of local business associations, in cooperation with a number of other key local institutional actors, including but not restricted to the local government.

This does not refer to a broader informal partnership scheme or an implicit agreement between the local business and the local government based on a land development-oriented local economic agenda. Instead, it involves a set of formal and informal local governance arrangements where the local business associations - in our case those officially established by the state - constitute the institutional centre of local policy-making, while other (non-business) key local players play a supportive role in promoting the policy agenda promoted by these business associations. In this framework, the formal agreement among these institutional players on specific policy 
issues is supported, and coordinated, not only through informal contacts between individual representatives of these institutions, but also through semi-informal arrangements, again, led by the local bourgeoisie. In particular, I am referring to the local business associations that do not enjoy an official, or public, status.

In addition, following the current discussions on urban regime theory, this chapter investigates the formation of Gaziantep's local corporate regime in relation to the broader political-economic context it has been embedded in, rather than concentrating simply on the emerging forms/models of local governance (cf. Austin and McCaffrey 2002, 46; Valler et al. 2000, 418; Pierre 2005). Therefore, the chapter examines the impact of the post-1980 national accumulation strategy shift and the associated state re-scaling - as described in the preceding chapter - on the formation of the local governance arrangements, especially the increasing prominence of the local business associations, and the agenda pursued by the local corporate regime. Here, we note that local corporate regimes can follow different policy agendas (Clark et al. 2001) with different corresponding forms of local governance (cf. DiGaetano and Strom 2003, 366). In our case, to better understand the dynamics of a pro-industrialisation local agenda formation and the central role played by the local business associations in this process, we have to discuss how the logics of membership and goal formation in these associations have altered in a response to the shift in the national accumulation strategy shift. Thus, the analysis of the local corporate formation in Gaziantep begins with an analysis of how the political activism of the local bourgeoisie came about. Only then we 
can proceed to discuss how other key local players stepped in to contribute to the formation of the local corporate regime.

\section{Political mobilisation of the local bourgeoisie}

The 1980s witnessed the rise of local business associations as significant sites and agents of the representation of the local bourgeoisie. Yet, in the case of Gaziantep, it was only in the 1990s that they emerged as influential "political actors", and began to organise other key actors and institutions of Gaziantep's political-economy so as to construct a local corporate regime. The regime's institutional centre and leadership was assumed by the Gaziantep Chamber of Commerce (GTO) and the Gaziantep Chamber of Industry (GSO). In other words, the "agency of Gaziantep as a locality" came with the rise of a politically conscious local bourgeoisie. This rising political consciousness found its expression in the split of the GTSO into two separate chambers, and thus the birth of the GSO, which further enhanced the policy-making and implementation capacity of the local bourgeoisie, both in terms of its industrial and commercial fractions. Of course, political mobilisation of the local bourgeoisie was only one precondition for the creation of a local corporate regime. The second pre-condition was the availability of a business-friendly local political climate where other local actors were ready to cooperate with the local business associations around a pro-business agenda. The re-scaling of the internal organisation of the state, and of the forms of state intervention considerably contributed toward the formation of such an atmosphere. In 
this section, we will take a closer look at the nature of this former development and its implications for the local corporate regime formation. The latter will constitute the focus of the following section.

The industrialisation process of the 1980s produced an industrial bourgeoisie that started to distinguish its identity and interests from those of the smaller fractions of the commercial bourgeoisie. With the coming of the third generation industrialists ${ }^{121}$ in the 1990s, this divide became clearer. As mentioned earlier, the tension inside the GTSO had been present since the late 1970s. By 1989, however, the industrial bourgeoisie was powerful enough to organise itself under a separate chamber. The split had important repercussions for the political mobilisation of Gaziantep's local bourgeoisie and Gaziantep's local politics, which can be understood in three dimensions. First, the activation of the local business associations as (political) representatives of Gaziantep's bourgeoisie (i) through the redefinition of the balance between the logic of membership and the logic of influence; (ii) through the changing content of what these logics stand for; and (iii) through their organisational restructuring with the changing balance between their logics of goal formation and implementation. The second dimension is the emerging division of labour among the local business associations, and between the local business associations and other local actors, in the formation of the local corporate regime. The third involves changes in the direction and dynamics of local agenda creation in Gaziantep.

${ }^{121}$ INTERVIEW WITH AYKUT TUZCU 
The activation of the local business associations as (political) representatives of

\section{Gaziantep's bourgeoisie}

According to those who contributed to the creation of the GSO, the industrialists' problems, visions, and goals were seen as very different from those of the other members of the GTSO, composed of barbers, carpenters, car-maintenance sector, etc. It was felt that each had to have its own organisation so that it could quickly solve its problems. ${ }^{122}$ Thus, one of the most significant concerns behind the creation of the GSO was the need to address the specific problems of the industrial sector. In other words, the "logic of implementation" provided a strong impetus for the creation of the GSO. Yet, as we shall see, this emphasis on "implementation" had a considerably broader scope than simply executing the legally designated functions - like doing the paperwork for certain legal permits, registration, record-keeping etc - on behalf of the state.

The construction of a professional service organisation takes time, and requires the professional help of outsiders. In this respect, the GSO paid special attention to establishing contacts with foreign international organisations and professional consultancy firms in the mid-1990s, bearing fruit by the end of the 1990 s. ${ }^{123}$ In fact, the attempts to improve the organisational quality of the GSO did not stop there. In late 1998, the chamber commissioned a report by the GTZ (the German Technical Collaboration Institution) to determine the future orientation of the chamber. The first

\footnotetext{
${ }^{122}$ INTERVIEW WITH AYKUT TUZCU

${ }^{123}$ The - then - president, now late, M. Kamil Şerbetçi declared that GSO was undergoing a comprehensive organisational re-structuring beginnning from early 1996, with the help of the German Technological Collaboration Organisation (Şerbetçi 1997, 15).
} 
and the most strategic suggestion of the GTZ was a shift in the locus of attention from the chamber's compulsory legal functions to become a service institution relying on knowledge and qualified experts (The GTZ 1998, 1). The re-orientation suggested moves in the direction where membership characteristics were given more emphasis.

The GTZ report had a number of suggestions pertaining to the tension between the logic of membership and the logic of influence, mainly prioritising the former. The above mentioned emphasis on the need to enhance the member-orientation of service provision, for example, could be understood in this sense. But, beyond this focus, the GSO was also given a special mission to promote the local industrial interests through effective political mobilisation. This was necessitated by two pressing needs: a) the need to respond to, and actually to contain, the increasing instability and unreliability of the major existing interlocutor, namely the central government that had been controlled by coalition governments for over a decade (1991-2002); and b) the emphasised need to enrich the portfolio of interlocutors so as to lessen the pressure exerted by the logic of influence over a chamber whose reason d'etre was mainly the logic of membership.

In fact, the GTZ report stressed that while the GSO appeared to be a small chamber in terms of its financial sources, when compared with the İSO (İstanbul Chamber of Industry) (The GTZ 1998, 3) its political mobilisation capacity was much higher, thanks to its emphasis on the logic of membership and its entrepreneurial approach (under the leadership of Nejat Koçer). According to the report, this made the GSO one of the four top chambers in Turkey in terms of effectiveness, organisational 
efficiency, and political influence. ${ }^{124}$ Building upon this observation, the report suggested that the GSO use this capacity to construct and pursue a clearly-defined political agenda with longer-term considerations. What was especially striking about the report's suggestions was the emphasis on active coalition building to facilitate a medium-term reform program that would be attractive to the constituency (the voters as ordinary people):

What is advised to the GSO, to increase its influence, is not to isolate itself from others but to collaborate with them. The GSO should try to establish dialogue and should try to create a consensus by working with other social groups and institutions to come up with a medium term reform program which will be attractive to most of the constituency. [It] should be honest with the people. [It] should stay in dialogue with MPs and party leaders, and improvement of its position should be maintained without prioritising any party. ... The GSO, to be able to be more influential in the TOBB, has to enter into collaboration with other chambers of industry, [and] should concentrate on issues of strategic importance (The GTZ 1998, 5). ${ }^{125}$

The suggestion that followed was to introduce some organisational changes to facilitate such a coordinating function $(1998,5)$. The report also suggested that the chamber of industry should actively engage in image-building and promote Gaziantep at the international level $(1998,2,4)$. As we shall see in the coming sections and chapters,

\footnotetext{
${ }^{124}$ In fact, the GSO, along with 42 other chambers in Turkey, applied for an accreditation program, a collaboration of Eurochambers (Union of European Chambers of Commerce and Industry), Union of British Chambers and the TOBB. The GSO made it to the first shortlist of 10 chambers, and then to the first four chambers in Turkey, in terms of the organisational quality, and eventually participated in the certificate program (Değişim March-April 2003, 11).

${ }^{125}$ This text has been translated from Turkish by the author.
} 
these suggestions have been taken seriously by the executives and bureaucrats of the $\mathrm{GSO}^{126}$, and the GSO's agenda began to dominate the local politics in Gaziantep.

We can summarise the (intra)organisational tensions that led to the emergence of the GSO, and thus informed its priorities, as shown in Schema 4.1. On the one hand, the industrialists' departure from the GTSO led the GSO to establish itself at a point closer to the logic of membership on the continuum. Yet, the GSO's position has to be seen and presented as a middle point between the logic of influence and the logic of membership. Here, we should remember that the logic of influence continued to exercise its influence mainly due to the public status of the GSO, as the official representative of Gaziantep's industrialists before the state. Of course, the scalar strategies of representation that were adopted from the mid-1990s onwards can be seen as attempts to lessen the pressure of the logic of influence, rooted in this offical status of the GSO.

On the other hand, simultaneous moves to mobilise the chamber in political terms and to reinvent its service orientation located the chamber at another middle point on the continuum between the logics of goal formation and implementation. We have to note that although the demands of the membership provided the impetus behind the establishment of a separate chamber of industry, it is hard to argue that all these demands were effectively incorporated into the "goal formation" process. This has much to do with the unbalanced composition of representation inside GSO and the

\footnotetext{
${ }^{126}$ If we are to give few examples in that regard: the president of GSO succeeded in getting elected as the vice-president of TOBB, and GSO initiated the trademark city project (as we discussed in the preceding chapter).
} 
nature of its leadership, characterised by the dominance of the textile sector (the thread sector in particular) and the SANKO holding.

Schema 4.1: The (intra)organisational tensions that led to the emergence of the GSO
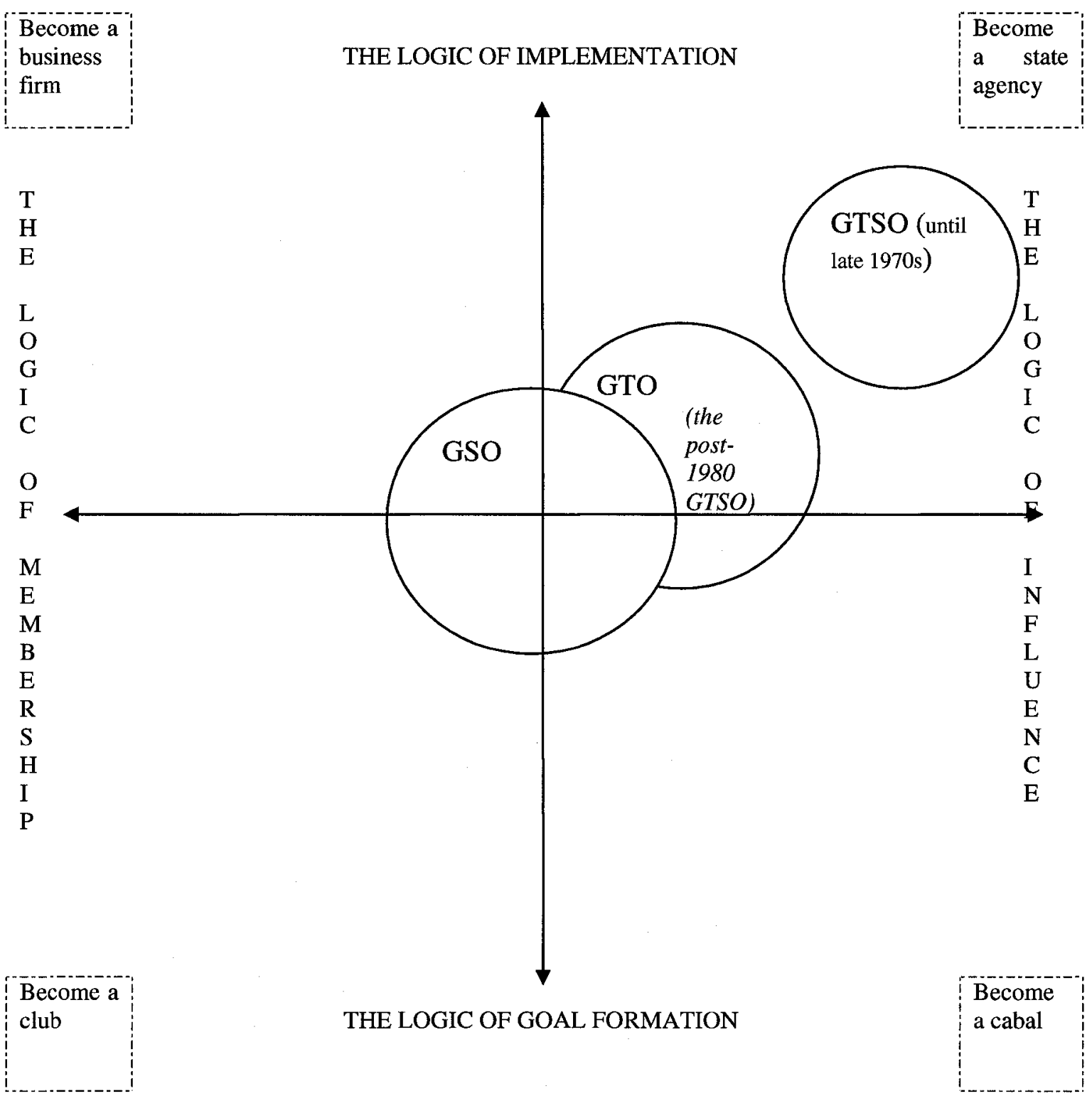
Table 4.1 indicates that the enterprises in textile, food, chemical products, and construction sectors were large enough to become GSO members. ${ }^{127}$ The textile sector makes up almost half of the membership of GSO: 630 out of 1317 members of the GSO are from textiles. In particular, it is especially the thread sub-sector that is dominant. Abdulkadir Konukoğlu (SANKO), one of the most prominent thread producers in the country, is the president of the GSO assembly. Nejat Koçer, the president of the GSO, is also the owner of a thread producing firm. Ironically, this representation structure gave a certain degree of coherence and permanency to the policies pursued by the GSO, by stabilising its decision-making process.

Table 4.1: The industrial enterprises in Gaziantep and the membership Structure of the GSO

\begin{tabular}{|l|l|l|l|}
\hline Sector & GSO member & Other & Total \\
\hline Textile & $\mathbf{6 3 0}$ & 940 & 1570 \\
\hline Food & $\mathbf{2 0 6}$ & 242 & 448 \\
\hline Chemical & $\mathbf{1 8 6}$ & 199 & 385 \\
\hline Metal works & $\mathbf{1 2 8}$ & 309 & 437 \\
\hline Car (supplementary) & $\mathbf{3 5}$ & 234 & 269 \\
\hline Construction & $\mathbf{6 1}$ & 76 & 137 \\
\hline Forestry & $\mathbf{1 8}$ & 145 & 163 \\
\hline Paper & $\mathbf{3 5}$ & 171 & 206 \\
\hline Electrical/electronic production & $\mathbf{1 2}$ & 65 & 77 \\
\hline Other & $\mathbf{6}$ & 0 & 6 \\
\hline TOTAL & $\mathbf{1 3 1 7}$ & 2381 & 3698 \\
\hline
\end{tabular}

Source: GSO (2003)

\footnotetext{
${ }^{127}$ In fact, for the textile sector, it gives the impression that the average size of the enterprises is small in this sector. Yet, this is only true for a few of the sub-sectors such as of blanket production and confectionary production, which make up more than 700 of the 940 non-GSO-member enterprises.
} 
In sum, the GSO emerged as a business association where the logics of membership and goal formation received greater emphasis than they had in the GTSO of the pre-1980 period. Moreover, the GTSO was already undergoing a transformation with the increasing pressure of the logic of membership that found its expression in the struggle between the İstanbul-based capital and the Anatolian capital. As the following statement from Mr. Geylani confirms, revival of the GTSO occurred at a time when the TOBB had been shaken by these highly politicised intra-bourgeois struggles of the 1970s:

I came to the chamber in 1977. They were times of our burgeoining in commerce. A long road has been taken since then. With the economic development of Gaziantep, the chamber itself, the way it works ... and its face .... its vision, its mission have changed. It has turned from a rubber stamp organisation into an organisation producing/generating projects. This change came with our taking the old thinking down. During the chamber elections of 1977, we were young people of 25-27-29 years of age. That group of ours became successful. There used to be people of 60 years old. We took over the management. We have been working since then. Now we got old too. There is a need for young fellows to replace us ... to carry the chamber higher. ${ }^{128}$

The transformation of the Gaziantep's Chamber of Commerce and Industry started towards the end of the 1970s, when the engagement with the state (and national politics) via a nationally organised channel of representation had proven disastrous. They were caught between Süleyman Demirel, who had been in power for most of the 1970s as the Prime Minister, and Necmettin Erbakan, who controlled the ministries of

\footnotetext{
${ }^{128}$ Geylani served as the president and the assembly president of the GTSO (then the GTO) for more than a decade (INTERVIEW WITH MUSTAFA GEYLANI).
} 
trade, industry and economy in the coalition governments. In a context characterised by political instability and economic crises, the local bourgeoisie eventually found its own - already existing - business association as the last resort for defence of its interests, rather than their own national umbrella organisation. Thus, it is not surprising that a more activist group took over the chamber in the late 1970s. Its challenge was to redefine the role and the nature of the chamber as an institutional channel and vehicle for political-economic mobilisation. In this respect, the logics of goal formation and membership received greater emphasis in the GTSO. Yet, there were two factors that prevented the GTSO from becoming an adequate political representative of the local bourgeoisie during the 1980s. First, it lacked a fraction of capital strong enough to give a coherent sense of interest definition within the GTSO. ${ }^{129}$ In addition, the diversity of interests and sectors represented under the GTSO made it difficult for it to be dominated by the logic of membership. The only motivating factor behind this mobilisation, then, was the recognition of the need to promote the cause of Gaziantep's local bourgeoisie in general. ${ }^{130}$ Second, despite the fact that the new ruling group of the GTSO was eager to

${ }^{129}$ A careful look at the names on the executive boards of GTSO throughout its history (Pekdoğan 1999), as well as informally transmitted information by the insiders indicate that the group that has lead the GT[S]O since the late 1970s was a tightly knit group, part of the older and stonger families of Gaziantep (Informally transmitted insights of Dr. BÜLENT YILMAZER and Mr. ZIHNI KEPKEP; INTERVIEW WITH ASIM GÜZEL). This situation did not change until the late 1980s. By the 1990s, the number of economically powerful entrepreneurs other than older families of Gaziantep had considerably increased, and diversification of their interests along sectoral lines had become emphasised.

${ }^{130}$ In the case of Gaziantep, this recognition was shared by the commercial fraction of the local bourgeoisie, too, despite the fact that, in general, commercial capital in Anatolian cities in general had better ties with the İstanbul-based large scale capital, as well as the Demirel governments that controlled the apex of the TOB (later the TOBB). Here, we should remember that Mr. Geylani himself is a prominent tradesman, and continued to serve as the president of the GTO, and later its assembly, after the split of the GTSO. This preference of Gaziantep's local traders to pursue an independent localist strategy 
develop a vision for the chamber, and that the dispersed representation structure of the chamber gave it the freedom to define its status as 'above all sectoral interests', the logic of goal formation could become effective only with a substantial increase in the policy-making capacity of the chamber. This could take place only with the help of a major restructuring involving considerable investment in human resources and organisational development that would strengthen the chamber's capacity to the better define the policy problems and to come up with concrete solutions to put on the table before the interlocutors. For the GTO, this came only after the split of the GTSO.

Although the split of the GTSO did not produce a political polarisation inside Gaziantep's bourgeoisie, it fueled a "covert" (The GTZ 1998) and "friendly"131 competition between the GTO and the GSO on organisational grounds. ${ }^{132}$ This contributed to the improvement of the organisational and professional competencies of both chambers, which turned the representative organisations of the local bourgeoisie

could be related to the nature of Gaziantep's trade relations, which heavily relied on cross-border trade with Syria and other Middle-East countries, thereby giving them a degree of autonomy from the domestic power relations between Anatolian commercial bourgeoisies and the İstanbul-based large scale capital.

\section{${ }^{131}$ INTERVIEW WITH MUHARREM BALAT}

${ }^{132}$ Interestingly, during our interview, the general secretary of GTO also made the claim that GTO is in the ivy league of Turkish chambers - in the first three or four (INTERVIEW WITH MESUT ÖLÇAL). According to the officials (and ex-officials) of the GTO, the chamber works quite efficiently. For the first time in Turkey, a chamber hired staff via an entrance exam supervised by Gaziantep University. The GTO has hundreds of employees of high quality, an organisational feature which possibly no other institution possesses in Gaziantep (including the Greater Gaziantep Municipality). One does not need to look further than the annual information booklets produced by the GTO and the Local Branch of the Ministry of Trade and Industry $(G b F 2000 ; 2001 ; 2002 ; 2003 ; 2005$; Gaziantep Sanayi ve Ticaret İl Müdürlüğü 1998; 2000; 2001). For example, the data about different aspects of Gaziantep's economy was not updated between the 1998 and 2001 issues of the reports prepared by the local branch of MTI! The report prepared by the GTO, however is an annual update of economic activities in Gaziantep as well as its social, economic, and cultural aspects (readers can find the 2005 version of GbF on the website of the GTO: www.gto.org.tr). Here, the GTO is acting like / and indeed replacing the state as the "elder brother" of Gaziantep, having a better grasp of and control over the conduct of local affairs. 
into the intellectual centres of Gaziantep. In this respect, the comment made by Mesut Ölçal, (the head of the GTO's bureaucracy since 1984), makes sense: “The GTO works as the elder brother of the civil society organisations in Gaziantep, ahead of them, showing them the way, transferring them information/knowledge, sometimes, solving the problems that such organisations cannot solve by themselves." 133 Thus, the increase in the professional strength and policy-making capacity has had two consequences in terms of the role and place of these chambers in local politics: a) increasing credibility and reliability of the GTO and the GSO in the eyes of the local public and local institutions; b) increasing credibility and reliability of these chambers in the eye of the state bureaucracy and governments. Both secretaries, as well as the presidents of the GTO and the GSO, argue that they never go to Ankara or to a local government (to demand something) without taking their own clearly stated solutions and alternatives along, unlike other chambers from Eastern and Southeastern provinces whose interaction with the state remains within boundaries of demands for state investments. ${ }^{134}$

Why did the split not lead to the emergence of a political rivalry between the GTO and the GSO? In fact, the group currently ruling the GSO had already become dominant inside the GTSO before the split. ${ }^{135}$ Yet, the successful attempt of these powerful industrialists to establish a separate chamber did not lead the GTO to pursue a different political agenda, despite the fact that certain industrialists fiercely opposed the

\footnotetext{
${ }^{133}$ INTERVIEW WITH MESUT ÖLÇAL

${ }^{134}$ INTERVIEWS WITH MESUT ÖLÇAL AND KÜRŞAT GÖNCÜ.

${ }^{135}$ INTERVIEW WITH TURGUT ERCAN
} 
split on the grounds that this could well prepare the conditions for potential rifts between these two chambers, if controlled by rival groups. ${ }^{136}$ There are two possible reasons for this. First, the cross-membership between these organisations ${ }^{137}$ was an important factor that gave coherence to the policies of the GSO and the GTO. This was inevitable given the fact that the current industrialisation process is a product of the traders' investing in industrial production. Although the GSO does not have information regarding the exact number of industrialists that are members of both chambers, we can get a picture of the cross-membership by using the information on the distribution of export incentives (Table 3.4). Given that it is usually the larger and successful firms that receive the export incentives, we could argue that the recipients of these incentives are mostly members of the GSO. According to the information given by the Undersecretariat of Foreign Commerce, $39 \%$ of the recipients are both exporters (traders) and manufacturers (industrialists). This suggests that more than one third of the GSO members are likely to be members of the GTO, too. ${ }^{138}$ Second, the organisational characteristics of these chambers, as described above, left enough room for their leaders to maneuver in formulating the official interests of their chambers. Thus, it was easier for them to reach inter-chamber compromises, while suppressing the

\footnotetext{
${ }^{136}$ INTERVIEW WITH ALİ BURNUKARA

${ }^{137}$ INTERVIEW WITH KÜRŞAT GÖNCÜ.

${ }^{138}$ Please note that 1685 incentives were given to manufacturing firms. The GSO has currently 1300 members $(G b F 2005,39)$. Although we do not have the information of how many incentive certificates were given to any individual firms, we could argue that the GSO membership is benefiting from the incentives extensively. Thus the representativeness of the $39 \%$, and its level of accuracy should be high.
} 
emergence of interest formulations based on sectoral differences that initially produced the split of the GTSO.

The emerging division of labour among the local business associations

To re-iterate, the local bourgeoisie established itself as the central actor of Gaziantep's local politics, and organised the city's politics in the form of a local corporate regime especially from the 1990 s onwards. The local bourgeoisie had to re-institutitonalise its representation structures before it could start to organise cooperation among the key local actors around a pro-business agenda. In this respect, the split of GTSO was the most important step forward. As the major official representatives of the commercial and industrial fractions of the local bourgeoisie, these chambers constituted themselves as the major policy-makers of Gaziantep, able to impose their agenda on the city's other key institutional players, and capable of producing concrete projects to pursue a multiscalar accumulation strategy.

In this grand schema, the GSO has constituted itself as the 'agenda-setter' of the local corporate regime. As mentioned, a number of factors, a) including the specifity of interests and the emphasised logic of membership, b) the chamber's attempt to promote a pro-industrial, multi-scalar local accumulation strategy, and c) the weight of its membership in Gaziantep's economy, turned the GSO into a political agent that constantly negotiated the boundary between the local and non-local, exploring and introducing new agendas, thus becoming the agenda setter of the local corporate regime. The internal representation structure of the GTO and the nature of its membership 
would not allow the chamber to be as effective as the GSO in formulation and determination of a specific agenda. Although the GTO assembly is made up of representatives from each sector, each represented equally by two members, communication between the GTO and its constituency is not as effective as it might be. ${ }^{139}$ The communication problem narrows the intra-organisational goal-formulation process onto a smaller group of people in charge of the administration. This makes the emergence of a proper sectoral view, capable to being defended on the platform of the GTO assembly, quite problematic. The professional groupings under the GTO bring together competing groups whose interests can clash. ${ }^{140}$ In addition, with the exception of the industrialists who are also members of the GTO, the economic power of the members represented under different sectoral groups is less than that of the GSO members. The GTO performs a rather different function. It serves as a 'source of cohesion' among different fractions of Gaziantep's bourgeoisie due to its historical role in Gaziantep's political economy. Of course, the size of its constituency is a significant factor in enhancing the legitimacy of the GTO's claim to be the "Elder Brother" 141 of Gaziantep. Currently, there are 24,683 registered members $(9,977$ of them are active members) ( $G b F 2005,39)$, who are organised under 36 different sectoral committees.

\footnotetext{
${ }^{139}$ An ex-president of the GTO - and also of the GTO assembly - stressed that even though they try to do their best to stay in contact with their membership, it is still difficult to reach them. He, for example, complained about the lack of interest on the side of the membership, and mentioned that they did not even bother to respond to a small questionnaire (INTERVIEW WITH MUSTAFA GEYLANI).

${ }^{140}$ Such as the construction sector where the housing cooperatives, builders, architects (owner of architecture companies) are brought together (INTERVIEW WITH ASIM GÜZEL).

${ }^{141}$ INTERVIEW WITH MESUT ÖLÇAL.
} 
A note of caution is due here. The membership base of the GTO and the GSO combined constitutes around one third of the entrepreneurs in Gaziantep. The rest, composed of petty traders and artisans, i.e, the Esnaf, are organised under a separate local union of numerous sector-based chambers (like the Gaziantep's Chamber of Grocery Store Owners, or the Gaziantep's Chamber of Furniture Producers), namely the Gaziantep Union of Chambers of Petty Traders and Artisans (Gaziantep Esnaf ve Sanatkar Odaları Birliği - GESOB), which is represented by the TESK at the national level. Despite the fact that the GESOB has a large membership base with a strong guild tradition and sense of sectoral solidarity ${ }^{142}$, and that such micro-enterprises considerably contribute to the employment in the city ${ }^{143}$, Esnaf remains at the periphery of the local political arrangements and the local policy-making scene.

\footnotetext{
${ }^{142}$ According to Bianchi, there is an inverse relationship between the level of industrialisation in a region and the strength of Esnaf (i.e, small entrepreneurs, be it in trade or manufacturing). Yet, in Southern Turkey, where Gaziantep is located, "the Mediterranean's concentration of industrial investment has not seriously weakened its highly diversified small-scale industries. In contrast to their counterparts in the Black sea area, the craftsmen of Gaziantep, Hatay, and Adana have developed one of the nation's largest networks of local esnaf associations. ... the overall pattern of class associability in the Mediterranean shows strong organization among the traditionally important esnaf and agricultural sectors" (Bianchi 1984, 184-185).
}

${ }^{143}$ According to the data provided in "Gaziantep by Figures" published by GTO, distribution of the economically active population in Gaziantep (the census results of 1990) is as follows:

\begin{tabular}{|l|l|l|}
\hline & Number & $\%$ \\
\hline Employee & 158,698 & 42 \\
\hline Employer & 6,384 & 2 \\
\hline Self-employed & 88,297 & 23 \\
\hline Unpaid family worker & 128,658 & 33 \\
\hline
\end{tabular}

Source: $G b F(2001)$.

Here the category "self-employed" refers to those who run their own business and is closer to our own description of Esnaf. It is also likely that those included into the category of "unpaid family worker" also work for/with those mentioned as "self-employed" (Here, we have to note that the agricultural production, the sector that typically employs unpaid family worker, is relatively insignificant in Gaziantep due to the fact that the province of Gaziantep has limited agricultural land). Indeed, one of the oft - repeated characteristics of business in Gaziantep is that of a "family business", and this is true even for big holdings and companies (Ayata 1999; Eraydin 2002). Here, we can make a rough calculation 
The informal nature of the esnaf solidarity and the institutional structure of its representation pose the most important barriers to the transformation of Esnaf into a significant local political actor (see Chapter 2). An important difference between the TOBB chambers and the TESK chambers is that, in the case of the TOBB, there is a single (provincial or sub-provincial) chamber of commerce and/or industry with a single chamber assembly where all sectors are equally represented. Sector specific issues are dealt with initially at the level of sectoral committees but the decision-making organ is the assembly. Thus, a local chamber of trade and industry could speak with a single voice on behalf of all sectors. In the case of the TESK chambers, however, there are two levels of local representation: first the sectoral local chambers, then the provincial union under which the sectoral chambers operate. The sectoral dimension of organisation makes the local unions of petty traders and artisans more effective in keeping the informal links with their own constituency alive. Yet, this also creates a rather dispersed decision-making structure and renders it extremely difficult to form a common political front among different sectoral chambers. This is especially true for relations between the political parties and these sectoral chambers. Indeed, unlike the TOBB chambers, these sectoral Esnaf chambers are more vulnerable to party-politics, and different chambers often associate themselves with different political parties. ${ }^{144}$ Hence, it

by adding up the last three categories - assuming that the category of "employer" most probably includes owners of small enterprises with less then 10 workers - we find that around 56 to $58 \%$ of the economically active population are directly involved in the economic activities of the Esnaf sector.

${ }^{144}$ INTERVIEWS WITH VAKKAS KATIRLI, COŞKUN KINACIGİL AND ABDÜLKADİR ATEŞ. 
becomes much more difficult for the GESOB, as their local umbrella organisation, to speak on behalf of all Esnaf.

These factors, when combined with the economic weakness of its membership and the lack of resources that could be dedicated to institutional development, seriously restrict the GESOB's capacity to define and promote a concrete agenda. Instead, the dominance of the logic of membership at the level of sectoral chambers and the vulnerability of Esnaf to party-politics force the ruling cadres of the GESOB to work by the logic of influence. Overall, the GESOB, as it stands, mainly serves as a state agency rather than a proactive local political actor representing Esnaf interests (Schema 4.2), leaving the questions of goal formulation and political representation to the GTO and the GSO, thereby following their leadership in local politics. At certain points, the GSO and/or the GTO step in to fill the vacuum created by the GESOB's inability to fulfill certain functions, including goal formation and the expansion of the range of services provided to industrialists, i.e re-formulation of the logic of implementation. For example, the general secretary of the GSO notes that the policies and the programs they develop also target the problems of artisans, micro-scale entrepreneurs who are currently represented under Esnaf chambers, and that the GSO acts as the representative of the concerns of all industrialists in Gaziantep. ${ }^{145}$

\footnotetext{
${ }^{145}$ (INTERVIEW WITH KÜRŞAT GÖNCÜ) The data from the GSO (2003) indicates that only 1317 out of 3698 industrial enterprises are members of the GSO. 2381 of them, in other words, are members of the Artisan and Esnaf chambers. This is especially true for the carpet and blanket producers (497 out of 657 enterprises are members of the Artisan and Esnaf chambers) - and this sub-sector constitutes more than $1 / 3^{\text {rd }}$ of the enterprises in the textile sector (there are 657 carpet/blanket producers, and 1570 textile related enterprises in total). This is also true for garment production where, $2 / 3^{\text {rd }}$ of the enterprises in this sub-branch are operating outside the institutional boundaries of the GSO. What is striking about these two
} 
Schema 4.2: The current institutional landscape of local business associations in Gaziantep
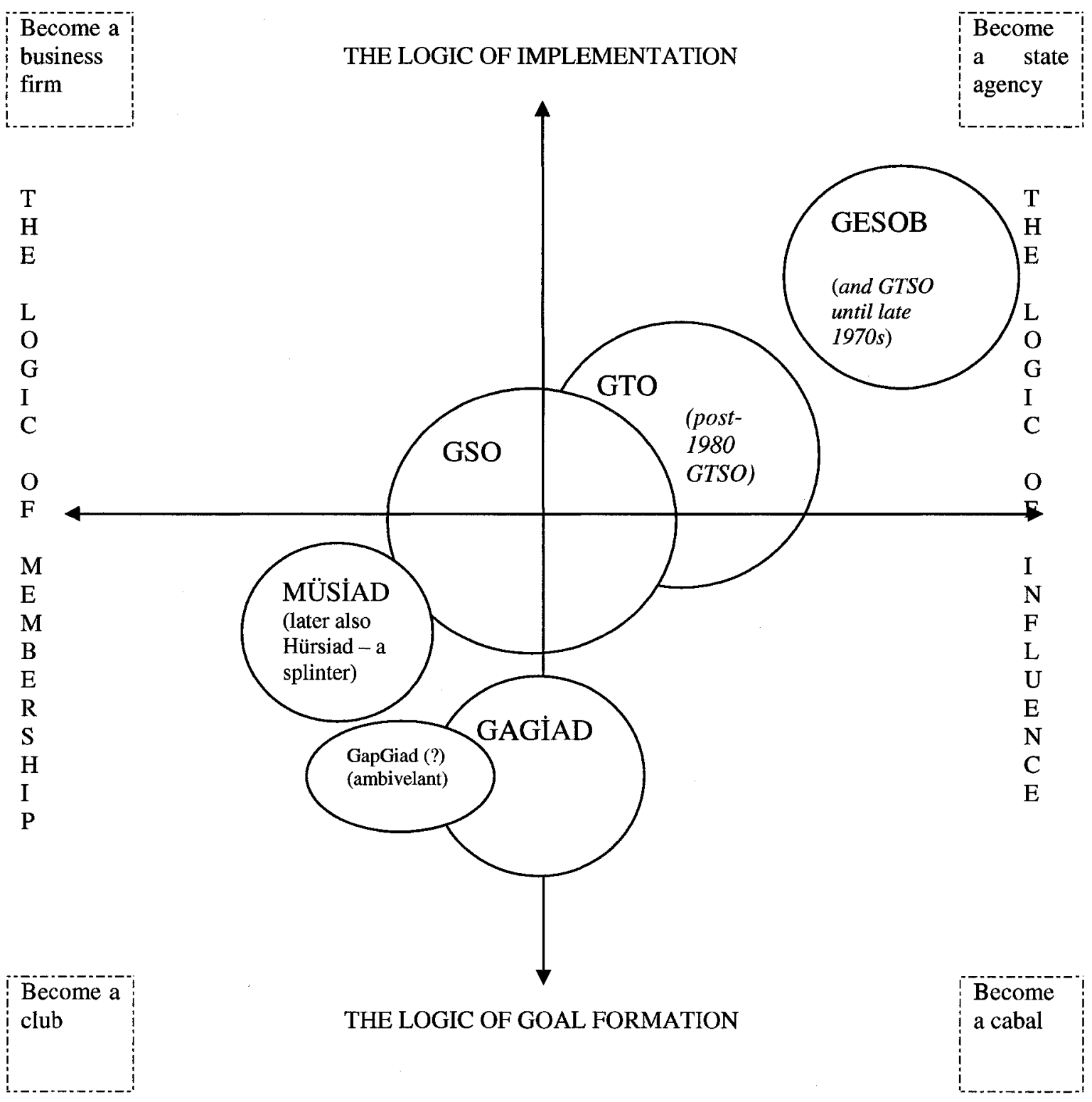

sub-sectors is that they are main consumers of the intermediary goods produced by cotton processing and thread producing large scale enterprises, the most significant one being the SANKO holding, whose boss is also heading the GSO assembly. Thus, the institutional divide reflects, to a certain extent, the sectoral production relations as well (cf. Ayata 1987, 103). Nevertheless, such a divide does not seem to have produced an intra-sectoral tension. One important reason behind this could be the informal relations between the leaders of these sectors. For example, the president for the chamber of carpet producers, Mr. Yalçın Konukoğlu is the cousin of Mr. Abdulkadir Konukoğlu. 
Although the split of the GTSO and the birth of the GSO helped Gaziantep's bourgeoisie, and especially the industrialists, to turn themselves into the central political actor, the official status of the GTO and the GSO, and the inner-representation structure did not allow them to serve as platforms where different interests within the (industrial) bourgeoisie were openly and freely negotiated. In this context, the logics of goal formation and membership led to the emergence of a new sort of business association, namely SİADs (Sanayici ve İşadamları Dernekleri - Industrialists and Businessmen Associations) and GİADs (Genç İşadamları Dernekleri - Young Businessmen Associations) in the 1990s. Unlike the GSO and the GTO, such business clubs/associations had a private status (Schema 4.2).

This informal form of organisation was needed, a) to ferment new ideas so as to contribute to the goal formation process and to freely promote political agendas; $b$ ) to create a sense of class solidarity, and c) to organise other civil society organisations in the city around the agenda of the local corporate regime. In this respect, they could be understood as the rather informal extensions of the GTO and the GSO into Gaziantep's civil society, and into the local and national business community, responsible for feeding and conducting the functions implied by the logics of membership and goal formation.

Gaziantep was not the only city where this mushrooming of private business $\begin{array}{lllll}\text { associations could } & \text { be } & \text { (Kayhan }\end{array}$ http://www.tusiad.org.tr/yayin/gorus/31/html/sec3.html). Nevertheless, it was one of the cities where the local bourgeoisie was especially active in establishing such 
associations. According to one observer, while Gaziantep has 18 associations related to the city's economic development, İzmir - an industrialised metropolitan city - has far fewer. ${ }^{146}$ This is also true when the same comparison is made with the provinces of the GAP region. When we look at the rate of association membership in GAP cities, it is especially high in Gaziantep. The situation is not the same for other provinces (Table 4.2).

Table 4.2: Pattern of Institutional Membership of the Executives of Industrial Enterprises in the GAP region

\begin{tabular}{|c|c|c|c|c|c|c|c|}
\hline $\begin{array}{l}\text { The } \\
\text { organisation of } \\
\text { membership }\end{array}$ & $\begin{array}{l}\text { Adıyaman } \\
\text { (16) }\end{array}$ & $\begin{array}{l}\text { Batman } \\
(9)\end{array}$ & $\begin{array}{l}\text { Diyarbakir } \\
(23)\end{array}$ & $\begin{array}{l}\text { Gaziantep } \\
\text { (18) }\end{array}$ & $\begin{array}{l}\text { Mardin } \\
(48)\end{array}$ & $\begin{array}{l}\text { Şanlıurfa } \\
\text { (34) }\end{array}$ & $\begin{array}{l}\text { Total } \\
(152)\end{array}$ \\
\hline & $\%$ & $\%$ & $\%$ & $\%$ & $\%$ & $\%$ & $\%$ \\
\hline $\begin{array}{l}\text { Private } \\
\text { association }\end{array}$ & 19 & 11 & 26 & 50 & 23 & 6 & 22 \\
\hline Sports Club & 6 & 11 & 9 & 28 & 8 & 3 & 9 \\
\hline Cooperative & - & - & - & - & 6 & - & 2 \\
\hline $\begin{array}{l}\text { Professional } \\
\text { Chamber }\end{array}$ & 75 & 89 & 82 & 89 & 50 & 71 & 70 \\
\hline Other & - & - & 4 & - & 4 & - & 2 \\
\hline None & 25 & 11 & 9 & - & 29 & 23 & 19 \\
\hline
\end{tabular}

Source: Adapted from Paksoy $(2002,85)$

Note: Kilis has only 4 managers and is therefore excluded from the total.

There are four important private business associations in Gaziantep: the GAGİAD (Gaziantep Genç İşadamları Derneği - Gaziantep Young Businessmen’s Association), the MÜSİAD (Müstakil Sanayici ve İşadamları Derneği - Independent Industrialists and Businessmen's Association), the HÜRSİAD (Free Industrialists and

${ }^{146}$ INTERVIEW WITH SOREN HJORTH 
Businessmen's Association), and the GAPGİAD (Gaziantep Paylaşımcı Genç İsadamları Derneği - Gaziantep Sharing ${ }^{147}$ Young Businessmen's Association) (Schema 4.2). Of these associations, especially the GAGIAD and the MÜSİAD play key roles in Gaziantep's politics and local intra-bourgeoisie affairs. The GAPGIAD and the HÜRSİAD, respectively, are splinter organisations of the former associations. They are relatively new associations, and their impact on local political-economy is still limited.

The establishment of the GAGIAD (in 1993) reflects the changes in the socioeconomic composition of the local bourgeoisie in Gaziantep. Its membership comprises the new - third - generation industrialists in Gaziantep, who mainly become true professional - industrialists, unlike their fathers who started up their industrial enterprises using the capital accumulated via commercial activities. Sixty-one percent of the respondents from Gaziantep involved in Paksoy's study are younger than 40 years old (see Table 4.2 above; Paksoy 2002, 58). In other words, it is this age group the third generation - who are the constitutency of the young businessmen associations, and SİADs. This indicates that there is a certain level of institutional mobilisation on the part of the younger managers and/or owners of especially large scale businesses in Gaziantep. $^{148}$

${ }^{147}$ The Turkish word "paylaşımc" - an adjective - would be literally translated as "(those) who (are
willing to) share", which denotes that the organisation emphasises solidarity. Yet with whom the
membership will be in solidarity with is not clear (it does not tell us exactly if the membership has social
concerns, or if they are after a closer collaboration between the young business people). Unfortunately,
the president of the GAPGİAD could not be interviewed. 148 The study focuses on the industrialists who are members of chambers of industry I commerce+industry. Thus the scale of enterprises tends to be large. Another important point to underline is that the rate of return of the questioannaires, in the case of Gaziantep, was quite low: 18 out of 100 . The number of 100 was chosen to be representative of more than 460 industrial enterprises. Hence, I still 
In the journal Genç Çizgi (The Young Line) published by the GAGIAD, we find a number of articles written by the prominent names of Gaziantep, reflecting on the role of the GAGIAD. For instance, Celal Doğan observed that when the sectoral chambers [read the GTO and the GSO] became inadequate, a new type of organisation emerged: business associations, established outside the official boundaries of the chambers of commerce and industry, which do not have public status (Genç Çizgi 4(9), 16). In fact, the GAGIAD has become the place where the leaders of these chambers are educated and prepared for leadership. Nejat Koçer, current president of the GSO, and and expresident of the GAGIAD ( $3^{\text {rd }}$ term), calls the GAGIAD a school for young business people and for Gaziantep (Genç Çizgi 4(9)). Another ex-president $\left(4^{\text {th }}\right.$ term) of the GAGİD, Mustafa Topçuoğlu, commented that the solidarity between members of the GAGIAD turns them into the infrastructure of the economy, social and cultural institutions of Gaziantep'. The GTO, the GSO, Gaziantep Organised Industrial District, Exporter Unions, political parties and the presidents, and executive board members, of many social and cultural institutions in Gaziantep are members of the GAGIAD (Genç Çizgi 4(9), 20). This suggests that the production of solidarity inside the local bourgeoisie has become more formalised, compared with the generation that took over the GTSO in the late 1970s. The 'third generation' is on the rise, more conscious about

take these numbers as proxy variables of membership, and not an exact picture of the situation. It may also be the case that, it is especially the most politically conscious / open-minded executives who preferred to join the survey and fill in the questioannaire. Yet, I think, this is also true for other provinces too, where, the rate of return was also quite low (with the exception of Mardin) (see Paksoy 2002). 
itself as a class, better organised and politically committed. ${ }^{149}$ This new group has stronger roots in the industrial sector than in the commercial sector. Therefore, the GAGİAD also serves as an institutional locus for the formation of new coalitions across different institutions, which could shape the future economic agendas of Gaziantep, especially around industrial concerns. ${ }^{150}$

Another significant business association of interest is the MÜSİAD. It was established in 1990 as a voluntary national business association. Owners of small and medium entreprises from Anatolian Tigers constituted its membership. The main ideological concern of the MÜSİAD was the same as that promoted by Necmettin Erbakan, who raised the flag of Anatolian capital against mainly İstanbul-based big capital in the 1970s. In fact, the emergence of the MÜSİAD coincided with the rise of political İslam in Turkey in 1990s, under the leadership of Erbakan's Welfare Party, and the MÜSİAD functioned as an extension of this political movement in the business world (Öniş 1997; Demir et al. 2004). ${ }^{151}$ Nevertheless, the political success of Erbakan's Welfare Party was short-lived. As we shall later discuss in detail, the military

\footnotetext{
149 See for example the decleration of GAGIAD's views on national politics, soon after Mr. Koçer became its president (Yorum 1, 9-10).

${ }^{150}$ Here it is also important to see that the sort of a tension inside GSO could also stir GAGIAD as the representative organisation of all up and coming business people of Gaziantep. The creation of the GAPGİAD (Gaziantep Paylaşımcı İşadamları Derneği - Gaziantep Young Sharing Businessmen's Association) as an alternative to the GAGİAD could well be an instance of this transformation process. Nevertheless, this is a very speculative statement. Besides, when we check the websites of both organisations, we come up with the same names as members of both organisations (www.gagiad.org.tr ; www.gapgiad.org.tr). Here, what we observe could well be a process similar to what happened in the case of the split of GTSO, which took place, partially, for functional reasons.

${ }^{151}$ Here, we should note that the party in power today, AKP, is a splinter party from Erbakan's 'Welfare later Virtue - Party'.
} 
memorandum of February 28, 1997 paused this remarkable rise of political İslam, and harmed the political representation capacity of the business interests affiliated with Erbakan's Welfare Party. According to Özcan, "after the unsuccessful engagement of the MÜSİAD into Islamist politics in Turkey, it lost supporters and a splinter group, the HÜRSİAD emerged in Gaziantep and other provincial towns. Meanwhile the MÜSİAD also lost popularity in Denizli and Kayseri" (2000, 230-231).

Yet, the group of traders and industrialists in Gaziantep who gathered under the umbrella of the MÜSİAD did not lose their political influence. If anything, they became more influential. The Gaziantep branch of the MÜSİAD was established in 1993, and has been led by the Nakıpoğlu Family ${ }^{152}$ (Özcan 2000, 229). In fact, the 2003 elections for the managerial board of the Gaziantep Organised Industrial District brought Cahit Nakıpoğlu to the top of the industrial district's administration. This victory came against the candidate of the GSO. It was the first time that a candidate other than the one supported by the GSO had been elected. ${ }^{153}$ Akif Ekici presided over the OID between 1999 and 2003. His replacement by the MÜSIAD candidate was the harbinger of the end of the Mayor Celal Doğan's reign in Greater Gaziantep Municipality as Ekici was part of the coalition supporting Doğan. ${ }^{154}$ Thus, an alternative mobilisation has

\footnotetext{
${ }^{152}$ The Nakıpoğlu family owns one of the largest and most important business conglomerations in Gaziantep (including the plastic, packaging materials producer NAKSAN and the textile firm, AKTEKS).

${ }^{153}$ INTERVIEWS WITH AYKUT TUZCU AND ASIM GÜZEL

${ }^{154}$ Ekici has been a good friend of Celal Doğan, both of whom are still leading Gaziantepspor (Gaziantep's successful soccer team playing in the Turkish premiere league).
} 
been on the rise, since the early 2000 s, to the disadvantage of the ruling coalition behind the current corporate regime in Gaziantep.

\section{The direction and dynamics of local agenda creation}

The local corporate regime agenda has been made up of three complementary strategic components: 1) re-scaling the economic field, especially for bigger enterprises, and finding new interlocutors for this purpose, a strategy for whose success the nation state's support has been critical; 2) regulation and control of industrial development, as a response to the increasingly chaotic pattern of production, created by the entry of firms of much smaller scale - and the attempts to contain the impacts of crises which started out at the national (economic crises of 2001) or international scales (the Asian economic crisis of 1998, and Gulf war of 1991); and 3) the need to coordinate and control the emerging plurality of political-economic actors, characterised by religious, economic and political divides, as well as economic ones. These agenda items came to the centre of attention of Gaziantep's key policy-makers especially following the split of the GTSO, and were mainly the concerns of Gaziantep's big industrialists.

Such a comprehensive approach to local policy making inevitably requires a sort of political engagement and scalar strategy beyond simply maintaining good relations with the politicians at the national scale. In fact, lobbying on behalf of the city and the expansion of the portfolio of the interlocutors through scalar strategies of representation required the presentation of the city as a unified and strong actor before all non-local actors. In this regard, the GSO and the GTO have been actively and closely 
colloborating to promote the first component of the agenda. The second has been more of an issue for the GSO. The GTO played a more critical role in pursuing the third agenda item. In the remainder of this chapter, we will look at the last two agendas. The first will be the focus of following chapters.

\section{- Regulation and Control of the Chaotic Pattern of Industrial Development}

Soon after the GSO was established, Kamil Şerbetçi, the then-president of the GSO, declared that the new investments, partially fuelled by the influx of smaller newcomers, posed a threat to the existing stable production by competing against the already producing firms. He also complained that SMEs lacked the financial and organisational skills to find new markets and new sectors, as well as to access technology and R\&D $(1990,26)$. The increasing intra-local competition was perceived as dangerous by the GSO, necessitating a regulatory approach to Gaziantep's industrial development. For this reason, the entrepreneurs of Gaziantep and Southeastern Anatolia were in need of an organisation(s) and institution(s) which would inform and lead these entrepreneurs (Yorum 1990; Şerbetçi 1993; Yalkın 1990).

That plea for an active intervention was directed to the national state. At that time, it was not a statement of the GSO's intention to directly undertake such a role. As noted, the GSO's institutional capacity was insufficiently developed at that time. In fact, when the GSO was first established, it was suggested that the GSO prepare an industrial inventory of Gaziantep and hold a conference on the future of industrialisation in 
Gaziantep. At the time, the suggestion was ignored ${ }^{155}$, but the GSO eventually began to take this problem seriously. The transfer of Nejat Koçer from the GAGİAD's presidency to the GSO marked the turning point.

There were four important policy tools introduced by the GSO to shape the course of the city's industrial development: a) the "trademark city" project; b) the "industrial corridor" project; c) to make the chamber a member of the administrative board of the Organised Industrial district (OID) in $1990^{156}$, which it controlled until the revolt of 2003 (when Cahit Nakıpoğlu was elected as the president of the OID, against the will of GSO's administration); and d) the distribution of state incentives by the GSO, whereby the GSO began to act as the office of assignment of incentives and could set certain priorities.

The specific target of each of these means of intervention has been defined at a different scale. The trademark city project, for example has had implications for both the inner-logic of local development and for the establishment of linkages with the global economic processes. It has been a formula for transforming Gaziantep's industrial production pattern, from an intermediary good producer towards becoming a final product producer. Such a transformation aimed at increasing the profit rates and

\footnotetext{
${ }^{155}$ Aykut Tuzcu stated that when the chamber was first established, he had suggested that GSO prepare an industry inventory for Gaziantep and to bring the investors, state offficials and interested parties together with the businessmen of Gaziantep to set an atmosphere of understanding conducive to a healthy industrial development in Gaziantep. But, this did not happen, partially due to the lack of engagement on the part of the administrative board (INTERVIEW WITH AYKUT TUZCU). I think, beside the presence of certain (political) concerns behind such inertia, another important reason was the lack of professional expertise.

${ }^{156}$ INTERVIEW WITH KÜRŞAT GÖNCÜ.
} 
the quality of the products to improve the city's competitive edge. The cultural and geographical significance of Gaziantep has also been put on the table: Gaziantep itself is defined as a Trademark. Hence, "Made in Gaziantep" is to become a sign of high quality. Recently, this project won the "Best Unconventional Project Award" in the 2005 World Chambers Competition, a competition organised by the World Chambers Federation - WCF - and International Chamber of Commerce - ICC. ${ }^{157}$ I will highlight the implications of this in terms of the re-scaling strategies of Gaziantep's bourgeoisie, later.

The industrial corridor project, which is concerned with the development of a regional scale, is a reflection of GAP's regional master plan. The idea of 'corridor' is based on the vision that the economy of Gaziantep will eventually start to work more closely with the cities on the Mediterranean coast (Mersin and Adana) and the Şanlıurfa/Harran region (The GAP Project Master Plan). According to Ayata, this integration process will lead to the emergence of a Greater Southern Region, a region based on a network of industrial cities. ${ }^{158}$

The project was discussed at the local vision meetings organised by Osmanlı Bankası (a national bank) in Gaziantep, where it was originally introduced as the

\footnotetext{
${ }^{157}$ The competition was a part of the World Chambers Congress which took place in South Africa. The GSO outpaced the projects of the St. Lawrence Chamber of Commerce - USA - (on Global Market Platform for Local Products), the Nepal Confederation of Chambers of Commerce and Industry (on Prevention of Child Labour); and the Auckland Chamber of Commerce (on Introduction of Diversity to the Business World) in the final selection process (www.gso.org.tr News, 23 June 2005).

${ }^{158}$ The international developments in the Middle East, according to Prof. Ayata, can make a remarkable contribution to the emergence of this new network, by turning the region into a centre of economic attraction (INTERVIEW WITH SENCER AYATA).
} 
“Active Industry 2000" project. During the meeting Prof. Kenan Mortan, one of the speakers, suggested that it would be better to call this as an industrial corridor project, in line with the GAP Master Plan (Yorum 5 (37)). The project is still at the formative stage. Yet, it is important to see what sort of a re-orientation might be under way, as it could transform the industrial structure of Gaziantep via establishment of partnerships with the political-economic representatives of other cities and their economies. In other words, the trade-mark city project and the industrial corridor project highlight the establishment of collaboration with other interlocutors (other cities, non-local actors including but not restricted to international and/or supra-national organisations). These projects aim to establish the GSO as the institutional and political link between the "local" and "non-local", thus increasing its significance in local politics.

The other two policy tools, i.e, control over the administration of the Organised Industrial District and the distribution of incentives, could have a direct influence on the form of local industrial development. Here, unlike the preceding two projects, the scale of enterprises targeted by the GSO has been the larger enterprises that make up the constitutency of the GSO. The crucial point about these two policy tools is that they are political in nature. The tensions between the state and the industrialists, and the tensions inside the industrial bourgeoisie, could alter the nature and effectiveness of the policy tools. In other words, they are not neutral policy instruments and procedures, but resources won by negotiation and political means. 
- The need to coordinate and control the emerging plurality

The transformation and diversification of the economic structure of Gaziantep resulted in emergence of a multiplicity of new actors, including the GSO and other business associations. Apparently, this diversifying portfolio of actors taking part in Gaziantep's political-economy has constituted a new challenge for the GTO, as the oldest representative of Gaziantep's bourgeoisie. This, we could argue, pushed the GTO to assume a more active role in coordinating the actions and policy engagements of the other actors. According to the general secretary of the GTO, during the 1990s, the GTO's calls for solidarity and collaboration bore fruit. All public organisations and institutions in Gaziantep began to work together. ${ }^{159}$ Yet, the call for solidarity and establishment of the GTO as the institutional centre of Gaziantep's local policy-making, required another sort of engagement, beyond creating political links between public and non-public representatives of different sections of Gaziantep's local society.

To be able to sustain and improve its credibility, the GTO became more involved in improving the social and cultural infrastructure of Gaziantep. This included; 1) active involvement - sometimes taking the lead - in the establishment of organised industrial districts (as well as small industry estates); 2) establishment of the GAP Exporters Union in Gaziantep; 3) establishment of an electricity distribution company (which has been a public service); 4) attempts to stretch the natural gas pipeline to Gaziantep; and 5) the establishment of a gas-distribution company for the city. The

${ }^{159}$ INTER VIEW WITH MESUT ÖLÇAL. 
GTO's leadership has become important not only in economic terms, but also in social and cultural terms. For example, the GTO played an important role in the establishment of Gaziantep University (GAZÜ) as well as in the opening of departments and vocational schools related to the dominant economic activities of Gaziantep. Activities such as the distribution of educational materials to primary/secondary school students (grades 1-8), the establishment of health centres (especially in industrial centres), the organisation of concerts, of meetings, and the preservation of historical sites, all constitute examples of the GTO's active involvement in Gaziantep's social and cultural life. The GTO moved into a very modern - and quite large - building, designed to serve as the centre of social and cultural activites, in $2003 .{ }^{160}$ Given the scale and the breadth of the projects undertaken by the GTO, it could be said that it stepped in to assume the role of a major actor in Gaziantep's local politics, capable of convincing different local actors to pursue a specific agenda using its credibility. ${ }^{161}$

\section{The role played by other key local actors in Gaziantep's corporate regime}

As noted earlier, the pro-business atmosphere of the 1980s increased the business associations' weight in local civil society and local politics. Suppression of left movements and the denial of rights to unionise and to strike also contributed to this. In

\footnotetext{
${ }^{160}$ INTERVIEW WITH MESUT ÖLÇAL.

161 As noted, at the level of Gaziantep's local bourgeoisie, a similar function of coordination across different fractions of the local bourgeoisie has been informally undertaken by the GAGIAD.
} 
such a context, as the sole official representative of a now legitimate section of society, the local business chambers could constitute one of the few channels of communication between the state and local concerns. Thus, Mr. Ölçal, the general secretary of the GT[S]O since 1984, could claim that the GTO is the elder brother of all civil society organisations in Gaziantep, from time to time helping them to solve their problems by using the GT[S]O's own influence and connections with the extra-local actors and institutions. ${ }^{162}$ Nevertheless, the institutional significance of the GSO and the GTO had to be substantiated with the active cooperation of a number of other key local players so as to consolidate the local corporate regime.

There were three strategic institutions whose cooperation was necessary to establish the local corporate regime: the local government, the representatives of the central government present in the city, and the local media. Of these, the first two mainly served to redistribute public resources to favour a pro-business, pro-industrial local political agenda, and to clear potential obstacles that could stem from the resistance of these actors to the agenda promoted by the GSO and the GTO. The local media's role was to promote and legitimise the political claims of the local bourgeoisie, to introduce new horizons to the local corporate regime and to lobby on behalf of these interests at the non-local scales.

${ }^{162}$ INTERVIEW WITH MESUT ÖLÇAL. 
The role of the local government and urban manager in the formation of the local corporate regime

That the local bourgeoisie had become the key actor in local politics in the 1990s is apparent in the changing composition of the Greater Gaziantep Municipality Council. Bulut's (2000) insightful analysis indicates that there was a shift from a council dominated by educated managers and professionals, coming from the public and state sector with a lower or middle class background, to a council increasingly dominated by rich actors (businessmen and others) albeit with lower levels of education. ${ }^{163}$ Interestingly, this shift parallels the transformation from a rather managerial approach to local governance (local policy making as the responsibility and field of activity of professionals) to the dominance of business interests.

Of course, the composition of the council is still a proxy variable. In the municipality of Greater Gaziantep, the most strategic interlocutor and site of representation is the mayor and the management of the municipality, not the council itself. Bulut's survey indicates that the professional organisations, private clubs and associations, which are relatively powerful institutions operating in a city mainly controlled by the business community, are the groups which face the least difficulty in finding access to the political and administrative core of the Greater Gaziantep Municipality $(2000,47)$. In other words, the survey conducted by Bulut supports our point that the representational strength and the level of access of economically powerful

\footnotetext{
${ }^{163}$ To give the numbers: $70 \%$ of the council members who served during the period from 1989 to 1994 were university graduates. This share decreased to $56 \%$ in the period from 1994 to 1999 ; and declined to $35.3 \%$ in the 1999-2004 period (Bulut 2000, 36-38).
} 
groups has been continuously increasing since 1980 . Yet, the most critical development in the sphere of local government that assured the dominance of business interests in Gaziantep's local politics was the establishment of the Greater Gaziantep Municipality (the metropolitan municipality) in 1989 and the coming to office of a strong entrepreneurial mayor, Celal Doğan. This development was timely for the construction of the local corporate regime, and coincided with the split of the GTSO. An astute observer of Gaziantep's local politics emphasised that Doğan's coming to office marked the watershed in this transformation, whereby the business community's agenda became the centre of local politics, and the weight of Gaziantep's bourgeoisie in local politics became more visible. ${ }^{164}$

As we saw in Chapter 2, the 1980 Coup and the subsequent political-economic transformation in Turkey initiated the re-scaling of the national state. The decentralisation of government and establishment of the two-tiered metropolitan municipalities constituted an important pillar in this transformation. The original idea of undertaking such an institutional re-structuring came from the post-coup transitional government, to control the 'anarchy' created by small municipalities supporting/supported by the leftist groups before 1980 . The squatter areas had played a crucial part in the leftist mobilisation of the pre-1980 era, which directed the attention of the military to these areas. Thus invesment in urban infrastructure gained a strategic significance. The Motherland Party of Özal (ANAP) took this opportunity and passed law \# 3030 - the metropolitan municipality law - in 1984. It is important to remember

\footnotetext{
${ }^{164}$ INTERVIEW WITH ASIM GÜZEL.
} 
here that the ANAP's economic recovery strategy relied upon the promotion of sectors of housing, energy, infrastructure, and urban areas became the target and site of this strategy. This administrative reform was a product of the changing form of state intervention with the national economy, promoting the "urbanisation of capital". 165

The de-centralisation of resources and authority created a rather internallycentralised local government structure with the metropolitan mayor on top. The new municipal system was relatively more professional and had at its disposal more resources (Ersoy 1992). The result was the creation of a stronger mayor, now in control of a more professional and better organised local government. These changes turned the metropolitan mayor into a true urban manager and Doğan fit well in this position for Gaziantep. Local government reform had been recently introduced and there was a need for consolidation. This required a mayor who would be able to make use of the new possibilities to bring local government to the centre of local politics - a task which Doğan undertook when he came to power.

As Harvey ([1989] 2001) notes, such individuals can play an important role in the passage from one regime of accumulation to another at the local scale. This was true for Doğan's municipal practice and his political agenda. As a mayor with a socialist (and activist) background, he could be seen at first glance, as the inheritor of the traditional CHP leftism of Gaziantep. His vigorous engagement with the issues of local political-economy in Gaziantep was reminiscent of the CHP managerialism of the pre-

${ }^{165}$ ANAP as a new party in need of establishing a local support base and party cadre for itself, used the urban infrastructure/development projects to distribute the rents to (and to create) a loyal urban bourgeoisie, and urban amnesty laws and re-development plans to transfer the urban rent created thereby to the inhabitants of the squatter areas (Şengül 2001). 
1980 era. Yet, although he was the candidate of a social democratic party (Sosyal Demokrat Halkçı Parti - the SODEP / the Social Democratic Populist Party), his policy preferences fell within the liberal camp. He stood for an ideological change for Gaziantep. As a top bureaucrat of Doğan's administration observed, the ideological atmosphere of Gaziantep changed, from one dominated by the left ideology to a marketoriented liberal ideology. ${ }^{166}$ Doğan's managerialism contributed to the formation of a corporate regime in Gaziantep in two ways: a) intervention into the urban physical development in Gaziantep, and its consequences for the city's economy; and b) the role he played in the promotion of a pro-business agenda.

Let us start with the former. As we saw earlier, urban regime theories tend to focus exclusively on cooperation between the local business communities and the local government around the issues of land development. The creation and re-distribution of rent generated by urban physical development, as well as urban consumption, comes to the centre of attention both in real urban politics and in the literature devoted to this topic. Given the shift in capital accumulation strategy in Turkey as introduced by Özal's ANAP, one would expect to see it dominate the agenda of the local corporate regime of Gaziantep. Yet, land development issues did not constitute the central agenda of the local corporate regime, partly thanks to the land development policies of the Greater Gaziantep Municipality.

\footnotetext{
${ }^{166}$ INTERVIEW WITH HASAN ÇEVIK.
} 
In fact, the reduced role of the construction sector and urban rent related activities had to do with the Doğan government's planning and housing policies at the local level. The chief of the Greater Gaziantep Municipality Urban Planning Department, Yavuz Selim Ay's (1997) account of the activities undertaken by the municipality highlights the municipality's housing developments, which sought to curb rent based speculations and to control urban development in Gaziantep, especially in the districts of Göllüce, Kızılhisar-Serince, Bağlarbaşı, and Şam Mezrası. The Greater Gaziantep Municipality thus established itself as a powerful actor in determining the form of housing provision. The municipality's strategy has been based on acquiring the land from the central government, preparing the physical development plans and the urban infrastructure, and then selling the land to developers, and especially to housing co-operatives. In addition, the municipality increased the area coverage of the master development plan, thus relieving the pressure on the city centre (Ay 1997, 44-45). ${ }^{167}$ Doğan's interventions were timely as the 1990 s were characterised by domestic and international financial crises that could well have pushed local commercial and industrial capital towards the construction sector. It can be argued that this policy contributed to the primacy of industry as a field of investment by inhibiting the flow of capital to the construction sector.

\footnotetext{
${ }^{167}$ Critics, such as Asım Güzel (the then-president of the chamber of Architects), openly criticises the approach taken to development in Gaziantep on the grounds that the physical development policy was rather pragmatic, and lacked a comprehensive approach. He notes that what was done was simply to increase the area coverage of the original development plan, which was passed in 1977, to three times the original size, without introducing a coherent development vision. Nevertheless, it could be argued that the physical development policy of Doğan helped to lower the prices in the housing market.
} 
Another important intervention was the re-location of almost all the shops and workshops of the esnaf and artisans, originally located in the inner city, to an organised small business centre outside the city. The scale of the project was substantial. The GATEM (Gaziantep Ticaret ve Endüstri Merkezi - the Gaziantep Trade and Industry Centre) built in the Eastern Part of the city brought together different Esnaf groups and professions. The creation of the GATEM can not be understood simply as re-location of the trade/industry functions (which used to be dispersed in different parts of the innercity), but also as the creation of a new, true economic centre, as a catalyst (Ay 1997, 4752). Such a process could not have been accomplished without the full agreement and collaboration between the municipality and the leading cadre of the esnaf and artisan chambers. $^{168}$

As for the second dimension, Doğan's interventions cleared the political obstacles to the local bourgeoisie's coming to the centre of local politics, and played a catalysing role in building the corporate regime during the 1990s. He closely collaborated with the representatives of different fractions of the local bourgeoisie. An important characteristic of this colloboration was that Doğan preferred to work only with big names. In fact, the relations between the local party branch of the CHP and Celal Doğan had been full of tension (see Gaziantep'te Sabah 9 August 2002; 23 July 2003), as Doğan was not responsive to the clientelist demands of the grassroots. He chose to work with a narrower set of people ${ }^{169}$, which created a different style and

${ }^{168}$ INTERVIEW WITH YAVUZ SELIM AY

${ }^{169}$ (INTERVIEW WITH SENCER AYATA) 
image of (local) politician (and politics), as one above parties, distanced from populist demands, always project-oriented, working closely with the powerful names of the city. $^{170}$

Ayata notes that Celal Doğan always had a liberal political agenda and sought to establish broad (local and national) coalitions. ${ }^{171}$ Economic development and solution of economic problems have long been a priority, along with a loosely articulated liberal discourse open to all sections of the society. The local coalition Doğan wanted to promote not only brought the local bourgeoisie's concerns to the centre of attention; he also encouraged individual entrepreneurs to be more actively involved in formal politics. For example, in 1996 , during the celebrations of the $7^{\text {th }}$ anniversary of the establishment of the Gaziantep Chamber of Industry, Doğan touched upon the political instability and urged Gaziantep's industrialists: "If you industrialists had put your

\begin{abstract}
${ }^{170}$ The following account of a verbal exchange between Asım Güzel and Abdülkadir Konukoğlu (the president of the GSO assembly and the owner of the SANKO Holding, the leading business conglomerate of Gaziantep) gives us an idea about the degree of consensus between the leaders of the local corporate regime and Doğan. Güzel, the ex-president of the Gaziantep Chamber of Architects, was a candidate from the left-leaning DSP - of Ecevit- for mayorship of the Greater Gaziantep Municipality in the 1999 elections, when Doğan was also competing for his third term. During the election campaign, Güzel was invited to an open forum broadcast live from a national television channel (NTV). During the forum, he raised the following criticism of the powerful names of Gaziantep: "The present institutional structure does not allow the presentation of all sections of society. There are institutions, other than the GTO [the chamber of commerce] in this city. There are trade unions, other NGOs. There are neighbourhood beautification associations ... We want to change this structure". The response of Konukoğlu was that (according to Güzel): "We are happy with our balance. We work in harmony with our governor, our police chief, our mayor, our chambers of commerce and industry". In fact, the GSO assembly took a decision to support mayor Dogan at the local elections, despite the fact that the party he was a candidate from [the CHP] had lost previous national elections, and that local chambers were not allowed to be officially involved in politics (cf. http://www.dso.org.tr/ekolarsiv/sayi8/dengaz.html).
\end{abstract}

${ }^{171}$ Here, we should also note that the coalition behind Doğan was not only a coalition of powerful institutions. It also relied on the voter's support, cutting across the nationally inspired local political divisions (Bulut 2000). 
weight behind the political parties, today, you would not be condemned to the $5^{\text {th }}$ class politicians" (Yorum 1996, 17). He maintained that he was happy with the entry of business into politics, and personally encouraged this (interview with Doğan in Gaziantep BSB Kültür Dergisi 1997, 110-127). The policy agenda Doğan has defended could and should be seen as an expression and summary of the main political framework on which the corparate regime was built in Gaziantep, especially during the 1990s.

A note of caution is due here. Although Doğan played an important role in facilitating the birth of the local corporate regime, the role of the mayor in the formation of an urban regime, and the production of long-term strategies, is restricted structurally by the fact that the mayor's office is not a permanent post. In fact, Doğan's loss in the 2004 local elections can be seen as a sign of structural change in the political atmosphere of Gaziantep and the transformation of the corporate regime, caused by a re-alignment of the political divisions between different business groups in Gaziantep. ${ }^{172}$ We will elaborate on this in coming chapters.

\section{Governor's office}

In Gaziantep, the institutions established by - and representing the central government constitute an important pillar of the local corporate regime in Gaziantep. In other words, the re-scaling of the state does not only work through institutional decentralisation of

${ }^{172}$ This was caused by a change in the nature of the local bourgeoisie in Gaziantep - once again - as well as the changing political atmosphere in Turkey, which is based upon re-scaling of politics in Turkey especially in the early 2000 s. 
the public administration system. The localisation tendency could well work via active collaboration of the local representatives of the national state with local actors. The governor's office in Gaziantep has been one of the most critical sites in that respect. The governors who served in Gaziantep played an important part in the legitimation of Gaziantep's bourgeoisie's role in local policy-making, while also minimising the potential resistance that could come from the bureaucrats serving under them.

The governor is the highest ranking, appointed civil servant in a province, representing the national state in that locality. The local branches of all ministries serve under the governor, whose responsibility is to assure the coordination of and consistency in the provision of public services. Governors also enjoy the capacity to act as the representative of that province before the state and other official bodies, because they have a second responsibility: acting as the head of the provincial local government, which is formed by an elected assembly. ${ }^{173}$ In this respect, their job has a political dimension. The political nature of the post is further emphasised by the fact that it is not permanent. They are appointed by and could be replaced at the will of the national government. Thus, normally, to consider governors as permanent components of local politics and policy making actors in local politics is not possible. Nevertheless, they actively control institutional and other resources that could facilitate and shape the economic development of a city and the province. This makes theirs a very strategic post.

\footnotetext{
${ }^{173}$ In practice, provincial local governments in Turkey are not effectively functioning. Nevertheless, there are reform attempts to turn them into more engaged territorial governments.
} 
In Gaziantep, the governors have usually been very active in local policy formulation, and have been in close contact with the representatives of the local bourgeoisie. For instance, Muammer Güler, an ex-governor of Gaziantep who was later appointed to serve in İstanbul, took an active part in the formation of the GAGEV, the economic development foundation of Gaziantep. This is also true for the current governor. A businessman interviewed cited Governor Bilgin on his approach to the entrepreneurs: The governor emphasised that if anything happens to the business people in Gaziantep, he would be the first to protect them, and the bureaucrats serving under him could not - and will not be allowed to - do anything to create obstacles in front of the entrepreneurs. ${ }^{174}$ Interestingly, the general secretary of the GSO noted that the bureaucrats who are responsible for services related to the economy and industry would be isolated by the business community if they adopted a negative approach to local entrepreneurs. ${ }^{175}$ In fact, not only the governors but also high-level bureaucrats serving under them are in close contact with the local bourgeoisie.

In cases where the governor adopted a more prudent approach, the local bourgeoisie took a combative stance against the governor. Governor Erhan Tanju, who served between Güler and the current governor, chose to pursue such a policy. He openly declared that everyone had to do their business, and that he could attend the meetings he had to, but had no time for personal (one-to-one) relations (Yorum 2001 (8)). According to Hüseyin Toprak, the editor of the journal Yorum, the governor's

\footnotetext{
${ }^{174}$ INTERVIEW WITH MUHARREM BALAT

${ }^{175}$ INTERVIEW WITH KÜRŞAT GÖNCÜ
} 
approach annoyed certain business people, industrialists, mayors, and certain chambers (even certain directors of the local branches of the bureaucracy), who were used to having a close relationship with the higher echelons of the bureaucracy. ${ }^{176}$ Not surprisingly, Governor Tanju was replaced by the current governor in less than two years. Normally, the governors who develop positive relations with the representatives of the local bourgeoisie tend to stay in their office for longer periods. For example, the governor preceding him had served 6 years. The governor's weight in Gaziantep's political-economy is very much affected by the nature of relations with the business community of Gaziantep.

\section{The local media}

Logan and Molotch (1990) maintain that the media can play a statesman-like role in local politics, as they can identify their position as 'above' particular interests. Their capacity to influence public opinion helps them play an important role in the formation and promotion of local agendas. In the case of Gaziantep, the media sector has experienced a boom in terms of the number of locally published newspapers, journals and TV stations, especially beginning from the late 1990s. The local newspaper Gaziantep'te Sabah - the oldest local newspaper of Gaziantep - and its owner Mr.

\footnotetext{
${ }^{176}$ Hüseyin Toprak's editorial appeared a month after the governor's policy declaration was first published in his journal. Toprak mentions that they started to talk about the Governor behind the closed doors, on the grounds that "he brings in new traditions to the old village" (eski köye yeni adetler getirmek). As, Toprak continues, he did not invite them to drink coffee together nor spent time having coffee with anyone else, other than meeting them when absolutely necessary ... He further points out that this attitude of the governor disturbed those who thought they were the owners of Gaziantep.
} 
Aykut Tuzcu assumed a critical role. The local media contributes to the formation of the local corporate regime in Gaziantep, and to the pursuit of related scalar strategies of representation, in four important ways:

a) As a catalyst in local politics, and particularly in intra-bourgeoisie affairs: Mr. Tuzcu mentioned that as an industrialist (owner of printing industries) and a member, he initiated and organised the official split of GTSO, and thus the birth of GSO a separate chamber of industry. Nevertheless, as we shall see later, GSO did not evolve the way he wished. ${ }^{177}$ Thus, the role he played was more one of a catalyst, and the consequences of his intervention were definitely transformative and long lasting for the politicaleconomy of Gaziantep;

b) Defense of the rights of the local bourgeoisie in general: This happened especially during difficult times. Gaziantep'te Sabah took an active role during the local economic crisis of 2001, supporting the local industrialists against the local branches of the national banks, while fostering a sense of solidarity in public with the local business. The significance of the local media in defense of the local interests, even at the national scale, is also emphasised by the leaders of the corporate regime ${ }^{178}$;

\footnotetext{
177 At least, his suggestions for preparation of an industrial inventory, for example, were not taken into consideration by the administrations of the GSO, who came under the control of big players, wishing to keep the GSO small but under their influence. (INTERVIEW WITH AYKUT TUZCU).

${ }^{178}$ The GTO president (Mehmet Aslan)'s plea for empowering the local media should be underlined, in this respect. In their meeting with the GAP development agency representatives, he cites the incident of harsh punishment of kids who stole baklava from a bakery shop in Gaziantep which was on the national
} 
c) Local (and national) agenda formation: The media lent active support to Turkey's accession to the European Union, and attempts to increase the significance of Gaziantep's economy in this process. A pro-European agenda has been actively promoted by Gaziantep'te Sabah. This did not remain at the level of reporting the issue in the newspaper. Mr. Tuzcu also used his personal contacts towards this purpose;

d) Use of personal contacts to find new interlocutors, and to facilitate the scalar strategies of representation pursued by the corporate regime: The story of the EU information office in Gaziantep, and the establishment of the GAGEV (the Foundation for the Development of Gaziantep) constitute good examples of this facilitative role of the local media people.

\section{Conclusion}

Our discussions so far indicate that the post-1980 national accumulation strategy shift and the associated state re-scaling process paved the way for the emergence of Gaziantep's local entrepreneurialism, which took the form of a local corporate regime. This happened in four ways: a) the national accumulation strategy shift considerably contributed to the transformation of the composition of the local bourgeoisie leading to the birth of a stronger local industrial bourgeoisie, while also promoting a pro-business

news for days, and how this became an embarrassment for Gaziantep, overshadowing the economic success of the city. Aslan claims that they need stronger local media so as to be able to defend their rights (Aslan 2000). 
political atmosphere in both national and local politics, thereby altering the local power balances; b) local business associations started to gain significance as the most strategic site and actor of representation of the interests of the local bourgeoisie, following the rescaling of the sites of representation of the bourgeoisie before the national state; c) rescaling of the forms of internal organisation of the state provided the local bourgeoisie with strong allies in the construction of the local corporate regime; and d) the national accumulation strategy shift and associated changes in the forms of intervention, and the national political and economic instability of the 1990s pushed the local bourgeoisie, and especially the big industrialists, to search for new interlocutors to implement an increasingly multi-scalar local accumulation strategy.

I indicated that the above mentioned dynamics located the local business associations to the centre of local politics and policy-making. For Gaziantep's local bourgeoisie - led by its industrial fraction - to be able channel local resources, energy and attention to a multi-scalar industrialisation strategy, the local business associations themselves had to go through a series of organisational restructuring, beginning with the split of the GTSO. Especially the increasing pressure of the logics of membership and goal formation on the GTSO, and then on the GSO and the GTO, determined the institutional form of the political mobilisation of Gaziantep's bourgeoisie. The institutional reforms that the GSO and the GTO went through, and the establishment of private business associations, helped Gaziantep's local bourgeoisie to improve its capacity to come up with a comprehensive policy agenda, and to create a political consensus around it. As noted, the re-scaling of the internal forms of organisation of the 
national state helped the GSO and the GTO to find strong local allies to establish the local corporate regime. The Mayor of the Greater Gaziantep Municipality, the Governor's office and the local media provided the supportive pillars for the local corporate regime, officially led by the GSO and the GTO.

In this chapter, I have outlined three components of the agenda promoted by Gaziantep's local corporate regime, the most significant one being the re-scaling of the economic field of activity, or the stretching of the local accumulation strategy across different scales. Here, the other agenda items, namely the 'regulation and control of industrial development' and the 'coordination and control the emerging plurality of political-economic actors' have to be seen as concerns that stem from the pursuit of a multi-scalar local accumulation strategy. In other words, re-scaling of the territorial scope of local accumulation and the associated search for new interlocutors pose new challenges to the stability of the local corporate regime, ultimately putting the leadership of the local corporate regime, the GTO and the GSO, to the test. In this respect, for example, the political activation of the local bourgeoisie in general, and the re-scaling strategies pursued in particular, could import the national political tensions they were designed to escape, back into the intra-bourgeoisie affairs at the local scale, as in the case of the MÜSİAD, with a potential to de-stabilise the local corporate regime. In fact, the leading cadre of the GAGIAD and the SANKO Group remain in control of the GSO as the representative of big business interests, as they were reelected during the chamber elections in 2005, after their defeat in OID elections. Nevertheless, the current position of the GSO with respect to the four logics of 
organisation suggests that as the local industrialists came to claim the leadership of Gaziantep's political-economy and the local corporate regime, the GSO, their representative, has internalised the tensions inherent in Gaziantep's local political economy, and the associated challenges to the local corporate regime. 


\section{CHAPTER - V}

\section{"The scalar strategies of representation: Institutional strategies"}

As noted in the theory chapter, local business associations employ institutional rescaling strategies to construct a new local accumulation strategy, a task which involves challenging the balance of power inside the national bourgeoisie, and striving to get the support of the national state in territorial re-scaling strategies. The nerve centres of the integral state constitute the target. Such nerve centres can be seen as "locales" (or politico-institutional arenas) where the national scale is (re)produced and decisions shaping the national political economy are taken. We can produce a categorisation of institutional re-scaling strategies on the basis of the sites of representation. These sites are important not simply because they can distribute the public resources, but could also shape the distribution of surplus value by setting and/or altering the conditions of capitalist accumulation.

The most prominent site is the Prime Minister and the cabinet, whose significance increased especially during the post-1980 era with the centralisation of the economic policy-making and distribution of public resources. Yet, before we concentrate on this institutional locale, we need to discuss the nature of the expectations of the entrepreneurs from the state. An analysis of how the local entrepreneurs see, and what they expect from, the state bureaucracy, constitutes the proper entry-point to 
launch our discussion, because the bureaucracy directly provides the public services and allocates the public benefits. Then, I will examine the role of political parties as a potential channel of representation to the political apex of the state. This section aims to lay out the problems of the conventional forms and channels of representation, which are increasingly emphasised in the context of state re-scaling. Next, I will examine in detail how the attempts to influence the Prime Minister and the Cabinet paid back to Gaziantep's entrepreneurs. I will argue that this is the result of an organised effort that involves, but goes beyond the individual engagement of the MPs and/or ministers from Gaziantep. In the next section, I indicate that this lobbying process required the enhancement and marshalling of the political credibility, and thus the bargaining power, of Gaziantep's local business associations. In this respect, the national business associations provided a fertile ground for this purpose, and Gaziantep's business associations mobilised to capture the leadership of their national umbrella organisations. Thus, their re-scaling strategy not only enhanced their bargaining power but also projected their local concerns to the national scale, giving them a chance to represent their interests as the agenda of the national bourgeoisie.

\section{The state bureaucracy}

According to the representatives of Gaziantep's bourgeoisie, including both large scale entrepreneurs and the esnaf, the construction of more stable, long-term and institutional relations between business and the state will provide a better solution to the problems 
they face, than day-to-day political maneuvers or lobbying. A study conducted by Dilek Eyüboğlu (2000) investigates broader tendencies among the industrialists of four Anatolian Tigers, Gaziantep, Denizli, Kayseri and Çorum, in terms of their views on the state and its bureaucracy. Eyüboğlu makes two important observations: a) entrepreneurs want to have a clear definition of the relations between the state and industrialists; and b) entrepreneurs have contradictory views about the state, based on their interest definition $(2000,65)$. Eyüboğlu's findings indicate that there is no essentialism in the local bourgeoisies' approach to the state. Theirs is a rather pragmatic approach, contrary to the beliefs of the neoliberal politicians and policy-makers. As Eyüboğlu observes, to have clearly defined criteria for state allocation of resources, and to have a specialised interlocutor is preferred over a cloudy negotiation scheme like that of Özal's. The latter provoked the active political engagement of the bourgeoisie.

Eyüboğlu lists industrialists' demands from the state, and indicates that they place greatest emphasis emphasis on the state's guiding role. In particular, they expect the state institutions, such as the State Planning Organisation, to be in close contact with them (2000, 75-77). This guiding function has four important components: 1) broadening the vision of the industrialists, by helping them to find new markets and to enhance their access to new technologies (needed in production and organisation of the production process); 2) provision of a general atmosphere of economic stability; 3) introduction of clearly defined 'technical' criteria in the distribution of state-oriented benefits and specialised agencies for specific sectors. The industrialists are clear about their dislike of 'injustices' in the distribution of credits and the intervention of the 
politicians with the bureaucrats $(2000,70-73) .{ }^{179}$ The fourth dimension involves the introduction of new state regulation to control entry of new firms into the sectors. ${ }^{180} \mathrm{In}$ my case study, the dimension that was emphasised most frequently was the necessity to establish specialised state institutions on a sectoral basis. This demand was voiced by a number of business people and chamber presidents from different sectors and scales. ${ }^{181}$ Hence, it could be argued that (all fractions of) the bourgeoisie in Gaziantep seek further rationalisation and specialisation of the state bureaucracy, which would allow the representation of their problems inside the state bureaucracy. Beyond the need for specialised interlocutors, the competency of existing state agencies is a problematic issue, too. ${ }^{182}$

The lack of such specialised agencies seems to have created a fuzzy road-map for the representatives of the bourgeoisie, especially when they sought the help of the bureaucracy in solving particular problems. This uncertainty created further pressure on

${ }^{179}$ Especially of interest to us is the following part of the quote in Eyüboğlu's study, from an industrialist from Kayseri: "if the state is to give a credit to help it should do it directly ... [and] abolish the intermediaries. ... There are intermediaries in the system. As long as the politician and the administrator go side by side like that, this affair will not be resolved." (Translated by the author).

${ }^{180}$ INTERVIEW WITH YALCIN KONUKOĞLU.

${ }^{181}$ For example, according to Burnukara there is a need for a specialised ministry for the textile sector, which has been the leading sector of industry in Turkey (INTERVIEW WITH ALI BURNUKARA). The same point was also made by the representatives of the Esnaf and Artisans who complained that they need to know where to go when they face a problem (INTERVIEW WITH MAHMUT YILDIRIM - the president of the Artisan Chamber of Knitters/Knitting). Vakkas Katrll (the vice-president of the GESOB) insisted that there was a need for a Ministry of Esnaf (INTERVIEW WITH VAKKAS KATIRLI).

${ }^{182}$ MUSTAFA EKINCI - Group Interview - In my opinion, the GSO and the GTO's active search for new sources of technology and knowledge transfer, including the EU, can be understood in that regard. And the signing of an agreement between the GTO, the GSO, the OSB, the provincial governor and Gaziantep University about establishment of a technopark in Gaziantep can be seen as the most recent instance of this strategy (http://www.sirinnar.net/hab/mayis/23 05/230503.html). 
the representatives of the local bourgeoisie to seek ways to reach the political apex of the bureaucracy - the Prime Minister and the cabinet - where the problems could be solved bypassing the bureaucratic restrictions, or new bureaucratic and legal measures could be introduced. Thus, it could be argued that the institutional re-scaling strategies pursued by the corporate regime leaders of Gaziantep are also a consequence of the problems of representation they face when they interact with the bureaucratic apparatus of the state.

Of course, creation of such specialised agencies is not enough to solve the problems. The definition of who are agency's clients is also crucial, as it indicates that the state formally recognises a certain type of entrepreneur or sector as its focus of intervention and its partner. When this is not done, the specialised institutions created for that purpose could well end up serving another set of actors. An interesting instance of this is the changing profile of the firms from Gaziantep that applied for and received KOBİ incentives. ${ }^{183}$ The total amount of KOBİ incentives given to Gaziantep firms continued to increase after 1998, despite the sharp fall in the amount and number of export/investment incentives with the end of the Yilmaz government. ${ }^{184}$ The size of incentive per certificate also continued to rise as the firms which received KOBI incentives were increasingly applying for larger amounts.

This indicates that there was a change in the incentive strategy of larger firms in Gaziantep. When the political situation changed, the entrepreneurs chose to change their

\footnotetext{
${ }^{183}$ See Charts 3.5 and 3.6 (Chapter 3) where the pattern of KOBİ incentives received is analysed.

${ }^{184}$ KOBİ incentives came to a halt inevitably with the 2001 economic crisis.
} 
locus of engagement with the state, turning their attention from the Undersecretariat of Treasury (working under the Prime Minister) to the KOSGEB, where a less politically selective scheme was adopted in the distribution of 'KOBI' incentives. The KOSGEB is a relatively autonomous agency created for that purpose, whose board of directors include 33 members including different ministers and presidents of various related civil/professional organisations (Gücelioğlu 1994, 42-54). In this context, the influence of direct political intervention for individual incentives was reduced. Here, of course, the vagueness of the definition of 'SMEs' worked to the advantage of large scale capital, thus leading to allocation of scarce financial sources to a relatively more influential and active faction of bourgeoisie.

The analysis portrays a paradoxical situation: clarity of rules and the creation of specialised agencies inside the bureaucracy emerge as a desirable outcome for a section of bourgeoisie, especially those who are vulnerable to crises. Yet, the lack of clarity of definitions can also be beneficial to another section of bourgeoisie who can seize upon the opportunities created by the hazy nature of benefit schemes. Those two different preferences are built upon different and sometimes conflicting strategies of representation. While the former aims at transforming the institutional structure and logic of the bureaucracy to secure long term benefits and attention of the state, the latter works through political influence at the institutional level of the Prime Minister and the cabinet. Ironically, the project of transforming the institutional articulation of the state could not be realised without the political engagement of the bourgeoisie. I argue that 
the presence of these two contradictory strategies led Eyüboğlu to conclude that the entrepreneurs have conflicting views of the state, and their demands are pragmatic.

At this point, it is important to remember Jessop's insights on the forms of representation. Of particular interest to us is his argument that parliamentarism constitutes a superior form of representation as it separates policy-making from implementation, thereby isolating the service provision from short-term, daily political strife. Yet, our discussion so far indicates that this has not been the case in Turkey. The preference for clientelism as the form of representation by the governments during the 1980s was an important factor behind the vagueness of the criteria that informed bureaucratic implementation of services that targeted industrialists. Later attempts to introduce specialised government agencies like the KOSGEB (established in 1990) did not completely solve this problem. The re-scaling of the powers of policy-making to the Prime Minister and the cabinet rendered the use of parliamentarism ineffective, especially the use of political parties as channels of representation. Ironically, the centralisation of decision-making powers required the presence of a stable or single party government so that this policy-making capacity could become operational. Yet, the coalition governments of the 1990s posed a great obstacle in this regard and contributed to the unclear nature of the bargaining schemes. In this regard, the need for organised representation, and the need to develop scalar strategies of representation, emerged as critical necessities for Gaziantep's industrialists and its corporate regime. 


\section{Political parties}

One of the oft-repeated observations of interviewees about Gaziantep's politicaleconomy is that in many ways Gaziantep is a smaller model of Turkey. The political stance of Gaziantep is no exception, according to this common view. The voting behaviour of Gaziantep has paralleled the national trends. According to Çarkoğlu and Avc1, who surveyed the history of regional voting patterns in the country, the parties which came to power at national elections received the same level of vote and support in a number of provinces including Gaziantep $(2002,128-129) .{ }^{185}$ What is striking about the provinces in this cluster is that they are not located in one region, but rather dispersed across the country. Thus, it could be argued that the voting behaviour of such provinces follow a path different from the regions in which they are actually located. This suggests that in addition to the regional contextual factors, national politics and nationally-waged struggles have been more intertwined with local politics, compared to provinces in the other clusters.

Of course, voting is just a proxy variable with a number of analytical restrictions. It does not tell us who votes for a certain party or why, or how, local actors and issues are articulated with national politics, or what the role of political parties is in the establishment of those links. These questions constitute the focus of the following pages. In particular, I would like to look at the questions of; a) whether the local

\footnotetext{
${ }^{185}$ According to the authors, this cluster included Gaziantep, Ankara, İstanbul, Adana, İçel, Hatay, Sivas, Trabzon, Tokat, Ordu, Amasya, Kars, and Sakarya.
} 
representatives of national political parties (including the local branches of those parties and the MPs) play a significant role in local politics; and b) how has the relationship between the bourgeoisie of Gaziantep and the political parties has evolved?

As we saw in Chapter 2, the 1970s was a period when the intra-bourgeoisie struggles were intertwined with the partisan struggle at the national scale, and this was no less true for Gaziantep. ${ }^{186}$ The 1980 Coup marked a turning point in the relations between the bourgeoisie and party politics, creating a distance between the business assocations and the national political parties. Despite the fact that the 1980 s were characterised by a pro-business political atmosphere, and that important figures from Gaziantep contributed to the establishment of the ANAP, Özal's clientelism would not allow the construction of an organised political connection between Gaziantep's bourgeoisie and the ANAP. The distance between the local bourgeoisie and party politics further increased during the 1990s. The crisis-laden economic atmosphere and the part played by coalition governments in paralysing the economic policies was an important reason. Partisan politics completely lost its credibility and attractiveness as a channel of representation for the local bourgeoisie. Politicians were harshly criticised by the leaders of Gaziantep's business associations. In such a context, for example, it is not surprising to see that Celal Doğan, who identified himself as a project-oriented, pro-

${ }^{186}$ The records of the GTSO indicate that the mayor of Gaziantep municipality from the CHP was appointed as the president of the GTSO when the CHP came to power in 1978, following the decree of the Ministry of Commerce, (decree \# 17794, signed on 12.4.1978) and the official order of the provincial governor. The mayor (and his cadre) acted as the president during the CHP rule and was immediately replaced by the old administration in two days after the 6th Süleyman Demirel government came to power, with another decree of the Ministry of Commerce (decree \# 610.2/39, signed on 14.11.1979) (Pekdogan 1999, 47). Apparently, the local business associations were not immune from the fight between the national political parties. 
growth mayor above all parties, became very popular in Gaziantep during the 1990s. As we saw, according to Doğan, the political problems of the country had, in part, to do with the fact that industrialists and traders were not willing to take an active role in politics.

Another important factor that prevented the local business people from taking an active part in political parties was the dynamics of intra-party politics. The delegate system played a critical role in determination of the power structure inside the local branches. The leaders of the local party branches are elected by designated delegates, who were earlier elected by the party membership. To be influential inside the local party organisations, what matters most is how many party delegates support the candidate. In such a context, local-branch politics is permeated by clientelistic relations. This process makes the intra-party election process very conflictual and renders local party organisations quite difficult to control by non-party members. This was the case with the elections in local branches of the CHP in Gaziantep (especially in election of Yasar Ağyüz as the president of Gaziantep provincial branch of the CHP) (see Gaziantep'te Sabah 23 July 2003 - "pearl of the day”, editorial). Moreover, sometimes party headquarters intervene in the elections of their local branches to suppress intraparty competition, as in the case of the AKP. Such interventions could make things worse in terms of the representation of the local bourgeoisie, as certain MP candidates for Gaziantep could be chosen from outside Gaziantep. Ramazan Toprak, a local political columnist cites the case of Kürşat Tüzmen, the minister of the current government responsible for foreign trade. Although Tüzmen is not from Gaziantep, he 
was elected as an MP from Gaziantep, and is in a position to take critical decisions about Gaziantep, while not being aware of the "local balances" (Oluşum 31 July 2003).

Nevertheless, the GTO and the GSO have always had good contacts with the local MPs ${ }^{187}$, and, with few exceptions, almost all MPs have been willing to keep in touch with the GTO and the GSO. ${ }^{188}$ Apparently, beyond being in close contact with MPs, the leaders of Gaziantep's bourgeoisie felt they could dictate their priorities. The best instance of this was the general meeting of the representatives of the GTO and the GSO with the "first rank MP candidates of all political parties", i.e those with the highest chance of being elected at the national elections of November 3, 2002 (see Gaziantep'te Sabah 28 October 2002). The then-president of the GTO assembly ${ }^{189}$ reported that at that meeting they - leaders of the GTO and the GSO - explicitly put their priorities on the table and openly declared that "the MPs would find no political support unless they take the concerns of the business community into account". ${ }^{190}$ The local MPs were expected to cooperate despite their party differences, especially when the issues pertaining to Gaziantep were brought to the parliament. Two factors contributed to this increased bargaining power of the local bourgeoisie in their relations with local MPs: a) enhanced relations between the representatives of the local bourgeoisie and the Prime Minister and the cabinet, which gave them a chance to

\footnotetext{
${ }^{187}$ inviting them to their meetings, sending them reports about the problems of local entrepreneurs and economy.

${ }^{188}$ INTERVIEW WITH MESUT ÖLÇAL.

${ }^{189}$ MUSTAFA GEYLANI.

${ }^{190}$ INTERVIEW WITH MUSTAFA GEYLANI.
} 
bypass the individual MPs as intermediaries; and b) the enhanced political credibility of the business leaders in the eye of the local public, and thus their capacity to shape local public opinion during local and national elections.

The early 2000 s bore the signs of a change in the logic of the relations between the local bourgeoisie and the national political parties, especially with the coming to power of the AKP. Now, for the first time in Gaziantep, the AKP brought an industrialist, Ökkeş Eruslu to the presidency of its local branch. ${ }^{191}$ The recent mobilisation of the MÜSİAD as a business association close to the AKP is another important sign in this respect. It could be argued that the practical boundaries between local politics in Gaziantep and national politics is slowly blurring and intra-bourgeoisie struggles are about to enter the arena of party politics, once again. Yet, this time the situation is different. The AKP is not rivalled by a political party with ties to another faction of the bourgeoisie. If there is to emerge a clash, it could be between a fraction of the bourgeoisie using party politics and national/hierarchical ties as a channel of representation, on the one hand, and a faction which is now less dependent on the party politics, on the other. This distinction could be read as a product of the differentiation inside the local industrial bourgeoisie: between those who gained a momentum benefiting from state incentives/subsidies during the 1980s and the 1990s, and those who could not make it thus far, or just joined the industrial sector with the second wave of industrialisation. ${ }^{192}$ In this potential struggle, the latter comprise those members of

\footnotetext{
${ }^{191}$ INTERVIEW WITH AYKUT TUZCU.
} 
the local industrial bourgeoisie who have directly benefited from the local corporate regime arrangements, which brought them increased spatial mobility, a capacity to rescale both territorially and institutionally, and an increased portfolio of interlocutors, ultimately enhancing their legitemacy in the eyes of (and increased bargaining power vis a vis) the national governments. In other words, we can talk about a struggle between two groups that have recourse to different forms of representation: one sticking with a rather conventional form of representation, namely parliamentarism; the other following a novel form of representation, namely scalar strategies of representation.

\section{The Prime Minister and the cabinet}

As noted, the centralisation of decision-making in economic policies increased the strategic significance of the political apex of the state for the implementation and maintenance of Gaziantep's local accumulation strategy. In particular, the incentives and benefits provided by the Undersecretariat of Treasury and Foreign Trade (later split into two) were crucial for Gaziantep's industrialists who aimed to expand the focus of local accumulation to international markets since the early 1990s. The undersecretariat(s) was under direct supervision of the Prime Minister. Thus, the road to state benefits passed through the office of the Prime Minister. In addition, due to their

192 including - but not restricted to - immigrant capital owners from the Eastern provinces. Of course, the AKP's electoral success in Gaziantep cannot simply be attributed to the support of a faction of industrial capital. The increasing level of poverty, and unemployment fostered by the regional in-migration and the crisis ridden political atmosphere of pre-2002 era have been influential factors in the AKP's success in Gaziantep. 
position as members of the cabinet, ministers also occupied a strategic position in gaining direct access to the Prime Minister.

According to an observer, Gaziantep has always made its political weight felt at the level of national government, because in almost every cabinet there was an MP from Gaziantep who served as minister. ${ }^{193}$ In fact, this observation is especially true for the post-1980 era. Quite a few MPs and local politicians from Gaziantep have been at the forefront of national political debates since the 1980s, and have played key roles in intra-party politics. Gaziantep's industrialists have effectively used these political connections to get access to state benefits during the 1990s.

A caveat has to be made, though. It can be argued that certain economic factors had considerable impact on the allocation pattern of state incentives. These factors include the economic crises that struck the Turkish economy during the 1990s and early 2000s, and the associated government measures to respond to these crises. The rapid industrialisation process of Gaziantep, characterised by a growing base of exporting industrialists, was also a significant factor. Although such factors may have influenced the allocation pattern, the following table (Table 5.1) indicates that it is difficult to establish a strong correlation between the economic performance of Gaziantep and the changes in the number of incentives received by Gaziantep's industrialists.

${ }^{193}$ INTERVIEW WITH KÜRŞAT GÖNCÜ. 
Table 5.1: Gaziantep's export and the export incentive certificates received by Gaziantep

\begin{tabular}{|c|c|c|c|c|c|c|c|}
\hline & 1996 & 1997 & 1998 & 1999 & 2000 & 2001 & 2002 \\
\hline $\begin{array}{l}\text { Number of exporting firms } \\
\text { based in Gaziantep }\end{array}$ & $\begin{array}{l}353 \\
\end{array}$ & 423 & 457 & 467 & 475 & 545 & 585 \\
\hline $\begin{array}{l}\text { Number of exporting firms in } \\
\text { Turkey }\end{array}$ & 23.581 & 23.281 & 24.139 & 24.833 & 25.031 & 28.909 & 31.719 \\
\hline $\begin{array}{l}\text { Turkey's export performance } \\
\text { (in million dollars) }\end{array}$ & 23.224 & 26.261 & 26.974 & 26.587 & 27.775 & 31.334 & 36.059 \\
\hline $\begin{array}{l}\text { Gaziantep's export } \\
\text { performance (in million } \\
\text { dollars) }\end{array}$ & 225 & 393 & 443 & 413 & 435 & 599 & 614 \\
\hline $\begin{array}{l}\text { Number of export incentive } \\
\text { certificates received by } \\
\text { Gaziantep }\end{array}$ & 109 & 262 & 257 & 209 & 181 & 171 & 95 \\
\hline
\end{tabular}

\section{Source:}

- Printed data received from the Undersecretariat of Foreign Commerce (the directorate of incentives implementation-the branch of monitoring);

- $\quad$ http://www.dtm.gov.tr/ead/ekolar1/eko17.xls (export figures by provinces - from the general undersecretariat of foreign commerce).

For example, although the number of exporting firms increased around $20 \%$ between 1996 and 1997, the number of export incentive certificates received by Gaziantep-based entrepreneurs more than doubled in the same period. While the number of exporting firms from Gaziantep slightly increased between 1997 and 2000, from 1999 onwards, the number of export incentive certificates allocated to Gaziantep decreased on a continuous basis. In fact, changes in the number of export incentives allocated to 
Gaziantep-based firms cannot be attributed a general tendency in the export performance of the country, such as dramatic ups of downs in the volume of exports, or the ability of firms to contribute to export, that would compel the government to radically revise its incentive allocation policy, or the usefulness of the incentive policy in general.

There were also political dynamics at work in the allocation of state incentives to Gaziantep's industrialists. In particular, certain ups and downs in this allocation pattern coincide with some of the cabinet changes rather than economic crises and/or the broader industrialisation tendency of Gaziantep. To see to what extent the presence of Gaziantep MPs in the cabinets might have influenced the allocation of state incentives to Gaziantep's industrialists, I constructed Table 5.2. The period from 1992 to 1999 is significant in this respect. Although the incentive schemes were products of Özal's strategy to support an export-oriented economic regime, allocation of these incentives to Gaziantep's industrialists took a remarkable turn with the end of the ANAP rule, and the subsequent establishment of the DYP-SHP coalition. ${ }^{194}$ In the coalition government, initially three Gaziantep MPs - two from the SHP and one from the DYP, an ex-president of the GTSO - became ministers in a cabinet that had 36 ministerial posts.

\footnotetext{
${ }^{194}$ This was the first coalition government of the post-1980 era. The True Path Party (Doğru Yol Partisi DYP) of Demirel as the heir of the pre-1980 AP and the SHP (Social Democratic Populist Party - SHP) as the heir of the pre-1980 CHP were partners in this coalition.
} 
Table 5.2: Changes in the government and the allocation pattern of state incentives to Gaziantep based firms ${ }^{195}$

\begin{tabular}{|c|c|}
\hline $\begin{array}{l}\text { Governments and the number of ministers from } \\
\text { Gaziantep who served in the cabinet }\end{array}$ & $\begin{array}{l}\text { Number of export and investment } \\
\text { certificates received by Gaziantep's } \\
\text { industrialists (see Table) }\end{array}$ \\
\hline ANAP government led by Özal (1) : 1984 & 34 \\
\hline ANAP government led by Özal (1): 1985 & 81 \\
\hline ANAP government led by Özal (1): 1986 & 88 \\
\hline \multirow[t]{2}{*}{ ANAP government led by Özal (1): 1987} & 81 \\
\hline & (approx. 70 per year) 284 \\
\hline ANAP government led by Özal (1) : 1988 & 59 \\
\hline \multirow[t]{2}{*}{ ANAP government led by Özal (1): 1989} & 98 \\
\hline & (approx. 70 per year) 157 \\
\hline \multirow{3}{*}{$\begin{array}{l}\text { ANAP government led by Akbulut (1): } 1990 \\
\text { ANAP governments led by Akbulut (1), then Yilmaz (1) } \\
: 1991\end{array}$} & 55 \\
\hline & 54 \\
\hline & 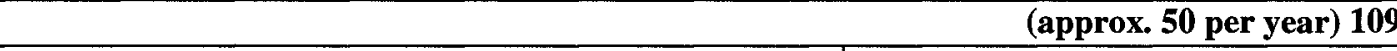 \\
\hline DYP - SHP coalition led by Demirel (3) : 1992 & 72 \\
\hline $\begin{array}{l}\text { DYP - SHP coalition led by Demirel (3), then Çiller } \\
\text { (substitutes Demirel as the head of DYP, coalition with } \\
\text { SHP renewed) (5):1993 }\end{array}$ & 150 \\
\hline DYP - SHP coalition led by Çiller (5) : 1994 & 164 \\
\hline \multirow[t]{2}{*}{ DYP - SHP coalition led by Çiller (5) : 1995} & 418 \\
\hline & (approx. 200 per year) 804 \\
\hline $\begin{array}{l}\text { Unstable (coalition) governments } \\
\text { DYP minority government led by Çiller (2), then DYP- } \\
\text { ANAP coalition led by Y1lmaz (1), then RP-DYP } \\
\text { coalition led by Erbakan starts }(0): 1996\end{array}$ & 270 \\
\hline & 270 \\
\hline $\begin{array}{l}\text { Coalition led by Yilmaz takes over (ANAP, DSP, DTP, } \\
\text { also supported by independent MPs) (3):1997 }\end{array}$ & 438 \\
\hline \multirow[t]{2}{*}{ Coalition led by Yilmaz (3): 1998} & 389 \\
\hline & (approx. 400 per year) 827 \\
\hline $\begin{array}{l}\text { Minority government by Ecevit until mid-'99 (1), then } \\
\text { Ecevit led coalition (DSP, MHP, ANAP) (3) : } 1999\end{array}$ & 259 \\
\hline Coalition led by Ecevit (3) $: 2000$ & 257 \\
\hline Coalition led by Ecevit (3) : 2001 & 228 \\
\hline Coalition led by Ecevit (3): 2002 & 174 \\
\hline
\end{tabular}

195 Source: http://www.basbakanlik.gov.tr/sour.ce/index.asp?wpg=hukumetler; Printed data received from the Undersecretariat of Foreign Commerce (the directorate of incentives implementation-the branch of monitoring). 
When the coalition was renewed due to the leadership change in the DYP, this number increased to five - with three MPs from the SHP and two MPs from the DYP. Gaziantep's substantial weight in the cabinet quickly paid dividends. During the first year of the coalition's rule, the total number of incentives received by Gaziantep's industrialists more than doubled. In 1995, the last year of the coalition, the incentive certificates allocated to Gaziantep reached a level six times higher than the number of certificates received by Gaziantep's industrialists during the first year of the coalition.

1996 was characterised by an unstable political atmosphere. The DYP's failed minority government and the short lived ANAP - DYP coalition were followed by a coalition between the DYP and Erbakan's RP (Welfare Party - Refah Partisi). The Erbakan government had no Gaziantep MP serving as a minister. The coalition stayed in power between mid-1996 and mid-1997. This coalition had to step down in the face of the military memorandum of February 28, 1997 and the increasing public opposition to the Islamist tone of Erbakan's discourse. The threat of a coup d'état, and the extraordinary government measures taken to deal with the economic instability inherited from previous governments, ultimately destabilised the working conditions of the Erbakan government. This instability and the lack of political access to the cabinet and the Prime Minister had a reverse impact on Gaziantep's industrialists' ability to receive incentives during the rule of this government. In fact, the total number of incentive certificates received by Gaziantep's industrialists, especially export incentives (see Chart 3.3), fell sharply in 1996. 
Following the collapse of the Çiller-Erbakan government in 1997, another coalition government was formed under the leadership of Mesut Y1lmaz, the then-leader of the Motherland Party, where - unlike the preceding cabinet - Gaziantep was strongly represented. The new cabinet had 37 ministerial posts, 3 of which were given to the MPs from Gaziantep (Yorum 1(12), 6-7). Gaziantep's industrialists were quick to translate their political influence into a striking jump from around 270 incentive certificates in 1996 to 438 certificates in 1997 . This allocation pattern was marked by another significant turn with the coming to power of the Ecevit governments (first as a minority government, then as a coalition with the national elections in 1999). The number of incentive certificates allocated to Gaziantep dropped drastically during the Ecevit period, despite the fact that there were three Gaziantep MPs serving as minister. This change can be explained by Ecevit's approach to the establishment of informal ties with the business world, which choked the informal channels of representation for Gaziantep's bourgeoisie.

Gaziantep's weight in the cabinet found was also translated to the state investments that directly target the province of Gaziantep in general, as well as the state incentives allocated to individual entrepreneurs. Chart 5.1 indicates that there was a rather systematic effort to channel the state resources to Gaziantep, especially between 1997 and 2002. 


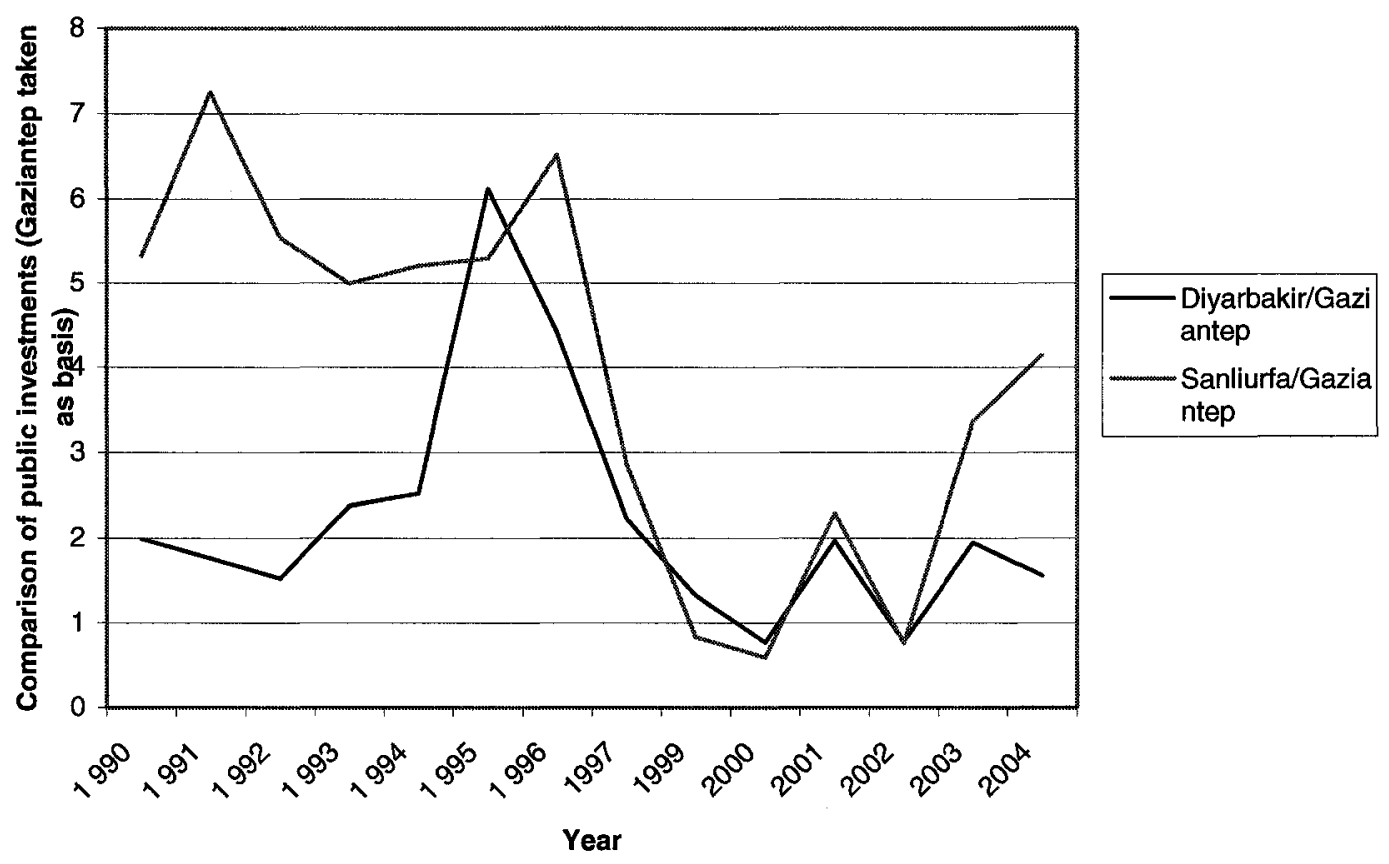

\section{Source $^{196}$ :}

- the State Planning Organisation's website for these values (1999-2004)

- http://www.dpt.gov.tr/kamuyat/il; See Paksoy $(2002,32)$ for the pre-1997 values.

As noted, in 1997, the Ylmaz-led coalition with three Gaziantep oriented ministers came to power. Although Gaziantep's weight in the Ecevit government did not have a positive influence on the allocation of individual incentives, the presence of Gazianteporiented ministers certainly had a positive impact in terms of direct state investments.

196 The calculations were made by the author benefiting from the data provided by these sources. 
In fact, Diyarbakır and Şanlıurfa are the provinces that normally get the lion's share in state investments in the region, mainly due to the huge GAP-related investments. The region's poverty and the Kurdish movement caused the state to pay extra attention to the question of public investments in these provinces. The chart shows that the amount of state investment received by Gaziantep progressively increased in comparison to the amount received by both Diyarbakır and Şanlıurfa, during this period, even surpassing the amount these provinces got in 1999 and 2000.

Although the presence of Gaziantep MPs in the cabinet made a difference in terms of the state benefits Gaziantep received, this influence can not simply be attributed to the individual favour of the Gaziantep-oriented ministers who acted as the benefactors of otherwise weak industrialists and business people of Gaziantep. As the preceding section indicated, especially since the 1990s, Gaziantep's bourgeoisie has enjoyed a stronger hand in their dealings with the local MPs. The following comments from the then-assembly president of the GTO regarding their relations with the current Prime Minister, Recep Tayyip Erdoğan of the AKP, are telling in this regard:

In the last 10 years chambers broke their shells. Administrators and the state are convinced that these institutions are necessary... Now they want to meet the people who are leading the business. The chamber presidents used to be ranked $45^{\text {th }}$ on the official ceremony list. ... But, yesterday we met the prime minister at the airport. We had the breakfast together. We explained our problems ... It used to be the same with the previous governments too. All doors are open to us now. The MPs are asking us to arrange appointments with the Prime Minister, on their behalf. Now chambers have become more influential than the ministers. ${ }^{197}$

\footnotetext{
${ }^{197}$ INTERVIEW WITH MUSTAFA GEYLANI.
} 
This account suggests that the chambers have unfettered access to the Prime Minister's office. It also indicates that leaders of the business associations could intervene with the relations between the Prime Minister and/or ministers, and the local branches of their own political party. This is not simply an increased general significance attached to the bourgeoisie in general, but extra attention paid to the Anatolian bourgeoisie in particular. ${ }^{198}$ Hence, we can conveniently argue that Gaziantep's success in capturing state benefits came as a result of a coordinated effort between the corporate regime leaders and the Gaziantep-oriented ministers.

Of course, increased access to the Prime Minister's office does not necessarily mean that all demands of the leaders of Gaziantep's bourgeoisie are met by the Prime Minister or the cabinet. The most recent instance of this is the exclusion of Gaziantep from the last KÖY program introduced by the AKP government, despite the fact that Gaziantep was on the draft list. In fact, this move by the AKP government spurred some changes in the representation strategy of the local industrial bourgeoisie, with potentially disruptive consequences for the local corporate regime. An important meeting was held in Gaziantep following the announcement of the new KÖY list (http://www.sirinnar.net/2005hab/subat/19 02/19 06.htm). All speakers at the meeting,

\footnotetext{
${ }^{198}$ Again, this attention is not distributed evenly as long as we are concerned with different fractions of the local bourgeoisie. The president of the chamber of knitters/knitting artisans related a story about himself and a number of people representing the Esnaf and artisan community of Gaziantep visiting a minister in 2000. The minister, according to Ylldırım, encouraged them, affirming that he would help to solve their problem, and sent the visiting chambers' representatives to the general director of a bank [Halkbank] responsible for Credits. Yet, it turns out, there was no money dedicated to reduce interest rates on the 'esnaf credits' given by that bank (INTERVIEW WITH MAHMUT YILDIRIM - Group Interview; the same story was repeated by the president of another artisan chamber, Enver Doğan, during a separate interview: INTERVIEW WITH ENVER DOĞAN.
} 
including the presidents of the GTO, the GSO, and the GAGIAD, emphasised the necessity to restructure the incentive programs on a sectoral, rather than on a provincial (read territorial) basis. Here, the reaction of the local corporate regime leaders to the recent KÖY list gives us a clue about the limits of the local solidarity discourse invented to sustain the local corporate regime. Difficulties encountered in receiving territorially-framed state support compel the dominant groups inside the GSO, the GTO and the GAGIAD to seek new institutional strategies that have the potential to reduce the significance of the local corporate regime as a territorial form and vehicle of representation. Apparently, unlike a territorially-defined incentive scheme that would be equally accessible to all local entrepreneurs, a sector-based scheme would offer benefits that are provided on a selective basis.

\section{The umbrella organisations}

The enhanced political credibility of the corporate regime leaders of Gaziantep in their dealings with the apex of the state can not simply be explained by the increasing political signifance of the bourgeoisie in general, and the associated pro-business approach of the politicians in general. The corporate regime leaders of Gaziantep had to work hard to establish Gaziantep's cause as a national one, to turn themselves into nationally recognised figures, and to seek alternative channels of representation that would facilitate direct access to the political apex of the state. This necessity was 
emphasised especially with the problems met in using parliamentarism and clientelism as channels of representation to the Prime Minister and the cabinet.

In this regard, the local corporate regime's institutional re-scaling strategy involved an active effort to capture the control of the national umbrella business organisations. For example, the re-gained political credibility of the TOBB from the 1990s onwards, this time as the representative of the Anatolian bourgeoisie ${ }^{199}$, turned it into a strategic site and channel of representation ${ }^{200}$ for Gaziantep's corporate regime. In addition, Gaziantep's business leaders also stretched the focus of this re-scaling strategy to the newly established umbrella organisations, like the TÜGİK (Türkiye Genç İşadamları Konfederasyonu - The Confederation of Young Businessmen of Turkey), where the İstanbul-based bourgeoisie has been influential.

As we saw earlier, the strategy report produced by the GTZ for the GSO suggested that it follow an active strategy of alliance-making to reach its targets and to establish good relations with other (governmental and non-governmental) actors, including the fellow chambers of industry to promote the interests of the GSO, and of Gaziantep in general. We see that the leading cadre of the GSO has been actively

199 The current president of the TOBB, Rıfat Hisarciklığlu, is an 'industrialist' from Ankara and advences an openly pro-Anatolian discourse.

200 INTERVIEW WITH MUSTAFA GEYLANI. An important instance of this political weight was Yalım Erez's entry into party politics, after he left his presidency of TOBB in 1995: "Yalım Erez was one of the architects of the Motherland-TruePath (ANAYOL) Party, Welfare-True Path Party (REFAHYOL) and Motherland-Democratic Left and Democratic Turkey Party (ANASOL-D) coalitions. He acted also in demolishing the REFAHYOL. After the February 28 process (Launched by the soldiers against the fundamentalist uprising caused by the Refahyol government), he launched political engineering, by saying "Either death or change!" He served as minister in three separate governments" (http://eurasiaresearch.com/nta/1224nta.htm). 
pursuing this strategy. The TOBB is one of the most important sites where this strategy bore fruit for the GSO. To quote Göncui:

The GSO is the only chamber of industry in the region, other than Adana. We do not have the luxury to make a mistake. We are supposed to speak prudently. Thus, the Gaziantep Chamber of Industry is known as an institution whose predictions come true. Thus it emerged as a credible chamber. Because the chamber represents Gaziantep, Gaziantep also emerged as a city which is taken seriously. While it was being represented with one delegate in the TOBB at the beginning, now it is represented with three delegates. Our president of the chamber is on its management board. Our president of the [chamber] assembly is on the industry council. Since 1980, Gaziantep has sent ministers to every government. If Gaziantep says something to the benefit of society, [they] think that this should be done. ${ }^{201}$

Gönciu's comment indicates his belief that increasing the credibility of the chamber is the key to success. This credibility comes not only from the precision of their predictions or the quality of their proposals, but also from the association of the formulation of their interests with the interests of their locality and Turkish society in general. What the GSO says is good for Gaziantep is equated with what is good for Turkish society. This formulation reflects the corporate regime's concern to establish Gaziantep's cause as a national one in the eyes of the political apex of the state as well as the umbrella business associations. As Göncï states, this strategy worked in the case of the TOBB, where Koçer is its current vice president.

Newly established umbrella business associations constituted another strategic venue of representation. Gaziantep-based entrepreneurs' attempts to capture the

\footnotetext{
${ }^{201}$ INTERVIEW WITH KÜRŞAT GÖNCÜ.
} 
leadership of such associations aim not only to enhance the political visibility of Gaziantep in the eyes of the political apex of the state, but also to redefine the content of "national interest" in favour of the Anatolian capital, and thus Gaziantep's bourgeoisie. An important instance of this re-scaling strategy is the GAGIAD's success in capturing the presidency of the TÜGİK. Erhan Özmen, an ex-president of the GAGİAD, became the president of the TÜGIK in 2002. Before he became the president, he served as the vice-president of the TÜGIK, which helped him gain support from other GİADs in his bid for the presidency. His vision as a candidate involved two important goals: a) to increase the credibility and influence of the TÜGIK in Turkey's problems; and b) to promote the cause of Anatolian capital. To quote:

'I would not be able to ignore Anatolia's calling Gaziantep to duty. For this reason I officially declared my candidacy'.... Özmen, who claimed that Turkey has been ruled from metropolitan cities like İstanbul, Ankara, İzmir and [that] Anatolia ['s contribution to] ... production and emloyment has been ignored, continued as follows: 'This situation led to the development of one region, while other regions remained considerably underdeveloped. But, there is the phenomenon of Anatolia, too. When we look at the last 15 years in retrospect, we see that provinces such as Gaziantep, Maraş, Kayseri, Konya, [and] Denizli made great progress in terms of providing support to production, employment and SMEs. These SMEs produced despite all problems and difficulties. [They] provided employment, contributing to the social infrastucture, [they] realised social peace. It was SMEs that have been affected by every crisis, too. This power/force had to assume the responsibility at certain points. At this point we arrived, Anatolia gave Gaziantep the duty for the TÜGIK' (Newspaper article from Finansal Forum 28 May 2002, reprinted in Genç Çizgi 2002 (4)). ${ }^{202}$

\footnotetext{
202 (Translated from Turkish by the author). Here, let me give a brief anectode about the TÜGiK elections, which was transmitted during an informal talk: The story is that members of the GAGIAD attended the general meeting of the TÜGIK en masse. They rented a plane and all flew to İstanbul, increasing their numerical strength in voting, and this played an important role in capturing the presidency. This story tells us how determined and serious the GAGIAD members and its leadership are about their cause.
} 
Özmen's justification of his candidacy stands out as a nice summary of the cause Gaziantep's corporate regime has been promoting. ${ }^{203}$ The attempt to reach the apex of TÜGIK can also be seen a part of the territorial re-scaling strategy of organising an Anatolian solidarity to challenge the metropolitan centres of Turkish capitalism. This awareness also indicates that in political terms, Anatolian industrial capital is now feeling politically powerful enough to 'assume responsibility at certain points', to quote Özmen.

The aim of the institutional representation strategies was not simply to challenge the issues of national scale, but also to use such connections to support the re-scaling process of Gaziantep's local accumulation strategy, especially through the establishment of stronger ties with international markets and interlocutors. The best example in this regard is the lobbying activities of Gaziantep's corporate regime leaders inside the DEIK ${ }^{204}$ (the Foreign Economic Relations Board). The DEİK is a business

203 The claim to promote the influence of the TÜGIK in Turkish politics, apart from the TOBB and the
TÜSIAD, seems to contradict the idea of keeping Gaziantep's bourgeoisie as a single actor. Özmen's
statement could be read as a strong affirmation of the GAGIAD's individuality in Gaziantep's local
politics. It could, however, also be read as a tactical move to attract the support of the TÜGIK
membership, without having serious implications for the local coalition in Gaziantep. As we made clear
in Chapter 4, there is now an established and strong tradition of continuity between the leadership of the
GAGİAD and theGSO, the GAGIAD serving as the cradle of the GSO's leadership.

${ }^{204}$ Legal status: "DEIK was formed in 1988 and gained its legal status as a private sector institution due to the enactment of the new regulation based on Law number 5174. According to the new regulation which came into force in December 2005, DEIK was re-founded by the prominent private sector institutions of Turkey such as unions, foundations and associations.

Due to its close collaboration with its "founding institutions" DEIK was able to expand its fields of service far beyond its members by embracing also the members of these institutions operating throughout Turkey. Therefore, the country-wide activities enabled DEIK to become an institution coordinating the foreign economic relations of the Turkish private sector."

Organisational structure: "The annual DEIK General Assembly meeting is composed of representatives from the founding private sector institutions, chairmen of the existing business councils, representatives appointed by the Board of TOBB (Union of Chambers and Commodity Exchanges of 
platform whose co-founders included the major business organisations operating at the national scale, as well as the foundations established to promote pro-business policies in Turkey. According to its founders, the main purpose of DEIK is

to pave the way for Turkey's economic, commercial, industrial and financial relations with foreign countries as well as international business communities. .... Acting on this mission, DEIK makes every endeavor to find new fields of cooperation in foreign markets ... In this respect DEIK is committed to maintain firm and close cooperation with its "counterpart organizations" including exchange of business information. Therefore, DEIK aims to provide a platform where the business community can meet to discuss issues that would contribute to the improvement of mutual understanding and business cooperation. DEIK acts as an intermediary between the public and private sector due to its close working relations with all governmental bodies and private sector institutions in Turkey, as well as relevant public authorities and private sector organizations in foreign countries (http://www.deik.org.tr/deikInfo eng.asp).

As noted, the DEIK was established at the national scale by the major national business associations in Turkey, and its organisational structure originally did not involve local branches with the exception of İstanbul where the DEIK's headquarters are located. Yet, business leaders of Gaziantep pressed for the creation of a local branch of the DEIK in Gaziantep, and eventually the GTO also became the official

Turkey) and honorary members. DEIK Board of Directors elected by the General Assembly for two years tenure are committed to ensuring coordination among the Business Councils, as well as supervising and assuring DEIK activities.

The Chairman of TOBB is also the Chairman of DEIK. The elected 6 and 8 representatives of the Board of Directors compose the DEIK Executive Board which conducts and coordinates DEIK activities in the light of the strategies and policies advised by the Board of Directors. The Deputy Chairman of Board of Directors is also the Chairman of the DEIK Executive Board" (http://www.deik.org.tr/deikInfo eng.asp). 
representative of the DEIK in Gaziantep, the first of its kind in the country. ${ }^{205}$ Local representation in the DEIK will increase the intensity of the relations between the business community of Gaziantep and the DEIK, and will make international partners/contacts of the DEIK more accessible to them. The GTO and the GSO are also establishing one-to-one relations with the chambers from the European Countries, including Germany and France, to collaborate in many different issues, including professional and organisational knowledge tranfer (also see the section "territorial strategies of representation: jumping scales for compensation", in Chapter 6). ${ }^{206}$

\section{Discourses of re-scaling: Reterritorialisation of the "national"}

As we saw in Chapter 3, Gaziantep's corporate regime has been active in promoting the discourses of "model" and "pioneer" city. These discourses have been carefully drafted to increase the political credibility of Gaziantep, and especially of its entrepreneurs in their dealings with the state and various national and international actors. This endeavour amounted to a challenge to the established territoriality of the definition of the national interest, rather than an attempt to label Gaziantep's experience as an alternative to a political economic framework where the national state occupies a central place.

\footnotetext{
${ }^{205}$ INTERVIEW WITH FIGGEN ÖĞÜT.

${ }^{206}$ INTERVIEW WITH MESUT ÖLÇAL.
} 
Given Logan and Molotch (1990)'s emphasis on the local media's statesmenlike role in their localities (as the compromise makers and as formulators of community identity) it is important to pay attention to how the local media portrays the identity of Gaziantep. The owner of the influential local newspaper Gaziantep'te Sabah emphasised the "cultural-strategic" significance of Gaziantep. For example, the world famous historical site Zeugma located near Gaziante $\mathrm{p}^{207}$ was the headquarters of the Roman army's eastern legion. According to the interviewee, Zeugma was located at the "Eastern frontier of the West", where the West(ern culture) ends and the East(ern culture) begins. ${ }^{208}$ Indeed, this spatial claim points to an explicit intellectual and cultural aspiration to emphasise the historical uniqueness of Gaziantep, and to distinguish the city, actually located in the Southeastern part of Turkey, from the "imagined community of the East", as imagined by the rest of Turkey and the World. When we think about the

\footnotetext{
${ }^{207}$ One of the most popular and worldly known historical sites around Gaziantep is Zeugma, an old Roman city. What is significant about this site for our study is the support of the local media, business associations (see the websites of GSO and GTO for example: www.gso.org.tr, www.gto.org.tr) and other local institutions to rescue the archeological findings, and their effort to turn the site into a constituent aspect of the city's identity, sometimes fiercely challenging the attempts by the Istanbul based museums and civil organisations to move the findings from the excavation site to Istanbul for exposition. The selection of that site as the symbol of Gaziantep expresses the city's cultural stance between different world-views and the choice its opinion leaders make between the civilisations and their corresponding political-economic frameworks.
}

${ }^{208}$ INTERVIEW WITH AYKUT TUZCU. In fact, the significance of the geographical location of Gaziantep in determining the city's role in history is undeniable. Gaziantep is located between Asia Minor (Anatolia) and Mesopotamia (part of the Fertile Crescent). According to UNESCO records, the first settlement in the area appeared around 5600 years ago: Dolichenos (Dülük in Turkish, as the older name of the area). The area was ruled by the Kingdom of Commanege, then Hittites, Assyrians, Persians, Alexander the Great, Selevkians, Romans, a number of Muslim Arabic and Turkish empires / states as well as autonomous princedoms, lords, including the Crusaders. The Ottomans took over the city in 1516 and it stayed within the boundaries of the empire until its fall, despite the rebellions by various lords of the regions and the attempts by rival states to capture the city several times. After the fall of the empire, Gaziantep remained within the boundaries of the Turkish republic (Gaziantep BSB Kültür Dergisi 1989 . $20012001,119-129)$. 
connotations of the term "West" (democracy, liberal market economy, etc), we come up with certain clues of the cultural and ideological orientation of those who identify themselves as representatives of the city of Gaziantep. Here, it is important to underline that the emphasis on the 'West', and thus the ideas of democracy, liberal market economy, etc, indicates the common concern is to increase the connectedness of Gaziantep with the global economy.

In fact, "Westernisation", has been one of the most important components of the foundational discourse of the Republic of Turkey. And the current re-scaling process of the Turkish state has been strongly influenced by the broader - hegemonic - project of becoming a member of the EU, which can be seen as a culmination of the Westernisation discourse. In this respect, the re-scaling discourses adopted by Gaziantep's corporate regime are neither independent of the broader aspirations of the politics at the national scale nor do they leave the state and the national conjecture out of sight (cf. Beller-Hann and Hann 2001, Chapter 9). Thus, the construction of ties with the world and the EU are becoming strategic fields of action. An important scalar strategy of representation pursued by Gaziantep's corporate regime, in this regard, is to locate Gaziantep between the nation state and the world/EU as a site of interaction where globalisation and the EU integration start to be felt and operationalised first. The 'model city' discourse, in this regard, was a means of marketing the local corporate regime at the national and international scale. It was constructed to convince the interlocutors that Gaziantep had the capacity of experimenting with economic and governing innovations, which would make it the best place to initiate different political 
economic re-scaling projects. Here, we have to note that Gaziantep's claim to be a national pioneer has been related not only to the future, but also to the past, especially by alluding to the role Gaziantep played in the national war of independence. ${ }^{209}$

To sum up, the re-scaling discourses have been consciously employed to portray Gaziantep as a jumping off point, to carry forward the political projects of globalisation and neoliberalism in the rest of Anatolia, in peace and harmony with the national discourses. In this respect, Gaziantep's corporate regime, also benefiting from the Anatolian Tiger discourse, has constructed its political image as a "national champion" especially against İstanbul, so as to re-define the territorial frame of reference of the term "national" in the re-scaling process of the Turkish political-economy.

\footnotetext{
${ }^{209}$ The $20^{\text {th }}$ century was a dramatic one for Antep, the Veteran City, or 'Gazi'-'Antep'. The First World War had ended with the collapse of the Ottoman Empire, leading to the emergence of a new republic, the Republic of Turkey. This transformation was the most painful one, especially for the inhabitants of a historically cosmopolitan Gaziantep. Gaziantep's population was mainly composed of Armenians and Turks, who had lived together in harmony for centuries, along with other smaller ethnic groups including Kurds, Arabs and Jews. The forced migration of the Armenian population from Eastern and Southern Anatolia marked the beginning of dramatic changes for Gaziantep. Although not all Armenians left Gaziantep in 1915, the events of 1915 prepared the ground for ethnic polarisation in the city. Gaziantep was invaded by English troops in January of 1919, then, taken over by the French with the support of an Armenian volunteer corps in early November of 1919. This further heightened the ethnic tensions in the city. Gaziantep's Turkish population initiated one of the earliest local resistance movements against the Allies' invasion of the Empire's territories. Thus, the "national" resistance in Gaziantep went beyond being an anti-imperialist struggle, and gained an ethnic character, leading to the ethnic homogenisation of the city, with the withdrawal of the French troops and the Armenian population following the Ankara agreement signed between the new Turkish government and the French government in 1921.

The existence of a well-organised local bourgeoisie with a strong sense of local solidarity was a crucial factor behind the effective organisation of the local defence. The military struggle paved the way for the establishment of strong political connections between the local bourgeoisie of Gaziantep and the central governments of the republic. In fact, the city was given the title of 'Gazi' in 1921, meaning Veteran, by the People's Assembly. The city thus became a symbol of national resistance, as Atatürk himself stated in his congratulating message on the $15^{\text {th }}$ anniversary of Gaziantep's liberation (Gaziantep BSB Külttïr Dergisi 1989-2001 2001, 135).
} 


\section{Conclusion}

Our discussion so far indicated that the re-scaling process of the state influenced the content and target of institutional representation strategies of the corporate regime of Gaziantep. The state bureaucracy itself was not an interlocutor per se for the local bourgeoisie of Gaziantep. Yet, the presence or lack of specialised state agencies solely concentrating on specific, sectoral problems was an important factor influencing the institutional re-scaling strategies of the local bourgeoisie, and particularly the industrialists. Centralisation of the decision-making powers inside the national state made the post of the Prime Minister and the cabinet the key site to represent the interests of Gaziantep bourgeoisie.

We saw that Gaziantep was successful in establishing close ties with the Prime Ministers and the government ministers. This was especially true only for the leaders of the business associations and the large scale industrialists. In contrast, Esnaf associations found it difficult to get their voices heard by the government ministers, let alone the Prime Minister. We see that institutional representation strategies tend to increase significance of the logic of influence, especially given the fact that the interlocutors they are dealing with could not easily be substituted with others. Thus, institutional re-scaling strategies have a tendency to insert tensions inside the business associations and between the members of the corporate regime coalition, also shown in the case of the recent KÖY list. At this point, as we shall see in the next chapter, the territorial strategies of representation can prove to be useful by enriching the portfolio 
of interlocutors, and thus by lessening the pressure of the logic of influence over that of membership.

The problematic situation of the political parties as channels of representation indicates that the re-scaling process of the state alters the significance of different forms and channels of representation. As we saw, the national umbrella organisations provided a better channel and medium of representation to reach the political apex of the state. Here, of course, another struggle had to be waged, inside these umbrella organisations to capture their leadership. This challenge involved a political and discursive move to redefine the content and territorial frame of reference, of the national interest.

Nevertheless, we can not suggest that older forms of representation, and especially party politics as a channel of representation, completely lost their significance. Indeed, the composition of the government and the national assembly is crucial. Especially in the case of a single party government, which is best suited to run a centralised economic policy-making and resource distribution scheme, parliamentarism and party politics can return.

Recent developments in Gaziantep, in particular the success of the AKP-oriented candidates in capturing the control of the metropolitan municipality and the organised industrial district, testify to this claim. As we observed, the recent fracture inside Gaziantep's corporate regime emerged between two parties that employ, or at least prioritise, different representation strategies: between those that submerge their claims to the broader political agenda of a hierarchically organised political party, and 
relatively weaker in economic terms; and those who promote an autonomous local project through scalar strategies of representation, with a larger interlocutor portfolio, and in command of richer resources due to their spatial mobility. 


\section{CHAPTER - VI}

\section{"The scalar strategies of representation: Territorial strategies"}

In this chapter, I will concentrate on the territorial strategies of representation that have been employed by the local corporate regime of Gaziantep since the 1990s. These strategies have been pursued to facilitate a local accumulation strategy that has been shaped by rapid industrialisation in Gaziantep and the rise of a powerful local industrial bourgeoisie. As noted in Chapter 1, implementation of a local accumulation strategy requires the development of strategies to intervene in, and to contain, the state rescaling process that is meant to facilitate a national accumulation strategy shift. In the preceding chapter, we saw that the re-scaling of state intervention schemes - through centralisation of the provision of state benefits - did not provide the industrialists with a desirable policy framework, where state support schemes would be rationalised through further clarification of the terms of benefit provision, and institutionalisation of this process. This vagueness of the state support schemes and the unstable national political atmosphere of the 1990s led the GSO and the GTO to mobilise in order to stabilize their relations with the state, and to influence the decision-making process at key politicoinstitutional sites. For this purpose, Gaziantep's corporate regime leaders also developed a number of territorial strategies to supplement their institutional strategies of representation. I develop my analysis of these representation strategies in three sections. 
Section one addresses the territorial re-scaling, or 'scale-jumping', strategies that were employed by Gaziantep's corporate regime to influence the regional policy implemented by the national state. Despite the fact that the benefit schemes addressing individual firms were preferred over sector-specific and/or territorially delimited programs, the national state's post- 1980 intervention strategies were not completely devoid of a territorial frame of reference. Especially in the case of Southeastern Anatolia, where Gaziantep is located, there were a number of territorially defined state intervention programs at work, with the potential to contribute to Gaziantep's increasingly multi-scalar local accumulation process. Here I am referring to the GAP and the KÖY regime. Yet, Gaziantep was excluded from such schemes. Thus, Gaziantep's local corporate regime leaders were compelled to develop strategies to compensate for the missing benefits, and to escape the threat of "unfair competition" originating from the neighbouring provinces, which fell within the focus of the GAP and KÖY related state programs. This mobilisation aimed not only to capture the short term, tangible benefits provided by the state, but also to restructure the national-local, and inter-local, relations in the region around the primacy of the Gaziantep model, so as to institutionalise the political-economic superiority of Gaziantep in the region.

As we shall see in section two, increasing the political viability and credibility of the Gaziantep model, and thus influencing the long-term agenda and implementation process of the state's regional policy, was also an important factor that led Gaziantep's corporate regime to establish a series of formal and informal economic partnerships with international, supra-national and global actors. Yet, this was not the sole concern. 
The "open economy" policy of the post-1980 governments and the export orientation of the new national accumulation strategy offered a fruitful ground for the emergence of a local accumulation strategy that would increasingly target international markets. Yet, this opening process also increased the vulnerability of both the domestic and the local economy to global crises. Coupled with the political instabilities of the 1990s, mainly caused by the failure of the post- 1980 governments to facilitate a controlled integration with the global economy, this vulnerability pushed Gaziantep's corporate regime to seek ways to neutralise (new) domestic and global threats to the local accumulation process. This included exploration of new markets and sources of profit-making, and an active search for institutionalised collaborations with reliable political-economic partners influential in the global political economy, such as the EU and its member countries and the USA. 210 This representation strategy also aimed to respond to the insufficiency/incompetency of the state bureaucracy in the transfer of technology and knowledge to local actors (producers). The aim was not to replace the national state with the EU, but to supplement it.

As we shall see in section three, in this context, territorial re-scaling strategies were also employed to challenge older inter-local hierarchies that used to determine the path of integration of a certain locality with the international economy. In the case of Gaziantep, this amounted to a mobilisation to break İstanbul's monopoly on the establishment and maintenance of the relationship between the national economy and

210 The general secretary of GSO, Kürpat Göncü, also confirmed this point by stating that their relations with actors/institutions such as the EU, the USA, etc started to be shaped after the1980s. 
the global economy, by constructing direct links between Gaziantep and the global economy. This challenge was also necessitated by the economic threat coming from İstanbul, especially the pressure of the İstanbul-based financial capital over the industrialists of Anatolia, who badly needed financial support to stretch the spatial focus of local accumulation. There was also competition from İstanbul in certain industrial sectors, like textiles. To respond to such threats, Gaziantep's corporate regime leaders, and especially the GSO, mobilised to establish economic and political partnerships with other Anatolian Tigers like Denizli, located in the Western end of the country. In general, this strategy, along with attempts to find new international, global, etc, interlocutors and to influence the state's regional policy, was a reaction to the uneven geography of capitalist development in Turkey, which had also produced intra-class tensions within the Turkish bourgeoisie during the 1970s.

\section{Gaziantep and Southeastern Anatolia: Regional policy of the state, regional policy of the local corporate regime, and the territorial strategies of representation}

As we saw in Chapter 3, two territorially framed state programs constituted the heart of the state's post-1980 regional policy in Southeastern Anatolia: the KÖY program and the GAP. Despite the fact that Gaziantep was also located in the region, it had been left outside the scope of these programs. 211 According to the leaders of the corporate

211 In fact, Gaziantep was not granted KÖY status after 1980, following the coup, when the number of KÖY provinces was almost halved on the grounds of rationality. The number fell from 40 down to 25 , 
regime, this was "punishment of success". They asserted that despite the central economic role designated to Gaziantep in the GAP development plan, ${ }^{212}$ the state's regional incentive strategies worked to the disadvantage of Gaziantep's economy. While the economically underdeveloped provinces, which involved provinces surrounding Gaziantep, could tap the benefits and incentives offered by the GAP and the KÖY programs, Gaziantep was denied these resources on the grounds that it already had a developed economy. This approach was perceived as a threat to the 'productive potential (read economic dominance) of the city.'

To contain and overcome this 'threat', the corporate regime leaders formulated, and began to implement, two strategies: a) direct investment in other provinces and cities of the region by Gaziantep based firms, to benefit from the incentive scheme of the state, a strategy which could eventually curb the development of truly local firms in that city/province; and b) to locate Gaziantep between the state/international actors and other cities/provinces of the region, turning Gaziantep into an institutional interface between those localities and other scales of political-economy. We shall touch upon that

out of the 67 provinces of Turkey. The post 1980 KÖY regime was based on a further differentiation between KÖY of $1^{\text {st }}$ degree and KÖY of $2^{\text {nd }}$ degree, the latter being less privileged. Gaziantep was not given the status of KÖY-2 either. Ironically, this differentiation was abolished effectively after 1996, when all 38 provinces were considered to be KÖY of the first degree, and as of 1999, the regime covered 50 provinces out of 81 , all being considered of the first degree KÖYs. Thus, in the 1990s, the KÖY regime lost its discipline again, and served as a means of political distribution of economic privileges in the parliament.

212 The GAP master plan designated Gaziantep as an export centre, the region's door opening to the world, which will also assume important (service, education, culture and trade) functions (Ay 1997, 4445). 
second point later. As far as we are concerned with the first strategy, let me quote Nejat Koçer (the GSO's president):

Gaziantep Chamber of Industry's president Nejat Koçer is making a comparison, reminding [us] that he went to Jordan a short while ago: 'Jordan's population is around 5.5 million. Those working in industry are reported to be at the level of two hundred thousand people. Those working in industry in Gaziantep are around one hundred and twenty thousand. Viewed that way Gaziantep is almost as large as a country'. Gaziantep seems to have outpaced itself.

At this point Nejat Koçer made a suggestion:

'In Adiyaman, right under our nose, there are 8 Gaziantep oriented investments in total. Let the government develop an incentive system with the 'negotiation method' for us [Gaziantep's industrialists] targeting Adryaman. We do not want money or anything. Let incentive models be developed in SSK [Social Insurances Institution] premiums, tax, energy so that we will go there and create an investment boom' (Interview with Koçer, Hürriyet 24 Octoer 2003, emphases added). 213

Koçer's suggestions indicate that the corporate regime in Gaziantep and the industrialists in particular were actively searching for ways to bypass the regional incentive policy of the state. The current level of investments in Adryaman, including the investments of the SANKO group (owned by the GSO assembly president), indicates that the industrialists of Gaziantep have already been pursuing this strategy for a while. What is striking about Koçer's proposal is that the industrialists of Gaziantep are framed as the "potential implementers of the state's regional policy" aiming to overcome uneven development, without including Gaziantep in this territorial framework. Interestingly, the logic of this suggestion could be seen essentially as 
'contracting-out or privatisation of the task of regional development', which is thought to be a public responsibility, given the Keynesian roots of the idea of regional development (cf. Brenner 2004).

Indeed, the above proposal gives us a clear picture of the boundary of the local corporate regime's agenda and the degree of its inclusiveness. Koçer's suggestion expresses a compromise between the demands of the local corporate regime and the state's regional policy. As they give up on the claim of inclusion of Gaziantep in the state's territorially framed programs, which would be accessible to all entrepreneurs in Gaziantep, the corporate regime leaders push for a program whose benefits will be available only to those firms that are strong enough to invest in Adiyaman. In other words, a possible modification in the state's regional policy along the suggested lines will mainly serve those companies that are also in control of the GSO and/or influential in Gaziantep's political economy. This will worsen the conditions of intra-local competition in Gaziantep to the disadvantage of the victims of this "territorial cage", i.e, to relatively smaller and politically less influential entrepreneurs.

This example indicates that local corporate regimes, and especially those established with a re-scaling agenda, have to continuously negotiate a thin line between inclusion and exclusion (cf. Swyngedouw 1997b). In other words, as they re-scale the boundaries of local governance, they do this at the expense of the integrity of local policies and the stability of local governance arrangements. This inclusion-exclusion tension also hits the institutional heart of the leading players of the local corporate regimes, namely the local business associations. Here, especially the tensions between 
the logic of membership and the logic of influence are at work. When the need for a compromise with state policies arises, this will definitely increase the pressure of the logic of influence over the logic of membership, putting the political integrity of the business associations and the local corporate regime at peril.

Some further claims can be put forward regarding the relationship between the emergence of local entrepreneurialism and the state re-scaling process. First, as we saw in Chapters 2 and 4, the political activism of the local bourgeoisie in Turkey preceded the re-scaling of the internal organisation of the state, and of its forms of intervention during the post-1980 period. Thus, the state re-scaling of this period can not be seen as the root cause of an emergent entrepreneurialism led by the local bourgeoisie, but only as a catalyst that facilitated this process in the case of Gaziantep. At this point, it becomes important to pay attention to the ways that state interventions of the post- 1980 period influenced the accumulation strategy of an already (politically) mobilised local bourgeoisie, and thus the local agenda formation process. This leads us to the argument below.

Second, as our discussions in Chapter 5 and Koçer's above suggestion indicate, the political mobilisation of the local bourgeoisie, which produced local entrepreneurialism as a dominant form of local governance, should be understood as a process of local policy capacity building, by bypassing the obstacles to their local agenda. This is especially true for these local mobilisations following a multi-scalar local accumulation strategy. In our case, Gaziantep's local corporate regime leaders tried to increase their room for maneuver by challenging the government policies 
introduced to facilitate a new national accumulation strategy, and to modify the (rescaled) intervention schemes. When combined with our discussions in Chapter 4 , this observation tells us that the state re-scaling process does not amount to downloading a governance capacity to the local level smoothly and in a zero-sum manner (also see Chapter 1). Local governance capacity is actually increased during the active pursuit of a local agenda, and partially by responding to the challenges posed by the state policies.

Third, it seems that Keynesian influences do not completely disappear from state interventions during the rule of neoliberal governments, even though such concerns surface only in specific cases, such as Southeastern Anatolia. In such cases, the pressure for the adoption of locational policies (Brenner 2004) comes from the localities, not from the state. As mentioned earlier, locational policies are developed by taking local economic differences into account, and state benefits are distributed on a competitive basis. In such a scheme, entrepreneurial localities will be in a more advantageous position. In our case, the claim for extension of territorially framed state programs such as the KÖY and the GAP to Gaziantep is justified on the grounds of "efficiency" and the presence of entrepreneurs, a factor missing in other provinces/cities, according to the leaders of Gaziantep's business associations. ${ }^{214}$ As far as industrialisation and commercial activities are concerned, there is also a common emphasis among the local bourgeoisie on the "natural" division of labour between the localities in the region. 215

\footnotetext{
214 As mentioned earlier, the last KÖY decree passed by the current AKP government did not include Gaziantep either, despite the earlier claims and promises of the government to do so.

215 INTERVIEWS WITH MUHARREM BALAT, MUSTAFA GEYLANI
} 
According to this view, Gaziantep's lack of agricultural land, underground resources, etc., led the people of Gaziantep to be pre-occupied with artisans and commerce throughout its history. It does not make sense, according to this local view, for a town where there are no entrepreneurs to industrialise. While criticising the exclusion of Gaziantep from the last KÖY program list, Koçer argues that incentives will not be helpful if there are no entrepreneurs to make use of them. According to Koçer,

to be surrounded by provinces [which receive state] ... incentives could harm Gaziantep's power [capacity/enthusiasm] to produce, could blind the spirit of entrepreneurialism. Nobody has a right to let Gaziantep face such a risk ${ }^{216} \ldots$. It is those provinces possessing entrepeneurial and experienced people where incentives given by the state will be utilised fastest and most efficiently (Reported by Anatolian Agency - public news agency - 11 February 2005).

Here, a fourth point has to be made regarding the relationship between state rescaling and entrepreneurialism: state re-scaling does not necessarily prioritise entrepreneurialism as a favourable form of local governance. Indeed, there exist competing modes of local mobilisation adopting different representation strategies employed to influence state policies, regional policy in particular, in favour of a local agenda. In other words, territorialisation of the state re-scaling process takes place unevenly, and does not automatically spread entrepreneurialism across the localities of a region. And inter-local competition, if there is any, can not simply be explained in terms of an economic struggle between entrepreneurial localities. Instead, we can talk about a

216 This is harshly criticised by presidents of both the GTO and the GSO (Aslan 2002; Koçer 2000). Nejat Koçer claims that it would be a waste of money to try to develop all provinces. He calls this policy "punishment of success" $(2000,33)$. 
competition between different political models of local governance, taking different scales of political economy as their target and frame of action. I think the distinction Genieys makes between three strategies of political legitimation employed by the intermediary elite of different regions in Spain is apt here. According to Genieys,

The first repertoire of legitimation [is] based on the discursive strategies of announcing a 'loyalty option' with respect to the institutions of the autonomous Spanish state. ... The second repertoire rests on the 'voice option' of the intermediary elites wanting reform of the Autonomous Community statute. ... The third repertoire of legitimation of the intermediary elites which occupies a marginal position within the autonomous parliaments is charactarised by a 'defection' in the face of the present status (1998, 176-178).

I think a similar categorisation can be introduced here, as long as we are concerned with the question of how different localities respond to state policies in Southeastern Anatolia. Three different positions, adopted by three cities/provinces claiming to be the centre of the region for different reasons, can be delineated:

a) Şanluurfa, which follows the "loyalty option:" Even though the Kurdish movement is strong in the region, there are also Kurdish tribes that are loyal to the state and fight against the separatists. 217 This especially true for the tribes from Şanliurfa whose leaders have assumed important positions within the national governments, as ministers or consultants to the PM. In fact, this cooperation bore fruit. The regional headquarters

217 The powerful Kurdish tribes controlling Panlyurfa have always been faithful supporters of the True Path Party (DYP) whose previous leader (Süleyman Demirel) was associated with the GAP project. This observation was verbally transmitted by Osman Balaban, a colleague who was involved in GAP related research for a while. 
of the GAP program were established there, and Şanliurfa has been receiving substantial amounts of public investments in the region. As an agricultural centre, Şanlıurfa, and its economy, has greatly benefited from the GAP.

b) Diyarbakır, whose approach is closer to "defection:" Although the claims for autonomy or separatism subsided during the 2000s, Diyarbakır asserted its political and geographical dominance as the centre of the Kurdish movement. Here we have to note that the political presence of the state in the region is directly challenged. 218 The movement is well organised in political terms, around a centralised political party, and there is a vigorous presence of non-governmental organisations to promote the cause of this movement (Gambetti 2004; cf. Şimşek 2004). The present mayor of Greater Diyarbakır Municipality has been acting as the spokesman of the Kurdish movement, and has been active in establishing direct connections with the EU and other international actors so as to enhance the cultural and political autonomy of the region. The Kurdish movement has been using these connections as a source of pressure upon the Turkish state for official recognition of the Kurdish identity and for a redefinition of the political status of the region. Nevertheless, deep and severe socio-economic problems of the region remain secondary in the priority list of this Diyarbakır-centred movement. Ayata argues that this sort of an emphasis on "locality" did not work for the business leaders of Diyarbakır, and that there are those who are trying to introduce the

218 The following readings can be useful for further discussion on the history of the Kurdish movement and the issues related to the movement: Mutlu (2001); Aydınlı (2002); Gambetti (2004); Öktem (2004). 
model of Gaziantep in Diyarbakır. ${ }^{219}$ Mehmet Şirin Yiğit, the then-president of the Diyarbakır Chamber of Commerce and Industry, supports Ayata's observation (Interview with Yiğit in Görüş Feb-March 1998). 220

c) Gaziantep, which follows the "voice option:" The Gaziantep model appears as a middle point between these two extremes in terms of the relationship between the state and the localities. Just like Diyarbakır, the political leaders of Gaziantep, i.e, the local corporate regime leaders, try to develop partnerships with international, supra-national and global actors to promote its cause. Yet, as we saw, their project is not to bypass the national state or to weaken its policy-making power in the region. In fact, they try to set themselves up as the champions of a national cause, that of integration with the European Union. Nevertheless, unlike Şanlıurfa, the leaders of Gaziantep's corporate regime do not follow the loyalty option that prioritises the national scale as the target of representation. Theirs is not an endavour to implement a nationally defined grand project, but to interpret it to their advantage, and to have a say in the formulation and implementation of the state's policies in general, and its regional policy in particular.

The most important difference between the strategies adopted by Gaziantep's corporate regime leaders and the political leaders of Diyarbakır and Şanlıurfa is the attitude taken in their relations with Southeastern Anatolia. In the case of Şanliurfa, the tribal leaders ally themselves with the nation state to preserve the status quo in the

\footnotetext{
219 INTERVIEW WITH SENCER AYATA.

${ }^{220}$ Mehmet Şirin Yigit was the president of the Diyarbakır Chamber of Commerce and Industry, then.
} 
region. There is no separate strategy that aims to transform the political economy of the region, and especially the inter-local relations, or the inter-local hierarchy. In the case of Diyarbakır, the local politics and agenda is deeply intertwined with regional politics. Yet, there is no extra attempt to transform or challenge the inter-local relations or hierarchies as Diyarbakir has been the historical centre of the Kurdish movement. This is not the case with Gaziantep. Unlike Diyarbakır and Şanlıurfa, the local corporate regime leaders have been striving to establish Gaziantep as the political-economic centre of the regime. So, Gaziantep's has been a more interventionist approach in terms of the relations between the region and the city. The rise of this interventionism can be seen as the result of an increased regional awareness on the part of Gaziantep's corporate regime leaders, for three reasons: 1) the rapid industrialisation of the city and the associated need to control the regional market and to expand its economic hinterland;221 2) the GAP, which introduced a substantial stream of state benefits and public investment specific to the region, but which mainly bypassed Gaziantep, and the indirect contribution of the GAP to Gaziantep's economy (Ay 1997, 44); 3) the changing population and ethnic structure of Gaziantep due to in-migration caused by the poverty and military tension in the region. According to Ayata, the economic vitality of Gaziantep and its cosmopolitan tradition makes the city very attractive in the eyes of the potential (regional) in-migrant (Interview with Sencer Ayata, Milliyet 8 December 1999).

221 According to Mehmet Aslan (the president of the Gaziantep Chamber of Trade), Gaziantep has 20 provinces under its economic influence (Turkey had 80 provinces as of 1999) $(1999,237-238)$. 
This interventionism has been formulated into two discourses: a) the emphasis on the centrality of "economic development" as a regional political concern, against ethnicity and religion-based politics. According to the corporate regime leaders, Gaziantep's exemplary political success in dissolving ethnicity and religion-based political tensions through the active pursuit of an economy-centred (read pro-business) liberal local political agenda, turns Gaziantep into a political model for the region that will also work to the advantage of the national state by slowing down the momentum of separatism; b) the necessity to build regional economic strategies on the basis of an historically-formed, natural economic division of labour: "Not every city has to industrialise". Apparently, this discourse aims to challenge the state's regional policy in the case of Southeastern Anatolia, and to sustain the economic superiority of Gaziantep in the region, as its industrial and commercial centre.

Regarding the first discourse, according to the corporate regime leaders, "in Gaziantep, people are after their bread" and this is what makes Gaziantep a model city. Gaziantep's bourgeoisie and local politicans have always been proud of being citizens of a cosmopolitan city that reconciles ethnic differences (Ayata 1999). Their confidence in the superiority of Gaziantep's liberal, pro-business political model helped them develop a more positive attitude towards the Kurdish question. For example, the necessity to solve the Kurdish question was raised openly by Celal Doğan, the longtime mayor of Gaziantep. Another interesting instance of this emphasis is a statement by Mehmet Aslan (president of the GTO) given in 2002: "[i]t is not right to prevent those who are Turkish citizens [from] (and) speak[ing] their own language" 
(Gaziantep'te Sabah 30 May 2002). What is striking, though, is that this "brave" comment, as the newspaper calls it, was made in the context of Turkey's resistance to the EU's demands about the improvements in democratic rights, including language rights of the Kurdish population, as well as other ethnic groups. The prominence of the EU as a strong interlocutor for Gaziantep's economic re-scaling strategy was an important factor behind this challenging attitude of the corporate regime leaders.

Yet, there was a second and equally important concern, namely those leaders' concern with the integrity and stability of the local corporate regime. As we earlier saw, the rise of the MÜSIAD as a serious competitor to the leading cadre of the GSO, and the AKP's victory in Gaziantep at both national and local elections could be seen as indications of the fragility of the local corporate regime. In fact, a number of observers relate both developments to the changing ethnic composition of Gaziantep ${ }^{222}$ with the in-migration of Kurdish population from other provinces in the region due to the intense military conflict between the army and the PKK during the 1990s. A considerable section of these Kurdish in-migrants were peasants who had lost their only source of livelihood upon leaving their villages. This led to the concentration of poverty in Gaziantep at a time when economic crises were shaking the city's economy. ${ }^{223}$ This

222 INTERVIEWS WITH AYKUT TUZCU, ASIM GÜZEL, NURETTIN AKTAŞ; cf. INTERVIEW WITH MECIT BOZKURT. Nurettin Aktaş is a member of the parliament, in his third term as an MP. Last time he was elected from the AKP. Before he started his career as a politician/MP, Aktaş was a businessman and the founding president of the Southeastern Exporters' Union.

223 Yavuz Ay, the chief of the urban planning department of Greater Gaziantep Municipality notes that the migrants who settle in Gaziantep tend to be those who lack marketable skills, and that skilled labour prefers to move to bigger metropolises like İstanbul, İzmir, Adana, and Mersin. This has resulted in sedimentation of less skilled labour in Gaziantep, especially during the periods of economic austerity. 
phenomenon has increased the popularity of the AKP, a populist party that emphasises social justice. It is also important to note that the AKP is an inheritor of Erbakan's political tradition, which took Islam as a reference point rather than secular Turkish identity. The AKP's ideological emphasis on Islam was attractive to the Kurdish population of Eastern and Southeastern Anatolia, which brought electoral success to the AKP in the region and in Gaziantep. ${ }^{224}$

Although the recent return of single-party rule with the electoral victory of the AKP brought stability to national politics in general, and economic policies in particular, it also imposed a considerable cost on Gaziantep's corporate regime by increasing the pressure of the logic of influence over the local business associations. In addition, the AKP's electoral victory enhanced the credibility of the MÜSİAD in the context of the internal affairs of Gaziantep's local industrialists, thereby inserting a second tension into the GSO and the local corporate regime, by upsetting the intraorganisational power structure that determines the logic of membership. The changing ethnic composition of the industrialists further contributed to this challenge to the logic of membership. In fact, the social compositon of the in-migrants was heterogenous, in that ex-landlords and capital owners also came to Gaziantep, along with poor peasants. Those richer in-migrants bought the small and medium enterprises in Gaziantep that

This has resulted in a considerable increase in the number of people living below the poverty line in Gaziantep, and the emergence of shanty towns on the outskirts of the city (INTERVIEW WITH YAVUZ AY).

224 The AKP won the national elections in Gaziantep, which brought 7 out of $10 \mathrm{MP}$ posts to the AKP benches. In fact Gaziantep used to be a stronghold of the CHP - and social democratic parties - especially since the 1970 s, with the exception of the early post-1980 period. 
were about to go bankrupt due to the economic and political crises. ${ }^{225}$ It might be argued that the Islamist discourse of the MÜSİAD and its emphasis on solidarity among the smaller entrepreneurs of Anatolia attracted the political support of the immigrant entrepreneurs, which in turn enhanced the membership base of the MÜSİAD and its bargaining power. Of course, this argument has to be tested with further research, as we have not seen yet what sort of a local agenda will be promoted by those local entrepreners who coalesced under the Gaziantep branch of the MÜSİAD.

To reiterate, the territorial representation strategies pursued by Gaziantep's corporate regime aimed at rearranging inter-local relations in the region in a hierarchical manner with the broader goal of placing Gaziantep at the top, as the leader and representative of the region. The way Gaziantep's corporate regime leaders perceive the neighbouring province/city of Adiyaman is also indicative of its approach. Apparently, the policy approach demanded of the state could eventually create a dependent industrial structure in Adiyaman, further subordinating its economy to that of Gaziantep. As we shall see in detail in the following section, Gaziantep's corporate regime leaders' efforts to establish new partnerships with international, supra-national and global actors also serve this purpose. The GTO and the GSO established themselves as the contact point between the global/international actors and the other localities of the region, serving as the jumping off point for international interventions or help.

225 The change in the ethnicity of ownership of the industrial capital helped to keep the failing small and medium enterprises in Gaziantep alive, and provided a fresh source of capital to Gaziantep's economy, which had been badly affected by the volatility of financial capital and unreliability of banks. 
The corporate regime leaders' emphasis on the uniqueness of Gaziantep's experience in economic development and the difficulty of establishing an entrepreneurial spirit in other localities, contradicts their claim that Gaziantep constitutes a reliable model for regional politics. Thus, even if, for a moment, we agree with the argument that emerging (political) forms of local governance under neoliberalism are characterised by cooperation and horizontal relations, we can not jump to the conclusion that this logic can be stretched to the regional scale, and that this is a desirable form of governance on the part of those localities housing politically mobilised local bourgeoisies. We can argue that in the context of emerging regional governance new patterns of inter-local relations are not necessarily characterised by horizontal, network type of cooperation schemes, contrary to the observations made by the New Orthodoxy in urban and regional studies (cf. Lovering 1999; cf. MacLeod and Goodwin 1999). In fact, this does not suggest that such schemes are not, and cannot be, developed with other localities. Yet, horizontal partnerships are not necessarily established on a territorial basis, i.e, with the localities that are geographically close. Despite the fact that there are industrialised cities such as Mersin and Adana, located in the neighbouring Mediterranean region, and that in the GAP development plan Gaziantep is envisaged as part of a development corridor tying Şanlıurfa and Gaziantep with Mersin (the port city of Southeastern Anatolia) and Adana (the GAP Master Plan Executive Report), the GSO preferred to develop solidarity with Denizli, an Anatolian 
Tiger located at the other end of the country (in the Aegean region), so as to respond to domestic and/or international economic crises. 226

Gaziantep and the International actors: Jumping scales for 'compensation' and 'domination'

The second territorial re-scaling strategy pursued by the corporate regime of Gaziantep has been 'intensification of collaboration with international, supra-national and global actors' including, but not restricted to, the EU, the USA, etc. It must be underlined that this strategy has been adopted not to weaken the national state's policy-making capacity nor to introduce a substitute, but rather to influence the formulation and implementation of the national state's policies. The central concern has been to enhance the political credibility of Gaziantep's local bourgeoisie in their dealings with the national state, international actors and their region. Moreover, this strategy aims to contain the pressure of the logic of influence over the local business associations caused by the centralisation of national policy-making powers, and thus to seek international, supranational and global interlocutors. To summarise, the initiatives and endeavours informed by this strategy aim to 'jump scales for domination' (see Chapter 1).

\footnotetext{
${ }^{226}$ According to Sencer Ayata, there is a new, Greater Southern, region in the making whose future could (and should) be imagined in the context of the changing political configuration of the whole Middle East. And, of course, this is a projection at this point (INTERVIEW WITH SENCER AYATA). Yet, it could be argued that these projected developments may compel the corporate regime to revise its long-term strategies targeting Southeastern Anatolia, because, unlike Panlyurfa and Diyarbakyr, Adana and Mersin are industrialised cities housing traditionally strong local bourgeoisies, with a separate chamber of industry in Adana (cf. INTERVIEW WITH KÜRŞAT GÖNCÜ).
} 
There is a second set of concerns whose underlying theme is 'compensation'. One of the central concerns, in this regard, is to secure what is missing in the provision of state services that would otherwise be of help in promoting a multi-scalar accumulation strategy. This territorial re-scaling strategy adopted by Gaziantep's corporate regime is also a response to the local capitalist accumulation crises that could be sparked by national economic crises and/or global economic crises, as well as local and non-local obstacles to local capital accumulation. To be more specific, these strategies are pursued a) to expand the market base of the local industry, which now becomes a major problem due to shrinking domestic markets; b) to respond to the inadequacy of the state bureaucracy in the tranfer of technology and knowledge to the local actors (producers); and c) to escape the harmful consequences of domestic political and economic crises.

\section{Territorial strategies of representation: jumping scales for domination}

The EU constitutes one of the most significant interlocutors for Gaziantep's corporate regime. As we saw earlier, Turkey's accession to the EU is a national project that can be understood in relation to the older ideals of Westernisation, modernisation, and economic integration with the global capitalist economy. Thus, construction of a longlasting partnership between Gaziantep and the EU related institutions, as well as its member countries like Italy, is seen to greatly enhance the legitimacy and influence of Gaziantep's corporate regime in the domestic/national and regional political-economy. Moreover, by acting as a pioneer in the establishment of EU related institutions in 
Turkey, Gaziantep's corporate regime leaders also hope to secure a privileged position in receiving the financial and non-financial benefits provided by the EU to facilitate the integration process.

Here, we should note that the corporate regime leaders always have to play a double-edged game of re-scaling that targets the relationship between the EU and the Turkish state. According to them, the European Union and the state are complementary partners, rather than alternatives to each other. ${ }^{227}$ As already mentioned, having good relations with the EU is definitely seen as a way to attract attention of the national state to Gaziantep, enhancing the regime leaders' political credibility. This conclusion equally applies to the relations between the political apex of the state and the corporate regime leaders. As Davies argues, if a city is not a global city par excellence, then its connections with the state will become more vital in order to open up the global markets and to establish contacts with international/global institutions. Using the UK example, Davies argues that "there was little evidence that place-marketing partnerships were having an impact on investment decisions. The problem for most cities may be that they do not have the global profile of places like New York, London, and Tokyo. Thus, global firms make their approaches at the national level ... and localities rely on regional and national bodies for patronage" $(2003,264)$. In fact, the same point was made by Aynur Atay 228 , according to whom "once you you talk about the foreign investors, you

227 INTERVIEW WITH MESUT ÖLÇAL

228 A policy specialist who previously worked for the GAP-GIDEM in Gaziantep (a business support centre we discuss soon) and is now the secretary of the GAGEV, the economic development foundation of Gaziantep. 
have to convince them to choose Turkey first, and then GAP region in Turkey, and then Gaziantep in the GAP region."229

The recent projects of the 'European Union information office' hosted by the GTO, the 'USA information office' hosted by the GSO and the establishment of the GAGEV (Gaziantep'i Geliptirme Vakfi - the Foundation for the Development of Gaziantep) represent instances of this strategy of re-scaling for domination. To start with the first, the concept of an EU information office came as the result of an initiative by one of the corporate regime leaders of Gaziantep. In Turkey three offices were established initially, in İzmir, İstanbul and Gaziantep. The office in Gaziantep was the first ever established in a non-EU member country. Aykut Tuzcu, owner of the local newspaper Gaziantep'te Sabah invited Michael Leigh - the EU representative to Turkey - to Gaziantep in 1994 with the intention of introducing Gaziantep's economic success to Leigh. It worked. During his second visit to Gaziantep Leigh noted that "if the customs union 230 does not work in Gaziantep, it won't happen anywhere else (in Turkey)."231 During the same visit, when Tuzcu asked Leigh to open an information

\footnotetext{
229 INTERVIEW WITH AYNUR ATAY

${ }^{230}$ Note that Turkey joined the customs union in 1995.

231 INTERVIEW WITH AYKUT TUZCU - The same point was made repeatedly by other interviewees. Tuzcu and other opinion leaders in Gaziantep are taking the EU integration project quite seriously. The newspaper, Gaziantep'te SABAH has been carrying the flag in advancing relations with the EU. The May 9, 2002 issue of the newspaper - the Europe Day special issue, had this bolded headline: "Our only way/path is EUROPE". The issue includes letters written especially for that local newspaper, by the, then, EU commissioner to Turkey, Karen Fogg; Tansu Çiller (then head of the True Path Party, and ex-prime minister), Mesut Yilmaz (the head of Motherland Party, and ex-prime minister); Mustafa Taşar, the minister of tourism, and MP from Gaziantep; as well as the leaders from various civil society organisations in Gaziantep (also see the May 10, June 10, June 15, and 7 August 2002 issues of the same
} 
office in Gaziantep, Leigh responded that that would not be possible as there was no such EU legislation. Yet, when Leigh's mission in Turkey ended and he returned to work for the EU commission, he drafted such legislation and made sure that it passed. 232 The centre became operational on March 18, 1996 soon after the customs union took place. The office is hosted by the GTO. In fact, the GTO's role is more than that of host. The office was incorporated into the organisational body of the chamber and is now expanding, both in organisational terms and in terms of its focus of activities. The specialists at the office ( 3 people at the moment, but planned to double soon) are on the payroll of the GTO.233

The centre serves as an information channel that works both ways: answering the questions of those in Gaziantep interested in the EU, as well the questions about the economy of Gaziantep coming from the embassies (especially their trade and industry departments) of the EU countries in Turkey. It also organises seminars, etc. on the EU. The centre performs another critical function: it organises the trips of the representatives of the EU to Gaziantep and to the GAP region. ${ }^{234}$ These developments suggest that the

newspaper). Besides, as a newspaper, Gaziantep'te Sabah was not alone (see for example, Metropol 20 June 2002).

232 Tuzcu also mentioned that, after all this happened, he was invited to a workshop held by the EU, later (including the commission's president Romano Prodi and influential names such as Gunter Verheugen well known to the Turkish public, the commission member who used to be responsible for the EU expansion process).

233 INTERVIEW WITH FIGGEN ÖĞ̈̈T - Here, we should also mention that the director of the centre, Figen Ögüt, is the vice-secretary of the GTO, thus also acting as a bureaucrat of the GTO. Apparently, the changes in the interlocutor portfolio results in changes in the organisational structure of the chamber. 
centre (and the GTO) thus turned itself into a reliable partner in the eyes of the EU. This seems to have opened the doors of the EU to the GTO and Gaziantep. As Ögüt explained:

When we are to get in touch with someone from the EU via this representative [the office], we could reach them without facing any [EU] bureaucracy, directly, without any obstacles. ... Every year we have the economy and trade consultants of all the member and candidate countries of the EU over [to Gaziantep]. We do this quite often. They know us well because of the [information] bureau. We are a partner here for them. When they have something to do here, they call us first/directly. This is convenient for them too. When Turkey comes to their mind [when they have questions etc about Turkey] they call us. 235

In other words, Gaziantep and the GTO are slowly establishing themselves as institutional channels of communication between the region [and even the country] and the EU. This increases the credibility of Gaziantep's business associations in the eyes of both the Turkish state and the EU. Moreover, as Öğüt indicated, Gaziantep also acts as the pilot case for EU-based projects such as the EU business centre, which we will concentrate on in the following section. Along with the EU office, the USA information office hosted by the GSO represents another pioneering example in Turkey and in the region. After the successful initiation of these projects, the experience gained in Gaziantep was transferred to other cities ${ }^{236}$, and Gaziantep began to serve as the

234 The local newspapers / journals are full of news of visits of the EU members, foreign invester groups to Gaziantep (for example, see Yorum October 1996, 31, 39)

${ }^{235}$ INTERVIEW WITH FIGEN ÖĞÜT.

236 INTERVIEW WITH FIGEN ÖĞÜT. 
regional headquarters for projects introduced in cooperation with international interlocutors. ${ }^{237}$

The establishment of the GAGEV, the Foundation for the Development of Gaziantep (Gaziantep'i Geliştirme Vakfi), can be understood as another attempt to rescale the playing field of the corporate regime, and to establish better and closer relations with political and economic actors from the European Union and other international actors. The GAGEV was established following the example of the EGEV (Aegean Economy Foundation) ${ }^{238}$, as the collaboration of a number of local institutions, in March 1998: the Governor's Office, Gaziantep University (GAZÜ), the Greater Gaziantep Municipality, the GTO, the GSO, the Stock Exchange of Gaziantep, Gaziantep OSB (Organised Industrial District), Gaziantep OSB Industrialists Association, the GESOB, the GİB (Güneydoğu İhracatç1lar Birliği - the Southeast Exporters Union), the GAGİAD, the MÜSİAD, the HÜRSİAD, Gaziantep Club, the Gaziantep Textile and Industrialist Employers Association. The GAGEV's secretariat is assumed by the GTO. The raison d'etre of the GAGEV is to prepare Gaziantep for Turkey's accession to the EU, which is a national project, and to align the local policymaking process with the regional policies of the EU, and thus to institutionalise the rescaling strategy of the local corporate regime in this process.

${ }^{237}$ For example, the USA information centre in Kayseri works as the sub-branch of the one in Gaziantep. INTERVIEW WITH EBRU GÜLOĞLU.

238 INTERVIEW WITH AYKUT TUZCU. 
The GAGEV gives us an idea about the potential impact of this re-scaling strategy on local politics. The European region's literature suggests that the benefits and funds transferred via EU development projects provide an important stimulus to form local coalitions (Smouts 1998; Eberlein 1996; Smyrl, 1997). Yet, the coalition pattern imposed by such a re-scaling project has the capacity to alter the composition or the terms of agreement constituting the present local corporate regime. ${ }^{239}$ The coalition to be formed to reach such a goal - i.e, getting direct institutional/financial support of the EU, requires a broader local support base. Hence, the corporate regime leaders have to reach a compromise with the challenging groups if they are to broaden the coalition base, which is not an easy task. ${ }^{240}$ It should come as no surprise that a need was felt to re-vitalise the GAGEV, and to re-think its function, seven years from its establishment.

In 2005, the prominent names behind the GAGEV, such as Mustafa Geylani241 and the then-governor of Gaziantep, Lütfullah Bilgin, declared the determination of the members of the GAGEV to expand the spectrum of its partnership so as to include NGOs and the social and cultural projects:

\footnotetext{
${ }^{239}$ From the perspective of those who would be the beneficiaries - yet not the initiators - of such projects, such as Esnaf, there is always a certain degree of disbelief / suspicion given their previous experience with similar projects (of smaller scale) introduced in Gaziantep (INTERVIEW WITH VAKKAS KATIRLI). ${ }^{240}$ Apparently, the composition of the membership of the GAGEV indicates that it involves groups such
as the MÜSİA.

${ }^{241}$ INTERVIEW WITH MUSTAFA GEYLANI.
} 
In the process of accession to the European Union (EU), whereby activities of civil society organisations 242 [non-governmental organisations] gain importance, there is a great need for an understanding [that will] produc[e] projects by doing research, and [will] implement them, providing social service [employing] educated, informed, contemporary and modern human resources. The Foundation for the Development of Gaziantep will produce projects for Gaziantep to become a world city in cultural and social terms as much as in economic and commercial terms. The GAGEV's member authorities and representatives of civil society organisations reached [an] agreement for this collaboration possessing the strong will and dynamics of Gaziantep to work $\begin{array}{llll}\text { more } & \text { effectively } & & \\ & & \end{array}$ (http://www.fuarplus.com/haberlerdunya.php?id=2170\&PHPSESSID=a3483d77 $\underline{0 \mathrm{e} 10 \mathrm{e} 567 \mathrm{ac} 2260727994 \mathrm{ca} 4 \mathrm{a})}{ }^{243}$

Thus, we can conclude that the strategy of boundary spanning through scale-jumping can affect the dynamics of local politics by introducing new challenges to the existing local political compromise and agenda, as well as new opportunities for the groups previously excluded from the local governance arrangements. In other words, boundary spanning by scale-jumping also redefines the internal boundaries of local political arrangements.

\section{Territorial strategies of representation: jumping scales for compensation}

The broader goal of increasing the credibility and influence of Gaziantep in the eyes of the inter/supranational and global actors, the state and the region (as well as increasing Gaziantep's share in the pie in foreign investments) constitutes only one aspect of the

\footnotetext{
${ }^{242}$ Here, reader will notice that we use the term civil society organisations, which is a literal translation of NGOs in Turkish, rather than the term Non-Governmental Organisations. The reason why we prefer not to use NGO is that it defines civil society as that "what is not government", which builds upon a rather state-centric approach.
}

243 Translated from Turkish by the author. 
territorial re-scaling strategies pursued by the corporate regime. There is another important concern behind this re-scaling strategy: overcoming the economic obstacles to the local capital accumulation process in Gaziantep. It can be argued that for Gaziantep's industrialists there are currently five main issues to be resolved: a) improvement in the technology of production; b) institutionalisation of micro and small scale enterprises (better management skills); c) the crowding out of profitable sectors caused by volatility of entrepreneurs' entry to/exit from different sectors; d) the shrinking of the domestic markets; and e) the macro-economic crises sparked by both domestic and global political-economic instabilities.

To start with the last two issues, whose root causes are mainly extra-local, the president of the GSO, Nejat Koçer, stresses that new investments in Gaziantep should be made with the foreign markets in mind, where there is the opportunity for growth and enlargement, rather than the domestic market where, as of 2003, it seems that the prospects for stability are still dim (Editorial - Değişim May-June 2003, 2). Representatives of smaller producers (such as shoe producers) also emphasise that international markets are becoming more important as a result of the shrinking domestic market and the heating up of inter-local competition in certain sectors. ${ }^{244}$ In addition, the volatility of entry to/exit from certain sectors also creates intra-local competition 245 and leads to over-saturation of investments in certain sectors (Koçer, editorial - Değişim

244 INTERVIEW WITH BÜLENT AKŞIN.

245 INTERVIEW WITH YALCIN KONUKOĞLU 
May-June 2003, 2), thereby damaging the prospects for profit making, especially for small and medium enterprises. In that respect, finding new markets becomes the most urgent need of SMEs in Gaziantep. 246

Both global economic crises and domestic crises exacerbated by the Turkish economy's vulnerability to global economic influences are pushing the industrial producers to further globalise and to search for new international markets. According to the presidents of the GTO and the GSO, Gaziantep has been affected by every crisis since 1990 (Yorum 1998 (26-27), 18-19), thus pushing the entrepreneurs in Gaziantep to seek new contacts with global/international economic partners and markets. It seems that this strategy is now bearing fruit. The number of Gaziantep firms in the national “first 1000 exporters' list" increased from 24 in year 2004 to 35 in year 2005, thus increasing the relative weight of Gaziantep in the national exporters' league (Mehmet Aslan quoted in Referans Gazetesi 3 August 2005). This engagement is apparent in a business profile survey conducted in GAP provinces. Capitalists from Gaziantep are the ones who make international trips most often. In total, $72 \%$ of them go abroad, at least once a year, while this ratio is $50 \%$ for Adıyaman, $44 \%$ Batman, $34 \%$ for Diyarbakır, 56\% for Mardin, 35\% for Şanliurfa, and 49\% on average (Paksoy 2002, 62).

We can identify four different strategies pursued to establish such international/global contacts: 1) individual search for partners via the internet, business network services provided by state agencies (such as the KOSGEB), and international

\footnotetext{
246 INTERVIEW WITH HAMIT DOĞAN (policy specialist working for the EU Business centre in Gaziantep).
} 
fairs organised in different countries or in other cities of Turkey; 2) the organisation of fairs by the chambers (especially those by the GSO) in Gaziantep; 3) occasional group visits to the partner countries such as Italy (Hurriyet 24 October 2003) with the support of state officials, ministers (http://www.sirinnar.net/2005hab/12 01/12 04.htm), or to make new contacts; and 4) establishment of institutionalised partnerships with inter/supranational and global institutional actors to expand the portfolio of the markets to work with, and to transfer new production technologies and management skills into Gaziantep. It is especially this last category which is of interest to us here, because such collaborations have a capacity to have longer-lasting, structural impacts on the local economy and industry.

The EU is one of the most significant interlocutors for Gaziantep's corporate regime, in this regard. One of the benefits of building strong ties with the EU is the chance to secure access to a large and profitable market. Gaziantep's corporate regime has been an ardent supporter of the customs union with the EU. According to Göncï,

while there was opposition from İstanbul and many other industrialised cities to the customs union [with the European Union] process in 1995, it was only us, Gaziantep, who supported this [process]. To be able to compete [you] have to enter the same market, to open [yourself] to them. To be able to enter there, [there is a need] to change the models [of products] and the form of production. Now it is written as 'Made in Gaziantep'.247

The approach adopted by Gaziantep's corporate regime leaders indicates that they do not see the EU simply as a large and stable market. They consider the national accession

247 INTERVIEW WITH KÜRŞAT GÖNCÜ. 
to the EU and its market as a positive incentive to transform the institutional and technological infrastructure of Gaziantep's industry so as to create a competitive local economy. The "EU-Turkish Business Centre" that was established in Gaziantep in 2002 can be seen as a fruit this strategy. The centre is part of a broader collaboration between the EU commission and the TOBB. In the case of Gaziantep, the GSO and the GTO have acted as the local partners of this project.

There are three business centres in Turkey, one in İzmir, another in Kocaeli (the industrial workshop of İstanbul), and the third one is in Gaziantep. In fact, viewed from the EU side, the availability of local partners to work with, and especially their reliability in terms of their policy-making/implementation capacity, were key factors in the selection of the locality to start an EU business centre. 248 Once we consider the fact that there is a good number of cities whose economic performance and industrial structure could well provide a suitable atmosphere for such a centre (such as Kayseri, Denizli, Çorum, Bursa, Adana), and that it was Gaziantep that succeeded along with the leading industrial provinces/cities of Turkey, we can conclude that Gaziantep, and the GSO and the GTO in particular, have already reached a considerable level of credibility in the eyes of their European partners. We can also conclude that the institutional representation strategies of the GTO and the GSO inside the TOBB also bore fruit and translated into the EU business centre.

The establishment of the EU business centre in Gaziantep not only reflects the scale-jumping strategy of the GSO and the GTO, but is also an outcome of the 248 c.f. INTERVIEW WITH HAMITT DOĞAN. 
increasing significance of the EU as a determinant of the Turkish state's regional policy. ${ }^{249}$ In other words, the EU is becoming a serious interlocutor for all localities in the region by re-framing the national regional policy, as well as by shaping the implementation process of the regional development related programs. The story of the EU business centre in Gaziantep is a good example in this regard. In fact, the centre replaced a similar business support initiative in Gaziantep that was introduced as part of a GAP-related government program, the GAP-GIDEM (GAP Girişimci Destekleme Merkezi - the GAP Entrepreneur Support Centre). The program was initiated in 1996 and became operational in 1997 . The aim of the program was to give direction to entrepreneurs in their attempts to expand their market base, to establish international contacts, to employ new organisation and production technologies, and to provide them with financial support (www.gap.gov.tr/Turkish/Frames/fr23.html). The GAP-GIDDEM office in Gaziantep was closed as soon as the first phase of the program was terminated, and the GSO and the GTO did not participate in the second phase.

Actually, with the introduction of the second phase, the management of the GAP-GIDEM program changed hands. The first phase of the GAP-GIDEM (19972002) was planned and implemented by the GAP regional development agency (the GAP-BKI), and was financed by the UNDP. In the second phase (2002-present $)^{250}$, the

249 The law of regional development agencies that was passed to meet the requirements of the EU's regional funding (Law \# 5449, passed on January 25, 2006) constitutes the most recent example of this influence.

250 The UNDP staff was careful to distinguish the second phase of GIDEM from the first one. They give 2002 as the launching date of the project. 
EU substituted the UNDP as the financer, and this change in the financial source of the project was reflected in the management of the project. While the EU commission provides the financial support, in line with the EU's regional policies, the United Nations Development program assumes the function of program planning and implementation (Presentation prepared by Meral Sayın -the project coordinator- 17 July 2003). ${ }^{251}$ The GAP-BKI is only the beneficiary, and has a more passive role, only housing the project staff in their building, etc. Given the EU's approach to funding regional development related projects (cf. Bachtler et al. 2003) it should come as no surprise that the government was compelled to subcontract the design and implementation of the second phase of GAP-GIDEM to the UNDP.

In this regard, the lack of a coherent vision of regional economic development and industrialisation in the regional policy of the state, in the case of Southeastern Anatolia (cf. Yaşinok 1999, 100-101) rendered the state bureaucracy's management of the first phase ineffective, and led the government to employ the professional assistance of the UNDP to comply with the EU criteria. In the case of Gaziantep, too, the EU (commission)'s engagement with the second phase of GIDEMs (as the financer) determined the fate of the GAP-GIDEM centre in Gaziantep. The EU as the financer saw the presence of the GAP-GIDEM office in Gaziantep as a duplication of effort ${ }^{252}$,

\footnotetext{
251 INTERVIEW WITH MERAL SAYIN, the GAP-GIDEM/PHASE 2 COORDINATOR (works as a UNDP staff). Four provinces, Adıyaman, Diyarbakır, Mardin and Şanlıurfa remain within the focus of the second phase.

252 INTERVIEW WITH FIGEN ÖĞÜT.
} 
given that the EU business centre, as a better organised and more specialised program, was already under way in Gaziantep. ${ }^{253}$

There is an important drawback to this changing interlocutor profile, especially with the entrance of the EU to the regional policy scene. The interlocutor's priorities (and thus the logic of influence) can introduce new tensions to intra-organisational politics of the GSO and the GTO, especially by discriminating between different sections of their membership in the delivery of services and benefits.

Unlike the GAP-GIDEM project, especially of its first phase, the services provided by the EU business centre are not free. Financial soundness and sustainability are key priorities for a local partnership program to receive EU support (cf. Bateman 2000). For this reason, the financial survival of the business centre in Gaziantep became the top priority of its management, as financial support coming from the EU ended as of 2006. Although the centre, which will eventually gain the status of a private firm, is not profit-oriented, this priority of survival seems to have found its expression in the pricing policy of the centre. They charge 125 Euro/workday, as they work as a one-to-one consultancy firm ${ }^{254}$, a rate that would be quite difficult for smaller entrepreneurs to pay. Not surprisingly, it is the enterprises employing between 50 and 250 workers that most frequently take advantage of the centre's services.

\footnotetext{
253 According to Hamit Doğan - who served as a GIDEM specialist during the first phase and is now working for the EU business centre - opening up of an EU Business Centre was the prize given to the success of the first-phase GIDEM in Gaziantep. The business centre was built upon the experience from the Gaziantep branch of the GAP-GIDEM (INTERVIEW WITH HAMITT DOĞAN).

254 INTERVIEW WITH HAMITT DOĞAN.
} 
Another important instance of this strategy of scale-jumping for compensation, especially with the intention of expanding the portfolio of export-markets and attracting foreign capital to Gaziantep, is the lobbying activities of the presidents of the GSO and the GTO to convince the USA and Israel to set up a 'Free Trade Zone' in Gaziantep with export privileges to the USA, similar to the one that was established in Jordan by Israel and the USA. The GTO and the GSO have collaborated with the prime minister (then, Bülent Ecevit) to contact officials of the US and Israel for this purpose (Aslan 2000). In fact, there is already a free trade zone in Gaziantep that was established to boost exports and to attract foreign capital. Yet, it did not perform as expected. The intention was to revive this free trade zone by constructing long-lasting economic cooperation between Gaziantep and the USA and Israel.

A meeting took place between the presidents of the GTO and the GSO (Aslan and Koçer) and the ambassadors of these countries. According to Koçer:

What we really want is to sign a common trade agreement with both countries" [although he does not specify if this means with Gaziantep or with Turkey... and he continues] We explained [to them] the reasons the [free trade] zone should be established in Gaziantep. We explained that the USA and Israel's desire to be present/exist in the GAP region should integrate with Gaziantep which is the centre of the region by its nature. Besides, we demanded a common trade agreement. [We] explained the importance of Gaziantep in the [context of the] triangle of Israel, America and Turkey. The ambassadors have reacted to the issue sensitively. Moreover, we stopped talking about Gaziantep [and moved on to] have meetings/talks about the technical infrastructure of the region (Yorum 2000 (35), 5). ${ }^{255}$

255 Translated from Turkish by the author. 
It appears that leaders of the GTO and the GSO assume the functions of the ministries of trade and foreign affairs, and while doing this, they work closely with the political core of the state. To further increase the credibility of their initiative, they also formulated their demands with reference to the GAP, and the central economic role of Gaziantep in the region. From Koçer's account it also becomes clear that they followed the same strategy that they had pursued to establish their contacts with the EU, with explicit reference to Turkey's accession process to the EU. This time they located Gaziantep at the centre of the triangle between Turkey, Israel and the USA.

While it offers numerous advantages, this scale-jumping strategy is vulnerable to the political crises that stem from the international tensions and conflicts. One example of this is the fact that the USA gave up on this free trade zone project upon Turkey's refusal to give direct support to the USA's invasion of Iraq in 2003. Moreover, the invasion of Iraq severed Gaziantep's economic connections with the Middle Eastern market, which, in turn, led Gaziantep's corporate regime leaders explicitly to oppose American policies in the region. For example, the GTO and other important local bodies organised a huge demonstration called: "No to the War in Iraq", the first demonstration organised by a chamber in Turkey's history. 256

It can be argued that this fragility of international relations and markets is an important factor behind the adoption of a pro-European approach on the part of Gaziantep's corporate regime leaders. Obviously, the crisis-ridden nature of the

${ }^{256}$ INTERVIEW WITH MESUT ÖLÇAL. 
international and global political economy compels Gaziantep's corporate regime to seek stronger ties with more stable markets and polities like the EU, and thus further emphasises the necessity to adopt scale-jumping as a territorial strategy of representation.

\section{Gaziantep and other Anatolian Tigers: Re-making the historical-geography of capitalist accumulation in Turkey}

Construction of political and economic partnerships with other Anatolian tigers constituted another important re-scaling strategy adopted by the corporate regime in general, and the GSO in particular. As already noted, building close ties with other chambers of industry was crucial for the GSO, which aimed to strengthen its credibility inside the TOBB. In fact, the GSO was successful in this effort as Nejat Koçer, the president of the GSO, eventually became the vice president of the TOBB. Yet, this strategy has been adopted not only to enhance Gaziantep's credibility in the eyes of other Anatolian Tigers, but also to challenge the threat coming from the İstanbul-based capital to the local capital accumulation process in Gaziantep. This broader goal involved an endeavour to bypass İstanbul's dominance over the relationship between the domestic economy and the international economy. Therefore, this attempt of alliance-building with other Anatolian Tigers can be interpreted as an open challenge to the uneven geography of capitalist development in Turkey (see Map 6.1). In other words, this challenge involved attempts to alter the hierarchy of localities in the 
country, which is increasingly determined by the ability of a locality to control the intensity and the content of its interactions with national and global political-economic processes.

Map 6.1: Anatolian Tigers and the uneven development in Turkey

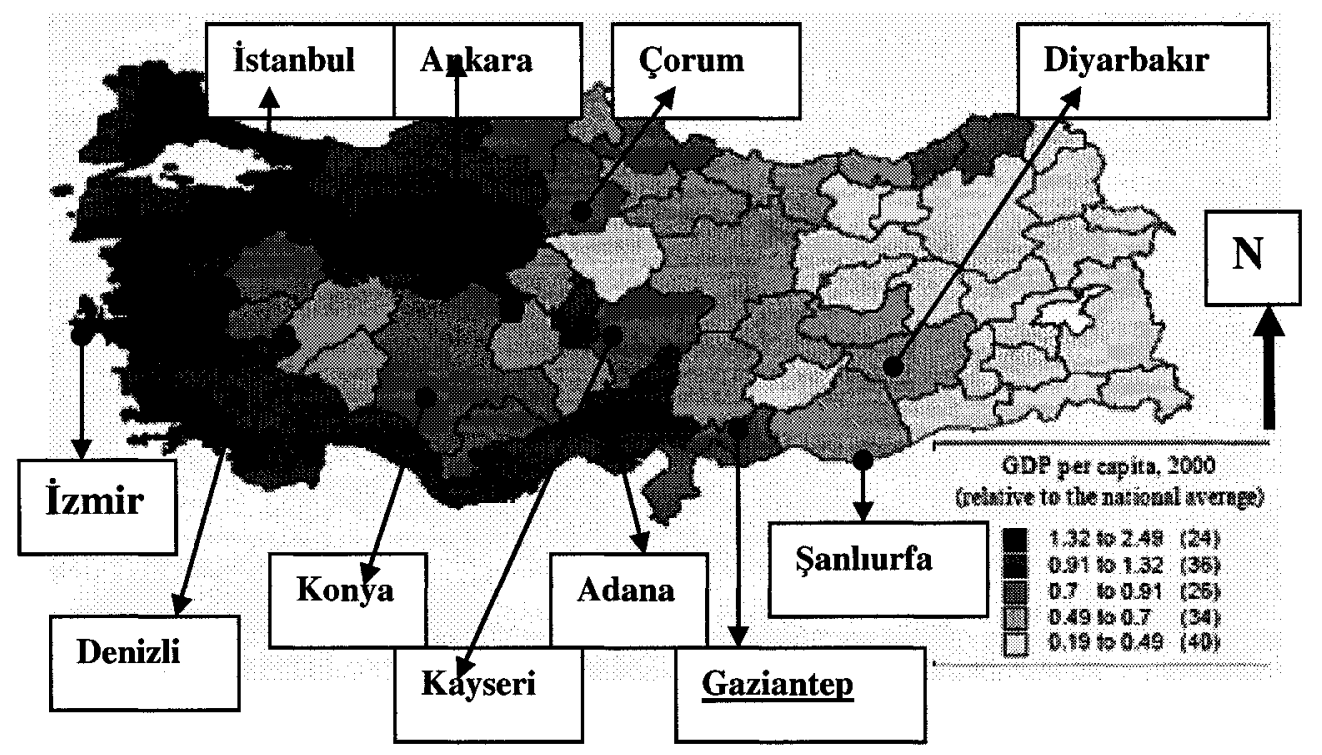

Source: Adapted from Kılıçaslan and Saral (2005).

The GSO's endeavour to build a partnership with the Denizli Chamber of Industry (Denizli Sanayi Odas1 - DSO) can be understood as an instance of this strategy. The pressure placed by the İstanbul-based financial capital on Gaziantep's industrialists during the national economic crisis of 2001 constitutes a striking example of how İstanbul's control over national economic resources could pose threats to the local accumulation strategy of Gaziantep. Another good example of İstanbul-oriented threats to Gaziantep's local accumulation strategy is the preference of the knitters in İstanbul, 
who potentially constitute the largest customer base for Gaziantep's thread producers, to import thread instead of buying it from Gaziantep. Their direct connections to the international markets helped the knitters in İstanbul to bypass those producers in Gaziantep. Here, Denizli's strong export orientation could help Gaziantep's industrialists to expand their own market base, while possible capital mergers could help both parties to overcome their vulnerability to banking capital. Now, let's take a closer look at how these two broader concerns led the GSO and the DSO to form an alliance.

Given the influence of the thread producers in the policy making of the GSO (including the president of the managerial board and the president of the assembly), a close collaboration scheme with the DSO and Denizli seemed a very attractive course of action, because Denizli uses the thread supplied by Gaziantep to produce towels and garments to export to foreign markets. As noted, Denizli is not the sole consumer of thread. İstanbul could provide a larger market for the thread producers of Gaziantep. Nevertheless, such collaboration never emerged between Gaziantep and İstanbul, where $95 \%$ of the garment producers are located. In fact, relations with the garment producers in İstanbul have been sour. This tension became explicit in determination of the rate of the "Value Added Tax" (VAT) on thread. The İstanbul Chamber of Garment Producers was against and resisted lowering the level of the VAT, which would eventually benefit the domestic thread producers. ${ }^{257}$ Shocked by this demand, Burnukara stated that "one,

257 including Gaziantep which contributes $20 \%$ of the national thread production - Burnukara did not mention if in terms of volume of product. 
then, starts to see bad intentions behind that [resistance to lowering of the VAT level]".258 It could be argued that what lies behind this move of the garment producers in İstanbul is their tendency to import thread from abroad, which - most probably - not only provides them with cheaper input, but also freedom from dependency on domestic thread producers.

The minutes of the first meeting of assemblies of the GSO and the DSO 259 also give a very clear picture of the concerns behind this collaboration. The first speaker, Abdülkadir Konukoğlu of the SANKO Holding (and the president of the GSO assembly) emphasised the division of labour between these two cities in the textile sector, noting that Denizli and Gaziantep have to collaborate in technological development. In addition, he stressed the importance of the coming together of large scale capitals for this purpose, which would effect a vertical integration in textile production, an important goal from the perspective of the GSO. Another important motive behind this close collaboration was the awareness and cohesion created by economic crises and especially the aggressive stance of the banks towards the industrialists. Bringing together the industrial capital of both cities under an umbrella holding company was seen as a solution to the problem of capital expansion needed for growth as well as technological and market development. The example Konukoğlu

\section{INTERVIEW WITH ALİ BURNUKARA}

259 The first meeting was held in May 2000, in Denizli, and the second one in October 2000 in Gaziantep. The following discussion is based on the second meeting's notes published on the website of the DSO (http://www.dso.org.tr/ekolarsiv/sayi8/dengaz.html). 
gives in that regard is the EGSD (Ege Giyim Sanayicileri Derneği - the Aegean Clothing Manufacturers' Association). ${ }^{260}$ In fact, the EGSD provides a host of services specific to the textile sector. Its main functions are determined by the logics of membership and implementation. Thus, it can be characterised as a service organisation that functions like a private firm (Schema 1.1). In this regard, it is no surprise that the EGSD founded a private company. Yet, going beyond the objective of providing services specific to the textile sector, the EGSD turned into a regional holding company, including a bank - EGS Bank - as one of its subsidiaries, whose shareholders are the member companies of the Aegean Clothing Manufacturers' Association. In that regard, the umbrella organisation - as a holding company - as proposed by Konukoğlu would coordinate between the economic activies of the industrialists of Gaziantep and Denizli, serving a purpose beyond company mergers by increasing the capital base of the industrial sector in both cities. Therefore, this supra-local - yet not regional - actor would offer a means of facilitating the economic collaboration of both cities. The

260 The Aegean Clothing Manufacturers' Association (EGSD) was established by 90 leading firms of the Aegean Region in the clothing industry in 1992. The EGSD's first aim is to create a strong identity by grouping the companies around the same structure through the sector.

EGSD groups companies from different branches of the clothing industry. It now has about 200 members such as ready-made garment manufacturers/exporters (knitted-woven) - domestic market manufacturers - apparel auxiliary materials - accessories and fabric providers, textile machines producers, and wholesalers.

EGSD cooperates with several institutions and associations from all over the world for new horizons through the industry.

EGSD's main activities are: organizing educational activities in order to strengthen the sector of textile and ready made garment in Aegean Region, participating in national and international fairs, arranging business trips in Turkey and abroad to investigate new technologies, matchmaking services, informing members about new markets and innovations, connecting members with foreign companies, cooperating with universities in order to provide qualified employees for members, promoting the region's textile and ready-made garment potential" (http://www.egsd.org.tr/indexeng.php?sayfa=egsd). 
theoretical and practical novelty of this suggestion is that it aims to replicate a politicaleconomic formation like the EGS, which is regional in character, between two cities that do not share such a close geographical and historical background.

Beyond establishing an economic coordination mechanism that would work like a holding company, this collaboration has a political mission. The committee, made up of the acting presidents and assembly presidents of the GSO and the DSO, could act as a common platform in their dealings with the (national) state. ${ }^{261}$ Such territorial representation strategy also aims to challenge and restructure the relations between the state and the local bourgeoisies - especially the industrialists - of recently industrialising Anatolian Tigers. It should, however, be noted that the policy-framing attempts of the state, especially in an effort to find out the problems of SMEs in Turkey, facilitated the emergence of a mutual understanding between the GSO and the DSO regarding their shared concerns. Actually, some of the statistical data used in the preceding chapters came from a study conducted and coordinated by the State Statistics Institute (D.İ.E.) for this purpose. The study concentrated on the cases of Gaziantep and Denizli, and compared their industrial structures and performances. The project started in 1996. In 1998 an international conference was held on this topic, which informed the further development of the project. As Süleyman İlgeri (the then-president of the DSO assembly) suggests, this state-initiated statistical research project, that aimed to understand the situation of these two "similar" cities, created an atmosphere and awareness of mutual interest in further collaboration of these two industrialising cities.

261 This point was made by Süleyman İlgeri of the DSO. 
A point has to be made here regarding the exclusive nature of this cooperation. Despite the adoption of a pro-Anatolian discourse by Gaziantep's corporate regime leaders, and their claim that Gaziantep and Denizli are true owners of this Anatolian revolution, there is a tendency to exclude other Anatolian Tigers from the partnership agenda of the DSO and the GSO. In fact, at the common assembly meeting of the DSO and the GSO a broader range of territorial cooperation was proposed by certain assembly members. ${ }^{262}$ This involved strectching the collaboration scheme between Gaziantep and Denizli to other Anatolian tigers like Konya. Konya is a city where industrial enterprises began to flourish in the 1990s using the savings of Turkish workers abroad, which were transferred to Turkey via networks of Islamic groups. Their economic success, labeled as the emergence of a truly Islamic economic model, was short-lived, however. These enterprises started to go bankrupt in the late 1990s especially after the Military Memorandum of February 28, 1997. Their failure to meet their promises to the stakeholders, and the attack of the media, the İstanbul-based large scale capital, and the army, on "Islamic capital", contributed to the collapse of such enterprises concentrated in cities like Konya. According to the DSO assembly member who suggested the expansion of the collaboration, the bankrupt firms had brought a significant amount of capital to the country, which had to remain in the country. The state would not be able to revive this potential. The industrialists of Gaziantep and Denizli should establish contacts with the industry of Konya to save them, and get this

${ }^{262}$ A DSO assembly member, Feridun Alpat, made this proposition. 
capital back into circulation. Yet, this suggestion was not taken seriously by the leaders of the GSO and the DSO, and it did not find a place in the final declaration document of the meeting.

Apparently, being an Anatolian Tiger does not automatically render a locality a desirable partner in the eyes of Gaziantep's industrialists. In fact, a quick look at the map of Turkey shows that Gaziantep is geographically very close to similar industrial towns such as Kayseri, Adana and Mersin. Nevertheless, the GSO did not rush to develop a cooperation scheme with the industrialists of these cities at times of political and economic crisis. An important reason behind this reluctance is that the very idea of 'Anatolian Tiger' is based on the neoliberal premise of (inter-local) competition. Given this emphasis, it is quite natural that localities competing for the same market (at least for the regional market) like Kayseri - as emphasised by many entrepreneurs from Gaziantep - would not make the best partner. Thus, it can be suggested that the Anatolian Tiger discourse, which, on the surface, refers to a political solidarity project among those cities, actually serves a re-scaling strategy of domination which targets not only İstanbul, but also other Anatolian Tigers, ultimately aiming to bring political superiority to Gaziantep against other localities, and to help Gaziantep climb the ladders of the inter-local hierarchy in Turkey.

The above discussion has indicated that sectoral concerns of the groups in control of the GSO determined the geographical orientation of the partnership strategy of Gaziantep's corporate regime. At this point, we see another face of the exclusive nature of this territorial representation strategy. In particular, I refer to the relations 
between thread producers, knitters, and garment producers in Gaziantep, who would be expected to develop a coordinated response to the economic crisis of 2001. Yet, these two groups followed different paths of action. Despite their position as natural buyers of thread produced in Gaziantep, the garment producers and knitters of Gaziantep, organised as an Esnaf association, were not invited to the partnership scheme between the GSO and the DSO. Moreover, during the times of economic crisis, the Gaziantep Chamber of Knitting/Knitters did not receive direct support from the GSO. They developed stronger and closer ties with those in İstanbul, who, as noted, had adopted a rather hostile approach to the thread producers. The chamber president Yıldırım stated that when the 2001 crisis broke out they met and consulted with the president of the İstanbul Chamber of Knitting/Knitters to deal with their problems, not with the local actors from Gaziantep, including the GSO.263 Given the strength of the garment/knitting sectors in İstanbul, it is understandable that those small producers in Gaziantep went to İstanbul rather than pushing for support from within the locality. Nevertheless, this surprising lack of solidarity between the thread producers and the knitters and garment producers of Gaziantep, and the preference of Gaziantep's thread producers to go for Denizli offering a larger and more reliable market base for their product, indicates that this territorial strategy pursued by the GSO might well work against the interests of certain local groups, or at least serve to marginalise their concerns in the formation process of Gaziantep's political-economic agenda.

263 INTERVIEW WITH MAHMUT YILDIRIM - Group Interview 


\section{Conclusion}

In this chapter, we discussed the scalar strategies of representation adopted by the business associations, and thus the corporate regime, in Gaziantep. These strategies have been developed at, and have targeted, three scales: the regional scale, the supra/international and/or global scale, and the national scale. To begin with the first: as noted, Gaziantep's local corporate regime leaders were forced to mobilise to compensate for the missing benefits due to the exclusion of Gaziantep from the national state's territorial programs, and to escape "unfair competition" coming from the neighbouring provinces. In other words, Gaziantep's corporate regime employed territorial strategies of representation to influence the formulation and implementation of state regional policies. Here, the concern was not simply to capture state benefits, or to get rid of unfair competition, or to maintain Gaziantep's currrent economic superiority in the region. As we saw, there were competing modes of local political mobilisation in the region, adopting different attitutes to the state re-scaling process. Gaziantep's local corporate regime was one of these political alternatives. The "competition" orientation of Gaziantep's corporate regime led them to develop a regional awareness and sensitivity to the regional policy of the state. The representation strategies they employed aimed to introduce structural, long-term changes in the relations between the localities in the region and the state, as well as in the inter-local hierarchy in the region. This competition orientation, however, did not exclude the possibility of establishing partnerships with other Anatolian Tigers like Denizli, as long 
as this partnership contributed to the competitiveness of Gaziantep. The partnership regime between Gaziantep and Denizli was the product of a mobilisation to challenge İstanbul's control over the international and global connections, and part of a political competition regarding the territorial framework of "national" interest. This strategy, along with other re-scaling strategies, can be seen as an instance of a broader intervention with the uneven geography of capitalist development in Turkey, which had also produced the intra-class tensions inside the Turkish bourgeoisie during the 1970 s. Then, given all these concerns, the territorial strategies of representation pursued by Gaziantep's corporate regime leaders, and especially the industrialists, can be seen as an attempt to alter the class relations condensed into the spatio-temporal fabric of the Turkish State (cf. Poulantzas 1978; cf. Duncan and Goodwin 1988; Brenner 2004).

The chapter also indicated that the local corporate regime pursued representation strategies targeting actors and institutions established at supra/inter-national and global scales to increase the regime's political credibility in the eyes of the national state and their region, and to facilitate the re-scaling of the local accumulation process. Yet, this territorial representation strategy had one more purpose: to lessen the pressure of the logic of influence over the logic of membership, especially within the GSO and the GTO, as a result of the increasing intensity of their interactions with the national state through the institutional strategies of representation. As our discussions in Chapters 1 and 4 indicated, the political stability of local business associations, and the autonomy and integrity of the local corporate regime, depend very much on striking a healthy balance between these two logics. Thus, broadening the portfolio of interlocutors 
becomes necessary to keep the local business associations and the local corporate regime together in the face of pressures coming from their dealings with the national state. Nevertheless, as the chapter also indicated, although the territorial representation strategies can remove the pressure of the logic of influence over the local business associations and the local corporate regime, the re-scaling of the territorial focus of local accumulation through these representation strategies can also increase the possibility of destabilisation (even dissolution) of the local corporate regime, by diversifying, and further fragmenting, the composition of the membership base of these business associations on the basis of their spatial mobility and capacity to adapt to the international and/or global markets, as well as by multiplying the number of participants to Gaziantep's local political economy. Thus, we can conclude that a local corporate regime established around a political economic re-scaling agenda, pursued through both institutional and territorial strategies, may be more fragile than one whose focus remains merely local. 


\section{CONCLUSION}

This study has examined the links between the recent rise of cities and regions as significant and strategic loci of policy-making and the changing place of the capitalist state in political economy and its spatiality. The city of Gaziantep, which is located in the Southeastern part of Turkey, constituted its empirical focus. The fact that Gaziantep started to industrialise rapidly from the 1980s onwards, a period during which neoliberal policy reforms began to be implemented in Turkey, brought this city - and a number of other similar cities called Anatolian Tigers - to the centre of attention both for scholars and policy-makers. Gaziantep was seen as the capital of the Anatolian Tigers and a successful model of local entrepreneurialism, which replaced the state's active involvement in economic development. In other words, Gaziantep's success was attributed to economic globalisation and a free-market economy.

Employing the rich theoretical insights offered by the scale literature, urban regime theory, and studies on business associations, I have offered an alternative explanation regarding the relationship between the rise of cities and regions, emphasizing the political dimension to local entrepreneurialism, and the changing role and nature of the capitalist state. Neil Brenner's conclusion that entrepreneurial local governance is a medium and expression of the re-scaling of the capitalist state constituted the departure point of my analysis. I argued, however, that Brenner's 
emphasis on the changing spatiality of the state's forms of internal organisation and intervention has to be supplemented by investigating the emerging forms of representation of this re-scaled state. As I have shown, this emphasis is necessary if we are to go beyond the analytical restrictions posed by an approach that sets these two phenomena as external to each other, and conceptualises their relationship in structural terms, ultimately arguing that state re-scaling begets local entrepreneurialism. Building upon this line of reasoning, my study concentrated on the question of local agency. In particular, it problematised in what ways the broader state re-scaling process contributed to the formation process of local agency and how this agency influenced the state re-scaling process.

I introduced the concept "scalar strategies of representation" to undertake this task. The concept is not an attempt to re-interpret an existing socio-political phenomenon employing a spatial language, but to make sense of certain empiricallyconstituted and observable changes in the role and place of the capitalist state in political economy. Moreover, the analytical orientation of the concept is also informed by the theoretical problematic of this study, which emphasises the role of the agency of social actors in the re-making of the capitalist state. Thus, unlike the traditional forms of representation that mainly correspond to the nation state as a unit of analysis, and take it as a pre-given and the prioritised scale of state organisation and representation, scalar strategies of representation, as a concept, refers to different social actors' efforts to reorganise and to coordinate emerging sites and schemes of policy-making so as to render them more favourable to their interests. Thus, as noted in the theory chapter, scalar 
strategies of representation can be conceptualised as instruments for shaping, coordinating and linking newly emerging structures, re-producing the "capitalist state as a condensed form of re-scaled social/class relations" that can no longer be constituted solely within the spatio-temporal matrix of the nation state (cf. Poulantzas 1978).

In the thesis, I employed the concept "local corporate regime" to refer to the politico-institutional form of an emerging local agency that is led by local bourgeois concerns, i.e, local entrepreneurialism, and located the local business associations to the core of local corporate regime formation. In this respect, the formation process of Gaziantep's local corporate regime and the scalar strategies of representation hatched and pursued by this regime constituted the empirical focus of this study.

Our discussions indicated that theoretical emphasis on the question of agency in general, especially by explaining the question of local entrepreneurialism from the lens of local bourgeois activism, and especially through local business associations, can help us detect the historical continuities inscribed into the present local entrepreneurialism, instead of seeing it as the expression of a neoliberal rupture in the politico-spatial organisation of the capitalist state, or as a series of local responses to a grand transformation set in motion by the national state. We saw that the roots of Gaziantep's entrepreneurialism, along with that of other Anatolian Tigers, go deeper into the intrabourgeoisie struggles in Turkey that emerged in the context of a Keynesian national accumulation regime, which marked a turning point in the relations between the state and the Turkish bourgeoisie. In other words, the emergence of local entrepreneurialism is not a product of the neoliberal era. The state re-scaling process that took place in an 
attempt to realise a shift towards an export-oriented open economic strategy only facilitated the emergence of this entrepreneurialism. In this regard, another important lesson that can be derived from our investigation is that this facilitation process did not work simply through careful and conscious employment of a series of positive incentives by the state that merely eased the mobilisation of the local bourgeoisie, and enhanced the significance of local governance by increasing the local policy-making capacity.

In fact, the re-scaling of state intervention and its internal organisation contributed to enhanced local policy-making capacity through decentralisation of policy-making and implementation powers, and necessary financial resources, to the local governments; promotion of a general pro-business political atmosphere in the country; and the opening up of the domestic and local economies through introduction of an export-oriented economic policy and the associated support schemes, which offered the local bourgeoisies new markets and sources of profit-making. Thus, it is important to note the state re-scaling through structural changes in the intervention schemes and state organisation had a facilitating role in the increasing significance of local governance and increased local policy-making capacity (Brenner 2004). Yet, our agency-centred analysis indicates that the growth in the local policy-making capacity came about also as a result of a series of responses - or, scalar strategies of representation - employed by the local business associations to overcome the obstacles to the local accumulation strategy posed by the re-scaling of state interventions and the re-scaling of the internal organisation of the state. Here, the main concern of these 
business associations was not simply to bypass the obstacles posed by these pre-given structural transformations. They, indeed, sought to re-shape and mould the scalar strategies of intervention and internal organisation of the state to their advantage, and thus were actively involved in the state re-scaling process as state-builders.

Thus, I argue that this second set of "negative" stimuli posed by the state rescaling process played a more critical role in the political mobilisation of the local bourgeoisie and the emergence of local entrepreneurialism, in a number of ways: first, the centralisation of economic policy-making and the intervention schemes during the neoliberal period, and the forms of representation preferred by the national governments indeed introduced quite unstable and exclusive support schemes that worked against the immediate interests of Gaziantep's local bourgeoisie, thereby compelling them to get mobilised in political terms and to seek new political channels of representation as well as new resources to promote their own local accumulation regime.

Second, the openness of the domestic and local economies inevitably increased their vulnerability to global political-economic crises. In the case of local economies in the developing world, the degree of their vulnerability to political-economic crises was further intensified by the fact that the control of economic institutions like IMF over the formation and implementation of national economic programs created a structural instability in the national political economy, as in the Turkish case, thereby contributing to the birth of a constant state of crisis and national policy paralysis. This was an important factor behind the mobilisation of the local bourgeoisie in Gaziantep, which 
forced the local business associations to seek reliable interlocutors and markets to work with.

Third, we saw that, change in the national accumulation strategy could immediately alter the sources of profit-making, thereby contributing to the transformation of the composition of the local bourgeoisie, and eventually to a shift in the intra-bourgeois balances. As Chapter 3 indicated, this process further sharpened the prominence of the industrial sector in Gaziantep, partially through the transfer of commercial capital into this sector. In fact, as commonly observed by students of Turkish political economy, the post-1980 era mainly worked for commercial and financial capital, and against the interest of industrial capital. ${ }^{264}$ Hence, the development in Gaziantep, i.e, the increasing attractiveness of the industrial sector, was not an intended outcome of a political project that favoured industrial capital. The increasing political mobilisation and significance of the industrialists in Gaziantep came as a response to the problems they faced in sustaining a pro-industrial local accumulation strategy in Gaziantep.

To reiterate, Gaziantep's local agency was constructed through political mobilisation of its local bourgeoisie, led by the industrial fraction, and took the form of a 'local corporate regime' whose main agenda was to promote and sustain a local accumulation regime whose focus became increasingly multi-scalar. Our discussions

\footnotetext{
264 The increase in the volume of national exports during the 1980s and 1990s was mainly generated by the full employment of idle capacities inherited from the pre-neoliberal era, and mainly in traditionally strong industrial sectors, not because of an expansion in the volume of industrial investments or technological improvement.
} 
indicated that this multi-scalar focus of the local accumulation strategy required the adoption of scalar strategies of representation, which resulted in the expansion of the range of participants who had a say in Gaziantep's local political economy. This effectively stretched the boundaries of the local political economy across scales, turning Gaziantep into the meeting point of different actors from different scales, which sometimes had conflicting interests. Therefore, the increasing political significance of local governance, especially when local entrepreneurialism was its dominant political form, came as a result of the active engagement of the local actors. In other words, the rise of local governance as a critical site of policy-making and political exchange was not a direct result of downloading of the national state's powers, resources and policymaking capacity to the local level.

We should avoid jumping to the conclusion that this increased significance of local governance is a product of local economic interests' endeavour to bypass the dominance of the national state and/or to construct a sphere of autonomy against the policy-making capacity of the national state. In the case of Gaziantep, there was an attempt to construct a new territorial matrix of governance and to manage and influence inter-scalar arrangements including the re-scaling process of the national state, and its relations with inter-national or supra-national bodies, to the advantage of local interests. Thus, it can be suggested that localities, and especially those that are politically mobilised, can also function as scale-managers, along with the national state (cf. Mahon and Keil 2006), and thus effectively shape the state re-scaling process. Here, we can use an analogy used by Henri Lefebvre who likens the production of space to a spider 
weaving a web (Lefebvre 1991). In our case, our spider was the corporate regime in Gaziantep which was busily involved in weaving its "space of engagement" (Cox 1998) through institutional and territorial representation strategies.

The findings of this study indicate that both concerns of domination and compensation, which informed both the territorial and institutional re-scaling strategies, stemmed from the local corporate regime's perception of inter-local relations mainly through the lens of a competition perspective, and that the state re-scaling process did not automatically trigger inter-local competition (at the national or regional scale). Only the entrepreneurially minded and mobilised localities saw other localities as potential competitors to themselves, thereby developing a more sensitive, pro-active and interventionist attitude towards those localities in their own regions and the country. Moreover, the competition did not simply occur to get more capital investment, or to capture the control of regional, domestic and international markets. There was also an attempt to establish their own neoliberal entrepreneurialism as the dominant political model for their region, as well as an attempt to define the very content of "national" interest and national bourgeoisie.

To summarise there were three different planes on which inter-local competition and struggle took place:

a) Competition between political models of national-local relations: In the case of Southeastern Anatolia, there were three models promoted by three localities, that of Şanlıurfa following the "loyalty" option; of Diyarbakır closer to the "defection" option; 
of Gaziantep following the "voice" option. The first two models took the national state as the target of their mobilisation strategies, so as to either weaken or strengthen its political presence in the region. The entrepreneurialism of Gaziantep's corporate regime, however, led the local corporate regime to develop strategies that aimed not only to influence the policy-making process within the institutional boundaries of the national state (bureaucratic and political), but also to restructure the relations between the other localities in the region and the state. Thus, the local corporate regime sought to place Gaziantep on top of the inter-local hierarchy in the region, and position Gaziantep as the region's representative to the national state. This was an attempt to transform and re-scale the territorialisation process of the state in the region, whose political and economic consequences for the region would be deep and long-term.

b) Inter-local competition for state benefits and investments: All localities in the country naturally became competitors to Gaziantep's corporate regime while the political apex of the state and its bureaucracy constituted the site and target of this competition. Here, a locality did not have to be entrepreneurial to be involved in this competition - by putting an organised pressure on their MPs to get state benefits and/or to lobby on their MPs' behalf, to help them capture a ministerial position and thus to gain access to the state resources. Populist concerns, such as re-election, could provide enough motivation for individual MPs to strive to attract state investments and benefits to their own provinces/localities. 
c) Inter-local competition for (regional, domestic and international) markets and interlocal struggle caused by intra-bourgeoisie power relations: The contraction of domestic and regional markets due to the domestic economic crises fueled the competition for these markets, drawing the Anatolian Tigers producing for the same markets into a contest. At this point, we should remember that the the notion of Anatolian Tigers implied a solidarity between the industrialising cities in Anatolia, and thus it was effectively turned into a strong discourse to make the case for Gaziantep's bid for the presidency of different business associations. Nevertheless, the notion of Anatolian Tiger directly refers to a model of local political organisation oriented towards competition. Thus, although the political-economic struggle between the İstanbul-based large scale capital and the industrialists of these Anatolian cities gets the bulk of academic attention in Turkey, the competition between the Anatolian Tigers, like the one between Gaziantep and Kayseri, equally deserves further investigation.

In terms of the relation between Gaziantep and İstanbul, first, we should note that Gaziantep's corporate regime had to take a series of steps to get into a politicaleconomic competition with İstanbul on equal grounds. Gaziantep's bourgeoisie had, first, to get rid of İstanbul's control over the national links with the international and global economy, especially given its special position as the national gateway to the global economy and culture, as recognised by the national governments. In other words, for Gaziantep to be able to truly position itself as a national champion, and to respond to the economic pressure coming from İstanbul - especially from the İstanbul-based finance capital - the local corporate regime had to build direct links to global markets 
and to supra-national, global and international political actors. Building upon this observation, the following points can be made regarding the implications of the territorial representation strategies for the re-scaling process of the capitalist state:

First, an effective economic and political challenge to uneven development requires a de-territorialisation and re-territorialisation of political-economic networks. Cooperation is not a necessity imposed upon localities by historical and geographical closeness, as also discussed above, nor does it necessarily require a network-like approach. Furthermore, such a de/re-territorialisation process, as we see now, is a product of political re-scaling strategies of local actors. This attempt on the side of the GSO and the DSO indicates that the historico-geographical logic of the capitalist accumulation process in Turkey may be challenged more deeply in the coming decade. The actors are now making history by changing the spatial logic of capitalist development in Turkey.

Second, these direct links not only serve to open up new economic channels to the outside world, but also work to enhance the political credibility of Gaziantep with the national state. Moreover, in this context, to promote the cause of Gaziantep as the national champion, the corporate regime leaders are making use of a nationally adopted re-scaling project, accession to the EU, and effectively positioning Gaziantep as a node of communication, experimentation and partnership between the EU and the Turkish state, as well as Southteastern Anatolia. Gaziantep now voluntarily adopts the role of a testing ground for the re-scaling process of the Turkish state's integration with the EU. Here, it is meaningful to remember what Michael Leigh - the then EU commissioner to 
Turkey- said: integration with the EU will not work anywhere if it does not in Gaziantep. In this sense, the corporate regime of Gaziantep is actively contributing to the current and future process of state re-scaling in Turkey.

Relying on the insights of the above analysis, combined with the observations introduced in the foregoing paragraphs, I argue that the rise of cities and regions as significant loci of policy-making, especially in the form local entrepreneurialism, can be understood as the political re-inscription of changes in the balance of power within the bourgeoisie onto the spatial structure of the capitalist state. Thus, local political mobilisations that take the form of entrepreneurialism can be understood as a series of attempts to re-scale the capitalist state from below, i.e, to re-build the state at each and every scale and to determine the logic of articulation of these scales, so as to effect further changes in intra-bourgeois and inter-local balances of power, as well as to secure and institutionalise the advances and gains made in this regard. As we saw throughout the thesis, this broader aim required the employment of a series of well-coordinated and consciously pursued representation strategies that could not be undertaken by the local business associations alone, but had to rely on the political support and backing of other key political-economic actors of the locality. Such a political consensus was also necessary to suppress all other non- or anti- business claims that could harm the supremacy of the local re-scaling agenda, and to keep the local bourgeoisie together behind this project. Nonetheless, the ambitious scope and size of this task brought in a host of problems: 
We noted that the pursuit of scalar strategies of representation could have destabilising consequences for the coherence and future of the urban regime that employed them. Thus, it is important to re-iterate that local agency is not a given thing. It requires time, effective coordination and increased policy-making capacity. Once established, the corporate regimes need continuous protection, which could be possible by sustaining the intra-local power balances (and hierarchies). Here arises the conflictual nature of the enterprise undertaken by the corporate regime of Gaziantep. Criticising the urban regime literature's sole focus on the local scale, I indicated how local coalitions and the corporate regimes were established with extra-local references, in our case explicitly articulating Gaziantep's local political economy with multi-scalar dynamics. This, however, created obstacles to the task of maintaining local balances. It is important to remember here that the re-scaling strategies pursued by the corporate regime stretched the institutional boundaries of local politics to extra-local scales, inviting non-local actors into the field of local politics, including but not restricted to the various organs of the nation state, national political parties, other cities (Anatolian Tigers), national representative organisations of the Turkish bourgeoisie, the European Union, the USA, etc.

A critical source of the possible frictions that could emerge in this regard had to do with the difficulties the corporate regime met in re-scaling strategies, as examplified by the failure to include Gaziantep into the most recent KÖY list of the current (AKP) government. As mentioned, the industrial bourgeoisie in particular began to voice the alternative of distributing state incentives on sectoral grounds when it became clear that 
a territorially framed incentive regime, which would be beneficial to all sectors of Gaziantep's economy and to enterprises of all sizes, was not accessible. Here, the comprehensive - all-inclusive - approach to the defence of "Gaziantep's economic interests" disappeared, supporting a rather selective and exclusionary state benefit regime. Differences in the spatial mobilisation capacity of different firms could foster this difference. As we saw, stronger firms from Gaziantep like the Sanko holding were able to benefit from territorially-defined state schemes, by investing in other GAP provinces included in the KÖY scheme, such as Adıyaman. This created an unpleasant atmosphere within Gaziantep's industrialists when it became clear that Gaziantep would not be included in the KÖY program, and criticisms were directed against the perceived reluctance of certain key actors of the local corporate regime such as the SANKO holding to lobby for the inclusion of Gaziantep to the KÖY regime.

A second problem has recently made its weight felt. It has to do with the fragmentation of Gaziantep's bourgeoisie on political grounds. This is about to become a more serious threat to the political credibility and strength of the corporate regime, or at least to its leadership. The victory of the MÜSIAD candidate in the elections for the presidency of the organised industrial zone, against the candidate of the GSO's administration in 2003, and the capture of the mayor's post by the AKP at the recent local elections, against the experienced and charismatic incumbent mayor of Gaziantep, Celal Doğan, could be interpreted as the signs of this coming challenge. What is important to note here is that the MÜSİAD, as a business association, followed the footsteps of Necmettin Erbakan, whose views regarding the role of Anatolian capital 
and industrialisation were discussed in Chapter 2. The AKP, to a certain extent, is the inheritor of this tradition.

This development indicates that the political changes at the national scale, i.e, the AKP's coming to power at the national level, re-establishing the single party rule in Turkey (thus ending the era of coalition governments), seems to have inserted new tensions into the local politics of Gaziantep, preparing the ground for new challenges to the corporate regime. What was characteristic of this challenge was that the sources and support for this challenge came through more hierarchical channels, as in the case of the determination of the candidate for the mayoralty, and the strategy formation of the local MÜSİAD. Although it has a local branch in Gaziantep, we should emphasise that, as a nationally organised umbrella organisation, the MÜSİAD has a more centralised representation strategy. The views of the local MÜSİAD are formed in strict compliance with the views expressed by the headquarters (this point was also made verbally by one of the officials of the Gaziantep branch, during our informal talk).

The return of single-party rule, apparently, changed the opportunity structure of representation for Gaziantep. The selection process of the MP candidates was determined by the AKP's headquarters, rendering the MPs impotent in defence of Gaziantep's claims for inclusion in the KÖY program. As a political columnist from a local newspaper observed, the AKP's selection of the names did not pay attention to "local balances". Yet, this ignorance of the local balances did not mean that the AKP government did not pay attention to Gaziantep. On the contrary, the frequent visits of different ministers and top bureaucrats to Gaziantep soon after the formation of the new 
government indicated that the AKP had a special interest in Gaziantep. In fact, for the first time in Gaziantep's history, an industrialist became the president of a local party branch (the AKP's Gaziantep branch). The candidate was named by the headquarters, and no other candidate was allowed to enter the local branch elections.

Given these challenges, one could argue that the political configuration of Gaziantep's corporate regime could change, with the introduction of new leaders reshaping the intra-coalition balances. Alternatively, competing local coalitions could be formed pursuing diverging accumulation strategies, one more concentrated on state benefits, more closely articulated to the national political process, another seeking to further promote integration with global markets and production circuits. Here, of course, the previous engagements with the actors from other scales, such as the EU, and the expectation of future benefits from such collaborations established by the current corporate regime could contain the emerging intra-local tensions. A local cohesion of the kind we investigated enhances the bargaining power and credibility of the local economic actors in their direct dealings with the EU. That is why, I argue, there were attempts to re-vitalise the GAGEV, which involved the MÜSİAD too. Of course, this does not preclude the possibility of the stimulation of an intra-local competition around the future stream of benefits coming through the channel of the EU's regional funds. 


\section{BIBLIOGRAPHY}

Books, chapters in edited works, articles in academic journals and conference papers

Abdullah, M.A. 1999. The accessibility of the government-sponsored support programmes for small and medium-sized enterprises in Penang. Cities 16(2): 8392.

Agnew, J. 1997. The dramaturgy of horizons: geographical scale in the 'Reconstruction of Italy' by the new Italian political parties, 1992-95. Political Geography 16(2): 99-121.

Ahmad, F. 1985. Military intervention and the crisis in Turkey. In Turkey in the world capitalist system, edited by H. Ramazanoğlu. Aldershot: Avebury.

Ahmad, F. 1995. Modern Türkiye'nin oluşumu (Translated by Y. Alogan). Sarmal Yayınevi.

Aksoy, Ş. [1995] 2003. Yeni Sağ ve devletin değişimi. In Türkiye'de kamu yönetimi, edited by B. Aykaç, Ş. Durgun and H. Yayman. Ankara: Yargı Yayınevi: 545559.

Allen, J. 2004. The whereabouts of power: politics, government and space. Geographiske Annales 86 B (1): 19-32.

Altıo, M. 1998. 1980 sonrası Türkiye'de sermaye birikimi ve kriz. METU Studies in Development 25(2): 245-274.

Altuğ, S. 1999. Transcription of conference talk. In Esnaf-sanatkar ve küçük işletmeler mesleki kuruluşlarının yeni yönelimleri konferansı. Ankara: TESK, TESAR 29.

Amin A. and N. Thrift. 1999. Institutional issues for the European regions. In The new industrial geography: regions, regulation and institutions, edited by T.J. Barnes and M. S. Gertler. London and NY: Routledge: 292-314. 
Amin, A. 2002. Spatialities of globalisation. Environment and Planning A 34: 385-399.

Amin, A. and K. Robins. 1990. Industial districts and regional development: limits and possibilities. In Industrial districts and interfirm cooperation in Italy, edited by F. Pyko et al. Genova: ILO: 185-219.

Anderson, J. J. 1992. The territorial imperative: pluralism, corporatism and economic crisis. Cambridge: Cambridge University Press.

Aslan, M. 1999. Transcription of conference talk. In Genel teşvik politikalarının değerlendirilmesi ve yeni stratejilerin belirlenmesi, I. Bolum. Ankara: Hazine Mustesarligi-TOBB: 237 - 240.

Aslan, M. 2000. Transcription of meeting minutes. In Merkezi planlamadan kattlımcı planlamaya: GAP Bölge Kalkınma Planı - Bilgilendirme Toplantısı, Çalışma Raporu 2. Gaziantep: T.C. Başbakanlık GAP-BKI: 31-33.

Ataay, F. 2001. Türkiye kapitalizminin mekansal dönüşümü. Praksis 1(2): 53-96.

Austin, J. and A. McCaffrey. 2002. Business leadership coalitions and public-private partnerships in American cities: a business perspective on regime theory. Journal of Urban Affairs 24(1): 35-54.

Avcıŏlu, D. 1975. Türkiye'nin düzeni (İkinci Kitap). Tekin Yayınevi.

Avcıŏlu, D. 1979. Türkiye'nin düzeni (Birinci Kitap). Tekin Yayınevi.

Ay, Y.S. 1997. Report on urban planning and development activities of Greater Gaziantep Municipality. GBB Kültür Dergisi 1997.

Ayata, S. 1987. Kapitalizm ve küçük üreticilik: Türkiye'de hall dokumacıllğg. Ankara: Yurt Yayınları.

Ayata, S. 1999. Bir yerel sanayi odağ1 olarak Gaziantep'de girişimcilik, sanayi kültürü ve diş ekonomik dünya ile ilişkiler. Ekonomide Durum (Fall). Ankara: TÜRK-İŞ Araştırma Merkezi: 85-112.

Aydin, Z. 1986. Underdevelopment and rural structures in Southeastern Turkey. London: Ithaca Press.

Aydinl, E. 2002. Between security and liberalization: decoding Turkey's struggle with the PKK. Security Dialogue 33(2): 209-225. 
Bachtler, J., F. Wishlade and D. Yuill. 2003. Regional policies after 2006: complementarity or conflict? European Policy Research Paper 51 (September 2003), European Policies Research Centre University of Strathclyde.

Bă̆ış, A. 1989. GAP, Southeastern Anatolia Project, The Cradle of Civilization Regenerated. İstanbul: Interbank.

Balme, R. 1998. The French regions as a space for public policy. In Regions in Europe, edited by P. LeGales and C. Lequesne. London and New York: Routledge: $181-$ 198.

Banfield, E.C. 1961. Political influence. New York: The Free Press.

Barkey, H. 1990. The state and the industrialisation crisis in Turkey. San Fransisco: Westview.

Barnes, T.J. 1999. Industrial geography, institutional economics and Innis. In The new industrial geography: regions, regulation and institutions, edited by T.J. Barnes and M. S. Gertler. London and NY: Routledge: 1-22.

Bartlett, W. 2001. SME development policies in different stages of transition. MOCTMOST 11: 197-204.

Başkaya, F. 1991. Paradigmanın iflast: resmi ideolojilerin eleştirisine bir giriş. İstanbul: Doz.

Bateman, M. 2000. Neo-liberalism, SME development and the role of business support centres in the transition economies of Central and Eastern Europe. Small Business Economics 14: 275-298.

Bayırbağ, M.K. 2005. Urban coalitions and re-scaling of the state. Paper presented at the CPSA 2005 Conference. London (Ontario) Canada. 2-4 June 2005.

Bellér-Hann, I. and C. Hann. 2001. Turkish region. Oxford: James Currey.

Bianchi, R. 1984. Interest groups and political development in Turkey. Princeton: Princeton University Press.

Boratav, K. 1990. Inter-class and intra-class relations of distribution under 'structural adjustment': Turkey during the 1980s. In The political economy of Turkey, edited by D. Rodrik and T. Aricanlı. New York: St. Martin's Press.

Boratav, K. 2003. Türkiye İktisat Tarihi: 1908-2002. Ankara: İmge Yayınevi. 
Boratav, K., O. Türel and E. Yeldan. 1995. The Turkish economy in 1981-92: A balance sheet, problems and prospects. METU Studies in Development 22(1): 136.

Bradford, N. 1998. Prospects for associative governance: lessons from Ontario. Politics and Society $26(4)$.

Brautigam, D. 2004. Local entrepreneurship in Southeast Asia and Subsaharan Africa: networks and linkages to the global economy. Draft Paper. $<$ http://www.unu.edu/hq/academic/Pg_area4/Brautigam.html> (2 April 2004)

Brenner, N. 1999. Globalization as reterritorialization: the rescaling of urban governance in the European Union. Urban Studies 36(3): 431-451.

Brenner, N. 2000. The urban question as a scale question: reflections on Henri Lefebvre, urban theory and the politics of scale. IJURR 24(2): 361-378.

Brenner, N. 2001. The limits to scale? Methodological reflections on scalar structuration. Progress in Human Geography 25(4): 591-614.

Brenner, N. 2004. New state spaces: urban governance and the rescaling of statehood. Oxford: Oxford University Press.

Brenner, N. and N. Theodore. 2002. Preface: from the 'new localism' to the spaces of neoliberalism. Antipode 34(3): 341-347.

Bruton, H. 1989. Import substitution. In: Handbook of Development Economics, Edition 1, Volume 2 edited by Hollis Chenery and T.N. Srinivasan. Elsevier: 1601-1644.

Buğra, A. 1990. Turkish holding company as a social institution. Journal of Economics and Administrative Studies 4.

Buğra, A. 1994. Devlet ve İsadamlart. Ankara: İletişim.

Bulut, Y. 2000. Gaziantep'te büyükşehir yönetimine kentsel alt örgütlenmelerin katılımına ilişkin bir analiz. Çağdaş Yerel Yönetimler Dergisi 9(2): 30-61.

Bulutay, T. 1981. Türkiye'nin 1950-1980 dönemindeki iktisadi büyümesi üzerine düşünceler. METU Studies in Development 1981 Special Issue: 493-539. 
Cabus, P. 2001. The meaning of local in a global economy: the 'region's advocacy of local interests' as a necessary component of current global/local theories. European Planning Studies 9 (8): 1011-1029.

Çakmak, C. 1985. Türkiye'de 1950li y1llardaki genel seçimler üzerine bir deneme. METU Studies in Development 12 (3-4): 245-283.

Çarkoğlu, A. and G. Avc1. 2002. An analysis of the electorate from a geographical perspective. In Politics, parties, and elections in Turkey, edited by S. Sayar1 and Y. Esmer. London: Lynne Rienner Publishers.

Carroll, W.K. and M. Shaw. 2001. Consolidating a neoliberal policy bloc in Canada, 1976 to 1996. Canadian Public Policy 27(2): 195-217.

Castells, M. [1972] 1978. City, class and power (translation supervised by Elisabeth Lebas). Macmillan.

Çavdar, T. 2000. Osmanlıların yarım sömürge oluşu. İstanbul: Gelenek.

Celasun, M. 1989. Income distribution and employment aspects of Turkey's post-1980 Adjustment. METU Studies in Development 16(3-4): 1-31.

Ceyhun, F. 1992. Turkey's debt crisis in historical perspective: a critical analysis. METU Studies in Development 19(1): 9-49.

Çilingiroğlu, A. 2003. Transcription of panel talk. In Planlı kalkınma serüveni: 1960'larda Türkiye'de planlama deneyimi. A panel held by Turkish Social Science Association. İstanbul: Bilgi Üniversitesi Yayınları.

Clark, C., J. Green and K. Grenell. 2001. Local regimes: does globalization challenge the growth machine? Policy Studies Review 18(3): 49-62.

Cockburn, C. 1977. The local state. London: Pluto.

Coleman, W.D. and H.J. Jacek. 1989. Capitalists, collective action and regionalism: an introduction. In Regionalism, Business Interests and Public Policy, edited by W.D. Coleman and H.J. Jacek. London: SAGE: 1-12.

Collinge, C. 1999. Self-organisation of society by scale: a spatial reworking of regulation theory. Environment and Planning D: Society and Space 17: 557-574.

Cooke, P. 1997. Regions in a global market: the experiences of Wales and BadenWürttemberg. R.I.P.E 4(2): 349-381. 
Cooke, P. and K. Morgan. 1998. The associational economy: firms, regions and innovation. Oxford: Oxford UP.

Cox, K.R. 1997. Governance, urban regime analysis, and the politics of local economic development. In Reconstructing urban regime theory: regulating urban politics in a global economy, edited by M. Lauria. London: Sage: 99-121.

Cox, K.R. 1998. Spaces of dependence, spaces of engagement and the politics of scale, or: looking for local politics. Political Geography 17(1): 1-23.

Crouch, C. and H. Farrell. 2002. Breaking the path of institutional development? Alternatives to the new determinism. European University Working Papers May 2002.

Dahl, R.A. 1961. Who Governs? New Haven and London: Yale University Press.

Davies, J.S. 2003. Partnerships versus regimes: why regime theory cannot explain urban coalitions. Journal of Urban Affairs 25(3): 253-269.

Delaney, D. and H. Leitner. 1997. The political construction of scale. Political Geography 16(2): 93-97.

Demir, Ö., M. Acar and M. Toprak. 2004. Anatolian Tigers or Islamic capital: prospects and challenges.Middle Eastern Studies 40(6): 166-188.

Dicken, P., P.F. Kelly, K. Olds and H. W-C Yeung. 2001. Chains and networks, territories and scales: towards a relational framework for analysing the global economy. Global Networks 1(2): 89-112.

Digaetano, A. and E. Strom. 2003. Comparative urban governance: an integrated approach. Urban Affairs Review 38(3): 356-395.

Digaetano, A. and P. Lawless. 1999. Urban governance and industrial decline: governing structures and policy agendas in Birmingham and Sheffield, England, and Detroit, Michigan, 1980-1997. Urban Affairs Review 34(4): 546-577.

Dodd, C. H. 1979. Democracy and development in Turkey. The Eothern Press.

Doğruel, F. and S.S. Doğruel. 2003. Türkiye'de bölgesel büyüme farklılıkları ve büyüme. In Küresel düzen: birikim, devlet ve sinıflar, edited by A.H. Köse, F. Şenses and E. Yeldan. İstanbul: İletişim. 
Duncan, S. and M. Goodwin. 1988. The local state and uneven development: behind the local government crisis. Polity Press.

Eberlein, B. 1996. French center-periphery relations and science park development: local policy initiatives and intergovernmental policy making. Governance 9(4): 351-374.

Eisenschitz, A. and J. Gough. 1996. The contradictions of neo-Keynesian local economic strategy. R.I.P.E. 3(3): 434-458.

Eldem, E., D. Goffman and B. Masters. 1999. Introduction. In The Ottoman city between East and West: Aleppo, Izmir and Istanbul, edited by E. Eldem, D. Goffman and B. Masters. Cambridge University Press.

Eralp, A. 1981. Türkiye'de izlenen ithal ikameci kalkınma stratejisi ve yabancı sermaye. METU Studies in Development 1981 Special Issue: 613-633.

Eraydın, A. 2002. Yeni sanayi odakları: yerel kalkınmanın yeniden kavramlaştırılması. Ankara: ODTÜ Mimarlık Fakültesi.

Ercan, F. and Ş. G. Tuna. 2006. İç burjuvazinin gelişimi: 1960'lardan günümüze bakış. In İktisat, Siyaset, Devlet Üzerine Yazılar, Prof. Dr. Kemali Saybaşılı'ya Armağan. İstanbul: Bağlam Yayınevi: 141-173.

Erder, N. 2003. Transcription of panel talk. In Planlı kalkınma serüveni: 1960'larda Türkiye'de planlama deneyimi. A panel held by Turkish Social Science Association. İstanbul: Bilgi Üniversitesi Yayınları.

Ergüder, Ü. 1991. The Motherland Party, 1983-1989. In Political parties and democracy in Turkey, edited by M. Heper and J.M. Landow. London and New York: L. B. Tourins and L.G. Ltd.

Erim, A. 1990. 1973-1980 dönemi belediyeciliği: İzmit örneği. Türk Belediyeciliğinde 60. Yıl (Uluslararası Sempozyum). Ankara: Ankara Metropol Imar AŞ, IULAEMME: 382-394.

Ersoy, M. 1992. Relations between central and local governments in Turkey: a historical perspective. Public Administration and Development 12: 325-341.

Eyüboğlu, D. 2000. Anadolu sanayinde girişimci özellikleri. Ankara: Milli Prodüktivite Merkezi. 
Feldman, M.M.A. 1997. Spatial structures of regulation and urban regimes. In Reconstructing urban regime theory: regulating urban politics in a global economy, edited by M. Lauria. London: Sage: 30-50.

Fransız Kumandanlarından ABADİ. [1921]1959. Türk Verdün'ü Gaziantep: Antep'in dört musaharası. Gaziantep: Gaziantep Kültür Derneği Kitap ve Broşür Yayınları (14). Mürüvvet Matbaasi.

Fukuyama, F. 1995. Trust: the social virtues and the creation of prosperity. New York: Free Press.

Gambetti, Z. 2004. The conflictual (trans)formation of the public sphere in urban space: the case of Diyarbakır. European University Institute Working Paper RSCAS $2004 / 38$.

Geddes, M. 2000. Tackling social exclusion in the European Union? The limits to the new orthodoxy of local partnership. I.J.U.R.R 24(4).

Genieys, W. 1998. Autonomous communities and the state in Spain: the role of intermediary elites. In Regions in Europe, edited by P. LeGales and C. Lequesne. London and New York: Routledge: 166-180.

Genieys, W., X. Ballart and P. Valarie. 2004. From 'great' leaders to building networks: the emergence of a new urban leadership in Southern Europe?" I.J.U.R.R. 28(1): 183-199.

Gertler, M.S. 1992. Flexibility revisited: districts, nation-states, and the forces of production. Transactions of the Institute of British Geographers 17(3): 259-278.

Gertler, M.S. 1999. The production of industrial processes. In The new industrial geography: regions, regulation and institutions, edited by T.J. Barnes and M.S. Gertler. London and NY: Routledge: 225-237.

Goffmann, D. 1999. İzmir: from village to colonial port city. In The Ottoman city between East and West: Aleppo, İzmir and İstanbul, edited by E. Eldem, D. Goffman and B. Masters. Cambridge University Press: 79-134.

Goodwin, M. and J. Painter. 1996. Local governance, the crises of Fordism and the changing geographies of regulation. Transactions of the Institute of British Geographers 21: 635-648.

Grant, W. 1983. Representing capital. In Capital and politics, edited by R. King. London: Routledge (Direct Editions): 69-84. 
Greenwood, J. and R. Webster. 2000. Are EU business associations governable? European Integration online Papers (EIoP) 4(3). $<$ http://eiop.or.at/eiop/texte/2000-003a.htm>

Grote, J.R. 1992 Small firms in the European Community: modes of production, governance and territorial interest representation in Italy and Germany. In Organized Interests and the European Community, edited by J. Greenwood et al. London: SAGE: 119-172.

Gücelioğlu, O. 1994. Küçük ölçekli işletmecilerin KOSGEB'den beklentileri. Ankara: TESK, TESAR-13.

Güler, B.A. 1996. Yeni Sağ ve devletin değişimi: yapısal uyarlama politikaları. Ankara: TODAİE.

Güler, B.A. 2003. Yönetişim: tüm iktidar sermayeye. Praksis 9: 93-116.

Günçe, E. 1981. Türkiye'de planlamanın dünü-bugünü-yarını. METU Studies in Development 1981 Special Issue: 117-132.

Güneş-Ayata, A. 1994. Roots and trends of clientelism in Turkey. In democracy, clientelism, and civil society, edited by L. Roniger and A. Güneş-Ayata. Boulder, Colo.: L. Rienner Publishers: 49-64.

Hadjimichalis, C. 1987. Uneven development and regionalism. London: Croom Helm.

Hadjimichalis, C. and D. Vaiou. 1990. Flexible labour markets and regional development in northern Greece. I.J.U.R.R 14(3): 1-24.

Hamel, P., J-A. Boudreau, R. Keil and B. Jouve. 2006. Comparing metropolitan governance: the cases of Montreal and Toronto. Manuscript.

Hardy, S., M. Hart, L. Albrechts and A. Katos. 1995. An enlarged Europe: regions in competition? Jessica Kingsley Publishers.

Harvey, D. [1989] 2001. From managerialism to entrepreneurialism: the transformation in urban governance in late capitalism (First published in Geographiske Annaler, 1989). Spaces of capital: towards a critical geography. New York: Routledge: Chapter 16. 
Harvey, D. 1985. The urbanization of capital. Baltimore, Maryland: The John Hopkins U.P.

Harvey, D. 1993. Class relations, social justice and the politics of difference. In Place and the politics of identity, edited by M. Keith and S. Pile. London and New York: Routledge: 41-66.

Harvey, D. 1996. Justice, nature and the geography of difference. Oxford.

Harvie, C. 1994. The rise of regional Europe. Routledge, London.

Herod, A. 1997. Labor's spatial praxis and the geography of contract bargaining in the US east coast longshore industry, 1953-89. Political Geography 16(2): 145-169.

Herod, A. and M.W. Wright. 2002a. Introduction: theorising scale. In Geographies of power: placing scale, edited by A. Herod and M.W. Wright. Blackwell Publishing: 17-24.

Herod, A. and M.W. Wright. 2002b. Introduction: scales of praxis. In Geographies of power: placing scale, edited by A. Herod and M.W. Wright. Blackwell Publishing: 217-223.

Hirst, P. 1993. Associational democracy. In Prospects for Democracy, edited by D. Held. Stanford, California: Stanford University Press: 112-135.

Holbrook, J.A. and D.A. Wolfe. eds. 2002. Knowledge, clusters and regional innovation. Montreal: McGill-Queen's University Press.

İlkin, S. 1992. 1980 sonrasında büyük ihracatçıların örgütlenmesi ve Türkiye Dış Ticaret Derneği. METU Studies in Development 19(2): 145-180.

İnsel, A. 1984. Düzen ve kalkınma kıskacında Türkiye. İstanbul: Ayrıntı.

İsbir, E.G. 2003. Kamu kurumu niteliğindeki kuruluşlar: odalar (ticaret, sanayi, esnaf). In Türkiye'de kamu yönetimi, edited by B. Aykaç, Ş. Durgun and H. Yayman. Ankara: Yarg1 Yayınevi: 193-201.

Jenson, J. 1995. Mapping, naming and remembering: globalisation at the end of the twentieth century. R.I.P.E 2(1): 96-116.

Jessop, B. 1990. State Theory. Polity Press. 
Jessop, B. 1997. A neo-Gramscian approach to the regulation of urban regimes: accumulation strategies, hegemonic projects, and governance. In Reconstructing urban regime theory: regulating urban politics in a global economy, edited by $\mathbf{M}$. Lauria. London: Sage: $51-74$.

Jessop, B. 2000. The Crisis of the national spatio-temporal fix and the tendential ecological dominance of globalizing capitalism. I.J.U.R.R 24(2): 323-360.

Jessop, B. 2002. Time and space in the globalization of capital and their implications for state power. Rethinking Marxism 14(1).

Jones, K.T. 1997. Scale as epistemology. Political Geography 17(1): 25-28.

Jones, M. and K. Ward. 2002. Urban policy under capitalism: towards a 'fourth-cut' theory of crisis. SPA Working Paper 50 (October 2002).

Jones, M. and K. Ward. 2002. Urban policy under capitalism: towards a 'Fourth-Cut' theory of crisis. SPA (Spatial Policy Analysis) Working Paper 50. Manchaster: University of Manchaster.

Kalaycıŏlu, E. 2002. Elections and governance. In Politics, parties, and elections in Turkey, edited by S. Sayarı and Y. Esmer. London: Lynne Rienner Publishers.

Karabekir, K. 2001. Iktisat esaslarımı: hatıra ve zabttlartyla 1923 İmir iktisat kongresi, edited by O. Hülagü and Ö.H. Özalp. İstanbul: Emre Yayınları.

Karpat, K.H. 1959. Turkey's politics: the transition to a multi-party system. Princeton and New Jersey: Princeton University Press.

Karpat, K.H. 1991. The Republican People's Party, 1923-1945. In Political parties and democracy in Turkey, edited by M. Heper and J.M. Landow. London and New York: L. B. Tourins and L.G. Ltd.

Kasnakoğlu, H. 1993. GAP Bölgesi'nde 1980 sonrası imalat sanayi gelişmeleri. In GAP ve Sanayi Sempozyumu, 16-18 Ekim 1990 Şanlıurfa, Bildirileri. Ankara: GAP Bölge Kalkınma İdaresi Yayınları: 7-12.

Kaytaz, M. 1990. The role of small and medium industries in development: a case of study of selected sectors in Turkey. Journal of Economics and Administrative Studies 4(1): 53-67. 
Kaytaz, M. 1995. The development and nature of small and medium scale manufacturing enterprises in Turkey. In Turkey: political, social and economic challenges in the 1990s, edited by Ç. Balım, E. Kalaycıoğlu, C. Karataş, G. Winrow and F. Yasamee. Leiden, New York and Köln: E.J. Brill.

Keil, R. 1998. Globalization makes states: perspectives of local governance in the age of the world city. R.I.P.E 5(4): 616-646.

Keleş, R. 2002. Kentleşme politikası $7^{\text {th }}$ Edition. Ankara: İmge.

Kepenek, Y. and N. Yentürk. 1997. Türkiye ekonomisi $9^{\text {th }}$ Edition. İstanbul: Remzi Kitapevi.

Keyder, Ç. 1980. Cumhuriyetin ilk Yıllarında Türk tüccarının 'Milli'leşmesi. METU Studies in Development 1979-1980 Special Issue: 239-255.

Keyder, Ç. 1989. Türkiye'de devlet ve sinıflar, Ankara: İletişim.

Kıliçaslan, Y. and G. Saral. 2005. Locating population dynamics in explaining regional income differentials: inferences for regional policies. Paper prepared for the conference on Middle East and North African Economies: Past Perspectives and Future Challenges, Brussels, June 2-4, 2005.

King, R. 1983. The political practice of local business association. In Capital and politics, edited by R. King. London: Routledge and Kegan Paul: 107-131.

Koçer, N. 2000. Transcription of meeting minutes. In Merkezi planlamadan katılımcı planlamaya: GAP Bölge Kalkınma Planı - Bilgilendirme Toplantısı, Çalışma Raporu 2. Gaziantep: T.C. Başbakanlık GAP-BKI: 33-35.

Köker, L. 1990. Modernleşme, Kemalizm ve demokrasi. İstanbul: İletişim.

Küçük, Y. 1981. Türkiye'de planlama kavramının gelişimi üzerine. METU Studies in Development 1981 Special Issue: 79-115.

Landau, J.M. 1991. Conclusion. In Political parties and democracy in Turkey, edited by M. Heper and J.M. Landow. London and New York: L. B. Tourins and L.G. Ltd.

Langille, D. 1987. The Business Council on national Issues and the Canadian state. Studies in Political Economy 24: 41-85. 
Lanzalaco, L. 1992. Coping with heterogeneity: peak associations of business within and across Western European nations. In Organized interests and the European Community, edited by Justin Greenwood et al. London: SAGE: 173-205.

Laothomatas, A. 1992. Business associations and the new political economy of Thailand. Boulder, San Francisco, Oxford: Westview Press.

Lauria, M. 1997. Introduction: reconstructing urban regime theory. In Reconstructing urban regime theory: regulating urban politics in a global economy, edited by $\mathrm{M}$. Lauria. London: Sage: 1-10.

Lauria, M. ed. 1997. Reconstructing urban regime theory: regulating urban politics in a global economy. London: SAGE.

Lefebvre, H. 1991. The production of space (Translated by Donald Nicholson-Smith). Oxford: Basil Blackwell.

LeGales, P. and C. Lequesne. eds. 1998. Regions in Europe. London and New York: Routledge.

Lehmkul, D. 2000. Under stress: Europeanisation and trade associations in the member states. European Integration Online Papers (EIoP) 4(14) $<$ http://eiop.or.at/eiop/texte/2000-014a.htm>

Leibowitz, J. 2003. Institutional barriers to associative city-region governance: the politics of institution-building and economic governance in 'Canada's Technology Triangle'. Urban Studies 40(13): 2613-2642.

Lemarchand, R. and K. Legg. 1972. Political clientelism and development: a preliminary analysis. Comparative Politics 4(2): 149-178.

Leo, C. 1997. "City Politics in an Era of Globalization" in M. Lauria (ed.) Reconstructing Urban Regime Theory, Regulating Urban Politics in a Global Economy, London: Sage, 77 - 98.

Levi, A. 1991. The Justice Party, 1961-1980. In Political parties and democracy in Turkey, edited by M. Heper and J.M. Landow. London and New York: L. B. Tourins and L.G. Ltd.

Lewis, B. 2002. The emergence of modern Turkey $3^{\text {rd }}$ Edition. New York and London: Oxford University Press. 
Logan, J.R. and H.L. Molotch. 1990. Urban fortunes: the political economy of place. Berkeley, Los Angeles, California: University of California Press.

Loveman, G. and W. Sengenberger. 1990. Introduction: economic and social reorganisation in the small and medium-sized enterprise sector. In The reemergence of small enterprises: industrial restructuring in industrialised countries, edited by W. Sengenberger et al. Genova: ILO.

Lovering, J. 1999. Theory led by policy: the inadequacies of 'the New Regionalism' (ilustrated in the case of Wales). I.J.U.R.R 23: 379-395.

Lowndes, V. and D. Wilson. 2001. Social capital and local governance: exploring the institutional design variable. Political Studies 49: 629-647.

MacLeod, G. 1999. Place, politics and scale dependence: exploring the structuration of Euro-regionalism. European Urban and Regional Studies 6(3): 231-253.

MacLeod, G. 2001. New regionalism reconsidered: globalisation and the remaking of political economic space. I.J.U.R.R 25(4): 804-829.

MacLeod, G. and M. Goodwin. 1999. Space, scale and state strategy: rethinking urban and regional governance. Progress in Human Geography 23(4): 503-527.

Mahon, R. 1980. Regulatory agencies: captive agents or hegemonic apparatuses (First published in Studies in Political Economy 1(1)). In Class, state, ideology and change: Marxist perspectives on Canada, edited by J.P. Grayson. Toronto: Holt, Rinehart \& Win- stun: 154-168.

Mahon, R. 1984. The politics of industrial restructuring: Canadian textiles. Toronto, Buffalo, London: University of Toronto Press.

Mahon, R. 2003. Constructing a new urban citizenship? Childcare politics in Toronto in the 1970s and 1980s. Unpublished Paper Presented at Workshop on "Women and Paid Labour After World War 2, McGill Institute of Studies of Canada and McGill Centre for Research and Teaching on Women, 22 March 2003.

Mahon, R. 2005. Rescaling social reproduction: childcare in Toronto/Canada and Stockholm/Sweden. Manuscript.

Mahon, R. and R. Keil. 2006. The Political Economy of Scale: An Introduction. Manuscript. 
Mardin, S.. 1980. Turkey: the transformation of an economic code. In The political economy of income distribution in Turkey, edited by E. Özbudun and A. Ulusan. New York and London: Holmes and Meier Publishers.

Mardin, Ş. 1990. Türkiye'de toplum ve siyaset. İstanbul: İletişim.

Marston, S.A. 2000. The social construction of scale. Progress in Human Geography 24(2): 219-242.

Marston, S.A. and N. Smith. 2001. States, scales and households: limits to scale thinking? A response to Brenner. Progress in Human Geography 25(4): 615-619.

Martin, D., E. McCann and M. Purcell. 2003. Space, scale, governance, and representation: contemporary geographical perspectives on urban politics and policy. Journal of Urban Affairs 25(2): 113-121.

Massey, D. 1993. Politics and space/time. In Place and the politics of identity, edited by M. Keith and S. Pile. London and New York: Routledge: 141-161.

Masson, D. 2005. Constructing scale/contesting scale: Women's Movement and rescaling politics in Québec. Paper presented at the Studies in Political Economy Annual Conference Towards a Political Economy of Scale, February 3-5, 2005, York University, Toronto.

Masson, D. 2006. Engaging with the politics of downward rescaling: representing women in regional development policymaking in Québec (Canada). Geojournal 65(3-4): 1-13.

Masters, B. 1999. Aleppo: The Ottoman Empire's carawan city. In The Ottoman city between East and West: Aleppo, Izmir and Istanbul, edited by E. Eldem, D. Goffman and B. Masters. Cambridge University Press: 17-78.

Mayer, M. 1995. Urban governance in the post-Fordist city. In Managing cities: the new urban context, edited by P. Healey et al. John Wiley and Sons: 231-249.

McCann, E. 2003. Framing space and time in the city: urban policy and the politics of spatial and temporal scale. Journal of Urban Affairs 25(2): 159-178.

McDowell, L. 2001. Linking scales: or how research about gender and organizations raises new issues for economic geography. Journal of Economic Geography 1: $227-250$. 
McGuirk, P.M. 2003. Producing the capacity to govern in global Sydney: a multiscaled account. Journal of Urban Affairs 25(2): 201-223.

McMahon, R.G.P. 2001. Deriving an empirical development taxonomy for manifacturing SMEs using data from Australia's business longitudinal survey. Small Business Economics 17: 197-212.

Miller, B. 1994. Political empowerment, local-central state relations, and geographically shifting political opportunity structures. Political Geography 13(5): 393-406.

Miller, B. 1997. Political action and the geography of defense investment: geographical scale and representation of the Massachusetts Miracle. Political Geography 16(2): 171-185.

Müftüoğlu, T. ed. 1992. Mevzuatın küçük işletmelere maliyeti. TES-AR Tartışma Notları No: 2. Ankara: TESK.

Mutlu, S. 1990. Bölgesel iç ticaret hadleri, kırsal refah ve iç göçler. Journal of Economics and Administrative Studies 4(1): 69-87.

Mutlu, S. 1993. GAP Bölgesi'nde sanayi ve gerekli teşvik sistemi. In GAP ve Sanayi Sempozyumu, 16-18 Ekim 1990 Şanlıurfa, Bildirileri. Ankara: GAP Bölge Kalkınma İdaresi Yayınları: 13-16.

Mutlu, S. 2001. Economic bases of ethnic separatism in Turkey: an evaluation of claims and counterclaims. Middle Eastern Studies 37(4):101-135.

Ohmae, K. 1995. The end of the nation state: the rise of regional economies. The Free Press.

Okçuoğlu, İ. 1996. Türkiye'de kapitalizmin gelişmesi (Birinci kitap): iç pazarın oluşma süreci. İstanbul: Ceylan.

Okçuoğlu, İ. 1999. Türkiye'de kapitalizmin gelişmesi (İkinci kitap): iç pazarın oluşma süreci (1923-1950). İstanbul: Ceylan.

Okçuoğlu, İ. 2001. Türkiye'de kapitalizmin gelişmesi (Üçüncü kitap): iç pazarın oluşma süreci (1950-1991). İstanbul: Ceylan.

Öktem, K. 2004. Incorporating the time and space of the ethnic 'other': nationalism and space in Southeast Turkey in the nineteenth and twentieth centuries. Nations and Nationalism 10(4): 559-578. 
Öncii, A. 1980. Chambers of industry in Turkey: an inquiry into state-industry relations as a distributive domain. In The political economy of income distribution in Turkey, edited by E. Özbudun and A. Ulusan. New York and London: Holmes and Meier Publishers.

Önder, İ. 2003. Kapitalist ilişkiler bağlamında ve Türkiye'de devletin yeri ve işlevi. In Küresel düzen: birikim, devlet ve sinıflar, edited by A.H. Köse, F. Şenses and $\mathrm{E}$. Yeldan. İstanbul: İletişim.

Öngen, T. 2003. 'Yeni Liberal' dönüşüm projesi ve Türkiye deneyimi. In Küresel dïzen: birikim, devlet ve sintflar, edited by A.H. Köse, F. Şenses and E. Yeldan. İstanbul: İletişim: 161-189.

Öniş, Z. 1995. The political economy of export-oriented industrialisation in Turkey. In Turkey: political, social and economic challenges in the 1990s, edited by Ç. Balım, E. Kalaycıoğlu, C. Karataş, G. Winrow and F. Yasamee. Leiden, New York and Köln: E.J. Brill.

Öniş, Z. 1997. The political economy of Islamic resurgence in Turkey: the rise of the Welfare Party in perspective. Third World Quarterly 18(4): 743-766.

Özbudun, E. 1976. Social change and political participation in Turkey. New Jersey: Princeton University Press.

Özbudun, E. 1980. Income distribution as an issue in Turkish politics. In The political economy of income distribution in Turkey, edited by E. Özbudun and A. Ulusan. New York and London: Holmes and Meier Publishers.

Özcan, G.B. 2000. Local economic development, decentralisation and consensus building in Turkey. Progress in Planning 54(4): 199-278.

Özsabuncuoğlu, İ.H., A. Özsağır and A.A. Uğur. 1999. Son dönem Gaziantep ekonomisi. In Cumhuriyetin 75. yllina armağan, edited by Y. Küçükdağ. Gaziantep: Gaziantep Üniversitesi Vakfı Kültür Yayınları 6: 31-46.

Özsağır, A. 1999. Cumhuriyetin 75. yılında Gaziantep sanayii. In Cumhuriyetin 75. yılına armağan, edited by Y. Küçüikdağ. Gaziantep: Gaziantep Üniversitesi Vakfı Kültür Yayınları 6: 63-81.

Paasi, A. 2004. Place and region: looking through the prism of scale. Progress in Human Geography 28(4): 536-546. 
Painter, J. 1998. Entrepreneurs are made, not born: learning and urban regimes in the production of entrepreneurial cities. In The entrepreneurial city: geographies of politics, regime and representation, edited by T. Hall and P. Hubbard. John Williams and Sons: 259-272.

Paksoy, M. 2002. Güneydoğu Anadolu Projesi (GAP) bölgesinde faaliyet gösteren sanayi işletmelerinde üst düzey yöneticilerin profilleri. Şanlıurfa: T.C. Başbakanlık, GAP-BKİ Başkanlığı.

Peck, J. 2002. Political economies of scale: fast policy, interscalar relations, and neoliberal workfare. Economic Goegraphy 78(3): 331-360.

Peck, J. and A. Tickell. 2002. Neoliberalising Space. Antipode 34(3): 380-404.

Peet, R. 1998. Modern geographical thought. Malden, MA: Blackwell Publishers.

Pekdoğan, C. 1999. Gaziantep Ticaret Odasının 100 Y1lı: 1898-1998. Gaziantep: GTO Publications.

Pierre, J. 2005. Comparative urban governance: uncovering complex causalities. Urban Affairs Review 40(4): 446 - 462.

Piore, M.J. 1990. Three responses to Ash Amin and Kevin Robins: M. J. Piore replies. In Industrial districts and interfirm cooperation in Italy, edited by F. Pyko et al. Genova: ILO: 225-227.

Piore, M.J. and S.F. Sabel. 1984. The second industrial divide: possibilities for prosperity. Basicbooks.

Polanyi, K. [1957] 1992. The economy as instituted process. In The sociology of economic life, edited by M. Granovetter and R. Swedberg. Boulder CO: Westview Press: $53-81$.

Poulantzas, N. 1978. State, power, socialism. Verso.

Purcell, M. 2005. Urban democracy and the local trap. Paper presented at the Studies in Political Economy Annual Conference Towards a Political Economy of Scale, February 3-5, 2005, York University, Toronto.

Putnam, R. 1993. Making democracy work: civic traditions in modern Italy. Princeton: Princeton U.P. 
Putnam, R. 2000. Bowling alone: the collapse and revival of American community. New York: Simon and Schuster.

Ramazanoğlu, H. 1985a. Introduction. In Turkey in the world capitalist system, edited by H. Ramazanoğlu. Aldershot: Avebury.

Ramazanoğlu, H. 1985b. A political analysis of the emergence of Turkish capitalism, 1839-1950. In Turkey in the world capitalist system, edited by H. Ramazanoğlu. Aldershot: Avebury.

Rhodes, R.A.W. 2000. The governance narrative: key findings and lessons from the Erc's Whitehall Programme. Public Administration 78(2): 345-363.

Rousseau, J. 2000. The new political scales of citizenship in a global era: the politics of hydroelectric development in the James Bay Region. Unpublished DoctoralThesis. Ottawa: Carleton University (Canada).

Sabel, C.F. 1990. Three Responses to Ash Amin and Kevin Robins: C. F. Sabel Replies. In Industrial districts and interfirm cooperation in Italy, edited by F. Pyko et al. Genova: ILO: 220-224.

Sack, D. 1986. Human territoriality: its theory and history. Cambridge: Cambridge University Press.

Sariaslan, H. 1999. Transcription of conference talk. In Esnaf-sanatkar ve küçük işletmeler mesleki kuruluşlarının yeni yönelimleri konferanst. Ankara: TESK, TESAR 29: 34-40.

Sayarı, S. 2002. The changing party system. In Politics, parties, and elections in Turkey, edited by S. Sayarı and Y. Esmer. London: Lynne Rienner Publishers.

Şaylan, G. 1981. Planlama ve bürokrasi. METU Studies in Development 1981 Special Issue: 183-205.

Schaede, U. 2000. Cooperative capitalism: self-regulation, trade associations, and the antimonopoly law in Japan. Oxford, New York: Oxford University Press.

Schmitter, P.C. 1974. Still the century of corporatism? The Review of Politics 36(1): 85131.

Schmitter, P.C. and L. Lanzalaco. 1989. Regions and the organization of business interests. In Regionalism, business interests and public policy, edited by W.D. Coleman and H.J. Jacek. London: SAGE: 201-230. 
Schmitter, P.C. and J.R. Grote. 1997. The corporatist sisyphus: past, present and future. EUI Working Paper SPS 97/4.

Şenesen, H.N. 1999. Kişi başına gayrisafi yurtiçi ürün değerlerinin illere ve bölgelere göre dağılımı. Ekonomide Durum Fall 1999. Ankara: TÜRK-İŞ Araştırma Merkezi: 136-142.

Şengül, H.T. 1999. Siyaset ve mekansal ölçek sorunu: yerelci stratejilerin bir eleştirisi. In Küreselleşme: emperyalizm, yerellik ve iş̧i sınıfi, edited by A. Tonak. Ankara: İmge.

Şengül, H.T. 2001. Kentsel çelişki ve siyaset. İstanbul: WALD.

Şenses, F. 1990. An assesment of the pattern of Turkish manufactured export growth in the 1980s and its prospects. In The political economy of Turkey, edited by D. Rodrik and T. Arıcanlı. New York: St. Martin's Press.

Şenses, F. and A. Kurım. 1991. Türkiye'de 1980 sonrası ekonomik politikalar sanayileşme etkileşimi ve sanayiin yeniden yapılanma gerekliliği. METU Studies in Development 18(1-2): 111-141.

Şerbetçi, M.K. 1993. Güneydoğu Anadolu Bölgesi'nin ekonomik kalkınmasında Gaziantep sanayinin yeri. In GAP ve Sanayi Sempozyumu, 16-18 Ekim 1990 Şanlıurfa, Bildirileri. Ankara: GAP Bölge Kalkınma İdaresi Yayınları.

Şerbetçi, M.K. 1997. Opinion piece. GBB Kültür Dergisi 1997.

Silva, E. and F. Durand. 1998. Organized business and politics in Latin America. In Organized business, economic change, and democracy in Latin America, edited by E. Silva and F. Durand. University of Miami: North-South Center Press: 1-50.

Şimşek, S. 2004. The transformation of civil society in Turkey: from quantity to quality. Turkish Studies 5(3): 46-74.

Skocpol, T. 1986. Rediscovering the state: strategies of analysis in current Research. In Bringing the state back in, edited by P.B. Evans et al. Cambridge: Cambridge University Press: 3-37.

Smith, N. 1991. Uneven development. Blackwell: Oxford.

Smith, N. 1992. Geography, difference and the politics of scale. In Post-Modernism and the Social Sciences, edited by J. Doherty et al. NewYork: St. Martin's Press: 5779. 
Smith, N. 1996. Spaces of vulnerability: the space of flows and the politics of scale. Critique of Anthropology 16(1): 63-77.

Smouts, M-C. 1998. The Region as the new imagined community? In Regions in Europe, edited by P. LeGales and C. Lequesne. London and New York: Routledge: $30-38$.

Smyrl, M.E. 1997. Does European Community regional policy empower the regions? Governance 10(3): 287-309.

Soja, E. 1985. Regions in context: spatiality, periodicity, and the historical geography of the regional question. Environment and Planning D: Society and Space 3: 175190.

Sönmez, A. 2003. Transcription of panel talk. In Planlı kalkınma serüveni: 1960'larda Türkiye'de planlama deneyimi. A panel held by Turkish Social Science Association. İstanbul: Bilgi Üniversitesi Yayınları.

Sönmez, M. 1987. Türkiye'de holdingler. Ankara: Arkadaş.

Sönmez, M. 1999. Gelir dağılımında bir yanımız Afrika, bir yanımız Avrupa. Ekonomide Durum Fall 1999. Ankara: TÜRK-İŞ Araştırma Merkezi: 143-154.

Soskice, D. 1999. Divergent production regimes: coordinated and uncoordinated market economies in the 1980 s and 1990s. In Continuity and change in contemporary capitalism, edited by H. Kitschelt et al. CUP: 101-134.

Stone, C.N. 2004. Power, reform, and urban regime analysis. Research paper, <http://www.bsos.umd.edu/gvpt/stone/power2.html $>$

Stone, C.N. 2005. Looking back to look forward: reflections on urban regime analysis. Urban Affairs Review 40(3): 309-341.

Storper, M. 1990. Three Responses to Ash Amin and Kevin Robins: M. Storper Replies. In Industrial Districts and Interfirm Cooperation in Italy, F. Pyko et al. (eds) Genova: ILO, 228-237.

Storper, M. 1999. The resurgence of regional economics. In The new industrial geography: regions, regulation and institutions, edited by T.J. Barnes and M.S. Gertler. London and NY: Routledge: 23-53. 
Storper, M. and R. Walker. 1989. The capitalist imperative: territory, technology, and industrial growth. Oxford: Blackwell.

Streeck, W. 1989. The territorial organization of interests and the logics of associative action: the case of Handwerk organization in West Germany. Regionalism, business interests and public policy, edited by W.D. Coleman and H.J. Jacek. London: SAGE: 59-94.

Suğur, N. 1997. Growth potential of small firms in Turkey: a sociological study of the OSTIM industrial estate in Ankara. METU Studies in Development 24(1): 109128.

Swyngedouw, E. 1997a. Neither global nor local: 'glocalization' and the politics of scale. In Spaces of globalization: reasserting the power of the local, edited by K.R. Cox. New York, London: The Guilford Press: 137-166.

Swyngedouw, E. 1997b. Excluding the other: the production of scale and scaled politics. In Geographies of Economies, edited by R. Lee and J. Wills. London: Arnold:167-176.

Tachau, F. 1991. The Republican People's Party, 1945-1980. In Political parties and democracy in Turkey, edited by M. Heper and J.M. Landow. London and New York: L. B. Tourins and L.G. Ltd.

Taşkın, F. and E. Yeldan. 1996. Export expansion, capital accumulation and distribution in Turkish manufacturing, 1980-9. In The economy of Turkey since liberalisation, edited by S. Togan and V.N. Balasubramanyan. MacMillan: 155-176.

Taylor, L. 1990. Turkish experience: summary and comparative notes. In The political economy of Turkey, edited by D. Rodrik and T. Aricanlı. New York: St. Martin's Press.

Taylor, P.J. 1982. A materialist framework for political geography. Transactions of Institute of British Geographers 7: 15-34.

Tekeli, İ. 1980. 2. Dünya Savaşı sırasında hazırlanan 'Savaş Sonrası Kalkınma Programları. METU Studies in Development 1979-1980 Special Issue: 289-327.

Tekeli, İ. 1981. Dört plan döneminde bölgesel politikalar ve ekonomik büyümenin mekansal farklılaşması. METU Studies in Development 1981 Special Issue: 369390.

Tekeli, İ. 1992. Belediyecilik yazıları. İstanbul: IULA. 
Tekeli, İ. and S. İlkin. 1982. Uygulamaya geçerken Türkiye'de devletçiliğin oluşumu. Ankara: ODTÜ.

Turan, İ. [1999] 2003. Türk bürokrasisinde süreklilik ve değişim. In Türkiye'de kamu yönetimi, edited by B. Aykaç, Ş. Durgun and H. Yayman. Ankara: Yarg1 Yayınevi: 121-144.

Turgut, M. 1995. GAP'ın sahipleri. İstanbul: Boğaziçi Yayınları.

Üzel, S. 1946. Gaziantep savaşı ve Kılıç Ali. Kayseri: Sümer Matbaası.

Valler, D., A. Wood and P. North. 2000. Local governance and local business interests: a critical review. Progress in Human Geography 24(3): 409-428.

Ward, K. and A.E.G. Jonas. 2004. Competitive city-regionalism as a politics of space: a critical reinterpretation of the new regionalism. Environment and Planning A 36: 2119-2139.

Weiss, L. 1988. Creating capitalism: the state and small business since 1945. Basil Blackwell.

Weiss, L. 1998. The myth of the powerless state. Ithaca, New York: Cornell University Press.

Whatmore, S. and L. Thorne. 1997. Nourishing networks: alternative geographies of food. In Globalising food: agrarian questions and global restructuring, edited by D. Goodman et al. London and New York: Routledge: 287-304.

Williamson, P.J. 1989. Corporatism in perspective: an introductory guide to corporatist theory. London: SAGE.

Wolfe, D.A. 1997. The emergence of the region state. In The nation state in a global/information era: policy challenges, edited by T.J. Courchene. Kingston (John Deutsch Institute for the Study of Economic Policy): Queen's U: 205-240.

Wolfe, D.A. 2002. Social capital and cluster development in learning regions. In Knowledge, clusters and regional innovation, edited by J.A. Holbrook and D.A. Wolfe. Montreal: McGill-Queen's University Press.

Wolfe, D.A. and M.S. Gertler. 2001. Globalization and economic restructuring in Ontario: from industrial heartland to learning Region? European Planning Studies 9(5). 
Wolfe, D.A. and M.S. Gertler. 2002. Innovation and social learning: an introduction. In Innovation and social learning: institutional adaptation in an era of technological change, edited by M.S. Gertler and D.A. Wolfe. Basingstoke: Palgrave: 1-24.

Wood, S. 2000. Reconciling production and protection: the varieties of capitalism approach to the study of welfare states, Paper presented for the conference 'European Welfare States: Domestic and International Challenges', Oct. 2000.

Yalkın, H. 1999. Transcription of conference talk. In Esnaf-sanatkar ve küçük işletmeler mesleki kuruluşlarının yeni yönelimleri konferansı. Ankara: TESK, TESAR 29: 40-47.

Yalman, G.L. 2002. The Turkish state and bourgeoisie in historical perspective: a relativist paradigm on a panoply of hegemonic projects. In The politics of permanent crisis: class, ideology and state in Turkey, edited by N. Balkan and S. Savran. New York: Nova Science Publishers.

Yaşinok, K. 1999. Transcription of conference talk. In Genel teşvik politikalarının değerlendirilmesi ve yeni stratejilerin belirlenmesi, I. Bolum. Ankara: Hazine Mustesarligi-TOBB: 96-102.

Yeldan, E. 2001. Küreselleşme sürecinde Türkiye ekonomisi: bölüşüm, birikim ve büyüme. İstanbul: İletişim.

Yeldan, E. 2002. On the IMF-directed disinflation program in Turkey: a program for stabilisation and austerity or a recipe for impoverishment and financial chaos? In The ravages of neo-liberalism: economy, society and gender in Turkey, edited by N. Balkan and S. Savran. New York: Nova Science Publishers.

Zürcher, E.J. 1993. Turkey: a modern history. London and New York: I. B. Tauris and Co.

\section{Institutional authors, reports, and unpublished data}

DPT. 2002. Denizli ve Gaziantep illeri imalat sanayinin yapisı. Ankara: DPT-2650.

GAP-BKİ. 2001. GAP report on year 2000 activities. Ankara: GAP-BKİ.

Gaziantep Halk Evi. 1935. Gaziantep Halk Evi Broşürü. Gaziantep: Halk Fırkası Matbaasi. 
GSO. 2000. GSO vision document for Gaziantep in 2001.

GSO. 2003 Unpublished data from the local industry survey. Obtained from Kürşat Göncü - General Secretary of GSO.

GTO. 2000. Gaziantep by figures. Gaziantep: GTO Publications.

GTO. 2001. Gaziantep by figures. Gaziantep: GTO Publications.

GTO. 2002. Gaziantep by figures. Gaziantep: GTO Publications.

GTO. 2003. Gaziantep by figures. Gaziantep: GTO Publications.

GTO. 2005. Gaziantep by figures. Gaziantep: GTO Publications.

GTZ. 1998. Gaziantep sanayi odast strateji özet raporu, 10 August 1998 (obtained from the GSO, information and media office.

Hjorth, S. 2002. Policy document (summary on the Gaziantep Business Centre Project).

MPM. 1998. Gaziantep, verimliliği artırma projesi. Ankara: MPM.

Say1n, M. 2003. Gap-Gidem Phase 2: Project Initiation/Start Report (and Project Presentation).

T.C. D1ş Ticaret Müsteşarlığı, Teşvik Uygulama Genel Müdürlüğü, Denetim Müdürlügü. 2003. Printed data sheet on export incentives.

T.C. Gaziantep Valiliği, İl Sanayi ve Ticaret Müdürlüğü. 1998. Gaziantep ili 1998 yılı ekonomik ve ticari durumu hakkında raporu. Gaziantep: T.C. Gaziantep Valiliği.

T.C. Gaziantep Valiliği, İl Sanayi ve Ticaret Müdürlüğü. 2000. Gaziantep ili 2000 yılı ekonomik ve ticari durumu hakkında raporu. Gaziantep: T.C. Gaziantep Valiliği.

T.C. Gaziantep Valiliği, İl Sanayi ve Ticaret Müdürlüğü. 2001. Gaziantep ili 2001 yılı ekonomik ve ticari durumu hakkında raporu. Gaziantep: T.C. Gaziantep Valiliği.

TSKB/Priva Danışmanlık Hizmetleri A.Ş. 1991. GAP ekonomik kalkinma model etüdü (Taslak rapor). Ankara: TSKB. 


\section{Newspapers, news agencies and non-academic journals}

"Anatolian Agency": National public news agency, Turkey.

“Değişim”: The GSO's official journal, Gaziantep.

“Gaziantep 27”: Local newspaper, Gaziantep.

“Gaziantep’te Sabah": Local newspaper, Gaziantep.

“GBB Kültür Dergisi”: The Greater Gaziantep Municipality's official journal, Gaziantep.

“Genç Çizgi”: The GAGİAD’s official journal, Gaziantep.

“Görüş": The TÜSİAD's official journal, İstanbul.

"Gözlem": Regional newspaper (Aegean Region), İzmir.

"Hürriyet": National newspaper, İstanbul.

"Metropol": Local newspaper, Gaziantep.

"Milliyet": National newspaper, Turkey.

“Oluşum”: Local newspaper, Gaziantep.

“Referans Gazetesi”: National newspaper, İstanbul.

"Yorum": Local journal, Gaziantep.

\section{World wide websites}

DEİK: <www.deik.org.tr>

DİE: <www.die.gov.tr>

DPT: <www.dpt.gov.tr>

DSO: <www.dso.org.tr > 
EGSD: <www.egsd.org.tr>

GAGIAD: <www.gagiad.org.tr>

GAP-BKI: <www.gap.gov.tr>

GAPGIAD: <www.gapgiad.org.tr>

GSO: <www.gso.org.tr>

GTO: <www.gto.org.tr>

KOSGEB: <www.kosgeb.gov.tr>

Local news website: <www.sirinnar.net>

The Governor's Office of Gaziantep: <www.gaziantep.gov.tr>

The Greater Gaziantep Municipality: <www.gaziantep-bld.gov.tr>

The Prime Minister's Office of the Republic of Turkey: <www.basbakanlik.gov.tr>

The Turkish Parliament: <www.tbmm.gov.tr>

The Undersecretariat of Foreign Trade of the Republic of Turkey: <www.dtm.gov.tr>

TÜSİAD: <www.tusiad.org.tr>

\section{Interviewee List}

“Akşin, Bülent": Industrialist; President of the Esnaf Chamber of Shoe Producers of Gaziantep. (2004, Gaziantep)

"Aktaş, Nurettin": MP, Gaziantep (AKP); Businessman; Ex-President of the Southeastern Exporters' Union (founding President). (2004, Ankara)

"Atay, Aynur": General Secretary of the GAGEV; Ex-policy specialist of the GAPGiDEM centre in Gaziantep. (2004, Gaziantep)

“Ateş, Abdülkadir”: MP, Gaziantep (CHP); Ex-minister of tourism. (2004, Ankara) 
"Ay, Yavuz Selim": City planner; Director of the urban planning and development department of the Greater Gaziantep Municipality. (2004, Gaziantep)

"Ayata, Sencer": Professor Dr., Department of Sociology, Middle East Technical University. (2004, Ankara)

"Balat, Muharrem": Industrialist; President of the Southeast Thread Exporters' Union. (2004, Gaziantep)

"Bozkurt, Mecit": Local politician (president of the local branch of the EMEP - the Labour's Party). (2004, Gaziantep)

"Burnukara, Ali": Industrialist; Ex-member of the GTSO assembly. (2004, Gaziantep)

"Çevik, Hasan": Ex-deputy General Secretary of the Greater Gaziantep Municipality (Doğan government). (2004, Gaziantep)

"Doğan, Hamit": Policy specialist, the EU Business Centre in Gaziantep; Ex-policy specialist of the GAP-GIDEM centre in Gaziantep. (2004, Gaziantep)

"Ekici, Akif": Ex-president of Gaziantep OSB. (2004, Gaziantep)

"Ekinci, Mustafa" (group interview): Industrialist; Vice-President of the Esnaf Chamber of Furniture Producers of Gaziantep. (2004, Gaziantep)

"Ercan, Turgut": Industrialist; Member of the GAGIAD management board. (2004, Gaziantep)

"Geylani, Mustafa": Ex-president of the GTO; ex-president of the GTO assembly. (2004, Gaziantep)

"Göncü, Kürşat”: General Secretary of the GSO. (2004, Gaziantep)

"Güloğlu, Ebru": Director of the USA Information office (under the GSO). (2004, Gaziantep)

"Güzel, Asım": Ex-president of the local branch of national chamber of architects; Candidate for Mayorship of the Greater Gaziantep Municipality at the local elections of 1999. (2004, Gaziantep)

"Hjorth, Soren": Policy specialist (founding coordinator of the EU Business Centre in Gaziantep). (2004, Gaziantep) 
"Katırl, Vakkas": Vice-president of the GESOB.

"Kepkep, Zihni": President of the Gaziantep Chamber of Agriculture; President of the Şahinbey Branch of CHP. (2004, Gaziantep)

"Kinacigil, Coşkun": General Secretary of the GESOB. (2004, Gaziantep)

"Konukoğlu, Yalçın": Industrialist; President of the Esnaf Chamber of Carpet Producers of Gaziantep. (2004, Gaziantep)

"Öğüt, Figen": Deputy-General Secretary of the GTO; Director of the EU Information office. (2004, Gaziantep)

“Ölçal, Mesut”: General Secretary of the GTO. (2004, Gaziantep)

"Sayın, Meral": Policy specialist, UNDP; Coordinator of the GAP-GIDEM (phase 2). (2004, Ankara)

"Tuzcu, Aykut": Owner of the local newspaper, Gaziantep'te Sabah; ex-member of the GSO assembly (founding member). (2004, Gaziantep)

"Ylldırım, Mahmut" (group interview): Industrialist; President of the Esnaf Chamber of Socks Producers and Weawers of Gaziantep. (2004, Gaziantep) 